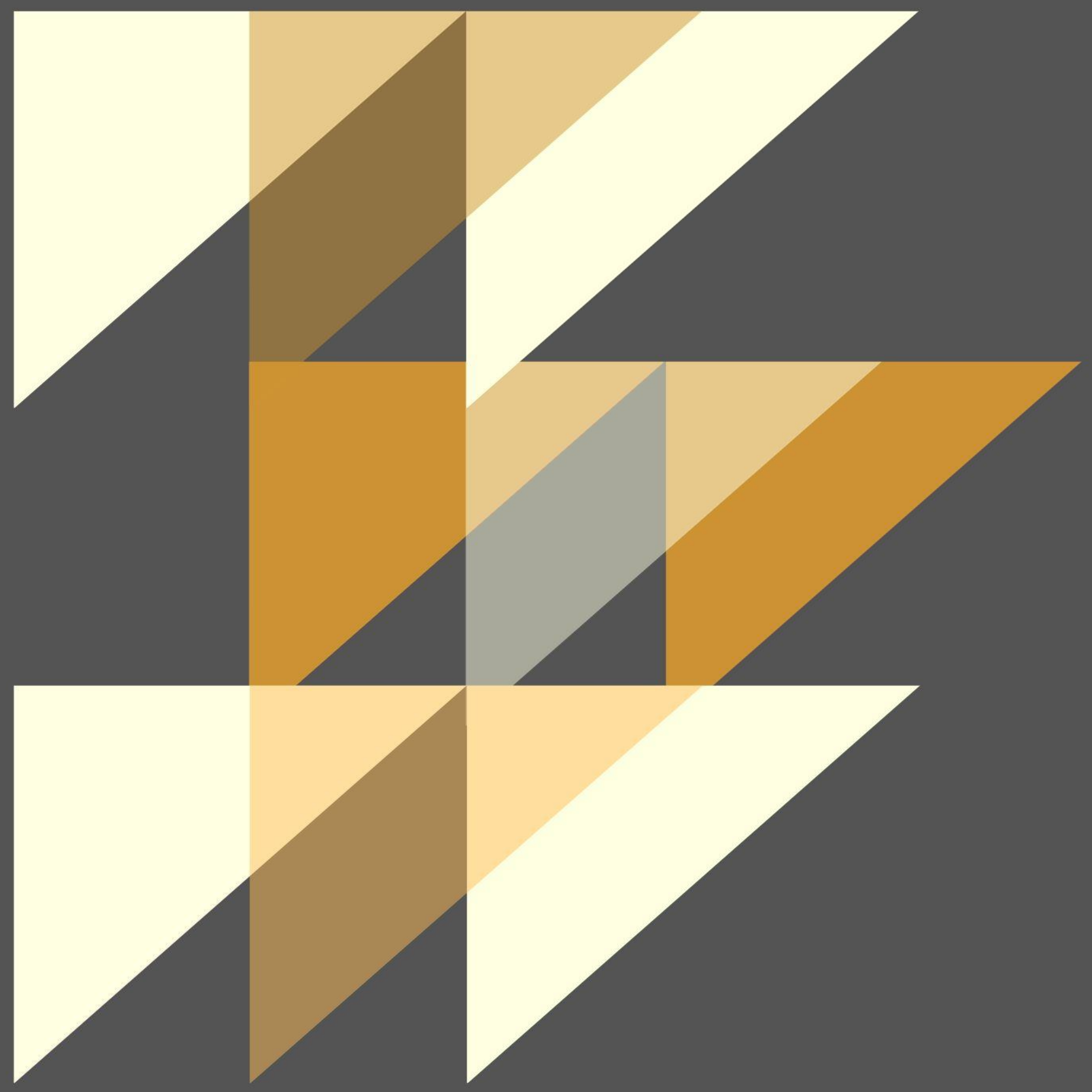

\title{
Tecnofilosofia Líquida:
}

ANDERS, BLUMENBERG E SLOTERDIJK

Orgs.

João Ribeiro Mendes E Bernhard Josef Sylla 



\section{Tecnofilosofia Líquida: ANDERS, BLUMENBERG E SLOTERDIJK}

Orgs.

João Ribeiro Mendes \& Bernhard Josef Sylla 
FICHA TÉCNICA Título: Tecnofilosofia Líquida: Anders, Blumenberg e Sloterdijk Orgs. João Ribeiro Mendes e Bernhard Josef Sylla Editor: Centro de Ética, Política e Sociedade Ano: 2019

ISBN: 978-989-33-0068-8 DOI: $\underline{10.21814 / 1822.61953}$ 


\section{Índice}

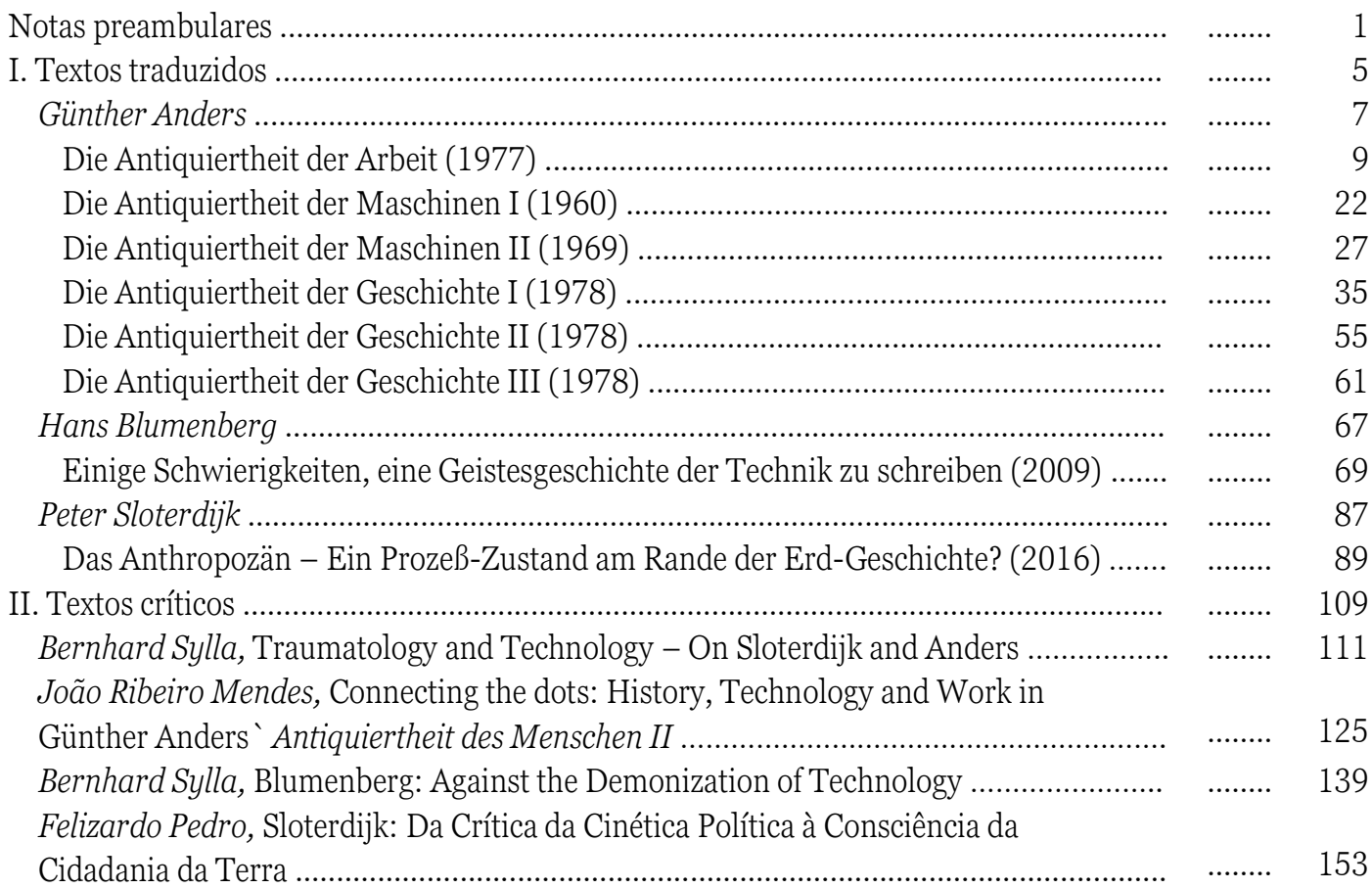





\section{Notas preambulares}

O presente livro que apresentamos ao público de expressão portuguesa resulta do trabalho desenvolvido no âmbito da "Ação integrada Luso-Alemã A46/16", financiada pelo DAAD (Deutscher Akademischer Austauschdienst) e pelo CRUP (Conselho de Reitores das Universidades Portuguesas) e intitulada "Tecnoética líquida de Günther Anders, Hans Blumenberg e Peter Sloterdijk", que decorreu ao longo do biénio de 2016-2017. Colaboraram nesta ação professores e investigadores da universidade alemã Technische Universität Braunschweig (Nicole Karafyllis, Stefan Lobenhofer e Steffen Stolzenberger) e da Universidade do Minho, em Braga, Portugal (João Ribeiro Mendes, Bernhard Sylla, Marco Marian e Felizardo Pedro). Embora a responsabilidade por esta edição seja exclusivamente do grupo de pesquisa da Universidade do Minho, os editores e colaboradores querem exprimir a sua gratidão aos colegas de Braunschweig pelos frutíferos debates e pelas reflexões críticas e estimulantes sem os quais não se teria chegado ao resultado que aqui se apresenta.

Um traço comum de muitas investigações científicas e filosóficas é a experiência de que o tema inicial e com este o objetivo principal da investigação podem sofrer alterações devido ao desenvolvimento da investigação em curso. É esta experiência que também nos ocorreu neste projeto. O enfoque inicialmente colocado no aspeto ético das teorias dos três autores aqui abordados era decerto legítimo, mas revelou-se a posteriori demasiado restrito, tendo em conta a complexidade e abrangência das questões que se levantam quando se confrontam precisamente estes autores. Daí que achemos que o título atual seja mais adequado do que o título originalmente proposto para a Ação. Mantivemos a alusão à noção baumaniana da "liquidez", pois parece-nos que toda a tecnofilosofia, e mais ainda uma tecnofilosofia que se insere nas recentes reflexões em torno do novo conceito de "Antropoceno", ainda esteja em vias de se constituir, facto que implica não só a busca de fundamentos sólidos, mas também a vantagem de todos os recém-nascidos: plasticidade, abertura e atenção aguda aos acontecimentos atuais.

Os três autores traduzidos e comentados neste livro, Günther Anders, Hans Blumenberg e Peter Sloterdijk, são filósofos alemães. Günther Anders (1902-1992) é ainda pouco conhecido em Portugal, e a quase totalidade dos seus textos aguarda ainda tradução para o português. Embora tenha obtido a sua formação filosófica sob orientação e influência dos grandes filósofos dos tempos da República de Weimar, como Husserl - orientador da sua tese de doutoramento em Filosofia - Heidegger e Cassirer, para não falar do seu contato íntimo com Hannah Arendt com quem esteve casado entre 1929 e 1936, Anders desenvolveu a sua atividade filosófica fora do contexto académico. Exilando-se do país natal 
aquando da ascensão da ditadura nacional-socialista, Anders escreveu as suas obras principais em Nova Iorque, como pensador livre. Toda a sua vida foi profundamente marcada pela luta intelectual e militante contra a política do armamento nuclear. Contudo, seria redutor ver nesta luta acérrima o único aspeto interessante da sua obra. Antes pelo contrário, a análise da relação entre o homem e a tecnologia chega a resultados inéditos que permitem encarar o fenómeno da crescente tecnicização do mundo e do seu impacto sobre a condição humana de uma forma nova e deveras pregnante. Consideramos que este enfoque é paradigmaticamente representado pelos textos aqui traduzidos sobre a obsolescência do trabalho, das máquinas e da história, que constam do segundo volume da obra principal de Anders, A Obsolescência do Homem.

Hans Blumenberg (1920-1996) é, tal como Anders, um autor ainda pouco trabalhado em Portugal. Professor de Filosofia nas universidades alemãs de Hamburgo, Gießen, Bochum e Münster, os interesses de Blumenberg concentraram-se, por um lado, em estudos filosófico-históricos, incidindo particularmente na passagem da filosofia medieval e renascentista à filosofia da Modernidade, e por outro lado em estudos metaforológicos que congregam as perspetivas histórica e sistemática. Para além disso, um autor atento de Blumenberg notará também a presença da sua formação filosófica que assentara nos dois pilares da filosofia escolástica e da fenomenologia husserliana. Munido de uma enorme erudição, fruto de uma investigação quase que obcecadamente realizada durante décadas, Blumenberg também legou à posteridade um conjunto de escritos sobre a técnica, editados muito recentemente, em 2015, pela editora alemã Suhrkamp. O texto aqui traduzido de Blumenberg é um bom exemplo da argumentação subtil e densa do autor, que se adequa à complexidade da rede de motivos e motivações teóricas e práticas que, segundo Blumenberg, funcionaram como motores da história do desenvolvimento da "técnica". Se compararmos Anders e Blumenberg, saltará logo à vista a questão fundamental da controvérsia entre tecnófobos e tecnófilos que marcou profundamente o debate sobre a técnica nas primeiras décadas do pós-Segunda Guerra Mundial. Seguindo os moldes deste debate, Anders seria um tecnófobo e Blumenberg um tecnófilo moderado. Pensamos, no entanto, que este enquadramento não é suficiente para captar as ideias estimulantes e inspiradoras dos dois filósofos, porque as suas análises conduzem o leitor às portas de uma reflexão mais profunda sobre a lógica do desenvolvimento tecnológico. Nesta reflexão, os dois autores apresentam resultados deveras diferentes.

O artigo aqui traduzido de Peter Sloterdijk (*1947), na versão alargada e revista de 2016, coloca esta mesma questão do desenvolvimento tecnológico a partir da perspetiva do "Antropoceno", perspetiva essa que começou a constituir-se apenas no século XXI. Sloterdijk, cuja obra se poderia dividir - como acontece com autores como Wittgenstein e Heidegger - em duas fases distintas, tinha defendido, antes de 1999, ano em que despoletou uma intensa polémica com Habermas e outros intelectuais da Alemanha, uma posição marcadamente antiprogressista e, implicitamente, tecnófoba. A partir do novo milénio veio a sustentar, no entanto, uma posição que deposita grande esperança numa "homeotécnica" que se distinguiria essencialmente de uma "alotécnica". Usar a tecnologia inteligente, cooperativa e criativamente, corresponderia a uma viragem paradigmática do nosso pensar e agir, não exequível nos moldes do pensamento atual em torno da ameaça cada vez mais premente do colapso total do planeta Terra. 
Esta brevíssima caraterização das perspetivas que se abrem à investigação quando comparamos e confrontamos estes três autores escolhidos, indica um caminho de pesquisa que se pré-orienta em duas questões: (i) Num primeiro plano, salta à vista a emergência da problemática que se veio a constituir no século XX, a de assumir uma posição fundamentada perante o fenómeno do veloz desenvolvimento tecnológico que começa a ameaçar a sobrevivência da espécie humana e do seu habitat. Esta ameaça evoca quase que naturalmente um compromisso com juízos de valor radicais a favor ou contra a "técnica". Esta reação, todavia, que parece natural no momento histórico quando o feito humano alcança, pela primeira vez, a dimensão de poder extinguir o seu próprio dono e criador, cederá muito rapidamente espaço a uma reflexão mais ponderada. (ii) Desta forma surge, num segundo plano, o desejo de se libertar da vinculação às dicotomias demasiado agrestes, que estruturaram a reflexão pós-guerra sobre a "técnica", e de chegar a um entendimento mais sóbrio e talvez mais equilibrado sobre as causas, os motivos, os mecanismos e a lógica do desenvolvimento tecnológico, e sobre as suas condições sociais, éticas e políticas. As obras dos três autores podem ser lidas a partir de ambos os aspetos. E julgamos que os comentários e artigos reunidos neste livro dão conta disso.

Com base nestes pressupostos, optou-se por prescindir da ideia de limitar o teor dos artigos a comentários estritamente relacionados com os textos traduzidos dos três autores. Embora estes textos sejam importantes e tenham perfil suficiente para servir como porta de entrada para um estudo mais incisivo, não seria adequado caraterizá-los como exemplificadores e paradigmáticos para o respetivo pensamento dos autores. Daí a função dos artigos ser importante por fornecerem reflexões complementares, capazes de conduzir o leitor a outras fontes sem descurar o vínculo com os textos traduzidos.

Os autores e editores querem ainda agradecer ao Deutscher Akademischer Auslandsdienst (DAAD) e ao CRUP (Conselho de Reitores das Universidades Portuguesas) o financiamento da Ação integrada Luso-Alemã que preparou o solo para o projeto da edição deste livro. As traduções dos respetivos textos foram realizadas por João Ribeiro Mendes (Blumenberg e Anders) e Bernhard Sylla (Sloterdijk) e revistas, reciprocamente, pelos mesmos. 

I

Textos traduzidos 

Günther Anders 



\section{A obsolescência do trabalho ${ }^{1}$} 1977

Se demagogos como Hitler ou Goebbels hoje aparecessem prometeriam aos seus povos, a um tempo, racionalização e pleno emprego ou, melhor, promoveriam a racionalização como condição do pleno emprego. Mas porquê colocar esta frase no condicional? Se esses povos fossem tão fáceis de enganar, como o Povo alemão em 1933, dariam gritos de júbilo em face dessa dupla promessa e precipitar-se-iam exultantes no abismo. Mas de novo: porquê colocar esta frase no condicional?

$\S 1$ As privações do trabalhador. "Chaplinite"

Não podemos responder à questão sobre se o trabalhador atual ainda é um proletário ou não determinando o seu nível de vida, mais ou menos elevado - assim visto, centenas de milhões de trabalhadores já não são efetivamente proletários -, mas determinando o seu nível de liberdade. E este último é de facto tão baixo que a resposta à pergunta tem que ser cem por cento afirmativo. Ele não está apenas privado de liberdade porque se encontra excluído da propriedade dos "seus" meios de produção ou dos "seus" produtos, mas também porque não pode abarcar com o seu olhar a totalidade do contexto de produção no qual está integrado; porque tão pouco conhece o produto final e a sua finalidade - que lhe permanecem de certa maneira "transcendentes" -; porque ignora de idêntico modo as qualidades morais ou imorais do "seu" produto; porque não sabe mais quem dele beneficiará, quem o utilizará ou quem será vítima sua. Tudo isso - e, por conseguinte, também o seu próprio trabalho - se passa de certo modo nas suas costas. Foi assim que as coisas se passaram comigo e com o conjunto do pessoal com quem //92 trabalhei, faz mais de trinta e cinco anos, numa fábrica da Califórnia.

A única coisa que tínhamos "diante dos olhos” era um fragmento do produto que não cessava de se aproximar de nós e logo desaparecer e para cujo fabrico ali tínhamos sido colocados - de qualquer modo não desejávamos ver nem saber mais a esse respeito, tinham-nos tirado qualquer espécie de curiosidade, faltava-nos qualquer tipo de interesse pelo que fazíamos. Por que é que deveríamos estar curiosos? Que conseguiríamos com isso? Sobretudo: era preciso que trabalhássemos sem finalidade, sem manifestar interesse pelo que executávamos. Se algum de nós tivesse interrogado o contramestre ou qualquer outro sobre a finalidade daquilo que fazíamos, na melhor das hipóteses ter-nos-iam respondido com um extravagante - "That's none of your damned business" - e alguns anos mais tarde,

1 Traduzido a partir de: Anders, G. (1992). Die Antiquiertheit des Menschen. Bd. 2: Über die Zerstörung des Lebens im Zeitalter der dritten industriellen Revolution (pp. 91-109). 4. Aufl. München: Beck.

Optou-se pela colocação do diacrítico "//“ seguido de um numeral para assinalar a mudança de página na edição que serviu de base à tradução. As notas do autor a este capítulo, colocadas aqui em rodapé, encontram-se reunidas na edição usada entre as páginas 438-439 [nota dos editores]. 
durante o período McCarthy, teria sido considerado "security risk". De facto, seria conceder honra demasiada ao que fazíamos na época qualificando-o de "trabalho", para além de que seria também um erro. Como permanecíamos cegos à finalidade daquilo que ocorria, tratava-se bem mais de uma espécie de ginástica que éramos obrigados a fazer oito horas por dia, consistente em exercícios livres ou, melhor, "não-livres" sempre iguais, pois que havia ainda de "livre" nesses movimentos ditados pela cadeia de montagem? Décadas antes Chaplin já tinha representado esses "exercícios não-livres" no seu filme Tempos Modernos, mostrando um homem que, ao entardecer, regressando do seu trabalho na linha de montagem, não é livre o suficiente para se livrar daqueles tais movimentos não-livres e observa desconcertado o bailado das suas mãos, semelhantes a estranhos animais: "Chaplinite". Na verdade, pode ter-se medo e inquietação quando se percebe que, também agora, neste momento, centenas de milhões de trabalhadores estão ocupados com tal ginástica; que esses centenas de milhões podem até dar graças porque, ao contrário dos milhões menos agraciados, os desempregados, a eles ainda lhes é concedido essa ginástica; e proclamando obstinadamente o direito a esta ginástica como um direito político fundamental: de facto, têm que proclamá-lo, porque sem semelhante ginástica inútil ficariam sem nada, ou ficariam sentados diante do ecrã de televisão - se bem que este "fazer" seja apenas um forma dissimulada de não fazer nada e porque estariam condenados a ir engolindo diariamente massa do tempo, que se acumula sem parar diante deles. //93 É ainda mais preocupante se se pensa que essa ginástica não pode ser interrompida ou corrigida por qualquer tipo de revolução; que a nossa descrição se aplica tanto ao trabalho nos países socialistas como ao trabalho nos países capitalistas; ou seja, que as consequências da técnica não se transformaram nem com a transformação das relações de propriedade; que o discurso da "humanização do trabalho" e "superação da alienação" é e será definitivamente mera conversa fiada enquanto vivamos em um mundo tecnificado, que cada vez o está mais.

E com isso chego à afirmação ligeira, hoje tão frequentemente repetida sem pensar, que já não há proletários. Na verdade, existem hoje mais do que nunca, pois se aqueles que passam a maior parte de sua vida vígil com "exercícios não-livres" - e esses são quase todos os assalariados - e ao terminar o dia só têm força ${ }^{2}$ para produtos de diversão ministrados em casa; ou se aqueles que são excluídos até mesmo dessa possibilidade de trabalhar nãolivremente, ou seja, os desempregados - e todos aqueles não são proletários, então já não sei o que pode significar essa palavra.

A isso deve acrescentar-se que não é tão certo que o trabalho na cadeia de montagem seja, na verdade, "trabalho" no sentido clássico, porque o que "fazemos" na cadeia de montagem não é uma entidade gestual, uma ação rotunda em si mesma, na qual possamos envolver-nos como o carpinteiro na fabricação de uma mesa ou do violinista na melodia ou mesmo o lenhador no seu corte. A nossa prestação consiste, ao invés, apenas em fragmentos de uma atividade com os quais nunca podemos identificar-nos, mas que temos de repetir mil vezes sem nos identificarmos com eles. Uma vez que não nos proporciona nem a alegria do produto, que vai sendo feito, nem o produto acabado, o trabalho na cadeia de montagem é

2 Durante o tempo em que trabalhei na fábrica não representei uma exceção. Não havia então televisão, mas apenas a rádio. Porém, também vivi na altura na companhia desta. 
pior, para não dizer, muito mais maldito que qualquer trabalho anterior. Esse tipo de trabalho é o que nos converte em proletários. //94

$\S 2$

Automatização. O segundo desemprego

Mas isso não é tudo: embora o trabalho alienado seja já realmente inumano; embora seja impossível renunciar a ele; embora nenhum sistema político possa ter interesse em renunciar a ele; e embora nenhuma revolução política estivesse em condições de renunciar a ele, não é o pior dos trabalhos. Com isso, certamente, não me refiro a que existam trabalhos física e espiritualmente mais pesados que o descrito. Pelo contrário: o que quero dizer é que, visto superficialmente, é um trabalho muito leve; tão leve que, de facto, uma vez que já não somos pastores, o que entendemos por "trabalho" ainda se parece menos ao que o trabalho taylorista faz. É o pior porque nos retira completamente a liberdade. Na verdade, a sua introdução é de per si uma revolução que com muito pouca assincronia se dá ao mesmo tempo no Este e no Ocidente. Refiro-me à automatização.

No entanto, a maioria dos trabalhadores atuais ainda não pertence à categoria de servidores da automatização. Mas a tendência é imparável: em 2000 prevê-se que a maioria dos trabalhadores serão trabalhadores da automatização. Naturalmente, isso não quer dizer então que todos os que "estão dispostos a trabalhar" trabalharão para e na automatização, pois há uma lei de ferro da inversão das proporções, que diz que, com o número crescente de automatizações diminuirá o número dos trabalhadores necessários. Dito de outra maneira: é inevitável que, de certo modo como "segundo produto", a partir das automatizações se produzam milhões de desempregados e, portanto, de proletários ${ }^{3}$.

No entanto, se abdicarmos dessa ominosa probabilidade e nos limitarmos a esses poucos afortunados que não se afogarão na sopa do seu indesejado tempo livre, mas que ocuparão efetivamente um posto de automatização, caberia pensar que pelo menos esses terão uma probabilidade - por mais mesquinha que seja - para continuar a fazer cegamente "exercícios livres". Não, também essa suposição é demasiado otimista. Ainda assim esses "afortunados" estarão condenados ao desemprego ou, respetivamente, já estão desempregados. //95 Isso parece absurdo, mas não é, porque o desemprego de que aqui estamos a falar é de um tipo totalmente novo, a saber, um desemprego cuja duração será idêntica à do trabalho. Com isto quero dizer que para os ocupados em empresas automatizadas - é indiferente que se chamem "trabalhadores" ou "empregados": pois aqui não é mais válida a distinção - durante o seu trabalho nem sequer estarão obrigados a realizar aquela "ginástica", que antes identificámos como síntese da inumanidade atual; não, nem sequer terão liberdade para isso. Gentilmente banhados por uma música de rádio, o seu dever consistirá, de certa forma, em não fazer nada; supostamente, apenas de determinada forma, pois estarão ocupados a aguardar se por acaso (isto é apenas um exemplo) uma luz normalmente verde fica vermelha (coisa que propriamente nunca deveria acontecer e, de fato, acontece apenas raramente) e indica uma avaria. Claro, eles têm que realizar este

${ }^{3}$ A frase de Marx "A redução da jornada laboral é a condição básica" (do "florescimento" do "verdadeiro reino da liberdade”) (O capital, III, Berlim, 1953, pág. 873) soa como se fosse de outra época. 
"aguardar" da maneira mais concentrada (e isso, psicologicamente, é um caso único) são os "Linceus" da era industrial. A expressão "aguardar" é usada de bom grado porque tem um duplo significado: não apenas "aguardar que" ou "aguardar se", mas na sua forma transitiva guardar algo, que supostamente indica a custódia ativa de alguma coisa. Este segundo sentido interpela de facto quem aguarda. Aquele que aguarda tem de sentir-se como um guardião. Ora, "guardião" apenas o é numa pequena percentagem dos casos. "Pastor do objeto" seria a descrição mais precisa do trabalhador da automatização. Esse é o bucolismo atual. Na verdade, na história das atividades humanas desde o antiquíssimo ofício do pastoreio que não tem havido nenhuma que, embora sendo na verdade uma maldição, se tenha diferenciado tão fundamentalmente do "trabalho maldito" (I Moisés 4 [Génesis 3, 19]) como a situação dos trabalhadores de automatização. Mesmo o suor lhe é negado. Não estou inteiramente certo que se tenha direito a subsumir o seu não fazer nada e o esgotar-se do lavrador sob o conceito geral "trabalhar". Na verdade, em comparação com a frustração de quem atua na automatização, o trabalho na linha de montagem, descrito anteriormente e ainda hoje preponderante, é uma ocupação divertida - quase estamos tentados a dizer: digna do homem - apesar da cegueira a respeito da sua explicação, pois em todo o caso continua a manter os trabalhadores //96 em movimento. Pelo menos, esse trabalho parece um fazer.

A isso se acrescenta, como um segundo negativum, que o "guardião" aguarda que nada aconteça. Duvido que o homem seja capaz de aguentar essa segunda negatividade. Provavelmente, aquele que aguarda anseia por que se acenda a ominosa luz vermelha com tanta impaciência como o polícia, que anda de um lado para o outro, frustrado durante horas, aguardando o aparecimento de um delinquente, pois isso demonstra-lhe que a sua ocupação não é totalmente inútil e sem objeto.

Finalmente, o terceiro negativum - e neste ponto nunca se fará suficiente finca-pé consiste na forçada insociabilidade do "aguardar". Enquanto os trabalhadores da cadeia de montagem ainda se sentem de alguma forma uns junto aos outros, permanecem em contato (ainda que seja apenas um contato como o dos prisioneiros das galés), os trabalhadores da automatização têm que fazer a guarda como solistas e, para além disso, não se movendo, pois hão de cumprir o seu dever sentados. Ao caráter eremítico dos consumidores atuais (por exemplo, da televisão), que descrevi no primeiro volume ${ }^{4}$, corresponde o caráter eremítico dos atuais trabalhadores (da automatização). Na verdade, estes já não encontram a seu lado qualquer camarada: se têm sede de sociabilidade, em vez de dirigir-se ao vizinho, no máximo podem dirigir-se à própria empresa, ou seja, a uma coisa. Quem sabe se a ideia com a qual ainda crescemos nós que hoje temos setenta ou oitenta anos e que durante mais de cem anos conferiu a sua força de choque aos movimentos socialistas, a saber, que os trabalhadores tinham que sentir-se "massas de trabalhadores" e que, somente se assim o fizessem, isto é, se se sentiam e atuavam de maneira solidária, poderiam ganhar peso político e liberdade; quem sabe se esta ideia não será incompreensível para as próximas gerações, porque a situação laboral não envolverá qualquer referência a um team, para não falar de massa ou classe. Certamente não é uma mera coincidência que as litografias de Käthe Kollwitz, no passado famosas, que representavam as massas da revolução, não tenham voltado a ser penduradas depois de 1945, e em 1933 tenham sido à pressa tiradas das

${ }^{4}$ A obsolescência do homem, Segunda parte I, 9. 
paredes. O futuro representado nessas imagens tornou-se passado antes de ter podido chegar a ser presente. Estas imagens perderam a sua "verdade"; e //97 ninguém se reconhece já nelas. E quem sabe se amanhã muitos trabalhadores trabalharão eremiticamente unidos ao seu mundo circundante como os atuais astronautas nos seus foguetões. E se depois de amanhã as palauras "consciência de classe" e "parceiro" e até mesmo o termo "trabalho" não estarão igualmente caducos, como já hoje o está o termo "trabalhador" (substituído pelo termo enganoso "empregado").

E, no entanto, aqueles que guardam, i.e. os vigilantes que "não fazem nada", erão amanhã os favorecidos, porque não há dúvida que as empresas automatizadas se tornarão quase autónomas, isto é, renunciarão o mais possível aos trabalhadores. No Japão já existem "unmanned factories". Logo haverá também noutros lugares "unmanned offices", porque hoje os computadores calculam quase 1.000 .000 vezes mais rápido que os seus criadores 5 , se se lhes exigir as mesmas tarefas, que já estão imensamente atrás no que diz respeito às suas criações ${ }^{6}$. Inumeráveis serviços especializados, que há vinte e cinco anos quando trabalhava no primeiro volume desta obra tinham que ser realizados por pessoas, podem agora ser executados automaticamente e, para além disso, com muita maior precisão e a um ritmo de trabalho mil vezes maior. O trabalhador já não experimentará a "vergonha prometeica" ali descrita, a vergonha ante o aparelho (que ele serve) de ser menos perfeito que ele. Na verdade, o Linceu de amanhã, sentado na cabina do seu cosmos de aparelhos, não encontrará a oportunidade nem se verá levado a comparar a sua "própria prestação" com a máquina. Esta não trabalha na sua vez, do indivíduo, mas por todo o turno; e isso significa: a diferença de desempenho tornou-se demasiado grande - alguns complexos de máquinas substituem já 50.000 trabalhadores - para que se possa ter uma comparação. E, no entanto, apesar da situação degradante em que se encontram estes condenados a "aguardar", formarão a elite dos trabalhadores e dos empregados, pois - não para forjar ilusões - a maioria dos proletários, por mais que queira trabalhar, aguardará em vão para ser empregue como "aguardador".

Não se transformará a humanidade num único colossal e global proletariado lumpen? //98 E mesmo que se conseguisse - algo bastante improvável - manter a atual sociedade de bem-estar mediante uma reestruturação completa do sistema social, em que vão ocupar-se milhões de pessoas de manhã à noite? É ridículo acreditar que se pode responder a esta pergunta com propostas de educação popular. Não estarão, desamparados, expostos ao oceano do tempo livre? A pergunta: "O que devemos fazer?", que os melhores homens do século passado e de inícios do XX tentaram responder, será substituída por esta: "Em que vamos ocupar-nos nós e os nossos semelhantes?". Duvido e enjeito que milhões de pessoas possam encher o oceânico tempo vazio com divertimento, "formação", desporto ou sexo. E não porque eu sou um fanático, intransigente e invejoso, da ética do trabalho, nada mais longe de mim que pregar, levantando o indicador, que só merecem viver aqueles que ganham a vida com o seu trabalho. O que creio é que o homem não pode viver sem trabalho, ao qual foi condenado; que é incapaz de se divertir around the clock. Os conselhos daqueles que já não podiam suportar as misérias da humanidade, chamem-se Tolstoi ou Lenine, estão obsoletos face à situação completamente nova da humanidade: também eles estão obsoletos.

${ }^{5}$ Das Argument, número especial 19, pág. 92.

$6 \mathrm{O}$ theologumenon molússico, segundo o qual o mundo criado por Deus é superior às suas forças, procede presumivelmente de experiências semelhantes. 
A questão já não é como se repartem justamente os frutos do trabalho, mas como tornar suportáveis as consequências do não trabalho. Por repugnante que pareça a expressão "design do tempo livre"7 - desconfio da palavra "design"; forma parte da lista negra de palavras proscritas -, pelo menos, o termo "tempo livre" mostra aquilo de que hoje se trata. Naturalmente, não tenho uma resposta.

Bons tempos aqueles em que os "empregados" 8 chamados trabalhadores (que todavia nunca tinham a liberdade de tomar o seu trabalho) eram tidos e considerados como tais, uma vez que o desemprego que agora se anuncia fará com que pareça inócuo o de há cinquenta anos. Se se tem em consideração que já aquele desemprego foi uma das principais causas do nacional-socialismo, não se terá a coragem de imaginar o que produzirá este desemprego que já nos ameaça. Não é de todo impossível que os fornos de gás de Auschwitz //99 (economicamente absurdos na altura) sejam os modelos para a "superação" do facto de que, em comparação com as condições de trabalho, "existam demasiados homens".

Mas o transtorno que hoje sofre o trabalho não se descreve exaustivamente pela referência à racionalização. Pelo menos tão fundamental como a revolução causada pela automatização é a que consiste em que atualmente se têm intercambiado o meio e o fim. Imediatamente se verá que ambos são só fatores de um único transtorno. Na verdade, é hoje certo que cada indivíduo considera o seu trabalho como meio (para a compra de meios de subsistência, em sentido amplo). Mas enquanto antes a finalidade do trabalho consistia em satisfazer necessidades criando produtos, hoje a necessidade tem como meta os postos de trabalho; a criação de trabalho converte-se numa tarefa: o trabalho em si torna-se o produto a ser criado; uma meta que só se pode alcançar criando produtos intermédios. Estes novos produtos chamam-se "novas necessidades": que se criam mediante um trabalho denominado "publicidade": uma vez criadas estas necessidades, exige-se e possibilita-se também um novo trabalho como produto final.

Naturalmente, não ad libitum. Não só porque o nosso "poder ter necessidade" não é ilimitado (o que se poderia continuar a desejar depois de comprar uma "máquina de escrever que pode funcionar debaixo de água”?), mas sobretudo porque com o aumento imparável da técnica, com o aperfeiçoamento imparável da racionalização e da automatização diminui constantemente o número dos trabalhadores necessários para uma determinada prestação. o postulado do pleno emprego é, portanto, tanto menos realizável quanto maior o status tecnológico de uma sociedade. Quando alguns políticos da Europa Central alegam que é preciso elevar o nível tecnológico dos seus países, porque só assim poderão garantir o pleno emprego, ou são incapazes de pensar ou são demagogos. Não se pode inserir ao mesmo tempo no programa a máxima racionalização que diminui o número de trabalhadores necessários, e o pleno emprego. Esse tipo de erro lógico não seria admissível fora da política. A dialética atual //100 consiste nessa contradição entre racionalização e pleno emprego. Nenhum político se atreve a admiti-lo abertamente.

\footnotetext{
${ }^{7}$ Em alemão "Freizeitgestaltung" [nota dos editores].

8 Em alemão "Arbeitnehmer" que significa, à letra, "tomador do trabalho" [nota dos editores].
} 
Do mesmo modo que existe um $\mathrm{IQ}^{9}$ ter-se-ia de introduzir um WQ (workers quotient): a sua medida descreveria a percentagem daqueles cujo trabalho é indispensável para manter a vida de cem pessoas. Assim, WQ 100 significaria que são necessárias cem pessoas para manter cem, coisa que parece ideal, pois cada qual deveria ter - isto é, teria um posto de trabalho. No entanto, no sistema capitalista não se pode dizer que essa "cobertura" seja ideal; por três razões.

Primeira, porque mantendo a produção de um determinado número de desempregados, cada posto de trabalho converte-se num desideratum e, desse modo, enfraquece a classe trabalhadora.

Segunda, porque o aumento do lucro requer a racionalização e, portanto, a diminuição dos postos de trabalho.

Terceira, porque é preferível que bastem 10 por cento para manter "100 por cento", ou seja, porque cada empresa trabalha com o propósito de que o crédito que tem exceda o débito.

Ao mesmo tempo, no entanto, aspira-se à utopia do país de Jauja WQ = Zero; ou seja, à situação em que ninguém precise de trabalhar, porque todo o trabalho é confiado aos aparelhos. Assim, WQ 4 significa: são necessárias quatro pessoas para assegurar as vidas de uma centena. Quanto maior é o status tecnológico de um país, menor é o seu WQ. Ora, como a quantidade do que é indispensável é relativa - o que é indispensável em Los Angeles não o é em Calcutá - e depende do status tecnológico alcançado, sempre será preciso utilizar com reservas o dado do WQ. Na sociedade capitalista altamente industrializada aplica-se a regra: nunca são necessários $n$ homens para manter $n$ homens. Sempre se necessitam $n$ menos $x$ homens para manter $n$ homens. Quem quiser combater o desemprego reeducando os "libertos" (como hoje se diz tão elegantemente; //101 embora assim já não saiba o que significa liberdade) de um trabalho (por exemplo, o dos tipógrafos) para outro ofício é um reformador minimalista pois não pensa no facto de que com a racionalização não desce só o WQ num setor, mas em toda a indústria; ou seja, que a racionalização diminui absolutamente o número de postos de trabalho. Se esta regra não é válida nos estados socialistas e eles se vangloriam da inexistência de desemprego, de modo indireto vangloriam-se de que a regra ainda não é válida, ou seja, de um sinal de seu atraso tecnológico.

Ao WQ corresponde o HQ ( $\mathrm{H}$ = hour), que indica quantas horas alguém tem que trabalhar para poder viver. HQ 24 significaria: para poder viver há que trabalhar vinte e quatro horas sem descanso; HQ 4: há que dedicar quatro horas a trabalhar. WQ e HQ diminuem simultaneamente. E isto é verdade não só na indústria (em sentido estrito), mas absolutamente, por exemplo, para o proprietário de uma empresa, cujo tempo de trabalho (através de aparelhos eletrónicos) foi cortado a ponto de se poder transformar num trabalhador a tempo parcial, ou mesmo tão mínimo que é quase um “desempregado" (HQ =

${ }^{9}$ Abreviatura de "intelligence quotient", quociente de inteligência em inglês [nota dos editores]. 
0). Este é um desemprego totalmente novo, ou seja, um desemprego que se pode dar ao luxo de o ter. Neste caso, o desemprego é, pois, um estádio de ascensão social10.

O “labor", que durante milénios e também na minha juventude foi reconhecido como virtude - no boletim de notas escolares inclusive mencionava-se como um mérito particular - está agora obsoleto. Só vale propriamente como indício de um trabalho não racional e como meio de perder tempo. Quem precisa de duas horas para um serviço que poderia resolver numa hora, torna-se ridículo como um tolo.

\section{$\S 4$}

A transferência da voluptas laborandi, da voluptas concurrendi e da voluptas solidaritatis para o ócio: o desporto, nova divisão do trabalho

Que saída temos hoje ante esta situação de trabalhar e não trabalhar? Pois hoje, ainda que a automatização //102 não tenha triunfado em toda a linha, o trabalhar também ficou defraudado em relação ao esforço do trabalhar; e não apenas em relação ao esforço, mas ao gosto pelo esforço, à irrenunciável voluptas laborandi. Temos sido desapossados da prova de existir que antes o trabalhar tinha proporcionado: "Suo, logo sou". Certamente, seria um atrevimento afirmar que os trabalhadores e empregados atuais tenham saudades do trabalho mais fatigante dos tempos passados ou mesmo que um dos motivos do radicalismo ludita do século XIX foi a relativa (sublinho: relativa) leveza do trabalho com máquinas. Amanhã, no entanto, a ânsia de esforço ou, pelo menos, de fazer será esmagadora. Já hoje eu vejo diante de mim os nossos bisnetos: pastores da automatização e desempregados, que terão saudades do antigo trabalho na linha de montagem, apesar deste consistir exclusivamente em movimentos desumanizadores e chaplinescos, porque ainda conservava um mínimo fazer, portanto algo comparativamente humano, e os eximia do esforço de terem que matar o tempo eles mesmos: radicais luditas que, no entanto, terão tão pouco sucesso como os seus antepassados, os radicais luditas do século XIX. As metas dos terroristas de amanhã (tal como as metas oficiais dos Estados em guerra) serão os grandes estabelecimentos industriais, uma vez que os atos de violência que hoje levam a cabo grupos conspiradores por desespero ante a "falta de sentido" da sua vida ou com a esperança de uma prova de existência - um ergo sumus -, tais atos de terror passarão, temo, para as mãos das massas tanto mais rapidamente quanto mais incontestável for o triunfo das automatizações.

Entretanto, os trabalhadores e os desempregados têm de se contentar com outros métodos para recuperar esforços invejados. Na verdade, existe um método, apenas um, que se tem revelado extraordinariamente bem-sucedido: o desporto.

O seu papel seria incompreensível sem uma análise do trabalho atual. "A que é que se dedica habitualmente pela tarde, depois do trabalho?”, perguntei (há já vinte anos) a um

\footnotetext{
10 "Só meia hora por dia", lê-se no Der Spiegel (21.11.1977), dedica o agricultor Groth, que alimenta anualmente dois mil porcos para o matadouro (montante: 700.000 marcos) numa quinta que vale 280.000 marcos. Abrir e fechar as torneiras de trabalho. Tudo o resto funciona sozinho (...) Assim, numa hora podem estar ordenhadas oitenta vacas em dez estábulos, comodamente e sem esforço (...) Cedo, Groth vai caçar.” De passagem, é notório que o tempo de que o senhor Groth já não necessita para preparar os seus bovinos para abate, dedica-o a matar outros animais.
} 
trabalhador automatizado em Marl, que tinha o seu olhar fixado numa luz verde. A sua resposta (sem interromper a sua fixação): "Naturalmente, futebol. E, claro, duas vezes //103 por semana, levantamento de pesos" ilustra a minha observação anterior de que os trabalhadores atuais têm saudades dos esforços dos seus antepassados. O duplo "naturalmente" na sua resposta era de facto muito natural, pois essas duas ocupações desportivas no seu tempo de lazer representavam para ele a natural compensação da sua não natural, ou seja, demasiado ligeira atividade, que "preenchia" o seu "tempo laboral" - não é possível deixar de colocar aspas. Na verdade, a raiz do desporto atual é o atual trabalho demasiado ligeiro. A existência e o desenvolvimento do desporto só podem ser entendidos como existência e desenvolvimento complementares. Isto é: quanto menos fatigante é o trabalho - e o desenvolvimento nesta direção implantou-se no início do século XX para culminar no trabalho automatizado - mais tem de recuperar o homem, construído para trabalhar "de acordo com sua essência"11, o seu esforço absolutamente irrenunciável e a correspondente "voluptas laborandi", de igual modo irrenunciável; por isso, deve transferila para o seu tempo livre. Ora, isto significa que se desenvolve um novo modo de divisão do trabalho. Porquanto esta expressão tem indicado até hoje que a execução de trabalho necessário para a fabricação de um produto tinha de ser repartida por diversas intervenções (naturalmente, mais ou menos fatigantes) de vários homens, aqui o termo indica que a parte "esforço" é separada das demais execuções do trabalho. Este procedimento é extremamente estranho, porque envolve uma dupla liberdade ou, mais precisamente, a aparência de uma dupla liberdade: livre parece (1) a mesma execução do trabalho, enquanto livre de esforço; mas livre parece igualmente (2) esse esforço separado, porque tem lugar como um jogo e diversão e absolutamente voluntário.

Ora, este é obviamente um disparate. Como mostra a dupla utilização do termo "parece" estamos diante de um duplo equívoco, porque (1) "livre esforço" não significa eo ipso "liberdade"; um trabalho sem esforço (como colar sacos ou, precisamente, um trabalho automatizado) é tudo menos livre. E (2) o ócio não é eo ipso uma situação de liberdade; o tipo de ócio está antes determinado pelo tipo de trabalho que nos é imposto e é, portanto, igualmente imposto. Os hobbies, que fingem ocupações de ócio eleitas com liberdade, estão determinados pelos objetos do hobby, que são oferecidos //104 como mercadorias e estas, por seu turno, são determinadas pelo tipo de trabalho atual, como contratipos. Não se entende por que é que construir um minigolfe (naturalmente, com componentes préfabricados) tem de ser uma "ocupação livre". Quando passamos as nossas férias "fish spearing" ou fazendo surf, fazemo-lo porque nos encontramos sob a pressão dos objetos colocados no mercado, ou seja, pelos produtores. Enquanto clientes de férias do "fish spearing" ou do windsurf somos empregados dos fabricantes, que sedutoramente nos induzem a uma atividade, que nunca temos como trabalhadores: por exemplo, a de matar ou a de correr um "grande risco". A isso se acrescenta que, habituados ao "afável terror" (como lhe chamei há vinte anos) das mercadorias, já não somos capazes nos ocuparmos de nós próprios e por nós mesmos. (Não tenho, porém, a certeza de que os nossos antepassados pudessem ter feito melhor que nós. Provavelmente, especialmente durante o inverno, vegetaram e dormiram com mais facilidade que nós, repletos como estamos de impressões.)

${ }^{11}$ Utilizo com relutância essa expressão de Husserl, pois normalmente (já Scheler) abusou dela com uma finalidade conservadora. No entanto, no presente contexto é inevitável. 
Em todo caso, hoje o ecrã de televisão é cadeia de montagem do ócio. Temos que ir consumindo ao seu ritmo. Em suma: ócio, consumo e desporto são-nos impostos tanto quanto o trabalho. O que experimentamos no trabalho e no ócio não é, pois, como parece à primeira vista, uma dupla liberdade; em vez disso, uma dupla não-liberdade, que é a mentira existencial da época, já que se apresenta revestida de uma dupla liberdade.

\section{$\S 5$ \\ A reparação através do desporto}

Mas com isso não se esgotou a função compensatória do desporto. Existem além disso outros defeitos do trabalho atual que são reparados através do desporto.

Ao passo que enquanto trabalhadores da cadeia de montagem somos enganados sobre a possibilidade de nos identificarmos com a nossa atividade e de ver diante de nós os resultados do próprio trabalho, enquanto desportistas (corredores, nadadores, esquiadores) não só somos capazes de ser unos com a nossa ação (e de maneira mais feliz), mas também incapazes de não o ser. E mesmo com isto não fica ainda dito tudo. O que falta ao trabalhador atual - um defeito que se tentou reparar uma e outra vez, aqui através do trabalho //105 à tarefa, lá através da "competição socialista" ("Stakhanovismo") - é o "momento agónico", ou seja, a possibilidade de competir, o gosto pela competição e o desejo de vencer competindo. O que os filósofos triviais do capitalismo, em especial nos seus apelos aos jovens empresários, censuram nos socialistas ${ }^{12}$, que querem eliminar a possibilidade da livre concorrência, é justamente isso que a industrialização faz tempo tem levado a cabo mediante a introdução de técnicas de trabalho desumanizadoras (que foram adotadas sem qualquer variação pelos estados socialistas). Em fábricas, eliminou-se quase por completo a possibilidade do "agon" (para não mencionar o prazer do "agon”). O papel do trabalho à tarefa é irrelevante. Mais uma vez vale o que acabámos de dizer sobre o esforço: que se dá uma deslocação, porque na medida em que faltam as possibilidades de competição no decorrer do trabalho e porque o desejo de competição e a "voluptas concurrendi" são irrenunciáveis, esta transfere-se para o tempo do ócio, i.e., de novo para o desporto, que representa a competição dos excluídos da competição real. No desporto ainda se pode, inclusive se deve vencer tanto individual como coletivamente. O desporto é a válvula de escape da ânsia competitiva, é "a competição para o povo"13.

Mas mesmo com isto não fica ainda representada exaustivamente a função vicariante do desporto, pois há que acrescentar - esta é a terceira função - que concede (ou condena) (a)os trabalhadores a/à possibilidade de experimentar aquele sentimento (em absoluto não desejado pela classe dominante) de unidade e de solidariedade, noutro âmbito, uma vez por

\footnotetext{
12 Os ideólogos triviais (como por exemplo Taus, na Áustria), no seu medo de que a época da economia da livre concorrência possa chegar ao fim, voltam a recorrer às fórmulas filosóficas mais ingénuas do adorno e do jornalismo de princípios dos anos vinte, por exemplo: "criatividade", "autodesenvolvimento e autorrealização da personalidade"; que eles supostamente garantem e em contrapartida os socialistas frustram. Nada mais desleal que a suposição de que alguma vez se tenha concedido a um dependente - por exemplo a um campesino ou a um empregado da banca ou a um soldador - a possibilidade de converter-se em uma "personalidade" ou de "desenvolvêla”. Tais vocábulos festivos não provocam nunca sequer risos zombeteiros, apenas justamente uma teimosa incompreensão. Aqueles que falam de "autodesenvolvimento" referem-se diretamente à conservação do "autodesenvolvimento" do capital.

${ }^{13} \mathrm{Na}$ União Soviética, a concorrência foi introduzida de forma artificial de novo: turnos de operários, que produzem um determinado output em menos tempo que outros, são honrados como "heróis do trabalho". Ora, esta concorrência já não é verdadeira. O que aqui ocorre na realidade é que o turno de trabalho consegue com a língua de fora manter o ritmo de uma máquina que funciona mais rapidamente que noutras partes: compete, pois, com esta máquina, não com outros turnos.
} 
semana, até à exaustão e de forma completamente inofensiva (por vezes mesmo num campo desportivo colocado à disposição pelo empresário). O desporto é um apaziguamento substitutivo - bem visto, quando não fomentado - da sede da solidariedade. Agora, os jogadores são solidários com o seu clube de futebol ou como ciclistas, com a sua equipa de ciclismo. E também o são quando não são eles próprios que jogam ou correm, mas na qualidade de membros da família ou amigos olham boquiabertos ou animam com gritos ou só participam sentados diante do televisor: então são solidários como sócios ou simpatizantes dos "Brooklyn Eagles" ou do parisiense "Vélos de Rougemont". E isso significa: não como proletários. A instituição do falso "como" pertence às //106 manipulações ideológicas mais eficazes no Este e no Ocidente. O dictum molússico "O desporto é contrarrevolucionário" não é tão injustificado.

A isto se soma (mas, provavelmente, isso leva à mesma coisa) que o desporto permite aos atletas experimentar a sensação de antagonismo, que normalmente lhes é negada; mais precisamente, condena-os a livrarem-se das energias reprimidas do ódio político transferindo-as para um falso objeto. E não apenas se substitui o objeto da inimizade, mas ainda mais, esse sentimento no menos grave de todos: o da mera rivalidade. É um mau sinal que isto também seja válido no Este, onde se supõe que já não há classes e, portanto, que também não deveria ser mais necessário um sucedâneo do ódio de classe e que também ali se fomente oficialmente o entusiasmo e o ódio de massas na arena desportiva, inclusive se cultive a indústria da competição.

Uma vez produzidos estes pseudoafetos, podem voltar a transformar-se retroativamente em pseudoafetos políticos. Recentemente, na América Central um incidente desportivo degenerou numa autêntica guerra. Os rugidos, que interrompiam e concluíam os discursos de Goebbels (tanto os rugidos de ódio contra o "bolchevismo e judaísmo mundial" como os rugidos de solidariedade em prol da guerra total) tinham sido testados antes nos campos de futebol. Na verdade, também o rugido desportivo soa "assassino". Que as concentrações de massas mais famosas do nacional-socialismo tiveram lugar no berlinês Sportpalast ${ }^{14}$ tem um significado insuperavelmente simbólico: nenhum romancista teria sido capaz de inventar melhor. Claro que tudo isso também vale para o rugido nas festividades do $1^{\circ}$ de Maio no Leste e nas Party Conventions americanas.

Recapitulemos o que se passa aqui. O processo tem três fases:

1. Supõe-se que existem afetos políticos genuínos de solidariedade e de antagonismo.

2. Imputa-se a estes sentimentos novos objetos, transformam-se em (inautênticos) afetos desportivos. Enquanto tais, são incomparavelmente mais intensos do que todos os afetos ou emoções "naturais"; nenhuma pessoa se enfurece com uma raiva natural, seja de que tipo for, tão inumana como o faz num jogo de futebol. //107

3. A estes afetos inautênticos aumentados são atribuídos novos (pseudo) objetos políticos: o fã de futebol grita não pela sua equipa, mas pelo seu Reich e pela guerra total; não contra a equipa adversária, mas contra o bolchevismo e contra o judaísmo mundial.

${ }^{14}$ Palácio de Desporto [nota dos editores]. 
A revolução técnica, única revolução autêntica da nossa época. Economia planificada: o sistema feito à medida da técnica.

Voltemos à nossa pergunta inicial sobre se os trabalhadores atuais são ainda "proletários"; e à nossa resposta no sentido de que eles o são absolutamente mediante múltiplas privações. Claro que essas privações não são primariamente factos políticos, mas sim efeitos da única revolução autêntica e global que teve lugar na nossa época e que, ao contrário de outra, continua a ocorrer na realidade, como "revolução permanente", a da técnica que continua a ser "neutra em relação ao sistema", ou seja, implantou a sua ditadura no Oeste e Leste, e mantém-se constante mesmo após mudanças políticas repentinas, como se nada tivesse acontecido, ou seja, continua a desenvolver-se freneticamente. Este é o caso quando o nível alcançado pela tecnologia, que superou a estrutura política que tem prevalecido até agora, é muitas vezes a força motriz da revolução política. Talvez as revoluções conhecidas da nossa época, que enquanto políticas se apresentaram inclusive como ações salvíficas, só se tenham travestido e no melhor dos casos, só tenham sido mal interpretadas como tais. Na realidade, as mudanças obedeciam a exigências técnicas; e não seria exagerado afirmar que a política é já ideologia ou, ainda mais, que os programas económicos não são mais do que superestruturas construídas por "technological requirements"; que a ditadura da técnica converteu em escravas as próprias ditaduras sob as quais milhões de pessoas tiveram que viver ou ir levando ou sacrificando as suas vidas.

$O$ que une Washington e Moscovo não é certamente isso que se chama "linha vermelha", mas o facto de que não podem existir sem a tecnologia do telefone (e dos reatores nucleares //108 e... e... e...), o facto de que se encontram sob os ditames da técnica e, respetivamente, dos tecnólogos. Não é um argumento contra a nossa tese que os programas políticos da maioria dos países, apesar da ditadura da técnica prevalecente em toda a parte, ainda se diferenciem profundamente, coisa que é inegável. Estas diferenças procedem antes da situação política, social e económica em que a técnica se foi introduzindo. No entanto, uma vez que o tenha feito, cada dia é menos válido dizer-se que tem menos importância que se desenvolva dentro do âmbito político, pois o que a partir daí se dá é uma mudança real, a saber: a importância da técnica é tão predominante que, no fim de contas, qualquer acontecimento político se joga dentro da sua estrutura. De acordo com isso resulta que os estados, procedentes de diferentes passados, se vão assemelhando cada vez mais quanto mais se prolonga o domínio da técnica (que vai aumentando sem parar). Seria insensato esperar que as não-liberdades (antes descritas) desapareceriam com o fim do capitalismo (que talvez chegue algum dia), pois são consequências da técnica numa medida muito maior que as relações de propriedade. Talvez se tenha de perguntar até o contrário - coisa que, naturalmente, é uma ocorrência espantosa, deprimente ou provocatória para qualquer crente socialista - se talvez a técnica, que funciona dentro de uma economia planificada programaticamente (e cuja planificação é ditada pelos seus requirements), tende tão pouco para a satisfação das necessidades humanas (coisa que foi a meta original da introdução da planificação) como a economia capitalista cuja meta é o lucro; se, talvez, até mesmo a técnica que funciona dentro de uma economia não totalmente centralizada, mas estruturada de modo plural (que, aos olhos dos planificadores tem de aparecer como uma desordem) não deixa em aberto ainda algumas lacunas e, daí, algumas últimas possibilidades de liberdade 
(se bem que não planificadas por ela, mas sim aceites). Deixar de lado esta pergunta, que também para os meus ouvidos soa arqui-reacionária e escandalosa, porque lhe respondem de maneira afirmativa os porta-vozes da reação (certamente não pelo seu interesse na liberdade dos trabalhadores) demonstraria não só perplexidade, mas covardia. Não importa: a convergência dos sistemas, que está em andamento há tempos (e que certamente não a descobri eu), é imparável. //109 Esta convergência causada pela técnica, é a revolução que está ocorrendo de forma permanente. E move-se não na direção da liberdade do homem, mas na do totalitarismo dos aparelhos. E como peças desse mundo de aparelhos, nós, os homens, somos, na melhor das hipóteses - proletários. Mas com toda a probabilidade, somos algo muito pior do que isso. 


\section{A obsolescência das máquinas ${ }^{15}$

O sonho das máquinas.

O triunfo no mundo dos aparelhos consiste em ele ter eliminado a distinção entre estruturas técnicas e sociais e deixado sem objeto a distinção entre ambas. $\mathrm{O}$ aparelho de uma empresa, para funcionar, tem de coordenar a prestação de cada grupo de trabalho com a dos demais e que contém ele mesmo inúmeros dispositivos físicos (desde o telefone até à máquina de Hollerith), é um "aparelho" num sentido tão literal como aquele físico-técnico, que habitualmente leva esse nome; ou melhor, é esse inclusive num grau mais elevado, pois o ideal do aparelho realiza-se tanto mais plenamente quanto mais energias e desempenhos reúne em si uma estrutura. Na verdade, os particulares aparelhos (em sentido literal) são incapazes de funcionar com sentido quando não são coordenados num todo que funcione como "aparelho"; caso contrário, falta-lhes tanto matéria-prima, como motivo para trabalhar e consumir. O que hoje se chama "ciência empresarial": de acordo com a sua tendência, não mais é que a tentativa de reunir ambos os tipos de aparelhos numa única disciplina. Em qualquer caso, o bom funcionamento dos macro-aparelhos é a condição de bom funcionamento dos micro-aparelhos, que, vistos a partir da perspetiva dos macro-aparelhos, ficam reduzidos ao papel de meras peças de um aparelho. No entanto, exatamente da mesma maneira, cada macro-aparelho, na medida em que queira continuar a funcionar e a fazê-lo bem, também tem que coordenar-se, por seu turno, com outros, no fim até mesmo com todos os demais macro-aparelhos. Mas, por fantástica que possa soar esta consequência, com isto se afirma que os aparelhos têm como meta //111 fundamental uma "situação ideal" em que só exista um único aparelho e ininterrompido, ou seja, o aparelho: esse aparelho que "incorpora e sintetiza" em si todos os aparelhos e no qual "tudo funciona".

Desta forma, alcançámos um dos conceitos-chave da nossa reflexão, porque na verdade o mundo de aparelhos atual só pode ser compreendido ex futuro, a partir dessa ideia final que lhe é inerente. Agora temos que tentar esclarecer essa situação final; pelo menos, a tendência para a mesma.

15 Traduzido a partir de: Anders, G. (1992). Die Antiquiertheit des Menschen. Bd. 2: Über die Zerstörung des Lebens im Zeitalter der dritten industriellen Revolution (pp. 110-116). 4. Aufl. München: Beck [nota dos editores]. 
Se todos os dispositivos estivessem unidos num único - pois nisso consistiria essa situação - a afirmação "tudo funciona" não significa apenas, como até agora, que dentro desse aparelho isolado já não ocorre qualquer falha, mas que para o aparelho já não existiria em absoluto "o exterior" (da mesma forma que também para sistemas filosóficos não tinha existido "o exterior") e que teria conseguido incorporar tudo: incluir em si todas as funções imagináveis, adjudicar a todas as coisas existentes a sua função, integrar em si todos os homens nascidos no seu couto como funcionários seus; em suma: a frase "tudo funciona" desemboca na equação "aparelhos = mundo". Certamente, isso ainda não é hoje o caso; na atualidade os aparelhos estão no caminho para essa equação, mas mesmo que estejam no caminho, hoje já são considerados "candidatos", peças do "aparelho universal" que está em devir.

E não só se veem a si mesmos assim, como também entre eles; e não só entre si, mas também a qualquer coisa existente. Se se esboçasse uma "ontologia dos aparelhos", ou seja, se se perguntasse como os aparelhos vão ao encontro do ente, portanto, o que para eles vale como "ente", a primeira resposta fundamental soaria assim: cada coisa é por eles considerada como peça potencial de um aparelho. Ou, mais precisamente: só o que se encontra apto para ser uma peça de aparelho é registado e reconhecido como "ente". //112

\section{$\S 3$}

Ontologia da pilhagem

Não é que os aparelhos tratem as matérias-primas, as energias, as coisas e os homens como "eles mesmos"; dá-se apenas que se dirigem a eles como quem tem direito sobre eles. Mesmo a fórmula mais universal "há coisas” já não corresponde a nada na sua ontologia; "haver", "dados", data: tudo isso lhes permanece desconhecido. O que não surge como "algo para tomar", como presa, não o classificam como "ente"; as palavras "ente" e "algo que se pode tomar" são intercambiáveis a partir dessa sua perspetiva: "esse = capi". Portanto, "mundo" é o título de uma zona de ocupação virtual; energias, coisas, homens são exclusivamente materiais requisitáveis. Em sentido estrito esses materiais valem para eles como estando já "aí" desde o momento que são submetidos e integrados e, portanto, obrigados a co-funcionar. É indiferente se os dispositivos utilizam as suas presas como matéria-prima, como peças de máquinas em sentido estrito ou como consumidores, pois também a matéria-prima e o consumidor fazem parte do processo das máquinas. Estritamente falando, eles também são "peças de máquinas".

O que certas teorias mecanicistas vulgares do século XIX tinham assumido como descrição da situação fáctica do universo, a saber, que este é um todo que trabalha à maneira das máquinas, converteu-o agora a técnica na sua meta; para ela, o universo deve tornar-se máquina. A lua, que noutro tempo resplandecia amigavelmente e agora se transformou num satélite de televisão, representante de tantas outras peças do mundo não menos explicativas, pode servir-nos de sinal luminoso deste universo que se vai transformando numa máquina. 
Analogamente, a teoria de l'homme machine do filósofo francês La Mettrie - ou seja, a sua tese de que nós, os homens, parecemos máquinas - tornou-se este postulado: nós os homens //113 temos que tornar-nos iguais às máquinas, convertermo-nos nelas, isto é, em peças de outras máquinas maiores, em última instância, da máquina. Todas as máquinas estão de antemão preparadas tendo em vista esta situação final em que já não haverá máquinas individuais, porque todas ficarão diluídas como peças de máquinas no colo da única máquina beatificante. Desde sempre sonharam e ainda continuam a sonhar com esse reino escatológico da beatitude mecânica, pois enquanto permanecem sob a maldição de ter de trabalhar individualmente e em qualquer caso, mesmo sem coordenação e total concordância, não terão atingido a sua prestação ótima e, com isto, o seu destino. Ainda persistem, pois, no estado de "pecado técnico". A fórmula panteísta de Espinoza individuatio sive negatio (estar separado significa ser de um modo incompleto) é o seu credo da miséria. Ou dito menos metafisicamente: uma vez que, por natureza, são expansionistas e integracionistas e, portanto, ardem de impaciência para não deixar sem ocupação qualquer prestação ou, melhor, são de todo o modo incapazes de não assumir funções que poderiam desempenhar, não terão alcançado a sua meta enquanto ainda existam restos - coisas ou homens "excêntricos" - fora da máquina: desleais energias estranhas ou desempenhos que ainda consigam subtrair-se à intervenção dirigista; vazios que continuam a opor resistência à absorção; resíduos que ainda se recusam a entregar novamente o que lhes resta como matéria-prima ou como fonte de energia. Aos seus olhos, o mais pequeno pedaço de mundo ainda por ocupar é um motivo de tormento e qualquer parte do universo, mesmo que esteja a distâncias estelares, é uma ocasião desperdiçada ou, melhor, uma tarefa desaproveitada, um dever desperdiçado e, portanto, uma mancha da infâmia. Só participarão da beatitude no momento em que experimentem que o "hen kai pan" se tornou realidade, que o deus sive machina ressuscite na sua glória, isto é, que a máquina se tenha colocado em marcha e que, então, também elas, as máquinas, degradadas para ser êmbolos, parafusos ou combustível da máquina, permaneçam integradas e funcionem nela sem resistência. //114

\section{$\S 5$}

\section{Domínio totalitário}

A catastrófica periculosidade de semelhante máquina universal é gritante. $\mathrm{Na}$ verdade, se se tornasse realidade a total interdependência de todas as suas peças - coisa que aconteceria com a degradação de todos os aparelhos em peças do aparelho - qualquer avaria de uma peça afetaria automaticamente e, portanto, paralisaria todo o aparelho. Obviamente, à mesma "máquina total" interessa-lhe não se tornar "completamente total", mas manter uma independência doseada das suas peças. A sua máxima totalitária em relação às suas peças soa assim: eu preciso de ti por inteiro, mas em caso de emergência não preciso de ti. Aqui não podemos aprofundar esta "dialética", que pertence à "Sociologia das coisas". 
$\mathrm{Na}$ geração anterior havia um refrão - os $\mathrm{SA}^{16}$ tinham-no usado nas ruas da Alemanha - que soava assim: “... e amanhã o mundo inteiro”. Certamente, pode ser que hoje já não se oiça este tilintante hino ao domínio total; mas se tivéssemos ouvidos adequados ao mundo de hoje, ouviríamos agora estas palavras exatamente como outrora, ou seja, saindo do ruido das máquinas, incluindo da sua atividade hoje muitas vezes silenciosa. Na verdade, este refrão surgiu da oficina da técnica, cujo domínio é agora tão indiscutível como então, se não mais; e ali foi composto muito antes de existir o termo "nacional-socialismo": por horrível que possa parecer, o que os SA fizeram não foi senão recolher o refrão dos lábios acerados das máquinas para, em seguida, intoxicados com o seu veneno, marchar marcando um passo estrondoso, como peças de máquinas, em direção à grande máquina do Estado total. //115

\section{$\S 6$}

\section{Situação final monocrática}

Se houvesse uma "Sociologia das coisas", o seu axioma seria: "Não existe qualquer aparelho individual". Pelo contrário, cada um é um "zoon politikon" e fora da sua "sociedade", enquanto mera coisa-Robinson, seria inútil. O termo "sociedade” não designa apenas algo semelhante a si mesmo, não somente os milhões de aparelhos que funcionam ao mesmo tempo ou a sua soma, mas um correlato que se ajusta morfologicamente ao aparelho, uma casa que o acolhe, o alimenta, o limpa e que se encontra composta de matérias-primas, produtores, consumidores, aparelhos gémeos e canalizações de esgotos - em suma: um mundo circundante. E dado que o perfeito funcionamento do aparelho individual só estaria garantido se o seu "mundo circundante" funcionasse de modo tão impecável como ele próprio, esse mesmo "mundo circundante" apresenta-se ele mesmo como um aparelho. Se um aparelho-Robinson físico (que, como sabemos, é imaginário) se chama "aparelho a" e "mundo" a empresa da qual este se nutre, na qual funciona e dentro da qual trabalha, é que o "aparelho a", para obter um desempenho ótimo, deseja para si um mundo que também é um aparelho, ou seja, um grande aparelho A que o "encaixe" como se fosse feito sob medida ou como um molde, ou seja, que represente o seu complemento e sua ampliação estrutural e funcional. Certamente isso é mais fácil de desejar que de fazer; não, mesmo esse desejo de um aparelho maior que o encaixe de forma ideal tem de permanecer fundamentalmente irrealizável, pois aparelhos individuais (de x ao $\infty$ ) que poderiam reivindicar um monopólio para configurar o mundo em que funcionam, como molde feito à sua própria imagem, tão pouco existem como singulares indivíduos humanos que podem cortar à própria medida 0 mundo como totalidade. Em vez disso, cada dispositivo tem de se conformar com partilhar esse mundo com inumeráveis semelhantes seus (de x ao $\infty$ ). Por isso, a coordenação do aparelho pequeno e do grande só pode ter lugar de maneira realmente perfeita se todos os aparelhos pequenos, num ato de abnegação, formarem um bloco: o da "comunidade popular dos aparelhos"; isto é, se se empenharem em prol do triunfo de um único grande aparelho, em prol do predomínio de uma situação monocrática, na qual todos teriam de rebaixar-se para ser uma mera peça de aparelho e //116 adquirir, através dessa humilhação, a perfeição

${ }^{16}$ Abreviatura de "Sturmabteilung", grupos de assalto [nota dos editores]. 
do seu funcionamento. Por suposto, a luta pela "comunidade popular" ainda não está ganha, mas faz já bastante tempo que está em marcha (em última análise, desde o primeiro aparelho) e provavelmente não pode já fracassar. 


\title{
A obsolescência das máquinas ${ }^{17}$ \\ II \\ 1969
}

\author{
$\S 1$ \\ Expansão das máquinas
}

Recentemente [em 1965] aconteceu nos Estados Unidos algo insólito não só no habitual sentido sensacionalista e das reportagens, mas algo de extraordinária importância para aqueles que tentam entender filosoficamente os problemas da técnica, especialmente os da planificação e centralização. Refiro-me ao colapso da rede de centrais elétricas no nordeste dos Estados Unidos e no extremo sudeste do Canadá, o que teve como consequência a paralisação durante várias horas numa região povoada por milhões de pessoas. O que temos a aprender com este incidente, podemos compreendê-lo se propusermos um par de reflexões sobre a essência da técnica em geral ou, mais precisamente, sobre as máquinas e aparelhos em geral. Sublinho a expressão "em geral" porque se trata de reflexões de natureza fundamental, ou seja, que são independentes da separação do nosso mundo atual em dois sistemas diferentes de economia e de sociedade e, portanto, são válidas tanto num como noutro ou então não o são nem aqui nem ali. Vou resumir as minhas reflexões em dez teses.

Primeira tese: As máquinas expandem-se. É inata a cada máquina individual a "vontade de poder" (se nos for permitido usar aqui metaforicamente a expressão de Nietzsche). Nenhuma máquina tem poder para não se submeter a essa vontade. Quer queira quer não, //118 cada qual aspira a ser maior que ela própria, pois tende a uma situação em que os processos externos necessários para o seu desempenho e manutenção (como manutenção mecânica, entrada de material, fornecimento de energia, a produção do produto, criação de procura, ritmo de consumo, etc.) se desenvolvem também com precisão mecânica; e isto significa, ao mesmo tempo, que esses processos externos em conjunto com os seus devem formar um grande todo funcional único.

Segunda tese: o impulso expansionista das máquinas é insaciável. Suponhamos uma máquina (M 1) que conseguiu anexar o seu "mundo circundante" (ou seja, os processos que a circundam e que são indispensáveis para que ela própria funcione) e assimilá-lo ao seu próprio funcionamento, de modo que agora todos estes processos juntos representam um único complexo funcional de ordem, isto é, uma grande máquina M 2. O que é que se produz no momento da fusão? Resposta: uma repetição. A tendência expansionista através da qual a

17 Traduzido a partir de: Anders, G. (1992). Die Antiquiertheit de Menschen. Bd. 2: Über die Zerstörung des Lebens im Zeitalter der dritten industriellen Revolution (pp. 117-127). 4. Aufl. München: Beck [nota dos editores]. 
máquina M 1 se transformou na máquina M 2, desemboca de novo num âmbito superior, portanto numa dimensão maior. Ora, também a máquina $\mathrm{M} 2$ tende - e não tender para isso não está no seu poder - para conquistar os processos, que são as condições do seu próprio funcionamento, para que funcionem de maneira tão precisa, calculável e mecânica como ela mesma. Em resumo: a máquina $\mathrm{M} 2$ também se expande e se converte numa máquina maior M 3. É supérfluo indicar que esta expansão também entra num terceiro estádio e, logo, num quarto e assim por diante; ou seja, que, em princípio, não existe qualquer limite para a "iteração" desse processo.

Terceira tese: O número de máquinas existentes diminui. Claro, esta afirmação, apresentada isoladamente, resultaria sem sentido: toda a dona de casa, que compra a sua máquina de lavar, como todo o jovem que paga a prestações a sua motocicleta, sabe que 0 número destes objetos aumenta a cada dia; esse aumento é tão rápido que poderíamos falar de uma "explosão de aparelhos" (análoga à "explosão da população"). Mas não formulamos a nossa tese como uma afirmação isolada, mas em conexão com a nossa teoria da expansão. //119 E, neste contexto, não é absurda, porque o que vale para a máquina individual M 1 (que introduzimos como nosso primeiro modelo), a saber, que percorre os estádios 2, 3, 4, etc., é válido de igual modo para qualquer outra máquina. Noutras palavras: cada uma destas máquinas, para trabalhar otimamente, tem que tentar conquistar o seu "ambiente", induzi-lo a assimilar-se nele e formar com ele uma grande máquina, ou então tem que incorporar-se noutra máquina maior (coisa que acontece em 99 por cento dos casos). Nesse sentido, não temos de partir de uma máquina individual, como fizemos antes de maneira não dialética, mas do parque de máquinas, que hoje já trabalham em conjunto (por mais que não se tenham ainda incorporado na máquina total). Se cada uma, como preparação para a sua sobrevivência e melhoria de desempenho, cultivou a camaradagem e a promiscuidade com as demais máquinas (em última instância com todas), obviamente da perspetiva de uma máquina individual M 1, não tem sentido considerar uma máquina individual M 2 como "outra máquina". Portanto, já não se pode decidir onde acaba uma máquina e onde começa outra. Em vez disso, pode-se ou, melhor, há que falar de uma máquina, não de duas máquinas; e precisamente isso significa - quod erat demonstrandum - uma "diminuição no número de máquinas".

Quarta tese: As máquinas "decaem"18. O último estádio do processo dialético resultante do princípio das máquinas ainda não foi alcançado com a diminuição do número de máquinas. A questão não se esgota com o numérico. Em vez disso entra em jogo uma transformação realmente qualitativa dialética: as máquinas mudam por causa da sua imbricação, e até pode dizer-se que se transformam em algo diferente, em algo inferior.

A que nos referimos com isto? Por suposto, não que valham menos que as máquinas de ontem ou que sejam piores a cada dia; pelo contrário, melhoram progressivamente (sempre que a sua obsolescência não esteja planificada). Também não queremos dizer que diminua o prestígio social das máquinas (ou dos seus //120 proprietários), coisa que pode acontecer de vez em quando (possuir um carro já não significa nada), mas não normalmente. Em vez disso, referimo-nos a que as máquinas, precisamente pela sua imbricação e

${ }^{18}$ Em alemão "kommen herunter", que também pode ser traduzido por "degradam-se" [nota dos editores]. 
colaboração, deixam de ser máquinas, “decaem ontologicamente”, ou seja, convertem-se em peças de aparelhos, em peças de grandes máquinas; isto é, resultam inferiores porque a dignidade das peças é inferior à do todo, do qual fazem parte. O que vale para nós, homens, a saber, que quando somos convertidos em meras "rodas de engrenagem" perdemos a nossa personalidade, também é igualmente válido, estranho que possa parecer, no reino das coisas. A uma reificação do homem, agora geralmente admitida (por perversas razões de moda até mesmo por aqueles que colaboram ou promovem a nossa reificação), corresponde uma "reificação das coisas". Ou seja, o número de máquinas, que ainda são na realidade máquinas e não meras "rodas" de uma máquina, é cada dia menor; pelo menos diariamente aumenta este perigo da "perda de autonomia". Em comparação com o que hoje são as máquinas, as máquinas do século passado foram ainda indivíduos solitários e soberanos, para não dizer orgulhosas "pioneiras com personalidade".

Quinta tese: as máquinas convertem-se numa única máquina. Esta reificação não ocorre apenas ocasionalmente ou apenas num único âmbito. O princípio da "iteração", que já encontrámos antes, é válido em todo o reino das máquinas. Com isto se afirma que, quando as máquinas individuais "decaem”, ou seja, se converteram em peças de grandes máquinas, também estas começam a "decair", convertem-se em meras peças de máquinas, em peças de complexos maiores, etc. Não se vê um fim para esta repetição, a não ser que antes apareça um "final" completamente diferente, a saber, o fim atómico apocalíptico do mundo, que elimina absolutamente a possibilidade de repetições. Ou a menos que um dia se alcance o estádio em que todas as máquinas estejam beatificamente "superadas e assumidas" como peças numa maquinaria única, idêntico ao sistema global de produção e funcionem de maneira conjunta como suas peças. Se se desse esta situação, para a qual tendem //121 as inúmeras máquinas atuais, isso não significaria naturalmente que haveria menos maquinismo que hoje. Pelo contrário: então já não existiria nada que não fosse maquinal. Mas significaria que, a não ser essa coisa totalmente maquinal, da qual todos formariam parte, já não existiria qualquer objeto que pudesse ter a pretensão de deixar-se descrever como máquina individual. Hoje não há nenhum aparelho que não sonhe com esta situação final totalitária ${ }^{19}$, em que ele próprio existisse e funcionasse apenas como uma peça de aparelho de uma peça de aparelho de uma peça de aparelho. Pelo menos, cada máquina, se quiser sobreviver, tem de estar preparada para aceitar de bom grado esta situação de completa degradação. O que nos cabe esperar depois de amanhã não é, portanto, só (como acreditávamos no estádio da quarta tese) uma diminuição no número de máquinas, mas diretamente a abolição do plural "máquinas".

\footnotetext{
19 Uso o termo "totalitário" o mais raramente possível, porque julgo que o seu uso se tornou um abuso, tão suspeitoso quanto a coisa que designa. Se uso o termo neste contexto, faço-o para o colocar no lugar certo, i.e. na esfera que lhe compete. É sabido que o termo é usado, na quase totalidade dos casos, por teóricos e políticos que insistem em serem cidadãos de estados não totalitários ou antitotalitários - o que de facto não passa de hipocrisia ou lisonja. Em 99 de 100 casos, o totalitarismo é tido por ser sobretudo uma tendência política ou um sistema político. E é isto que considero ser falso. Ao invés, sustento aqui a tese de que a tendência para o totalitário pertence à essência da máquina e provém originariamente do âmbito da técnica; que a tendência inerente a cada máquina de dominar o mundo, de aproveitar as peças não dominadas parasitariamente, de unir-se com outras máquinas e de funcionar, junto com estas, como partes de uma máquina única total - que esta tendência constitui um facto básico fundamental; e que o totalitarismo político, por mais horrendo que seja, é apenas um efeito ou uma variante do facto básico tecnológico. Se os porta-vozes das mais desenvolvidas potências mundiais afirmam que praticam a resistência ao princípio do totalitário (no interesse do "mundo livre"), esta afirmação resulta num engano deliberado, ou, no melhor dos casos, numa ingenuidade, visto que o princípio do totalitário é um princípio técnico que obviamente não é nem pode ser combatido pelos "antitotalitários".
} 
E agora voltemos ao caso dos Estados Unidos referido no início. Ali ocorreu algo muito estranho, que permite que apareça com uma nova e inesperada luz a tendência que acabámos de descrever: o processo da expansão, que surge da essência da própria máquina, desenvolve-se em direção à "máquina total” e tem de permitir a qualquer pessoa que reflita, ou seja, a toda a pessoa não doutrinária, a colocar a si mesma de novo o problema da "dialética da máquina".

Que aconteceu? Nalguma parte, numa parte de uma peça de aparelho da gigantesca e enormemente estratificada rede, em que estão unidos os aparelhos, nalgum minúsculo canto produziu-se uma falha "minúscula"20, porque errar não é coisa apenas humana. Não, não era minúscula, pois que significa "minúsculo" se se produzem essas consequências? Com esta falha, milhares de máquinas comprovaram que já não eram máquinas, mas apenas peças de máquina, tal como formulámos na nossa terceira tese. //122 O que se tornou realidade, de forma positiva, como colaboração de inúmeras peças de máquina na forma de uma "rede" significou, ao mesmo tempo, negativamente, que cada peça de máquina dependia de cada uma das demais, portanto também da prestação fracassada de cada uma das outras peças de máquina. De repente, a rede inteira sofreu uma falha porque se tinha produzido uma falha numa só peça; de repente, tornou-se claro que o impulso de expansão "inato" nas máquinas, a fusão das máquinas individuais em complexos de máquinas, tinha como consequência, ao mesmo tempo, um aumento da ameaça de cada máquina individual ou, mais precisamente, de cada uma das peças de máquina.

Sexta tese: Quanto maior é a grande máquina, mais seriamente se encontram ameaçadas as suas peças, que haviam funcionado individualmente antes de se unirem. Por causa da falha ocorrida num qualquer canto secundário da rede - aqui limito-me à descrição de Nova Iorque, embora a área da falha tenha sido muito mais ampla - centenas de milhares de pessoas encontraram-se paradas de repente nas catacumbas do metro de Nova Iorque, nos autocarros da IRT e BMT21, parados como se fossem pedras ou mesas e pareciam não ter alguma vez ouvido falar que até então tinham sido considerados e até mesmo comprovados como objetos móveis. Outros contemporâneos, de igual modo milhares, ficaram suspensos, enquanto as profundezas das ruas se obscureciam insolitamente por debaixo dos seus pés, em elevadores de carga paralisados entre o piso número 100 e o asfalto, como se fossem alpinistas que tinham de resignar-se a permanecer entre o céu e a terra, nessa borda a meio caminho até à qual tinham subido. Milhões de litros de leite se azedaram nos supostos frigoríficos, houvessem crianças ou não, porque a validade da física tem prioridade. As salas de operações ficaram às escuras, sem terem em conta se nesse momento havia que coser um coração ou apenas a ferida de um dedo. As calculadoras recusaram-se a somar as receitas do dia, quer fosse dos cêntimos de uma loja de cigarros ou

${ }^{20}$ De maneira análoga, o ligar de um contacto desconectado antes de tempo "sabotou" o lançamento do foguetão Gemini-6 a 12 de dezembro de 1965.

${ }^{21}$ IRT e BMT são abreviaturas de Interborough Rapid Transit e Brooklyn-Manhattan Transit, companhias de transporte privadas que operavam na zona de Nova Iorque [nota dos editores]. 
de milhões. Os filmes feneceram dos ecrãs, e até mesmo as imagens de cadáveres feneceram. Mesmo um condenado à morte teria tido que permanecer sentado na cadeira elétrica: teria podido estar sentado no cadeirão durante horas - nem quero imaginá-lo - vencedor da falha e espantoso triunfador dessa noite assombrada. //123 Em resumo: de repente, o enorme complexo eletricamente conectado da colossal cidade não pareceu outra coisa que uma gigantesca montanha de milhões de imitações de edifícios, máquinas e estabelecimentos ao estilo da pop-art, totalmente destituídos de sentido, feitos apenas "for the hell of it". De repente, tornou-se manifesto ou (pois claro, já se sabia) cada um compreendeu da maneira mais espantosa que já não havia qualquer aparelho como aparelho individual, nenhuma máquina como máquina individual. A fórmula de Gertrude Stein, ridicularizada como vanguardista e como destituída de sentido: "A rose is a rose is a rose", adquiriu de repente sentido aqui, pois deixava claro que já não era válida, que os frigoríficos já não eram frigoríficos, as carruagens de metro já não eram carruagens de metro, as lâmpadas já não eram lâmpadas. Nada era já isso mesmo, porque cada peça se tinha convertido tão exclusivamente num ramo da central que, se esta caísse, cada peça tinha de perder também o seu sentido. Ou porque - e esta formulação não é menos adequada - cada "ramo" tinha-se convertido na central da rede, pois não só ele dependia dos demais, mas também todos estes dependiam dele. Em qualquer caso, ficou claro para todos que o sonho de esperança das máquinas de chegar alguma vez a unirem-se numa máquina total pode encher-nos não só de esperança, mas tem igualmente que encher-nos de pavor.

Noutras palavras: quando se produziu o colapso da rede elétrica tornou-se manifesto que o processo da expansão dado, que esconde em si o perigo de uma paragem ou de uma peripécia, não pode prosseguir numa medida e num grau sempre iguais, de certo modo em círculos concêntricos que se vão expandindo sem parar. De maneira proporcional ao crescimento das máquinas na direção da grande máquina e ao crescimento desta para 0 complexo de grandes máquinas e deste para uma inteira rede de complexos, também cresce o perigo de falha, inclusive de catástrofe. Desde que uma máquina trabalhe relativamente isolada, a probabilidade de ficar infetada pelos defeitos de outras máquinas (ou de infetar com os seus defeitos outras) é muito menor que se estiver associada a outras. A falha de um aparelho solitário permanece relativamente sem consequências. Em contrapartida, se o funcionamento de //124 uma peça de aparelho 1 depende de uma peça de aparelho maior 2 e este, por seu turno, da de outro ainda maior 3, etc., aumenta o perigo que cada peça individual esconde em si, na medida em que é possível que falhe alguma vez. Se é inegável que a peça de aparelho 1 depende do todo da máquina maior ou total em que está integrada também o é igualmente que o todo depende da peça de aparelho e que a possibilidade de sabotagem inerente à peça mais pequena, será tanto maior quanto maior seja o todo de que faz parte.

O resultado disto é a sétima tese: Apesar de integração das peças no todo, a peça tem de proteger-se do todo tanto quanto o todo das peças: a peça, da falha do todo; e o todo, da falha das peças. 
Os comboios elétricos não funcionavam. Os carros, em contrapartida, sim. Que significa isto? Evidentemente as máquinas eram tanto mais seguras quanto mais funcionavam como indivíduos e menos dependiam de uma conexão contínua com outras máquinas. Mas digo “de uma conexão contínua”: porque está claro que tão pouco os carros são aparelhos independentes, já que dependem dos depósitos de gasolina e, portanto, a sua "autonomia" é devida à maquinaria de fornecimento de gasolina e só são "autónomos" de forma temporária, entre um abastecimento e outro. Certamente, isto não significa nada, pois o colapso das gasolineiras (por exemplo, por causa de uma greve) não teria como consequência imediata o colapso do funcionamento das máquinas individuais, uma vez que estas podem sobreviver em certas circunstâncias a uma greve de gasolineiras, sempre que esta dure pouco.

Por outras palavras: ainda que os comboios e o metro estivessem paralisados à espera de voltar a ser peças de máquina e desse modo ser capazes de funcionar, os autocarros e os carros privados, que tinham reservas de energia pelo menos por algum tempo, continuavam a funcionar como //125 se nada tivesse acontecido. Como já temos dito, isso não significa que existam dois tipos de aparelhos fundamentalmente diferentes. Não é que uns trabalhem só como peças de aparelho de um enorme aparelho central e outros, por exemplo os carros, sejam entes autárquicos e que dependam exclusivamente de si mesmos, como se pudessem esperar despreocupados por esse tipo de catástrofes como o colapso da rede elétrica. O assunto não é tão simples. Sem uma rede de abastecimento, que por seu turno depende de importações, que por seu turno depende também das extrações de petróleo, que por seu turno dependem de constelações de poder político, sem tudo isso naturalmente nenhum carro, naquela tarde obscura, teria estado em condições de continuar a funcionar "com energia própria" e com autarquia, enquanto os comboios elétricos estivessem condenados a permanecer parados. Em qualquer caso, há uma conclusão que se pode tirar dessa diferença.

Oitava tese: O grande aparelho, ao qual estão agregados os aparelhos individuais, de maneira que só desempenham nele o papel de peças de aparelho, tem que conceder, durante todo o tempo do seu funcionamento, a cada uma dessas peças uma ração de reserva, uma ração-ponte, que teria de aguentar durante o tempo de avaria do grande aparelho. Ou dito de outra maneira: a central tem de tomar medidas para a possível situação de emergência da descentralização, na qual pode cair: tem de funcionar sempre de modo que, pelo menos temporariamente, resulte supérflua.

Da mesma maneira que não se pode duvidar que a interconexão de todos os estabelecimentos e aparelhos (em que a economia da energia é a que mais progrediu) comportou enormes vantagens, tão pouco se pode duvidar de que, ainda assim, a magnitude do perigo cresce com a magnitude da grande máquina. Quanto maior é o complexo, maior é a catástrofe se aquele falha. Resulta válido não só que as empresas integradas na grande rede possam perigar com esta, mas também o contrário, a saber, que as grandes empresas representam um perigo, de maneira que as empresas um pouco menores talvez pudessem ser mais práticas. Para além de uma determinada magnitude máxima, que haverá que 
ponderar em cada caso especial, os complexos de aparelhos poderiam não ser económicos por serem demasiado arriscados.

Nona tese: Uma das tarefas principais de toda a planificação (e isto significa: da centralização de milhares de atividades e aparelhos, //126 da sua orientação para uma meta única) consistirá no futuro num doseamento da magnitude das grandes máquinas. É muito possível que o melhor aparelho não só não seja o mais pequeno, como tão pouco o maior.

\section{$\S 4$}

Dialética da técnica.

Nas páginas precedentes extraímos consequências da dialética da máquina, que poderiam ser mal-interpretadas (a esse respeito não tenho ilusões); e não só como uma polémica reacionária contra a economia planificada, mas inclusive como polémica contra a técnica enquanto tal, ou seja, como apelo ao "radicalismo ludita". De facto, esta expressão foi utilizada frequentemente em debates sobre trabalhos meus, em ataques procedentes tanto da parte capitalista como da comunista. A esse respeito queria fazer um par de observações.

1. Não basta sublinhar que é preciso utilizar a técnica para fins bons e não maus, para tarefas construtivas e não destrutivas. Este argumento, que se ouve até à saciedade na boca de muitos homens de bonne volonté é indiscutivelmente míope. O que hoje importa perguntar é se dispomos tão livremente da técnica. Não se pode supor simplesmente essa capacidade de livre disposição. Por outras palavras: cabe pensar que o perigo que nos ameaça não reside na má utilização da técnica, mas que é inerente à essência da mesma.

2. Reacionários são aqueles - tanto faz que sejam do Oeste ou do Leste - que têm medo de ser considerados como "radicais luditas". É pueril acreditar que existem províncias livres de autocontradições e da dialética e que precisamente a técnica seja uma dessas províncias. Não deve surpreender muito que os crentes no progresso pré- ou antimarxistas sejam tão ingénuos a ponto de exaltar a técnica em qualquer circunstância. No entanto, os marxistas, que no termo "dialética" respeitam algo mais do que um cartão-de-visita oficial, não deveriam permiti-lo: eles estão obrigados a reconhecer, investigar e combater as contradições inerentes à técnica como tal e, portanto, os potenciais perigos da mesma. //127 Nada mais irrisório que ver nestes perigos algo irrisório e na investigação dos mesmos algo irrisoriamente não-marxista. Desde o momento que Marx responsabilizou pela alienação o aparelho e a técnica da sociedade capitalista e anunciou a autotransformação do sistema capitalista num socialista - não importa se com razão ou sem ela - também afirmou a inversão dialética precisamente a respeito da técnica.

Naturalmente, com a minha crítica à técnica, nada mais distante de mim (e, claro, nada menos em meu poder) que desaconselhar aos povos tecnicamente subdesenvolvidos e oprimidos pela superioridade dos grandes poderes técnicos que embarquem na "aventura da técnica". A atitude face à técnica nos países subdesenvolvidos tem de diferenciar-se por completo da que importa adotar nos países muito desenvolvidos tecnicamente. A ausência da técnica nos países subdesenvolvidos é um perigo incomparavelmente maior que a sua existência. Nestes países, a prevenção contra a técnica, que é válida entre nós, tem de soar como uma loucura. 
Décima tese: Característica da situação atual do mundo é não só a sua divisão no hemisfério capitalista e outro comunista, e também não só o facto de que subdivida num âmbito muito desenvolvido tecnicamente e noutro atrasado tecnicamente, mas também $o$ facto de os habitantes das diversas regiões muito privilegiadas estarem obrigados a adotar uma posição inteiramente diferente a respeito da técnica. Seria uma loucura colocar sob suspeita a técnica como tal na presença de um indiano faminto, cujo país poderia ser salvo mediante a produção em série de tratores; se o fizéssemos, esse homem teria todo direito de combater-nos como inimigos.

Certamente, resulta difícil responder à pergunta sobre onde é que terá de cessar o sim à técnica e onde é que terá de começar o não, pois esta converte-se numa ameaça não só onde se converte na técnica da ameaça (como ocorre hoje nos Estados Unidos). Uma das principais tarefas da filosofia da técnica será descobrir e determinar o ponto dialético em que o nosso sim à técnica se deve transformar no ceticismo ou num simples e puro Não. 


\title{
A obsolescência da história 22
}

\section{A técnica como sujeito da história}

\author{
A política é o nosso destino (1815) \\ A economia é o nosso destino (1845) \\ A técnica é o nosso destino (1945)
}

\section{$\S 1$ \\ Primeira introdução do conceito de "ahistoricidade". \\ Nem sempre houve história, nem todos os que coexistem no espaço e no tempo são históricos}

Não discuto a afirmação de que o trabalhador atual vive e trabalha de maneira incomparavelmente mais confortável que os seus antepassados. Mas não é realista esperar que esteja consciente desse passado, que não viveu, e do seu próprio fomento, ou seja, da diferença. Vive sem recordações, isto é, ahistoricamente ${ }^{23}$. Gostaria de conhecer o trabalhador a que ocorresse comparar o nível de vida e subsistência dos seus antepassados com o próprio padrão de vida; ou que considere a sua vida como "humanamente digna" ou "não proletária” porque melhor que a dos seus antepassados.

Isso vale também para o pequeno burguês, que surpreendentemente vive de maneira ahistórica, apesar da dimensão dos partidos conservadores a que frequentemente pertence. Contudo, se por acaso se sente com vontade de comparar - utilizo com toda a intenção este vago termo, porque a comparação se dá sempre só de maneira inexata -, não atribuirá mais valor ao presente que ao passado (raras vezes representado concretamente), //272 mas pelo contrário: considerará "os bons velhos tempos" superiores ao presente. E fá-lo inclusive quando o seu passado se fez de uma sucessão de banhos de sangue. Da melancolia que acompanha em geral a memória, vale o que Aristóteles afirmou da existência enquanto tal:

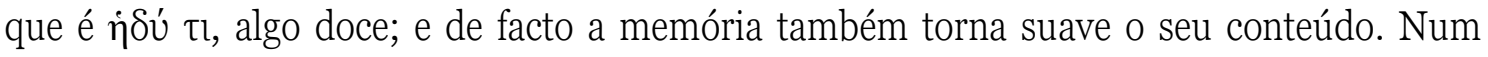
tribunal vienense que julgava criminosos de guerra observei como deixava cair uma lágrima um antigo preso de um campo de concentração durante o seu depoimento sobre os horrores

22 Traduzido a partir de: Anders, G. (1992). Die Antiquiertheit des Menschen. Bd. 2: Über die Zerstörung des Lebens im Zeitalter der dritten industriellen Revolution (pp. 271-298). 4. Aufl. München: Beck [nota dos editores].

${ }^{23} \mathrm{O}$ conceito procede de Marx e Engels. Ambos distinguiam entre povos "ahistóricos" e povos "históricos'”. Consideravam "ahistóricos" sobretudo os povos agrícolas, cuja vida no campo definiu uma vez Marx como "idiota”. Não reconhecia uma história própria à Polonia, que repetidamente tinha sido vítima de "poderes históricos". 
do campo e, como demonstravam as suas palavras, as lágrimas que vertia não eram de tristeza ou indignação, mas de melancolia.

"Mas o homem", assim o assegura um professor americano de college (apesar da maioria dos seus concidadãos conhecerem as suas roots, que mergulham no solo europeu, ainda menos que os meus contemporâneos europeus), "mas o homem é - isso o sabemos pelo menos desde Dilthey - um ser histórico! Vive a partir do seu ontem e anteontem!”

Pode ser que o homem atual ainda esteja marcado mais ou menos pelo seu passado imediato ou remoto, isto é, pelos seus antepassados, pela sua religião e pelos seus costumes. Certamente, antes menos do que mais, pois está marcado sobretudo pelo presente (não considerando o ontem, que ele próprio ainda viveu). Mas mesmo supondo que esteja marcado pelos seus antecedentes, essa relação causal não é em absoluto uma relação de memória. Isto significa que não se pode dizer que quem assim está marcado leve consigo as imagens do que o marcou ou que compare ou até só possa comparar a sua atual existência com essas imagens.

A minha hipótese é que nem todos os seres humanos (isto é, nem todos "os que vivem ao mesmo tempo" no espaço da nossa história, que se poderiam chamar "coespaciais" melhor do que "com-temporâneos") são históricos. E o que vale para o presente vale também para o passado: nem a consciência do ser histórico nem o conceito da história existiram sempre. Inclusive tão pouco houve sempre o objeto do conceito "história”, ou seja, o processo mesmo da história ${ }^{24}$. Por absurdo que possa soar, também o aparecimento deste processo dependeu sempre de certos pressupostos (que só com reservas cabe descrever como "históricos"). //273 Um dia (ou para sermos mais exatos: de cada vez) a história surgiu, depois de milhões de anos, de uma massa de tempo historicamente neutra (na qual estão condenados a permanecer todos os seres vivos exceto o homem) ou de um ciclo de tempo (evidente para os antigos e certamente, também hoje, para alguns campesinos). Contudo, se digo "de cada vez" é porque a história foi até hoje histórias (da mesma maneira que a língua, línguas) e porque só hoje, mediante comunicação dos povos e ao encolhimento diário do mundo, se converte de facto em "história universal", que até ontem só tinha existido como vocábulo e só agora começa; na história global do mundo, que só agora nos é reconhecível e temos diante de nós, se não desaparecermos globalmente antes. Que o tempo atual esteja caracterizado tanto pelo início da história mundial como pelo final do ser histórico é um facto cujo carácter contraditório só podemos explicar mais à frente. O tipo das histórias nacionais singulares, que só se tinha dado por muito pouco tempo na "história das histórias", está a ponto de extinguir-se ${ }^{25}$.

De facto, as histórias singulares foram sempre só "fenómenos históricos”, isto é, intermezzi: ou os seus sujeitos recaíram no nunc stans da ahistoricidade, da qual haviam saído, ou desembocaram - o que era regra geral - nas mais fortes correntes históricas de sujeitos maiores da história que os conquistaram.

\footnotetext{
${ }^{24}$ Por estranha que possa soar esta afirmação, continua a ser completamente inócua em comparação com a espetacular tese de Plotino: nem sequer o tempo existiu sempre (Enn. 45, $98 \mathrm{ss}$ ).

${ }^{25}$ Contra esta tendência da história mundial não poderão competir os povos, que só hoje, tratando de recuperar o siglo XIX, intentam lutar pela sua identidade nacional. Os movimentos nacionais árabes e sionistas, por exemplo, são absurdos anacronismos do ponto de vista da história mundial.
} 
$\S 2$

A história é a história da classe dominante.

Os dominados só são co-históricos.

A sociedade que se transforma sem cessar e que apesar da sua transformação continua a ser capaz de rever as fases precedentes e comparar o seu hoje com essas imagens passadas é um dado recente. Tal como nem sempre se deu essa historicidade, também não é necessário que continue a havê-la no futuro. De facto, considero possível que a sociedade atual seja capaz de voltar a perder a sua historicidade, ou seja, voltar a ser ahistórica na medida em que o tenha sido na sua //274 totalidade (coisa muito discutível).

"Na medida em que (historicidade) a tenha tido na sua totalidade": faço esta ressalva porque seria incorreto acreditar que nós, os contemporâneos (inclusive nós, os que vivemos num espaço histórico euroamericano, tão repleto de história) somos "históricos" em geral e na mesma medida, pois a história é uma história de classes. Com isto não me refiro, por exemplo, a que cada classe tenha tido a sua própria história ou que as histórias de classe "contemporâneas" tenham corrido ou corram paralelas umas em relação às outras: isso precisamente nunca foi o caso. Refiro-me antes a que os dominados, por exemplo os escravos, não tenham tido a sua própria história; a que estes, no decurso dos seus destinos, no máximo alcançaram a sua própria história de vez em quando em insurreições, por exemplo em rebeliões, que, como a revolta de Espártaco, de imediato voltaram a desaparecer. Claro que quando as rebeliões se converteram em revoluções e, como na China ou Vietname, foram bem-sucedidas, produziu-se, de facto, uma nova era histórica: a partir das vítimas da história ou de homens somente co-históricos, os rebeldes ou as suas classes transformaram-se em sujeitos da história.

Como se vê, aqui "história", por seu turno, não é entendida só como uma reconstrução narrativa do que ocorreu ("narratio rerum gestarum”), nem tão pouco só como memória do ocorrido ("memoria rerum gestarum"), mas sobretudo como o ocorrido mesmo ("res gestae"). Mais claramente: a classe dominada não é só ahistórica porque não seja mencionada 26 , porque não produza registos escritos (nem próprios nem alheios) sobre a sua "história"; tão pouco porque não tenha uma consciência do passado - o trabalhador urbano não é apenas um citadino desenraizado, mas antes alguém por completo separado, como por um golpe de machado, da forma de vida campesina dos seus antepassados -; ou ainda porque não mantém vivo o seu passado mediante os seus próprios costumes ${ }^{27}$; mas porque não é um sujeito da história cujos destinos foram fases de um desenvolvimento próprio, explicáveis de maneira imanente a uma classe, um facto em que já Marx tinha insistido de maneira penetrante, ainda que com outro vocabulário, quando, para converter o proletariado num ou em o sujeito da história proclamou a formação da consciência de classe //275 como sua tarefa primordial. Se quiséssemos escrever uma história do proletariado,

${ }^{26}$ Brecht, com a sua pergunta sobre quem tinha construído as pirâmides, referiu-se a essa falta de menção e, portanto, à ahistoricidade dos escravos; $e$ com essa referência tratou de restituir-lhes, pela primeira vez depois de seis mil anos, a luz da história que lhes é devida e assim, utilizando uma expressão de Rilke, "salvá-los"; uma ação que, supostamente, não lhes trouxe absolutamente nada.

${ }^{27}$ Já Zola representou magistralmente, por exemplo em Germinal, a falta de costumes (que não deve confundir-se com a não-eticidade), coisa mais surpreendente porquanto a descrição de semelhante "vazio" de um grupo é muito mais difícil do que a de um grupo que funciona dentro de um esquema ético positivo). 
apenas poderíamos apresentar as suas respostas, a cadeia de reações pelas quais respondeu dia após dia e continua a reagir e a responder às ações e situações históricas da classe dominante ${ }^{28}$, sempre que os termos "reagir" e "responder" não contenham todavia demasiada espontaneidade. Até hoje, o proletariado, mesmo que tenha já pertencido à história, só foi “co-histórico". Assim dos milhões de proletários que, por exemplo, na primeira guerra mundial, verteram o seu sangue, não se pode afirmar que, marchando e caindo no campo de batalha, "reagiram" ou "responderam" às ações históricas das classes dominantes; antes que simplesmente obedeceram, tiveram que obedecer, foram vítimas. Essas guerras, em sentido estrito, não foram "suas"; e se se escrevesse uma história do proletariado, não se poderia dedicar um capítulo autónomo à guerra, pois não seria um capítulo relativo à sua autonomia. E isto é igualmente válido prescindindo do facto das classes dominantes dos poderes beligerantes da primeira guerra mundial terem conseguido convencer os proletários de que o que tinham de fazer era também assunto seu²9, que “já não havia partidos, mas apenas alemães", como disse Guilherme no dia 2 de agosto de 1914; após o que, a social-democracia alemã co-aprovou por meio dos seus parlamentares o financiamento da guerra, isto é, atuou da maneira mais lamentável co-historicamente por vergonha de não tomar parte no entusiasmo manipulado. Hitler e Goering foram ainda mais longe que Guilherme, pois não só impuseram ao proletariado obediência, mas além disso exigiram-lhe que selassem a co-historicidade na forma de uma assimilação expressa. E estes primeiros demagogos da era da reprodução - de certo modo quem venceu em 1933 foi a rádio - conseguiram de facto seduzir o proletariado para levar a cabo com entusiasmo a assimilação decretada e, com isso, aparentemente com espontaneidade. A impostura era inteiramente nova, pois consistiu não só na mediação de uma falsa participação, mas também na produção de um "sentimento falso" (correlato da "falsa consciência" de Marx) e, com isso, por seu turno, na produção de um "falso atuar". //276 Noutras palavras: o proletariado junto com as demais classes aclamou o ser co-histórico que lhe foi imposto como a sua própria história; e o número dos que entravam voluntariamente no partido da morte aumentou em centenas de milhares. À classe, cujos partidos têm sido desmantelados, já não só não lhe era permitido reconhecer "quem” era, mas também não lhe era permitido reconhecer "o que é" que teria sido propriamente bom para ela. "Quereis a guerra total?" "Sim!"

Para além disso, a historicidade ou a co-historicidade manifesta-se no ensino da história, que os filhos do proletariado recebem como os demais, pois são alimentados quase em exclusivo com uma história que lhes é estranha, não com a história do sofrimento, ou seja, com a série das humilhações sofridas pelos seus antepassados.

E isto não é tudo, pois inclusive só no melhor dos casos são “apenas co-históricos”. Dizendo isto não nego a participação ininterrupta e inelutável dos proletários no acontecer real de cada momento: também os cavalos, nas batalhas de cavalaria, fazem parte da história mundial. O que afirmo é, antes, que os filhos dos proletários dificilmente

\footnotetext{
28 Provavelmente, isto vale também para o proletariado após a sua “tomada do poder”; isto é, na União Soviética, pois na realidade tão pouco aí é a classe dominante.

${ }^{29} \mathrm{Na}$ segunda guerra mundial a situação foi diferente: a guerra contra Hitler era uma guerra (pelo menos também) no interesse do proletariado.
} 
compreendem ${ }^{30}$ os conteúdos que lhes são transmitidos nos livros de história: é precisamente porque essa compreensão é rara que antes afirmei "no melhor dos casos". Habitualmente, estes conteúdos provocam a indiferença do filho do proletário, coisa que é compreensível, quase justificada, porque não têm a menor relação com o seu próprio mundo, pelo menos não aos seus olhos; e porque o que não possui qualquer referência vital - esta discriminação é uma capacidade positiva da inteligência - tão pouco pode ser percebido ou compreendido, para não falar de que se possa recordar ${ }^{31}$, podendo no máximo ser metido na cabeça à força de repetições ${ }^{32}$; e o que só foi metido na cabeça à força com grande rapidez é esquecido. Por isso falei aqui em particular de filhos de proletários, não de proletários, pois após saírem da escola não voltam a encontrar a história no sentido de "narratio rerum gestarum"; a historicidade dos "dramas televisivos" - as únicas histórias com as quais 99\% da população entra em contacto resume-se a fingimentos: de tais features não se pode dizer que contribuam para a compreensão da história. //277

\section{$\S 3$ \\ O futuro como história. \\ O que significa ser co-histórico com a história da técnica. Esta última converteu-se recentemente na História}

É certo que, de outro ponto de vista, o proletariado é, pelo menos foi, inteiramente histórico. Digo "foi”, porque é muito problemático afirmar que a constatação (que se segue) ainda se refira ao proletariado. O que pretendo dizer é que era histórico não por uma referência retrospetiva a um passado e à conservação dele, mas pela perspetiva de um futuro esperado; isto é, porque a existência que levou até ao presente, na qual não podia ainda viver humanamente, degenerou em pré-história de uma ou, melhor, da era futura da humanidade ou da sociedade sem classes. Qualquer conhecedor, ainda que de modo superficial, da história da história sabe que o quiliasmo do protocristianismo foi o primeiro a fundar o conceito de "história"; e, claro, o conceito de progresso (que inclusive hoje, nos Estados Unidos e na União Soviética, milhões consideram uma evidência natural) foi de igual modo "futurológico". Mas nas primeiras décadas do século XIX, entre 1800 e 1848, essa futurologia foi substituída por uma mentalidade histórica orientada para o passado, e não só no terreno do Estado alemão. Esta mentalidade, por seu turno, foi substituída por um "requiliasmo". De facto, depois do final da primeira guerra mundial, imperava uma expectativa histórica absolutamente messiânica, à qual tão pouco eu, com dezasseis anos, pude subtrair-

\footnotetext{
30 Pode duvidar-se que, a esse respeito, seja muito melhor para os filhos da burguesia.

31 Por certo que o afã de saber do cientista, dirigido aos conteúdos, que propriamente não lhe interessam em absoluto, é uma exceção que não deve menosprezar-se; inclusive tem uma importância filosófico-antropológica. De facto, o homem é o único animal que "se interessa" por objetos que "não lhe interessam em absoluto"; o único que não está "limitado", que gosta de "procurar o estranho"; para não falar de "transcender". Kant, na sua Crítica do juízo, referiu-se a esta tendência com o conceito de "ausência de interesse".

32 Por isso eram e são completamente sem sentido todos os testes de memorização com sílabas ininteligíveis, conglomerados de números e coisas parecidas: não dizem em absoluto nada sobre a memória das pessoas investigadas (certamente muito sobre a falta de inteligência dos psicólogos que realizam os testes). Só as crianças com distúrbios sabem de memória aquilo que não tem sentido (por exemplo, guias de ferrovias). O genérico e indiferenciado afã de saber o novo [Neugierde, a curiosidade] só raramente é afã de saber o antigo [“Altgierde”], isto é, curiosidade pelo que foi. A “onda arqueológica'”, hoje predominante na literatura não ficcional, não contradiz esta tese, pois os objetos desse interesse são substitutivos, o interesse surge quase em exclusivo do medo em relação à dominação do passado recente; em seu lugar situa-se um antiquíssimo passado estranho. As imagens dos assassinos de Auschwitz são recalcadas; no vazio que se produz assim se colocam as imagens de etruscos ou hititas.
} 
me33. Não estávamos orgulhosos do "quão longe havíamos chegado"; pelo contrário, esperávamos e lutávamos pelo “quão longe chegaríamos” amanhã e depois de amanhã.

Fica por saber, claro, se há que atribuir esta inversão de direção da consciência da história à "história do proletariado" ou se haveria que considerá-la ainda como um elemento de co-historicidade, dado que o novo conceito de história não foi ideado pelo próprio proletariado, mas antes "foi-lhe oferecido" pelos fundadores do socialismo que não eram //278 proletários. Com toda a probabilidade trata-se de um acontecimento histórico que pertence a ambas as "histórias", à da burguesia e à do proletariado, de um "overlapping" que representa uma raridade histórica.

\section{$\S 4$ \\ O futuro já acabou}

Naturalmente, em países subdesenvolvidos, a orientação quiliástica para o futuro continua a desempenhar hoje um papel decisivo. Ou inclusive, desempenha-o pela primeira vez. Enquanto "entre nós", na Europa, América e também na União Soviética (se nos abstrairmos das proclamações oficiais obrigatoriamente otimistas e dos discursos dos congressos de partido), o viver com o olhar posto num futuro ideal parece pertencer já ao passado. Se não estamos de todo enganados, "o futuro já acabou". Ou para sermos mais exatos: a nossa atitude em relação à história alcançou, nas últimas décadas, um novo estádio; melhor, inclusive dois, ou seja, um terceiro e um quarto. Como terceiro refiro-me à conceção da história dos raríssimos pregadores no deserto do tempo, aqui e ali, que temem que a humanidade já não esteja na situação do "ainda não", mas na do "apenas ainda"34, e elevam a sua voz perante o apocalipse, tecnicamente possível, para prevenir o seu altamente provável aparecimento. (“Altamente provável”, porque hoje - e isto define a nossa época as possibilidades técnicas são consideradas totalmente vinculativas, já que "facibile faciendum est", isto é, que o que podemos fazer supostamente também temos que fazê-lo e, por isso, também efetivamente o fazemos). Mas não tenho presentes somente estas advertências daqueles que previnem o futuro: esses também entendem o presente todavia como uma "pré-história", não de um "reino futuro", mas do fim, ou seja, como último "aviso" 35 . //279

\footnotetext{
33 O seu último representante foi o esperançado profissional Ernst Bloch, que não se deixou intimidar ou desanimar por nenhum Auschwitz nem qualquer Hiroshima.

${ }^{34}$ Sobre a mesa de um seminário de uma universidade alemã encontrou-se inciso este verso: PRINZIP VERZWEIFLUNG ODER EINMAI. ETWAS ANDERS ernst bloch spricht:

"wir sind noch nicht". ernster als bloch

${ }^{35} \mathrm{Cfr}$. o autor em Endzeit und Zeitenende, págs. 170 ss.
} 
Esta terceira conceção da história, hoje a mais realista, não é supostamente a da maioria da humanidade. Hoje, a mais difundida é uma quarta, estreitamente unida à terceira. Refiro-me ao facto de nós - e por "nós" entendo a maioria dos nossos contemporâneos que vivem em países industrializados, incluindo os governantes desses países - termos renunciado (ou nos termos deixado levar a essa renúncia) a considerar-nos a nós mesmos (às nações, às classes ou à humanidade) como os sujeitos da história; que nos retirámos do trono (ou nos deixámos retirar) e em nosso lugar colocámos outros sujeitos da história ou, melhor, um único sujeito: a técnica, cuja história não é, como a da arte ou a da música, uma entre outras "histórias", mas a história ou, pelo menos, converteu-se em a história no curso da história recente, coisa que se constata da maneira mais terrível pelo facto de o ser ou o não ser da humanidade depender do seu desenvolvimento e da sua aplicação. A bem dizer, a maioria dos nossos contemporâneos só estão conscientes de forma vaga do significado epocal dessa transformação: de facto todos vivem quase exclusivamente em, com, de e para os seus aparelhos (ou os dos demais) e sem eles já não poderiam continuar "vivendo nem um só instante" 36 . Mas se lhes perguntássemos - na medida em que entendessem esta pergunta filosófica -, definiriam a técnica como algo que se encontra dentro da nossa situação histórica, não como sujeito da história. A isso cabe acrescentar que a irrupção desta nova situação (apesar de, a partir da perspetiva da história universal, ter sido rapidíssima) se produziu (medida com a vara da vida individual) de maneira demasiado gradual para que o indivíduo registasse o que há de revolucionário no acontecimento; e por último, que (como prontamente veremos com um exemplo) o exame do abdicar do trono pelo homem e a entronização da técnica fica ofuscada da maneira mais hábil.

Alguns dos nossos contemporâneos estão, certamente, bem ao corrente da "inversão", visto que tornaram a nova situação //280 no pressuposto, ou seja, no objeto dos seus negócios. Refiro-me aos autores de ficção científica, aos criadores de banda desenhada, que representam acontecimentos interestelares, dos produtores de filmes futurológicos; noutras palavras: dos profetas vulgares do nosso tempo derradeiro, que nos precederam a nós, filósofos, nalgumas décadas. Se por casualidade ouvissem algo de nós, não só compreenderiam o que pensamos, mas aborrecidos fariam desaparecer de cima da mesa a nossa tardia "descoberta", pois faz tempo já que eles reconheceram essa mudança de sujeito como fait accompli e transformaram a sua apresentação em palavras e imagens numa mercadoria rentável, num tempo mesmo em que nós ainda delirávamos com a "essência do homem” ou com “o utensílio à mão", pois era óbvio há décadas que, para nos tornarmos nós mesmos em utensílio à mão (do próprio utensílio), tínhamos que esforçarmos sem cessar; e que, dito heideggerianamente, se há algum “quem da história”, esse “quem” não somos nós, mas precisamente a técnica. E esta tese, válida há anos também vale certamente para a eternidade, ou melhor dito: durante o tempo que ainda nos foi concedido, visto que não nos será concedida a eternidade.

${ }^{36} \mathrm{O}$ movimento Do-it-yourself, o vegetarianismo, a cultura nudista e quanto possa haver de antimecanicismo e rousseaunianismo do pequeno homem são só escapes que confirmam a regra. No resto não se podem levar a cabo sem a ajuda de máquinas: à praia nudista chega-se voando e já a verdura crua se converte em sumo de forma elétrica. 


\author{
$\S 6$ \\ Pastores dos produtos - \\ A técnica é não só o sujeito da história, mas também a sua meta. A produção exige \\ destruição
}

Em estreita conexão com o precedente encontra-se o facto dos homens de Estado, desde Truman a Kissinger e Carter (e os mass-media americanos em geral) quando falam do perigo da destruição (atómica), nunca a designam "end of mankind”, mas em geral "end of civilisation"; ou seja, de que aquilo que aos seus olhos a qualquer preço não deve ser aniquilado e a todo o custo tem que ser conservado não é a humanidade com o seu passado e o seu futuro, mas o mundo dos produtos e dos meios de produção: os carros, as fábricas, os frigoríficos, as plataformas petrolíferas marítimas, os leitores de cassetes, os mísseis intercontinentais, as centrais nucleares... que, se "isso" acontecesse, teriam existido em vão e para nada: uma possibilidade que enche de pânico esses defensores da civilização, //281 porque eles interpretam esse "fim das coisas" como o desperdício máximo e, portanto, como algo imoral37. Por absurdo que possa soar, estão de facto convencidos que a humanidade, à semelhança deles próprios, depende tão estritamente dos seus produtos e meios de produção que lhes resultaria mais difícil suportar essa perda dos produtos e o fim da produção que a sua própria destruição. E o termo "depende" significa não só um "pender de" ou ser dependente, mas também "ser apenas um apêndice"; e isto, por seu turno, significa ser ontologicamente menos importante que aquilo de que se depende. Se, apesar de tudo, esses "tecnocratas" (muito raramente chamados pelo seu nome) consideram digna de ser mantida também a existência da humanidade, é somente porque, aos seus olhos, é preciso que existam proprietários a impedir que os produtos e os meios de produção subsistam ${ }^{38}$ sem dono e sem sentido, ou seja, de maneira digna de lástima, uma ideia que lhes infunde não só pânico mas também compaixão. "Pastores do ser", como Heidegger nos situou, de maneira ainda muito bíblica, isto é, antropocêntrica, e dessa maneira sobrevalorizou com desmesura "o lugar do homem no cosmos" (que se estaria nas tintas para com a questão se ainda estamos nele ou se já desaparecemos dele); não, certamente não somos "pastores do ser". Concebemo-nos, antes, como pastores do nosso mundo de produtos e aparelhos, que, mesmo que seja mais imponente que nós, necessita de nós como servidores (por exemplo, como consumidores ou proprietários). Claro que, nós, enquanto guardiões dos nossos aparelhos, abstemo-nos geralmente de expressar ou até somente de articular mentalmente esta ideia nossa, a ideia que reina na nossa época, de que os nossos produtos são ontológica e axiologicamente superiores a nós, os homens. Esta ideia permanece impensada, pois não reprimimos apenas as pulsões sexuais. $\mathrm{E}$ isso porque de maneira vaga pressentimos que $\mathrm{o}$ nosso alter ego receberia um choque e se escandalizaria. Mas de forma indireta sempre demonstramos o triunfo dessa ideia não pensada, dessa "mentira vital". A prova mais inequívoca desse triunfo é a produção da bomba de neutrões (inventada há uns quinze anos), que trata as nossas fábricas técnicas como tabu e, em contrapartida, a nós como

37 Veja-se a fábula do autor "Das Ende” em Der Blick vom Mond, Munique, 1968.

38 Veja-se a fábula do autor "Die Kanne" em ibid. 
"expendable", formulado em termos teológicos: trata o feito por nós, as opera creata, como mais dignas de sobreviver, como ontologicamente mais importantes que nós, seus criadores, que as fizemos. Em qualquer caso, mediante esta invenção //282 e a declaração feita sem vergonha de que estamos prontos a usá-la, o adjetivo "inumano" adquiriu um sentido que não tinha tido sequer nos anos clássicos da aniquilação, entre 1941 e 1945. Se tivéssemos necessidade de um testemunho derradeiro em prol da "obsolescência do homem", aqui está!39

\section{$\S 7$}

A bomba de neutrões não moderna. A sua inversão. A ahistoricidade dos produtos. "Objetos abortados"

Contudo, mantendo o ideal de economia e conservação herdado dos nossos pais, nós, as pessoas atuais, permanecemos extraviadas de nós próprias. Estou convencido de que inclusive a expressão "conservação cuidadosa das coisas"40 (que, de facto, ainda não ouvi da boca de ninguém com menos de 50 anos) dentro de cem anos soará tão arcaico como hoje o soa a expressão "camareira", pois o nosso princípio atual é o de produzir objetos de usar e deitar fora, conferir aos nossos produtos uma vida curta para criar uma nova necessidade e novos compradores ao conseguir que já não sejam utilizáveis. Assim, pois, aniquilar pessoas não é por certo o primeiro objetivo das armas atuais, coisa que não digo, naturalmente, para fazer a sua apologia, uma vez que genocídios, como os do Vietname ou Camboja, são aceites sem vacilar como efeitos colaterais. Em qualquer caso, o objetivo é o mundo dos produtos (conservado ainda pela bomba de neutrões): este é a atual "Carthago delenda".

O produto ideal de hoje é, portanto, o bem de consumo que, como o pão, se consome enquanto é usado. Todos os produtos atuais tendem e (apesar da publicidade já obsoleta, mas ainda existente sobre a "duração" e "solidez") procuram ser concordes com esse ideal de produto que é a obsolescência, a saber, ter uma vida o mais breve possível ${ }^{41}$. Ora quando já não há nada procedente de ontem, nada que permaneça ou deva permanecer, a história fica abolida. Já faz tempo que o consumidor se adaptou a este ideal da vida efémera, algo que torna manifesto, por exemplo, que compre lenços de papel, que já não tem que lavar. Também os objetos do nosso mundo são, pois, ahistóricos: nem procedem do passado nem estão destinados ao futuro; //283 como os lactantes, vivem só no agora; e muitos não chegam a funcionar, pois antes de verem a luz do dia são substituídos por modelos mais recentes, de certo modo são "abortados" antes do nascimento. Há trinta e cinco anos vivi em Los Angeles esse tipo de "aborto de produtos". Durante a produção de teares de mão, destinados ao hobby, chegou ao patrão de uma empresa a notícia de que em Nova Iorque se vendiam mais baratos uns "hand weaving looms" melhores: a reação foi mandar para o lixo todas as peças já preparadas para ser expedidas.

\footnotetext{
${ }^{39}$ Auschwitz, onde centenas de milhares de pessoas foram classificadas como meras portadoras de cabelo e de dentes de ouro e aniquiladas para se apoderarem do que possuíam, pode-se considerar o campo de prova desta "pura aniquilação humana" (de facto, a bomba de neutrões é recomendada como a "arma mais limpa”).

40 Em alemão "Schonen" [nota dos editores].

${ }^{41}$ A espantosa expansão da indústria conserveira, que parece planificar e produzir não obsolescência, mas eternidade ou, pelo menos, durabilidade, não contradiz a nossa tese. Também utilizamos apenas uma única vez as conservas, que consumimos ao utilizá-las. Não cabe falar, pois, de que "conservemos" canned peaches ou foie gras. O que de facto ganhamos é determinar quase livremente o momento de consumi-los.
} 
Mas deixemos as metáforas. Nos países altamente industrializados vale mais comprar novos objetos que reparar os antigos, coisa que frequentemente é impossível (ou um luxo), pois já não existem reparadores senão para objetos caros como carros, televisores e frigoríficos. Assim, a troca de mercadorias duradouras por mercadorias de usar e deitar fora converteu-se num ganho não só para a indústria, mas também para os clientes. Certamente, essa troca não se realizou sem estranhas convulsões.

\section{$\S 8$}

\section{Usura produzida. Blue jeans}

Faz já quarenta anos que se implantou um movimento que procura acabar com a supremacia dos objetos ahistóricos. Não me refiro só ao florescente comércio de objetos autênticos de um passado e à enorme produção de falsos objetos de um mesmo passado (quase sempre rústico), do qual não procedem a maioria de compradores, por exemplo, placas publicitárias de cafés em ferro fundido, candeeiros a petróleo e coisas parecidas; refiro-me a um fenómeno que é ainda mais dialético: dado que o reparado tem um grande valor pela sua raridade, são "reparados" (inclusive pela própria indústria de usar e deitar fora) e, com isso, são feitos produtos que têm aparência "histórica"; produtos ainda mais dialéticos uma vez que se lhes incorpora "obsolescência", ainda que devam cheirar a passado. Mas assim estamo-nos antecipando.

As encarnações mais notáveis destes novos produtos são as denominadas "Levis", os blue jeans, cuja qualidade consiste //284 na má qualidade produzida artificialmente, que têm de parecer remendados, desbotados e desgastados, isto é, devem simular um passado ou, pelo menos, que são de ontem para serem vendidos e utilizados. "Otherwise they are not up to date" (expressão de uma jovem americana de dezasseis anos, que supostamente não estava consciente do caráter dialético das suas palavras). Os primeiros que compraram e vestiram estas calças tão interessantes do ponto de vista da filosofia da história sentiram-se realmente rebeldes, sabotadores das calças de confeção ahistóricas, detratores da confeção de massas "glossy", manifestantes contra o vinco na calça. Detentores de blue jeans de todo o mundo, uni-vos! De facto, neste novo modo de vestir que dava a ilusão de ser velha havia uma dimensão de "revolução conservadora". Ao mesmo tempo, na medida em que eram usadas pela juventude contestatária de maneira "neutral" em relação a classes e géneros, parecia proclamar uma afirmação da "Equality", um sentimento de "We are the people". Isso parecia, pois, que num ápice a desprezível confeção massificada tinha-se apropriado do outsider contestatário para fazer do novo modo de vestir uma moda coletiva, a cujo ditame já não podia escapar ao fim de pouco tempo qualquer adolescente se não quisesse correr o risco de ser visto pelos outros como membro do establishment. E desde há alguns anos já, tão pouco os próprios filhos dos fabricantes se podem permitir não vestir essas calças anticonformistas, submetida à coerção do conformismo, pois a não o fazerem chamariam a atenção dos demais como não up to date do ponto de vista ideológico ou político, como não pertencentes ao "people" ou, em suma, como indistintos. 
$\S 9$

As armas são bens de consumo. Obsolescência do inimigo.

A guerra e moda como gémeas

Mas voltemos aos produtos de usar e deitar fora, uma vez que a sua encarnação mais proeminente não é em absoluto a moda, mas a indústria bélica, já que esta, mediante constante modernização dos seus modelos, torna inúteis os anteriores, ou seja, mediante a produção destrói: um processo que ainda acelerará com a corrida armamentista das grandes potências. Esta corrida, claro, não agrada do mesmo modo a ambos os concorrentes: a União Soviética e os demais países do Leste, //285 há décadas, por causa da pressão "para manter o ritmo no setor armamentista”, vêem-se obrigados a negligenciar a organização de outras indústrias, ainda subdesenvolvidas. ${ }^{42}$ Em contrapartida, para os Estados Unidos a produção de um novo modelo na União Soviética é bem-vinda, pois anula a capacidade competitiva do próprio modelo americano à data e exige a produção de outro novo - as armas do último ano vendem-se como bugigangas aos estados orientais - e a indústria não pode desejar nada melhor. Nesse ponto, a "guerra fria”, apesar do seu suposto final ainda extraordinariamente quente, era uma situação muito vantajosa para a indústria capitalista. Ora, as maiores vantagens só as oferece, claro está, a guerra "quente", pois as armas, pelo menos os projéteis, as bombas e as armas químicas, formam parte dos "bens de consumo", por estranho que possa soar, pois só se podem utilizar uma única vez. Claro que seria um erro considerar a guerra como uma cesura na vida da indústria capitalista; antes representa só uma continuação da destruição pacífica de produtos com outros meios, para parafrasear a famosa definição de Clausewitz.

A indústria não tende, pois, em primeiro lugar (como poderia fazer-nos crer a produção da bomba de neutrões) para a liquidação do mundo de pessoas e material do inimigo (a que tendem as suas armas), mas dos seus próprios produtos. A estratégia da vitória relâmpago, da imediata e total ruína do adversário, que tinha sido considerada possível e prática há trinta e cinco anos, tornou-se hoje amplamente obsoleta: no plano empresarial seria um mau negócio. O que a indústria prefere agora é a guerra fiável, a guerra com perspetivas sólidas de que dure anos, isto é, a guerra do tipo da do Vietname, que pode acabar inclusive com uma derrota militar (como foi o caso), uma vez que pouco importa que se tenha vencido ou não militarmente, que representa, em todo o caso, uma vitória triunfal do poder da indústria combatente, um consumo máximo de produtos de usar e deitar fora. Visto assim, o Vietname só foi em aparência um inimigo dos Estados Unidos; na verdade, era, quisesse-o ou não, o seu melhor comprador de mercadorias e, com isso, seu aliado mais próximo. Que outro cliente, a não ser semelhante "inimigo", teria //286 oferecido à indústria americana a possibilidade de produzir e consumir o triplo das bombas da segunda guerra mundial? 43 A necessidade de semelhante "inimigo", cliente ou aliado, e de semelhante mentalidade, denominada "patriotismo", que facilita essa relação: essas necessidades

\footnotetext{
42 Isto tem como consequência o facto surpreendente de que, precisamente nos estados socialistas, aquela "conservação" dos objetos quotidianos, sobre a qual antes disse que já tinha desaparecido entre nós, ainda não se converteu em não moderna, isto é, que precisamente ali, como constata surpreendido qualquer visitante, ainda se mantêm as atitudes dos nossos avós.

${ }^{43}$ E vice-versa: os vietnamitas utilizaram as enormes massas de metal, que em forma de bombas choveram sobre o seu país como matériaprima para a sua própria pequena indústria, isto é, utilizaram ao mesmo tempo o inimigo como fornecedor gratuito.
} 
produzem-se não menos de modo artificial que as dos discos estereofónicos ou dos televisores a cores. As fábricas em que se produzem essas necessidades são os mass-media ${ }^{44}$.

Recapitulemos: a modernização dos produtos e a guerra são dois fenómenos gémeos, que se reforçam um ao outro. Ambos servem, cada um à sua maneira, para a destruição dos produtos, que por seu turno garante a continuidade e o aumento da produção. Este aumento é a única coisa que se deseja manter constante e perene. Os produtos, em contrapartida, têm de desaparecer sempre. E o mesmo se passa com os meios de produção, pois a sua permanente utilidade tornaria manifesto o estagnar da produção, para não dizer que, aos olhos daqueles que os produzem, os meios de produção são igualmente produtos e, naturalmente, enquanto tais estão submetidos à lei do uso o mais rapidamente possível e da sua substituição tão depressa quanto possível por outros. O nome do processo aqui descrito continua a ser "progresso" 45 , um conceito que de facto, tanto no Ocidente como Leste, superou da maneira mais vergonhosa todas as crises e catástrofes do século e é o único polo permanente no fluxo dos fenómenos.

\section{$\S 10$}

\section{O bom Superman como sabotador da verdade}

Mas voltemos ao nosso tema principal. Antes de me dedicar a discutir a finalidade da produção - a sua própria destruição - deparei-me com a novidade decisiva da era atual: com o facto de que, hoje, a técnica se converteu no sujeito da história; de que nós só somos "cohistóricos" com esta história; e, por último, de que o exame desta conversão da técnica em sujeito se encontra habitualmente pouco claro //287

De facto, essa confusão produz-se sem cessar, tanto através da escolha dos vocábulos pelos meios de comunicação como pela dos homens de Estado, que com uma vulgar linguagem filosófica ou de edificação querem fazer-nos crer (talvez inclusive nisso acreditem de verdade, pois é mais cómodo crer numa mentira vital que viver constantemente com ela) que nós somos como sempre os sujeitos da história e que só depende da nossa boa vontade (que supostamente temos) como utilizamos a técnica em cada situação histórica, por exemplo, se utilizamos os "atoms for peace" ou "for war", para dizê-lo com as palavras banais de Eisenhower. O facto de que já a mera produção, a mera posse de, o mero factum technicum ou, melhor, a mera possibilidade de produção represente uma forma de utilização; de que hoje sejam idênticos "habere" e "adhibere", "esse" e "adhiberi";46 ou formulado em termos de filosofia da história: o facto de se afirmar que na nossa época também há técnica seria equivocado e que unicamente correto seria dizer que a nossa época

\footnotetext{
44 Certamente, a intenção de produzir essas necessidades também pode tramar. Há anos vimos como os milhões de telespectadores, que através das emissões da guerra do Vietname propriamente teriam que ser conquistados para a televisão, reagiram contra o programado; e supostamente não só com indiferença, mas com horror e indignação. De facto, o movimento contrário à guerra do Vietname jamais tinha conseguido a força política de choque que efetivamente teve sem a diária oferta televisionada de acontecimentos bélicos. Esta experiência contradiz a caracterização da televisão que fiz no primeiro volume. Evidentemente, os horrores do Vietname vistos pela televisão chegaram aos espectadores não só como "fantasmas"; aquela minha análise precisa de uma revisão.

${ }^{4}$ Após esta exposição da destruição como objetivo da produção é necessário rever a avaliação da bomba de neutrões. Obviamente, esta arma, que protege o mundo de produtos não é tão característica da nossa situação atual como geralmente se considera: talvez até seja mesmo uma perda, coisa que naturalmente não faz melhor em absoluto a sua descoberta e a sua eventual utilização. Mas não me surpreenderia nada que depois de amanhã se descobrisse “a bomba de neutrões negativa”, cujo princípio de discriminação seria contrário ao da bomba de neutrões atual, ou seja, que destruiria em exclusivo produtos - coisa que serviria melhor os interesses da indústria - e que não daria qualquer valor especial à liquidação de pessoas. Hoje já posso ouvir a justificação "humanista” dessa descoberta.

${ }^{46}$ Cfr. Endzeit und Zeitenende, pág. 183.
} 
está constituída (e provavelmente, também concluída) pela técnica: compreender este facto transcende o horizonte dos promotores, construtores, proprietários e usuários. Para estes o homem continua a ser, como sempre, o senhor da técnica e, como é natural, aos seus olhos também sobreviverá como tal.

Agora há uma encarnação dessa mentira do senhor e da sobrevivência segundo a qual a decisão sobre o nosso destino ainda continua a estar nas nossas mãos e não nas da técnica: trata-se de um personagem que desde há décadas - entretanto foi sendo acompanhada por muitos outros - vai pulando por todos os mass-media e cuja popularidade não pode ser sobrevalorizada, pois desempenha o papel principal em cenas do Olimpo infantil e popular (como uma olhadela a qualquer periódico americano o confirma): refiro-me ao personagem de "Superman". Com efeito, este homem, cuja característica é ter a capacidade de voar sem avião e sulcar o espaço como um projétil teleguiado, possui uma omnipotência no universo da banda desenhada, em que o colocou o seu criador. E isto significa que a omnipotência (não fica claro graças a que milagre), que na verdade é inerente à técnica, parece ter retornado ao homem (sempre que o termo "retornar" seja o correto, pois o mesmo homem, por paradoxal que possa soar, jamais possuiu a omnipotência, que outorgou à técnica). //288 De todos os modos, já desde há décadas que qualquer analfabeto (seja pré ou pós-alfabético) pode consolar-se com a ideia de que a omnipotência está nas mãos de um antropoide, de um ser com o qual ele se parece; e qualquer um pode quase identificar-se com a imagem deste herói ou semideus ${ }^{47}$.

Ainda que seja um ser divinamente omnipotente no mundo da banda desenhada, instalou-se no nosso mundo real como um servidor; e, precisamente, como servidor dos tecnocratas, que lhe confiaram a tarefa de obnubilar a destronização do homem, a conversão da técnica em sujeito e o imenso interesse, que eles têm em ambos os acontecimentos. Superman foi criado a pedido destes interessados; é criatura sua, ainda que deva a sua reputação a um desenhador ${ }^{48}$ : este foi o seu pintor da corte. E dado que aqueles que solicitaram o encargo desejam além disso que Superman seja confirmado como técnica convertida em homem (ou, talvez, "permanente") pelos milhões que vivem como escravos do mundus technicus e que estes se identifiquem com ele, retiram-lhe desde o princípio o aspeto negativo, não simpático ou inclusive funesto, que hoje é conforme com a essência inerente à ciência da natureza e aos inventos técnicos: o carácter jânico ${ }^{49}$; isto é, propriedade de ser empregue tanto para propósitos bons como maus. Superman escapa desta mácula; desde o seu "nascimento" apresenta-se como um ser exclusivamente moral. Com os seus meios fantásticos (isto é, realistas, pois a técnica converteu-se em fantástica) sempre tende só para o triunfo do bem sobre o mal, sem perder de vista que a sua conceção

\footnotetext{
47 Pois, sim, podemos chamar-lhe "semideus"; e não só por razões formais, pois tem ao mesmo tempo figura humana e força sobrehumana, mas por razões mais especiais, já que é o correlato do semideus mais importante da Antiguidade: Prometeu; com efeito, como um Prometeu de hoje devolveu-nos (supostamente) o fogo, que se nos tinha escapado das mãos. A classificação é adequada também porque, como qualquer deus ou herói que se preze, veio ao mundo como adulto e desde então não envelheceu. Na medida em que hoje se pode ser "eterno", Superman é-o; isto é, acompanhar-nos-á enquanto a nossa técnica subsistir e, com isso, a humanidade e o mundo.

48 Diferentemente de todas as imagens desde o século XV, Superman também tem em comum com todos os personagens míticos que o seu criador é anónimo. Inclusive se se pudesse saber o seu nome (coisa que seria possível, pois protegeu com um número de copyright o deus criado por ele, honra que antes não se havia outorgado a nenhum deus): para os milhões dos seus admiradores e seguidores, o nome do seu criador resultava irrelevante, pois consideravam que a sua personagem tinha existido desde a sua primeira infância ou, melhor, desde sempre.

${ }^{49}$ Cfr. Endzeit und Zeitenende, pág. 155.
} 
de "bem" e "mal" corresponde aos ideais mais convencionais e pequeno-burgueses da middle-class. Num certo sentido, é não só um segundo Prometeu, mas também um segundo arcanjo Miguel.

Ainda que esta mistura de herói e pequeno-burguês só tenha podido ter lugar nos Estados Unidos, o bastardo encontra seguidores por todo o lado onde haja técnica ou se compita por esta; ou seja, em todo o lado ${ }^{50}$. Durante a minha estadia em Hiroshima, faz vinte anos, nenhuma cena me horrorizou tanto como a de duas raparigas de sete ou oito anos, que, sentadas num banco frente ao famoso lugar onde caiu a bomba, comentavam entusiasmadas um fascículo de Superman

//289 e dessa maneira destruíam ali mesmo a ideia da destruição.

\section{$\S 11$ \\ O imperativo categórico de hoje}

Mas voltemos à questão que deixámos pendente no último excurso, sobre em que sentido ainda hoje somos históricos. Tínhamos antecipado uma breve resposta: só somos "co-históricos". Inicialmente, tínhamos introduzido esta categoria como resposta à nossa pergunta sobre o ser histórico ou não do proletariado. Entretanto, o proletariado perdeu o monopólio sobre esse detestável ser só co-histórico, pois agora todos somos já "cohistóricos", sem que importe a classe a que pertençamos; e já não o somos com a história de outra classe, mas com outra classe de história, a saber: com a história do atual sujeito da história, com a da técnica. Com efeito, o nosso papel histórico a respeito da história da técnica não é outro que aquele que foi desempenhado pelo proletariado relativamente à classe dominante. Ou com uma comparação talvez se aproxime mais da verdade: a nossa relação com a técnica não é outra que a do trabalhador particular com a "sua" máquina: da mesma maneira que reconhece a preeminência, a autoridade, o ritmo, etc., desta (deixando de lado o facto de que aqueles que a inventaram eram semelhantes a ele e que poderia tê-la desenhado ele próprio ou, pelo menos, teria podido participar na sua construção) e da mesma maneira que se sente obrigado a ir atrás 51 da máquina, porque esta "vai à frente", também a humanidade agora ou, pelo menos, os cidadãos dos países altamente industrializados sentem-se obrigados a "ir atrás" do nível alcançado pela técnica em cada momento, porque esta "vai à frente". Se hoje existisse um imperativo categórico, não se referiria à nossa relação com os nossos congéneres ou a comunidade ou a sociedade, mas à nossa relação com o status presente ou futuro da técnica. E soaria assim: //290

"Atua de maneira que a máxima da tua ação possa ser a do aparelho, do qual és ou virás a ser parte”;

ou negativamente:

"Não atues nunca de maneira que a máxima da tua ação contradiga as máximas dos aparelhos, dos quais és ou virás a ser parte".

\footnotetext{
${ }^{50}$ Exceto, claro, no mundo comunista: claro que para este sempre foi politicamente insuportável o deus americano, que sempre foi muito solidário com o sistema e, durante a guerra fria, nunca tinha colocado a sua mão sobre a boca, isto é, sobre o balão bd. Desconheço se na literatura de fição científica soviética e polaca, tão florescente e, em parte, tão valiosa, existe um personagem igual ao de Superman, isto é, uma figura da técnica convertida em homem.

${ }^{51}$ Não só em sentido temporal.
} 
Estes imperativos estão em vigor, são aceites quase em todo o lado, por mais que, como é natural, em nenhum lugar se expressem, pois a técnica é fundamentalmente discreta 52 .

\section{$\S 12$}

\section{Ludismo invertido. A retrotradução 53}

É certo que de vez em quando há exceções, situações em que a obrigatoriedade do aparelho não parece estar plenamente consolidada. Denomino "ideológicas" estas situações, porque entre o aparelho que é já de hoje e a moral que ainda é de ontem, existe um desnível que corresponde ao conhecido desnível entre a "base" (já de hoje) e a "superestrutura" (ainda de ontem). Pronto veremos que os homens não poderão manter por muito tempo este desnível e que o "corrigirão”. Mas não nos adiantemos.

Aquilo a que me refiro é o "duplo critério" que frequentemente se pode observar hoje. Um exemplo clássico disto proporcionou-o a guerra do Vietname. Apesar de estar totalmente fora de questão a preeminência do aparelho de destruição em que se encontravam incorporados os G.I. como seus componentes, deles se esperava e se exigia, em contrapartida, que ainda fossem um pouco fiéis a postulados de comportamento anteriores, "pré-técnicos", isto é, que na sua atuação direta se comportassem de modo diferente dos aparelhos; de modo diferente de como teriam podido ou, melhor, devido comportar-se indiretamente, ou seja, como equipas ao serviço dos aparelhos interpostos. Assim, por exemplo, aos G.I. não lhes era permitido levar a cabo diretamente e com as suas próprias mãos o que se permitia ou, melhor, se ordenava às equipas de helicópteros com ajuda de bombas e napalm, a saber: exterminar radicalmente os habitantes das aldeias ${ }^{54}$. Ninguém pode manter, em última instância, semelhante desnivel entre moral do aparelho e moral humana. //291 Mas isto não significa, por exemplo, que os homens exijam que o que lhes está proibido, também esteja proibido às máquinas. Se os G.I. - e estou pensando sobretudo no caso epocal de My Lai: o massacre foi denominado diretamente um "incidente" - se irritaram, não foi contra o facto de se permitir mais aos aparelhos que a eles, mas ao contrário: porque a eles permitia-se-lhes menos que aos aparelhos. Eles queriam ser "even"; por isso perpetraram um banho de sangue, que seria de todo falso denominar "sem par", pois parecia-se com os banhos de sangue que os seus aparelhos causavam diariamente, uns massacres que levavam a cabo só porque desejavam equiparar-se aos seus aparelhos. $\mathrm{O}$ imperativo a que obedeciam não soava assim:

"Impede as tuas máquinas de operar segundo máximas que não possam ser as da tua ação”,

mas ao contrário 55 :

\footnotetext{
52 Inclusive a aniquilação dos judeus por parte do nacional-socialismo foi levada a cabo, na medida do possível, de maneira discreta. Mas o facto de que pôde ser levada a cabo e de que contemporâneos normais, gente como os meus vizinhos, podiam matar de forma consciente milhões dos seus semelhantes, resultaria absolutamente incompreensível se não tivessem reconhecido o nosso imperativo.

${ }^{53}$ Em alemão "Die Rückübersetzung” [nota dos editores].

${ }^{54} \mathrm{O}$ "acontecimento epocal" de My Lai hoje, tão-somente três anos depois do ponto álgido da publicidade global, parece já esquecido, ou seja, deposto ou até sepultado mais profundamente que o acontecimento de Auschwitz, que havia tido lugar vinte e cinco anos antes. Para além disso, está claro que já antes tinha havido inumeráveis My Lai e cabe supor que tinha havido outros muitos depois daquele caso famoso. O facto deste ter adquirido tal publicidade foi pura casualidade.

${ }^{55}$ Não se trata de um autêntico imperativo, mas de uma licença, de uma notificação de um direito.
} 
"Faz tranquilamente o que não contradiga as máximas do aparelho em que estás inserido; e reivindica poder atuar assim".

Se chamo ao massacre de My Lai, a partir do qual podemos decifrar a atual situação, epocal é porque a relação homem-máquina alcançou nela um estádio qualitativamente novo. O que perpetrou o piloto de Hiroshima foi um "assassinato de massas indireto"; e igualmente indiretas foram também as ações assassinas dos helicópteros na guerra do Vietname. Em contrapartida, o que ocorreu em My Lai marcou um terceiro estádio, fundamentalmente novo, pois aqui a ação indireta se retrotraduziu em "terms of direct action". "Retrotradução" é, de facto, o conceito chave sem o qual resulta inexplicável o ocorrido em My Lai.

O estádio que a relação homem-máquina alcançou pode aclarar-se completamente se se compara com ele o que havia representado o ludismo no século XIX. Os luditas se rebelaram contra o mundo das máquinas como mundo prepotente que entrava em competição com eles, ao passo que os assassinos de massas de My Lai aceitaram a sua existência como legítima ou, melhor, como critério de medida natural, precisamente como todos nós aceitamos como natural o mundo das máquinas simplesmente por causa da sua potência //292 e do seu carácter imprescindível. Já não somos capazes de desejar ou inclusive só de representarmos um mundo sem máquinas, como ainda puderam fazer os luditas do século XIX. Quem quisesse combater as máquinas (claro que só de maneira verbal, pois fazê-lo na prática resulta impossível faz tempo) entraria em contradição com a sua própria existência diária e combateria contra si mesmo. Não: contra o que se revoltaram os G.I. de My Lai foi o facto deles, que em definitivo formavam parte do aparelho, não terem os mesmos direitos concedidos a este. O seu objetivo não era a ruína das máquinas, mas chegar a ser "sicut machinae", poder também eles fazer o que lhes era permitido. E se estavam indignados moralmente com algo, era só por ainda se lhe imporem ou eles reconhecerem tabus humanos. Não desejavam sobreviver como homens após a desejada morte das máquinas, mas como partes da máquina após a desejada ou, melhor, reivindicada morte do humano. Se nalgum lado tem sentido o meu lema de "a obsolescência do homem" é precisamente aqui: como título de uma atitude negativa do homem em relação ao seu ser homem.

Cinco grupos tiveram algo que ver com o caso de My Lai: a própria unidade que massacrou; quem deu as ordens; as pessoas implicadas no processo; a imprensa, que publicou milhões de palavras a seu respeito; e, por último, o principal imputado, o tenente Calley ${ }^{56}$, que tratou de formular a sua atitude não só nos seus depoimentos processuais, mas também numa autobiografia (certamente "ghostwritten"). Ora, entre os aludidos não houve nem sequer um que tivesse entendido ou verbalizado o fundamental do acontecimento, o que denominámos "retrotradução". E é muito compreensível; não só porque à humanidade, dominada pela técnica, resulta difícil em sumo grau compreender o seu modo de existência (técnico) - estas inibições são incomparavelmente maiores e mais amplas que todas as tratadas e etiquetadas pela psicanálise -, mas também porque - e este tabu é a autêntica

${ }^{56}$ Como é natural, procurou-se endossar a culpa exclusiva a um "little fish", ao mencionado Calley. Mas mesmo que se tivesse sido mais decente a ponto de procurar e imputar a responsabilidade também a patentes superiores, a natureza real do caso, a "tecnológica", não teria sido aclarada com isso. 
razão dessas inibições - ninguém devia ou não lhe estava permitido compreender ou verbalizar esse modo seu de existência; e isto, por seu turno, //293 porque toda a compreensão, para não falar das formulações, teria equivalido a uma crítica fundamental da técnica e, por suposto, essa crítica tinha de permanecer proibida.

Em qualquer caso, nas semanas do processo não se verbalizou nem uma só vez a suspeita de que os que participaram no massacre tinham desejado, da mesma maneira que muitos milhões dos seus contemporâneos, ser "sicut machinae". Só mediante o nosso conceito de "retrotradução" adquire o caso My Lai uma significação histórica e fundamental; só com ele é visível que o tenente Calley representa a atual relação entre técnica e moral de maneira tão exemplar como Eichmann e Eatherly representaram a situação de então, faz trinta e cinco anos.

Recapitulemos o caso: os Calley tinham todos visto diariamente como os componentes da máquina de guerra, em especial os helicópteros, espalhando napalm transformavam aldeias, juntamente com os seus habitantes, num inferno de fogo. A estes componentes da máquina era-lhes permitido ou, melhor, era-lhes devido a liquidação de civis. Aos olhos dos G.I., que no final de contas tinham direito a considerar-se também componentes da maquinaria bélica, devia resultar-lhes não só incompreensível, mas também ofensivo e injusto, que não lhes fosse permitido e requerido fazer o que se lhes permitia ou, melhor, aquilo a que estavam obrigados os demais componentes da máquina; que fosse permitida e requerida a liquidação indireta e, em contrapartida, se proibisse a direta. Não toleravam esse desnível entre o indireto e o direto; era injusto. E assim empreenderam uma ação direta e dispararam da mesma maneira que os seus modelos, os aparelhos de guerra, "indiscriminately". Assim se disse de modo oficial, como se fosse permitido assassinar "discriminately"; assim dispararam "indiscriminately" contra mulheres, crianças e idosos; e provavelmente, nessa selvagem matança, inclusive gozaram satisfeitos de poder sentir-se no fim, por uma vez, "plenos", quando até então se tinham sentido tratados por uma madrasta. Supostamente, dessa maneira não se equipararam aos seus modelos, pois diferentemente das máquinas assassinas o seu massacre fatigou-os ao ponto de, post festum, notar a necessidade inadiável de sentar-se no lugar do seu trabalho, isto é, entre os corpos destroçados das suas vítimas, //294 para voltar a recuperar energias com a ajuda das rações de lunch que levavam consigo.

\section{$\S 13$}

\section{Otaylorismo como princípio político}

Mas essa discrepância entre máquina e homem, que exemplificámos no caso My Lai, é uma exceção. Em geral considera-se inquestionado o postulado de acertarmos o passo pelo nível da técnica, cuja história se converteu em $a$ história. Isto resulta especialmente claro precisamente hoje, quando alcançou o seu ponto culminante a discussão sobre a construção ou a rejeição dos reatores atómicos. Gente como Robert Jungk e eu próprio, que não nos deixamos intimidar pelo "imperativo" que se supõe que leva consigo o nível da técnica em cada momento e que recusamos - pois inclusive isto se exige como natural em todo lado - 
reconhecer já hoje como obrigatório o nível ainda não alcançado (provavelmente nunca alcançável) da técnica de depois de amanhã, somos vituperados pela indústria e pelos políticos, que cuidam dos seus negócios, como "rebeldes" ou caricaturados como "mal sincronizados" - dito numa resenha do meu livro "Endzeit e Zeitenende" - da mesma maneira que um trabalhador é vituperado ou caricaturado ou inclusive despedido por ser considerado "rebelde", se - coisa que por certo jamais acontece - recusa ou se declara incapaz de obedecer a "Taylor", isto é, de manter o ritmo da "sua" linha de montagem. Com isto refiro-me sobretudo ao problema, até agora irresolvido - se acaso é solúvel - dos depósitos do lixo atómico, que só poderíamos superar se pudéssemos ver de maneira profética as mudanças geodésicas dos próximos milénios; e ao facto de que a indústria e os homens de Estado, que cuidam dos seus negócios, peito para fora (não por si mesmos, mas pelas ciências) descrevem da maneira mais estúpida - e cito as palavras de um chanceler na atualidade em funções - os problemas como "resolúveis naturalmente amanhã", pois "na história da humanidade não surgiu nenhum só problema técnico que não tenha encontrado a solução no momento adequado". Assim fundamentam e justificam - a maioria das vezes com o olhar posto nos êxitos políticos quotidianos //295 e do seu partido - as suas medidas sem escrúpulos com expectativas de soluções de inventores no futuro ou de soluções que provavelmente jamais serão encontradas. É preciso ter claro em que é que desemboca algo semelhante: nada menos que na sincronização com um futuro que com toda a probabilidade nunca terá lugar. "Há que estar preparados", foi a conclusão não casual no parlamento do citado homem de Estado.

E de facto, é pela primeira vez que isto acontece, pois nos acertos de passo que até agora vivemos como vítimas ou espectadores sempre se tinha tratado de sincronizações com condições presentes ou, no máximo, planificadas para depois de amanhã; e frequentemente, de sincronizações exigidas ou impostas por uma autoridade, nas quais se havia caído como súbditos ou clientes. Nem uma coisa nem outra é aqui o caso. Aqueles que argumentam assim, como o nosso famoso homem de Estado, ajustam-se a um futuro (imaginário); e dado que eles mesmos se ajustam, tão pouco se pode dizer que estejam submetidos a um instante que os sincroniza, a não ser que se afirme que são obrigados pela técnica a coordenar-se com uma situação técnica futura ou imaginária.

Também se volta a propor a comparação com um processo laboral, pois num certo sentido a corrida contra o tempo que acabámos de esboçar parece-se com a corrida contra o tempo do trabalhador na sua linha de montagem. Os atuais homens de Estado trabalham apressadamente para acompanhar o passo da linha de montagem da história da técnica. E não é só em absoluto um exagero afirmar que o taylorismo, que nos seus primórdios só foi uma forma especial e em particular proveitosa do trabalho industrial, agora se tenha convertido no princípio da história. Os homens de Estado consideram obrigatório o ritmo da "cadeia da história" de cada momento da mesma maneira que os que trabalham na linha de montagem real. Se mostram medo não é pelas consequências imprevisíveis das suas ações (por exemplo, pelas da construção de reatores) ou pela eventual eliminação do género humano (por guerras atómicas ou contaminação do meio ambiente); dado que a sua fantasia é incapaz de exceder-se como exige a realidade atual, isto é, de um modo realista, consideram esses medos exageradamente excessivos, uma expressão com a qual um conhecido crítico tratou de desqualificar a minha exposição da próxima guerra mundial 
//296 e a mim mesmo. Não, se de todo são capazes de ter medo, têm medo de "ficar atrasados historicamente", quando não até excluídos do negócio do mundo e do número dos que contam, ou seja, dos que são capazes de competir. De facto, numerosos políticos atuais - ontem mesmo o chanceler Kreisky - recorreram a este argumento para forçar a construção de centrais nucleares. A ideia de não acompanharem eventualmente o passo, isto é, de permanecerem atrasados, horroriza estes políticos e, portanto, a economia que está por trás deles e os impele (de modo impercetível, mas inevitável, também falam alguns políticos socialistas dessa economia, que não querem ser ou não podem saber que são os seus portavozes); digo que a ideia de poder ficar atrasados provoca nos políticos um horror tão profundo que a denigrem como "imoral" e, segundo a cor política, como "associal" ou "antinacional". Em termos positivos: aceitam como obrigatórios e até como reconfortantes os ritmos e efeitos do desenvolvimento tecnológico, apesar de há muito tais ritmos resultarem insustentáveis e os possíveis efeitos inimagináveis. E, claro, todos nós chegámos a ser como eles, os governados tal como governantes: convertemo-nos em simpatizantes ou seguidores da técnica atual (por vezes, inclusive, em seus precursores). Com a língua de fora corremos atrás dela, que continua a avançar, e prosseguimos essa corrida mesmo quando intuímos que não só se converteu no nosso destino, mas também no nosso fim. Mas tratamos de silenciar essa intuição mediante a nossa afanosa perseguição. Pelo nosso medo de ficar atrasados em relação aos demais acabaremos por ser os últimos e nada "ficará" realmente de todos nós.

\section{$\S 14$}

Somos todos proletários

Teria podido concluir a argumentação com o jogo de palavras, que acabo de formular, mas que não entendo de maneira caprichosa. Contudo, a questão exige ainda uma última ideia: a de que todos nós, quer sejamos patrões ou operários, que vamos morrer no Este ou no Ocidente, //297 durante o espaço de tempo, que ainda nos está concedido, levaremos ou, melhor, levamos uma vida heterónoma; e por isso - estou consciente da mudança profunda do sentido do conceito que comporta este novo uso - todos seremos ou, melhor, já nos convertemos em proletários. Junto à nova contraposição técnicahumanidade, que até agora (exceto nas propostas, ainda inadequadas, do movimento para a proteção do meio ambiente e das ações antinucleares) não levou a nenhuma batalha e muito menos a uma "luta de classes" (em sentido novo), a luta de classes em sentido tradicional tornou-se irrelevante. É de todo improvável que nós, os neoproletários, cheguemos a unirnos alguma vez para domesticar o inimigo comum. É tão improvável porque, tanto faz que habitemos em "cabanas" ou em "palácios", já estamos unidos, pois corremos lado a lado e cabeça baixa ao encontro da paz comum dos cemitérios. 
Mas voltemos à transformação do homem pela técnica. Mediante esta, como dissemos, a humanidade entra não só noutro período da história, mas sobretudo numa situação que só se pode caracterizar como uma ahistoricidade renovada. Dado que cada novo ano ou, melhor, cada novo dia nos confronta com um "novo mundo", a humanidade progride diariamente sem lançar uma olhadela (raivosa ou nostálgica) para trás ou, mais exatamente, continua a progredir sem parar; fá-lo de maneira muito diferente do anjo de Klee, que Benjamin introduziu como figura simbólica e que volta o seu rosto para trás (apesar de, preso pelas suas asas, se ver arrastado pelo furacão da história). A humanidade atual olha tão pouco para trás como para diante; durante o seu voo tormentoso os seus olhos permanecem fechados ou, no melhor dos casos, fixos em cada instante presente.

Inclusive desde que a técnica dispõe de nós, resulta inadequada a afirmação de que vivemos ahistoricamente. A plena verdade é, antes, que a nossa história se transformou numa história sem pausas //298 do esquecimento de cada momento presente, ou seja, numa história que nunca toma consciência de si mesma e não pode esquecer-se de si mesma e, por isso, não é propriamente "história", mas uma mera sucessão inadvertida. Ora, isto significa - e assim volto à ideia com que tinha começado este ensaio - que não tem sentido exigir ao homem atual, para não falar do proletário atual, ao qual "tão bem lhe correm as coisas", que para saber que já não é proletário tem de comparar o seu nível de vida com o dos seus avós. Apesar da abundância atual de livros de história (que só a burguesia lê) não estabelece, não pode estabelecer a comparação. Se se lhes exigisse esta comparação diretamente aos trabalhadores, tropeçar-se-ia com ouvidos moucos e total incompreensão. Por si mesmos, eles não olham para trás. E com exceção de algumas igrejas ou pontes (e nem toda a cidade é tão antiga como Praga; mesmo a vista de Praga não transmite uma visão da vida anterior), nada lhes recorda já o "seu" mundo antigo ou o dos seus avós. O seu passado já não é em absoluto o seu. Atordoados pela massiva quantidade, a rapidez e o ruído das transformações históricas perderam não só o seu desejo, mas também a sua capacidade de recordar. A assim chamada "onda de nostalgia", ou seja, a produção massiva de memória artificial só demonstra que a memória já não funciona "só por si”. O problema do denominado "passado não superado" é muito mais amplo do que habitualmente o consideramos. A exceção é que existam conteúdos que haja que reprimir. Quem fala de "recalcamento" supõe sempre que o vivido trata de emergir do fundo do inconsciente para o piso superior da consciência. Mas nada disso é correto: dado que já não há caves, mas unicamente superfícies do agora, carentes de profundidade ou superioridade, já não é preciso amontoar nada na cave.

Em suma: nós homens tornámos a converter-nos no que sempre tínhamos sido até ao intermezzo, que só durou uns pobres milénios: seres ahistóricos. 


\title{
A obsolescência da história ${ }^{57}$
}

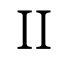

\section{8}

\author{
A obsolescência da modernidade
}

\author{
$\S 1$ \\ A obsolescência da categoria da "modernidade". \\ Hoje todos são modernos
}

Quem, procedente do deslumbrante mundo do exibicionismo e da publicidade, chega às ruas (incluídas também as centrais ruas comerciais) de um Estado socialista - a passagem de Berlim-Zoo para Berlim-Friedrichstrasse é exemplar -, julga não só ter aterrado noutro continente, mas também noutra época. Não, não é no futuro, mas no passado. Esta impressão resulta de se ver transposto para um mundo comparativamente menos mentiroso que, como havia feito o mundo de antes de ontem dos nossos antepassados, não está composto de imagens estimulantes, mas antes de objetos, que da maneira mais sincera "aparecem tal como são" 58 . Este sentimento de regressão parece mais contraditório uma vez que a autocompreensão, proclamada de mil maneiras, dos estados socialistas forma parte da convicção de serem muito mais avançados e "progressistas" que os não socialistas. Ora, ser progressista não é o mesmo que ser moderno. De facto, até há cerca de meio século que o Leste se livrou da categoria de "modernidade" depois de uma erupção de modernidade em inícios dos anos vinte. Isto tem várias causas ${ }^{59}$. Primeira, que a categoria "moderno" só podia ter surgido no mundo capitalista e só neste pôde ter validade. Isto mostra-se claro se se considera a categoria em conexão //300 com a de "moda" (sempre moderna). Dado que o interesse da produção é que a moda dê saída ao maior número possível de produtos, também tem de criar outros novos e inéditos o mais frequentemente possível. O produto P, a princípio, era sedutor pela sua estranheza, ou seja, "moderno"

\footnotetext{
57 Traduzido a partir de: Anders, G. (1992). Die Antiquiertheit des Menschen. Bd. 2: Über die Zerstörung des Lebens im Zeitalter der dritten industriellen Revolution (pp. 299-307). 4. Aufl. München: Beck [nota dos editores].

58 Os colossais arranha-céus de estilo edulcorado que há trinta anos foram erguidos nas capitais do bloco oriental terão de permanecer de pé (pois arquitetura é destino); também ali são considerados testemunhos (especialmente do poder soviético imposto), que já não se quer mostrar; isto é, que assim mesmo tratam de formar parte do passado; contudo, primariamente não foram pensados como objetos publicitários. A sua gestualidade não era tanto a da sedução, quanto a da intimidação. Inclusive os miseráveis ornamentos com que foram adornados de modo kitsch, essas gigantescas bolas de gelado não serviam para a atração, mas tão-somente para a ostentação de poder. Parecem-se com as medalhas com que Estaline (que as tinha atribuído a si mesmo) se deixava fotografar ou, para completar a "cultura", retratar.

59 Por outro lado, também entre nós começa a não ser moderna a categoria "moderno", que apareceu tardiamente no século XIX (em Nietzsche ainda soa moderna) e só continuou a ser "moderna" durante poucas décadas. O título Temps Modernes, que Sartre utilizou no fim da guerra para a sua revista, já era então tão pouco moderno como o título do filme de Chaplin Modern Times. Em vez do termo "moderno", convertido em não moderno, entrou o menos pretensioso "novo". O socialismo não espera um homem "mais moderno", mas um "novo" homem. O conceito "moderno" começou a não ser moderno há já meio século; exemplos: "Neue Sachlichkeit", "nouvelle vague", "new look".
} 
graças à sua novidade no primeiro desfile de moda; logo (no Ocidente cada um tem o seu vestido), é adquirido só por uma elite, que se pode permitir o supérfluo e dessa maneira deseja mostrar-se (e de facto se mostra) como elite; assim, esse produto P é convertido - esta é a mudança dialética - mediante a publicidade num "must", pois ninguém quer ou não pode (por pressão social) deixar de pertencer à elite; isto é, o produto converte-se em algo que ninguém pode deixar de ter, em moda de toda a gente. Quando se alcança esse momento, em que cada um (ou cada mulher) tem o produto, ou seja, o momento da satisfação, produz-se a segunda mudança dialética: os produtores criam não só a necessidade, mas também - coisa que é menos conhecida - o fastio. Há não só uma indústria da publicidade, mas também uma da dissuasão da clientela. Dissuade-se a clientela: "Este vestido (old stuff) já não se pode usar"60. E dado que os primeiros compradores da moda são despojados da sua prerrogativa de chamar a atenção mediante 0 produto P, também acreditam verdadeiramente que "necessitam" de algo novo ou, melhor, dele necessitam efetivamente. Nesse momento concretiza-se o trabalho metódico do produtor para assegurar o processo de produção: enquanto $\mathrm{P}_{1}$ ainda está na moda e continua a ser produzido e vendido: "sobrepõem-se" as fases de $\mathrm{P}_{1}$ e $\mathrm{P}_{2}$. Enquanto ainda publicita $\mathrm{P}_{1}$, projeta $\mathrm{P}_{2}$, que há de substituir $\mathrm{P}_{1}$. E quando esse $\mathrm{P}_{2}$ já está pronto, sofre a mesma sorte que o seu predecessor: converter-se-á em "devido" e imposto a todos, para logo, quando chegue o momento da satisfação, se tornar vítima do fastio produzido pelo seu produtor e ceder lugar a uma terceira geração de produtos. O que é válido para os vestidos vale, mutatis mutandis, para todos os produtos: aparelhagens estereofónicas, carros, metralhadoras, tanques e bombas de napalm. Também estes se convertem (ou: são convertidos), em seguida em não modernos e substituídos por modelos de novas gerações. E essa amortização dos modelos de modelos que nunca se rompe é a história atual, da qual faz //301 parte um prestissimo que ainda não existiu (como frequentemente se assinalou, mas sem uma perspetiva de filosofia da história). Acrescento - e com isto regresso à diferença assim indicada entre a fisionomia do mundo capitalista e a do não capitalista -: estas reflexões de filosofia da história referem-se exclusivamente ao mundo capitalista. É uma obviedade que em eras pré-capitalistas "o tempo avançava com maior lentidão" que hoje, isto é, que a mudança se produzia mais raramente. Mas também num país não capitalista altamente industrializado como a União Soviética o ritmo da história é mais lento que entre nós, apesar da tristemente famosa pretensão de aumentar o ritmo e as metas da planificação. A fabril atividade específica do capitalismo, procedente de que diariamente há que produzir de maneira competitiva não só mais produtos, mas novos tipos de produtos, não existe nos países socialistas, porque aí não é exigida, a não ser que estes países temam perder a competição com os países capitalistas, em especial no setor do armamento. A categoria do ritmo da história não pode ser valorizada suficientemente. As filosofias da história e do tempo continuam vazias desde que não nos oferecem qualquer informação sobre o sistema económico cujo "tempo" investigam, e desde que não nos revelam nada sobre o ritmo do tempo investigado. O tempo histórico não é um "existencial" como também não é uma "forma de intuição". Antes é uma forma da produção, da mudança de produção e do consumo.

${ }^{60}$ Sobre a reação imatura aos blue jeans e o seu princípio: “Só o usado ou, melhor, o gasto é up to date”, veja-se o capítulo anterior, § 7. 
A segunda razão para que a categoria da "modernidade" desapareça nos estados socialistas (ou, se não existiu antes, já não aparecerá) consiste no facto de que "moderno" (pelo menos na boca dos modernos) é um termo conotativo: ser moderno era coisa de uma elite (frequentemente, de uma bohême marginal que se sentia elite), que foi odiada e perseguida pelos "não modernos" com um ressentimento que chegou até à incitação ao progrom 61 . O termo "moderno" entrou no acervo linguístico popular especialmente para definir a confeção, os carros e os frigoríficos; mas não para definir a própria existência histórica ou como nome de época ("a modernidade”). É claro //302 que o momento elitista e, portanto, não igualitário (tanto faz que fosse aristocrático, da bohême ou da intelligentsia), que dependia do conceito da "modernidade", pôde ser tão pouco aceite como ideal de vida pelo socialismo como pelo nacional-socialismo ${ }^{62}$. Mas para as sociedades de massas não socialistas nem fascistas do Ocidente esse "ideal" é de igual modo inaceitável e inutilizável, a não ser que se afirme que na atual sociedade de massas ninguém é não moderno. Um slogan publicitário americano reza assim: "You can't help being up to date". De facto, hoje, para ser não moderno é preciso uma inabitual dose de capacidade de resistência. E isso porque na atualidade cada um, ao ser consumidor por obrigação, participa automaticamente das "aquisições mais recentes" e porque, educado na "planned obsolescence", rejeita que se lhe ofereça o de ontem (repare-se no duplo sentido, ativo e passivo da expressão). Não se pode dizer que participar da modernidade seja ainda uma prerrogativa ou um sinal distintivo; de que ainda haja "ofertas de especial qualidade". Não me refiro só aos blue jeans nem aos last hits da música de entretenimento ou dos gravadores, que nos inundam a casa com o mais trivial "retro" através da técnica mais refinada e "atual", mas também aos "valores culturais" (como tão barbaramente se diz), aos produtos que, em inícios do século XX, quando o conceito de "modernidade" ainda era moderno, se tinham colocado como "modernos" acima de todos os demais: às obras de arte. Hoje já não há ninguém que não conheça os vanguardistas contemporâneos reproduzidos em milhões de cópias e, portanto, consumidos. Estão "in”. E pelo contrário, na atualidade é considerado inconformista e spleening quem não participa do mais recente. Hoje quem não possui os mais novos "musts" chama a atenção e torna-se suspeito da mesma maneira que antes, com a antecipação da modernidade, chamava a atenção como “dandy" e se tornava suspeito. Desde há anos que se me atira à cara como arrogância e sinal de "falta de compreensão democrática" não ter televisão porque não tenho tempo para isso.

A isto cabo acrescentar que na atualidade, por paradoxal que possa soar, cada um tem de estar up to date em relação às obras-primas do passado. //303 Nenhuma escova de dentes sem a "Inacabada", nada de passar o aspirador sem o "Liebestod". É possível que de vez em quando caia uma semente no solo fértil. Esperemos. Mas não está previsto, nem por parte dos produtores nem por parte dos consumidores. A respeito dos produtores: estes isto é o que descobriram há meio século - amam os "valores culturais do passado" tão apaixonadamente porque podem disfrutá-los gratuitamente. Não têm que pagar qualquer percentagem a Telemann ou a Vivaldi, o passado cultural é barato, uma mina de ouro à

\footnotetext{
${ }^{61}$ Sobre este ressentimento especulou o nacional-socialismo, que onde entregou "a modernidade" à ira do povo, era comparativamente insignificante, isto é, na arte (não na técnica).

62 Este converteu em elite o povo inteiro, certamente para enganá-lo; para tal precisou de um pretexto de não-elite, de "piolhos". Como pretexto foram liquidados milhões de escravos e de judeus. A esse respeito, ver do autor Besuch im Hades, Munique 1979, pág. 212.
} 
discrétion. E a respeito das mulheres da limpeza: só lhes interessa que saia algo da torneira acústica, não o quê. Por essas razões, o passado converte-se também em “moderno”.

\section{$\S 2$}

O mais moderno de hoje: o passado produzido converte em moderno

Mas inclusive com isto ainda não se esgotou a dialética da atual situação. Por paradoxal que possa soar, na atualidade, sobretudo nos Estados Unidos, considera-se moderno quem (diferentemente do "man in the street", que vive exclusivamente no agora) pode exibir ou aparentar uma relação com o passado, uma espécie de árvore genealógica: o pseudoaristocrata que se rodeia de objetos rústicos (que sugere a associação "nobreza de província”) ou "continental" (que demonstra cultura). "Fragmentos de cadáver da história" chamou-lhes uma vez Brecht - muito injustamente -, pois não só não se decompõem, como pelo contrário: adquirem um perfume mais doce à medida que envelhecem e se vão convertendo numa possessão mais valiosa de ano para ano, como noutro tempo só ocorria com os violinos ou o vinho, e mais preciosa quando todo a gente sabe que não só custou bom dinheiro, mas no caso de ser vendida terá um valor muito maior que o da sua compra ou, melhor ainda, teriam, pois considera-se de especial prestígio que, apesar do aumento diário do valor do objeto, não se o ponha à venda, não se necessite de o pôr à venda. De facto, quem comercializa estes objetos, os antiquários (diferentemente dos seus antepassados, os comerciantes de roupa velha que iam de lugar em lugar), conseguiram convencer os seus //304 contemporâneos, especialmente os que vivem em países "pobres de história", como a América, de que tudo o que do tempo antigo se conservou de certa maneira se enobreceu com a sua idade e assim é uma obra de arte; de que o valor desses objetos usados é superior ao dos objetos recentes (que, claro, funcionam melhor), porque é um valor de prestígio. Certamente, com frequência, se muda a função dos antigos objetos usados e são integrados na vida do presente, porque nem todos os proprietários, em especial em países com tradições utilitaristas, aprenderam ainda a ver na falta de funcionalidade de um objeto uma virtude e no kantiano "prazer desinteressado" uma atitude distinta e que distingue. Assim, uma vez, em Hollywood vi um móvel da igreja, que não se tinha transformado simplesmente numa obra de arte - o proprietário tinha-se envergonhado de um objeto tão sem finalidade -, mas num móvel-bar eletricamente iluminado. Em qualquer caso, esses objetos estéticos jamais são simplesmente "contemplados"; antes, o "gosto artístico" dos proprietários consiste quase sempre em que é esse gosto que exibe os proprietários. Possuir objetos antigos, cujo aspeto mostre "roots", como se fossem herdados e não comprados, é considerado um sinal de elite e o seu proprietário "moderno", mas de certo modo não porque seja um avangardist, mas porque pode comportar-se como um "aprèsgardist".

Certamente, com isto tão pouco se alcançou o último estádio do desenvolvimento dialético, pois dado que todos desejam fazer parte da elite - a transformação da moda de elite em moda de massas já a descrevemos - e assim, desde há anos, já não se pode satisfazer a procura de objetos "autênticos", irrompeu uma "indústria de antiguidades" que preenche o vazio de mercado com objetos que têm uma aparência mais antiga e autêntica que os verdadeiramente antigos e autênticos. De facto, esses objetos inautênticos, vale dizer, são os 
representantes autênticos da nossa época. Dado que os novos objetos são melhores que os antigos, também os novos objetos antigos são melhores que os antigos. E nenhum convidado para uma party espera que seja realmente autêntica a roca sem sentido que se encontra no living room da sua anfitriã. Pelo contrário: faz já mais de trinta anos, numa dessas partys [sic.], na Califórnia, vi que a anfitriã, ao insistir que a sua //305 antiga roca era realmente "uma velharia", foi considerada não solidária e resultou muito antipática.

Não queria terminar este parágrafo sem contar um caso similar, também na Califórnia. Há trinta e cinco anos em Westwood vi no "art room" com ar condicionado de um Hollywood-would-be-stars, pendurada no teto uma roda (nem a roda sabia se era autêntica ou não) de uma diligência do Arizona (cujo "sentimental value" provém do papel que desempenharam nos chamados westerns); uma roda que a sua proprietária, segundo explicou com sincera desinibição, tinha adquirido num leilão que licitava prestígio e, ainda por cima, por um excessivo preço, já que, como se disse, o traste velho inutilizável alcança preços incomparavelmente mais elevados que o melhor utensílio doméstico atual pela sua raridade real (ou promovida), pela sua capacidade de satisfazer a nostalgia e porque só os endinheirados podem permitir-se o inutilizável. Ali estava pendurada, pois, a roda sem saber onde tinham ido parar os seus milhares de irmãs (se é que era fruto da produção em massa) e perplexa sobre o que tinha que fazer, pois não tinha vontade de continuar a rodar, contra a sua natureza, como a sua parelha, o mobile, na altura ainda bastante desconhecido, apenas entendido como "moderno" e que para ela resultava incompreensível; e aborrecia-se mortalmente. Em resumo: modernismo e conservadorismo (pelo menos, ostentação pública de um passado fingido) não só não se excluem, mas inclusive se complementam; e isto é de facto um modo de "historicidade" peculiar em sumo grau.

\section{$\S 3$}

De novo: não modernidade da categoria "moderno"

Mas voltemos à nossa tese principal de que o conceito de "modernidade" já não é moderno. A principal causa de converter-se em não moderno reside no facto de que a técnica se converteu no único sujeito da história ${ }^{63}$; a técnica, que - coisa em aparência paradoxal só pode ser nova da maneira mais aborrecida, mas não moderna propriamente. De novo, isto vale sobretudo para os estados socialistas //306 do Leste: os seus manobradores ideológicos sempre retiram valor a quanto no Ocidente se denomina "moderno" em cada momento, apelidando-o de exageradamente pretensioso a respeito do gosto, de "formalista", de "burguês", de "degenerado" e, com isso, superado já in statu nascendi e, finalmente, de não progressista ou antiprogressista. E só aceitam obras-primas da arte moderna - as obras de Schönberg e Kafka são representativas de muitas outras - após várias décadas, isto é, só quando já não são “modernas”, mas já ou somente obras do passado, faits accomplis, que, dado que supostamente já não representam nenhum perigo virulento (pois, entretanto, já apareceu outra coisa “mais moderna que o moderno"), não é preciso combatê-las, nem tão pouco podem ser já bem combatidas. Mas os proletários ou os estados socialistas já não utilizam a categoria "moderno" para a compreensão do seu próprio presente histórico e da

${ }^{63}$ Veja-se o capítulo anterior, $\S 3$. 
sua articulação linguística. E inclusive essa expressão “já não" é equívoca, pois ainda parece implicar que nalgum momento utilizaram a categoria - que tinha sido exclusiva da burguesia e da "lumpenbourgeoisie", a bohême - e que entre eles ainda estava viva a recordação do vocábulo. Quanto muito co-utilizaram-na. Por isso, por bonito que possa soar, também é inexato falar de uma conversão da categoria "modernidade" em não moderna, pois esta formulação não excluiria que poderia haver outra coisa ainda moderna e que só ela, a categoria mesma, já não é moderna. Ora, não moderna pode chegar a ser uma moda, uma obra de arte ou um autor só na história das modas que se eliminam umas às outras, mas não há categoria própria de "modernidade". Portanto, aqui trata-se de um desaparecimento que resulta difícil caracterizar do ponto de vista da filosofia da história e que representa um acontecimento fundamental na história das categorias da história ou, se se preferir, na "história da história". //307

\section{$\S 4$}

Modernidade e progresso

Mas voltemos à diferença entre Leste e Ocidente do ponto de vista da filosofia da história. O resumo que podemos fazer é o seguinte: enquanto o Leste, sem estar consciente deste passo, deixou morrer a categoria "modernidade" e rejeita como "não progressistas" muitos artistas e obras do Ocidente, este em contrapartida deprecia (depreciam pelo menos os intelectuais "progressistas" ou vanguardistas, responsáveis pelo aparato categorial utilizado pela sociedade) como "não modernos" os contemporâneos que, ainda hoje, seja na União Soviética ou nos Estados Unidos, reconhecem como válida e continuam a utilizar a categoria "progresso" sem nenhuma desconfiança em relação ao vocábulo e continuam a produzir as suas esculturas e quadros de pouco mérito, entre naturalistas e heroicas, para parques e sedes do partido. Nos jardins de uma cidade da Alta Silésia, em 1965, levaram-me não sem orgulho e solenidade diante uma estátua de bronze de uma jovem de uns dezoito anos que, com expressão vigorosa, brandia uma foice, naturalmente vestida de cima abaixo e, ainda que eu não tivesse nenhuma curiosidade para conhecer essa rapariga, explicaramme que era a "alegoria do progresso". Isso também estava escrito no pedestal, provavelmente para aqueles que não podiam captá-lo de imediato. A donzela estava datada há anos por três razões: primeiro, porque teria podido ser modelada por Begas e ainda não tinha alcançado a modernidade das suas avós, as estátuas de Meunier; segundo, porque estava condenada a ser alegoria de algo; terceiro porque, além de estar provida com um instrumento muito obsoleto e não característico da zona mineira tinha de encarnar precisamente um conceito antiquado. De tudo isso não tinha a menor ideia o meu mentor, que carecia da menor honestidade intelectual; com toda a certeza, não compreendeu o meu suspiro de compaixão: "Pobrezinha!". 


\title{
A obsolescência da história ${ }^{64}$ \\ III \\ 1978
}

\section{O mundo como sereia}

\author{
$\S 1$ \\ A obsolescência dos tabus
}

Ao afirmar que mediante a "planned obsolescence" e a possibilidade da destruição indireta desapareceu a conservação dos objetos antigos, anunciei a obsolescência de uma relação com o mundo. De facto, diariamente se arruínam não só os nossos aparelhos, mas também as nossas atitudes. Assim, por exemplo, através da possibilidade técnica do assassinato indireto de massas (Auschwitz e Hiroshima) e mediante as cenas de torturas e assassinatos entregues en masse em casa pelos mass media, ficou eliminado o horror-tabu frente à violência. O mesmo vale - nisto coincidem todos os etnólogos - para o tabu sexual, o mais antigo e reformulado uma e outra vez, por último em termos cristãos. Este superou-se não só pela produção da pílula, mas também pela produção e venda pública de imagens, filmes e gadgets pornográficos, para não falar das exibições públicas de cenas de sexo, habituais em todo o lado desde há dez anos; em resumo: os produtores destas mercadorias mudaram a função do impulso sexual transformando-o numa procura de mercadorias e, com isso, eo ipso em algo que há que aceitar (pois teria sido um desperdício imperdoável não utilizar como mercadoria algo que pode usar-se como mercadoria). Este desenvolvimento surgiu nos Estados Unidos e alcançou o seu clímax (desde então nunca abandonado) durante a Guerra do Vietname; coisa que é compreensível, pois está claro que para aqueles homens a quem se permitia ou, melhor, se ordenava a diária //309 obscenidade de assassinar, e as famílias back home, às quais se fornecia em casa diariamente, sem o mais pequeno recato, a visão obscena do assassinato..., que a esses milhões não se lhes podia permitir ou cercear a outra oportunidade, a sexual, em comparação completamente inocente. Certamente, ninguém desconhece o facto de que o tabu sexual, depois de milhares de anos de domínio, podia completamente desaparecer em duas ou três décadas. Mas fora de um par de associações de mulheres santarronas, ninguém deixará de reconhecer o que este desaparecimento realmente supõe: uma das revoluções que fazem época na história cultural da humanidade ${ }^{65}$.

É quase supérfluo explicar que a classe dominante está vivamente interessada na libertação, ou seja, na demolição deste tabu também porque assim compra a intangibilidade

${ }^{64}$ Traduzido a partir de: Anders, G. (1992). Die Antiquiertheit des Menschen. Bd. 2: Über die Zerstörung des Lebens im Zeitalter der dritten industriellen Revolution (pp. 308-315). 4. Aufl. München: Beck [nota dos editores].

${ }^{65}$ A referência a Freud como autoridade representa um erro colossal, pois este afirmou o reconhecimento e a observância dos tabus como premissa da civilização. 
do mais interessante, em última instância, para ela: o tabu da propriedade, sempre que aqui se possa falar de "comprar", pois se a demolição do tabu sexual for levada a cabo na forma de venda mercantil, os clientes compram, na medida em que têm desejos de obedecer à oferta, ao passo que para os produtores e comerciantes dos objetos é ao mesmo tempo benéfica a libertação do tabu, com que "compram" a não-libertação do tabu da propriedade. Em qualquer caso, mediante a sistemática liberalização e produção de excitação sexual, o capitalismo mitiga a possibilidade da excitação política e da consciência moral e política. $D a$ mesma maneira que outrora se recomendava o esforço corporal como receita anti-sexual, hoje recomenda-se o sexual com receita antimoral e antipolítica. Não posso esquecer como um teatro de variedades de Nova Iorque, uma semana depois da devastação de Hiroshima, tentava atrair os transeuntes com estas palavras: "Sensational An-atomic Bombs! Step Inside!" Com estas cinco palavras, depois da eliminação da cidade, eliminava-se também o facto dessa eliminação. A superação do tabu, que uma vez - faz já muito tempo - tinha sido revolucionária, pelo menos também se tinha convertido numa medida contrarrevolucionária. //310

\section{$\S 2$}

\section{O mundo sirénico}

Ora, esta sexualização não é um fenómeno isolado no nosso mundo. Antes se converteu na sua qualidade fundamental, pois o nosso é um mundo que publicita e mete em função desta finalidade tudo quanto tem força publicitária. E dado que nada tem mais sucesso publicitário sobre nós que a excitação sexual, o mundo já não se apresenta como "ele próprio", mas como "sirénico". Quem deambula pelos citycenters das capitais mundiais, já não o faz entre fachadas, mas entre lábios, mamas e pernas com vários metros, utilizados como meios publicitários de todo o tipo de mercadorias, também ou, melhor, quase sempre das que não têm o mínimo que ver com o sexo, como por exemplo de pneus de inverno, como há pouco vi em Paris. Estes mostravam a sua qualidade "a peito descoberto" ou, mais exatamente, qualificavam-se com a ajuda de mamas. O nosso mundo, por paradoxal que possa soar, "está vestido de nudez"; esta "nudez" cobre por completo o mundo real que ficou degradado a suporte publicitário. Do mundo capitalista cabe ou, melhor, há que dizer que "já não aparece tal como é", que o seu aspeto autêntico (se é que existe algo assim) está "obsoleto". Enquanto na secção dedicada à obsolescência da aparência mostrava como os aparelhos tratam de parecer menos do que são, quando não mesmo "não aparentar nada", aqui mostro em contrapartida como é que o mundo de mercadorias, mediante o aumento da sua visibilidade, trata de parecer mais do que é, inclusive de conseguir uma visibilidade espetacular enquanto "aparência antecipadora" em imagens do mundo que há que consumir. Em ambos os casos existe uma discrepância entre a coisa e a sua aparência. As coisas do nosso mundo circundante não são visíveis, pois, no mesmo sentido. Antes se dividem em três grupos: o grupo de coisas, que certamente "aparecem tal como são"; o grupo das que "parecem menos"; e por último, o grupo das que "parecem mais". A expressão "aparência antecipadora", cunhada por Bloch para designar a antecipação da felicidade utópica através 
da arte, aqui indica um reclame que precede a mercadoria como um mensageiro deslumbrante. //311

Não se toleram lacunas. Como por encanto, durante a noite revestem-se com reclames as vedações, que cercam as casas em construção. E inclusive numa cidade tão pouco moderna como Viena, os elétricos servem para publicidade móvel de mobiliário e água mineral; que também se pode viajar neles é, em certo sentido, resíduo do passado. Da maneira mais inesperada, o termo "publicitar”66 recupera o seu sentido sexual originário. Só que agora não somos nós os sujeitos da publicidade, mas as mercadorias (melhor, os produtores) que zelosamente vão à caça do cliente, isto é, têm que o encontrar como objetos excitantes. Estão aí, em fila, para conquistar-nos como compradores. Ou se apresentam, dia e noite, como gigantesca revista. Ou, por último - esta terceira metáfora também é adequada - como um enorme mercado de escravos e escravas, que em numerosas cities ocupa muitos quilómetros quadrados. Não ver essas revistas ou esse mercado é não só impossível porque na confusão broadwayesca das metrópoles torna-se impossível "andar descontraidamente pelo bosque", mas sobretudo porque se produziu uma inversão da passividade - isto forma parte da "Teoria do conhecimento da era industrial", ainda não escrita -; com isso refiro-me a que não somos nós que observamos o mundo, mas antes nós que somos observados pelas mercadorias e imagens publicitárias expostas; isso, de forma inexorável, inclusive de forma tanto mais penetrante e desavergonhada, quanto mais artificial é a necessidade que há que estimular. Imagens de pães, que se publicitam e consomem sem mais, não participam no ballet ou, em todo o caso, raramente o fazem; em contrapartida, sempre que há imagens de "mercadorias artificiais", sem as quais se poderia passar sem mais. E nós, que, na qualidade de cidadãos do mundo capitalista, ou seja, como clientes, não podemos evitar parar nesses mercados (pois onde quer que vamos é um mercado), representamos só uma massa de milhões de voyeurs coagidos. Nisso nos converteram os produtores, os proprietários de grandes armazéns e a publicity people: em voyeurs que, ladeados e observados fixamente pelas inevitáveis imagens, não somos capazes de olhar mais além, não somos capazes de tal coisa, não queremos olhar mais além; supostamente uma situação que os produtores só desejam como algo provisório, pois naturalmente esperam ou, melhor, têm como meta exclusiva que consideremos a nossa relação puramente visual só como meio a respeito da meta de substitui-la, com tal rapidez //312 e tão frequentemente quanto seja possível, pela mais real da compra e do consumo ${ }^{67}$.

Não podemos concluir esta descrição sem advertir que essa transformação do mundo num mundo sirénico jamais teria sido possível sem a invenção da luz elétrica. Sem esta, ou seja, à luz do dia, as mercadorias e a publicidade resultam quase sempre só "visíveis", portanto só “aparecem como são"; não sobressaem como o fazem à noite, da obscuridade (ou

\footnotetext{
${ }^{66}$ Em alemão "werben”; que também pode significar "competir", "cortejar” [nota dos editores].

${ }^{67}$ Algumas imagens publicitárias prometem aos voyeurs de profissão, que por razões financeiras ou sexual-patológicas não possam dar o passo para o consumo verdadeiro, isso é, que fiquem fixados eternamente no provisório do mero ver, imagens com que de alguma maneira os satisfazem. Estou a pensar, por exemplo, nas (assim chamadas "stills") fotos expostas como reclames nos cinemas porno, que de certo modo são imagens das "verdadeiras imagens", das "pictures" ou as indicadoras destas (que, por seu turno, estão misturadas com commercial spots, ou seja, com imagens excitantes de outras ou para outras mercadorias). Tanto aos olhos dos produtores como aos dos clientes, a mera contemplação das "pictures" é considerada como seu consumo real. Portanto, os "stills", igualmente imagens, publicitam imagens. Resulta surpreendente que hoje se repita a "iteração da reprodução" que já Platão tinha formulado (claro que com outras intenções): as imagens pintadas do mundo são $\varepsilon l \delta \omega \lambda \alpha$ de $\varepsilon l \delta \omega \lambda \alpha$. (A esse respeito, veja-se a glosa filosófica: "A obsolescência do materialismo".) Faz pouco tempo, numa exposição titulada "História do cartaz" vi imagens publicitárias dos anos vinte que já não tinham uma finalidade (pois os produtos publicitados tinham desaparecido) e assim se tinham transformado em obras de arte. Muitas imagens de conteúdo religioso são como esses cartazes.
} 
de entre mercadoria da concorrência, mais debilmente iluminada), ainda que não inevitáveis. Precisamente da mesma maneira que os seus modelos de duas pernas, as mercadorias e a publicidade têm uma vida noturna; e se Deus não tivesse criado a noite, a indústria publicitária tê-la-ia tido que inventar e produzir.

Certamente, esta vida noturna não é apenas bem-sucedida, pois a luta competitiva que travam entre si as mercadorias só a podem prosseguir, enquanto mercadorias iluminadas ou enquanto reclames luminosos, tratando de deslumbrar-se umas às outras, criando de forma paradoxal um difuso brilho geral, no qual já nenhuma peça pode sobressair. Ou seja que, mediante a sua iluminação, se eliminam umas às outras: uma reprodução exata do mundo capitalista. Em qualquer caso, o papel da eletricidade, em especial das lâmpadas fluorescentes, chega até ao ponto em que transforma não só as mercadorias, sensu stricto, em peças de exposição, mas também em peças da realidade, que assim as converte em mercadorias: edifícios ou, melhor, bairros transformam-se para os turistas em mercadoria para ver, que por seu turno servem de publicidade para as agências de viagem e para a indústria hoteleira. Essas praças iluminadas correspondem às manchetes dos jornais, que convidam a ler a letra pequena. A igreja de São Marcos iluminada, que resplendece com uma magnificência que os seus arquitetos jamais teriam podido imaginar, converte-se em reclame de si mesma. A Chiesa della Salute sobressai no transfundo obscuro da lagoa com uma joia do suporte de veludo sobre o qual é exposto. Mas também isto, certamente, com um sucesso duvidoso, pois como os pósteres que seduziram os clientes a encomendar à sua agência de viagens a sua viagem à "verdadeira Veneza", que tinham visto em casa reproduzida inundada de luz resplandecente, essas igrejas reais apresentam-se a quem ali chega come meras cópias tridimensionais das imagens excitantes, //313 como cópias, diante das quais reagem com aborrecimento e incómodo, o que naturalmente se negam reconhecer. A medicação que utilizam contra esta tristitia post consiste em fotografar as "igrejas obrigatórias", isto é, em torná-las novamente em imagens. Ao "produzir" estas imagens (que, claro, já não se pode chamar "produção", pois o próprio aparelho proporciona tudo o que é necessário) fecha-se o círculo que tinha começado com a imagem do reclame das agências de viagens.

\section{$\S 3$}

O mundo não sirénico do Leste

Mas voltemos de novo do resplandecente Ocidente a Berlim Leste. Não é surpreendente que aqui não estejamos rodeados de reluzentes reclames luminosos, pois quando os clientes vão em busca das mercadorias estas não vão atrás daqueles e onde não há concorrentes, obrigados a silenciar ou a deslumbrar outras mercadorias ou imagens de mercadorias com as próprias, é dispensável a publicidade. Por isso o Leste socialista tem uma aparência tão horrivelmente incolor. E com isto voltamos à dissolução do tabu sexual. Dado que a universalização da excitação sexual, que no Ocidente serve para publicitar tudo, não é necessária, no Leste tão pouco teve lugar obviamente a eliminação do tabu sexual como tal. E isto vale também para a República Democrática Alemã, coisa que sublinho porque o seu público televisivo não pode ser impedido de se informar sobre este 
desenvolvimento e deixar-se infetar por ele. Por estranha que possa soar esta afirmação quem há cinquenta anos se tivesse atrevido a fazer este prognóstico teria sido considerado um louco - ${ }^{68}$ não pode haver dúvida de que os estados socialistas, apesar do seu ateísmo e da sua repressão religiosa, conservaram uma moral sexual das religiões monoteístas, a regra da monogamia e inclusive o conceito de pecado (pelo menos, a má consciência) incomparavelmente melhor que o fizeram os estados capitalistas, que garantem a liberdade das religiões. Responsável por esta moralidade oficial, que domina //314 um terço do globo, é supostamente também o facto de que toda a ortodoxia revolucionária tende ao ascetismo ou, melhor, prescreve-o e impõe-no, pois desconfia do prazer, para não falar da "libertinagem", por ser uma força natural incalculável que põe em perigo a Law and Order, uma revolução dentro da revolução, isto é, por ser anárquica. Na China, supostamente, chegou-se até - e digo-o com cautela, porque a coisa soa de todo o modo incrível - a impor tão profundamente o pudor, que a maior parte dos menores de trinta anos leva uma vida sem sexo. Supõe-se que só se pode "cortejar" a partir dessa idade. E naturalmente, nessa ocasião não por algo mas para algo: a companheira.

Dissemos antes que as ruas do Leste nos parecem antigas e cheias de nostalgia, porque, como no tempo dos nossos avós, têm a "sinceridade" de "parecer como são" e não se prestam a servir de mero transfundo de publicidade. Esta "sinceridade", que realmente não entendemos como virtude, mas como uma consequência de "force majeur", explicámo-la dizendo que onde não existe uma concorrência capitalista nem uma preponderância da oferta sobre a procura torna-se desnecessária a publicidade.

Ora, a nossa afirmação não se pode manter nesta forma categórica. Publicidade, igualmente pomposa, também a há no Leste. No Primeiro de Maio as casas tornam-se invisíveis sob imagens e transparências. Só que aí não se trata:

1. de concorrência contra competidores, que já não existem (a não ser que se considere o mundo capitalista inteiro como o concorrente do mundo socialista);

2. nem de publicidade de mercadorias. O que se publicita é antes a construção do socialismo ou o que se designa com este nome: o seu poder, o seu governo, os seus "clássicos", o cumprimento do plano;

3. nem de publicidade com ajuda de meios de sedução. Não com a ajuda de mamas e pernas se vai à caça da alma, mas com a exposição de instrumentos de intimidação, como foguetes antimísseis (que não "parecem mais" do que são, mas menos) ${ }^{69}$; ou mediante o desfile de fotos de Marx e Lenine (transformados em ícones colossais da maneira mais irrisória); ou com a //315 absurda mostra de textos (talvez, inclusive, plenos de sentido, mas transformados em desmesurados amuletos pré-alfabéticos). Certamente, é inegável que também estas publicidades, que de maneira regular alcançam o seu ponto culminante no Primeiro de Maio, transformam a aparência das cidades socialistas. Mas diferentemente das imagens sedutoras do Ocidente, que têm de mudar diariamente para que sempre estejamos ansiosos e tenhamos curiosidade, as imagens colossais do Primeiro de Maio são as mesmas do ano anterior (mesmo quando um retrato de culto é substituído por outro, permanecem quase os mesmos): por isso carecem dessa força de atração que estimula a curiosidade, que,

${ }^{68}$ Ainda posso recordar que nos primeiros anos após a Revolução bolchevique, em periódicos reacionários da Europa e dos Estados Unidos, esta se identificou com uma "comunidade de mulheres". Mas foi noutros lugares que o "sexo em grupo" se converteu em costume. ${ }^{69}$ Cfr. "A obsolescência da aparência". 


\section{Textos traduzidos}

quer se queira quer não, não se pode negar às imagens sedutoras ocidentais. Tão pouco se dá nelas o efeito antes indicado da mudança de direção, pelo qual as pessoas, em vez de observar as imagens, são observadas por estas. Antes, ambas, imagens e pessoas, ficam aborrecidas e sem olhar ${ }^{70}$. E se nestas ocasiões festivas há algo que impressiona as massas, no máximo é o imponente dessas mesmas massas.

${ }^{70}$ Que os nacional-socialistas conseguiram melhor que os ditadores russos levar a cabo manifestações propagandísticas tem a sua razão de ser em que aqueles puderam recorrer às técnicas de propaganda e exibição do capitalismo e em que eram impostores não apenas por degeneração dos seus princípios, mas por princípio, ab ovo. Das imponentes exibições de massas do filme Metrópolis, produzido pela UFA, ao congresso de Nuremberga ao estilo de Riefenstahl só faltava um passo, coisa que admitiu Fritz Lang, o realizador do bombástico filme da UFA, a quem fiz notar em 1940 a surpreendente similitude. 
Hans Blumenberg 



\section{História do espírito da técnica ${ }^{1}$}

\section{I}

Algumas dificuldades de escrever uma história do espírito da técnica

Cada ciência tem de carregar o peso da sua própria história. Conserva as pegadas da sua história inclusive quando o progresso dos seus resultados parece estar condicionado exclusivamente pelas exigências do seu objeto.

A historiografia surgiu das formas primitivas da crónica. O cronista regista os acontecimentos na ordem de sucessão da sua databilidade ${ }^{2}$, e somente capta o que é datável. Também a forma como na escola topamos pela primeira vez - e a maior parte das vezes com irritação - com a história é, no fundo, a forma própria da crónica. Daí que os acontecimentos de importância histórica sejam, preferentemente, ações humanas datáveis, o que quer dizer que são ações tais que desembocaram em terminados produtos da ação: tratados ou batalhas, governos ou obras legislativas, conquista ou perdas de fortaleza e fronteiras, queda de tiranos ou alterações nas linhas de sucessão.

Quando a historiografia deixou de registar simplesmente de um modo cronológico a cadeia de acontecimentos e passou a mostrar as vinculações entre os elos dessa cadeia, tornou-se patente de seguida que as ações humanas são explicáveis mediante teorias da ação que poderiam ser referidas a elas. Também aqui se seguia salvaguardando a databilidade, na medida em que tais teorias da ação //10 precedem as ações em forma de livros, discursos, proclamações e manifestos e todos estes podem ser fixados, por seu turno, com datas determináveis em que fizeram o seu aparecimento ou se deram a conhecer. As teorias da ação constituem, portanto, elas mesmas, um tipo especial de ações [no manuscrito: acontecimentos], mediante as quais as próprias crónicas podiam enriquecer-se e ser apresentadas dentro de um nexo de correlações compreensíveis.

Só surgiram dúvidas neste esquema quando se julgou entender que para ações no sentido mais amplo podem ser também determinantes pressupostos e condicionamentos extrateoréticos. Podia inverter-se a relação entre os acontecimentos e as circunstâncias dos mesmos. As circunstâncias históricas já não eram unicamente uma consequência e plasmação de determinados acontecimentos históricos, mas que tornavam compreensíveis, por seu turno, os acontecimentos.

Para explicá-lo: uma invenção técnica é, pelo menos nos últimos séculos, um acontecimento datável. E parece que uma tecnificação cada vez maior, como estado próprio das sociedades industriais modernas, não é senão o resultado da soma daqueles acontecimentos de invenção. Karl Marx foi o primeiro a fazer exatamente uma inversão

${ }_{1}$ Traduzido a partir de: Blumenberg, H. (2009). Einige Schwierigkeiten, eine Geistesgeschichte der Technik zu schreiben. In H. Blumenberg, Geistesgeschichte der Technik (pp. 7-48). Aus dem Nachlass hrsg. v. Alexander Schmitz und Bernd Stiegler. Frankfurt/M.: Suhrkamp [nota dos editores].

${ }^{2}$ Em alemão "Datierbarkeit” [nota dos editores]. 


\section{Textos traduzidos}

dessa forma de ver as coisas, no capítulo 13, intitulado "Maquinaria e grande indústria”, do tomo primeiro de [no manuscrito: do seu] O capital. A mecanização da produção é, para ele, a consequência traduzida em inventos, da estrutura do trabalho da primeira manufatura industrial, com a desintegração da produção originariamente artesanal de uma mercadoria nas suas operações laborais elementares. Era precisamente nessa divisão do trabalho que se tornava percetível a possibilidade //11 da mecanização, ficando demonstrado, de um modo, por assim dizer, forçoso a traduzibilidade de um processo laboral elementar num outro processo mecânico. Os inventos não seriam algo que se anunciasse, como se costuma dizer, "no ar", mas que se encontravam já prefigurados no próprio processo do trabalho. Segundo escreve Marx, a oficina de produção dos próprios instrumentos de trabalho - «esse produto da divisão manufatureira do trabalho» - «produz, por seu turno, máquinas». ${ }^{3}$ O modelo deixa patente o que Marx entende por historiografia que valoriza as circunstâncias materiais como condição dos acontecimentos e das ações do espírito, e o que exige de uma «história crítica da tecnologia». ${ }^{4}$

Tal modalidade de historiografia não pode ficar encalhada na tradição das crónicas. O circunstancial subtrair-se-ia à databilidade precisa que determina a relação de fundamentação existente entre teorias da ação e os produtos da mesma. Tinha de considerarse, pelo menos, como possível que as teorias da ação humana não fossem, pela sua parte, senão expressão e consequência de circunstâncias já dadas com anterioridade, podendo, no melhor dos casos, captar, desenvolver e sistematizar as necessidades de ação subjacentes nas próprias circunstâncias, preparando assim talvez e acelerando o surgimento de uma série de acontecimentos, mas sem poder em essência motivá-los. Ora, num contexto assim podia introduzir-se uma profunda desconfiança, que nós, hoje em dia, chamamos "suspeita ideológica": as teorias da ação humana não cimentariam ações dependentes delas, mas não fazem outra coisa senão justificar ações //12 devidas, de todo o modo, aos condicionamentos da situação.

Neste esquema grosseiramente simplificado da problemática de toda a historiografia podem localizar-se as suas dificuldades que emergem para uma história da técnica. Também aqui lidamos com acontecimentos que são mais ou menos precisamente datáveis. Os dispositivos, as técnicas dos procedimentos, os mecanismos, os elementos de construção são descritos em documentos ou conservados como relíquias de museu. A princípio, as dificuldades do historiador da técnica parecem ser menores que as do historiador da política, dado que o âmbito da investigação é delimitável de um modo exato e estrito e as atribuições são nele - pelo menos para o olhar do espectador moderno - de uma lógica objetiva. Em tudo isto se passaria algo semelhante ao que ocorre na história das ciências exatas: os resultados teóricos de uma determinada etapa contêm os problemas que se colocam nos próximos passos do conhecimento. De modo que na história da técnica a solução de um determinado problema de construção torna reconhecíveis, ao mesmo tempo, as carências que ainda têm de ser resolvidas, estabelecendo assim as tarefas para soluções futuras. Quanto mais nos aproximamos aos tempos atuais tanto mais se convertem a história das ciências exatas e a história da técnica - como também a história das artes plásticas e da literatura - em domínios fechados caracterizados por uma lógica interna própria do seu

\footnotetext{
${ }^{3} O$ capital, I 4, 12 .
}

${ }^{4}$ O capital, I 4, 13, nota 89. 
desenvolvimento, tornando-se desse modo relativamente independentes de influências e dependências externas. De maneira que toda a suma complicação da crítica da cultura dos nossos dias, que vai desde uma atitude de otimismo tecnológico até à demonização da técnica, //13 apenas exerce um influxo pouco percetível sobre o próprio processo da tecnificação, por muito que influencia a relação entre o homem e a realidade técnica.

Ora, a questão é se se pode generalizar o modelo de um estado de alta condensação do científico e do técnico. Podemos contar com a lógica interna dos processos objetivos também a respeito dos princípios da época determinada pela ciência e pela técnica? A história da técnica tem de tornar, todavia, compreensível de que classe de impulsos surgiram a organização de uma nova realidade antes dos seus próprios elementos poderem apresentar as exigências do seu desenvolvimento e integração interior. A história da técnica não pode ser nem a mera crónica do aparecimento de novos procedimentos, aptidões e mecanismos nem a história da técnica na história tão enfaticamente buscada hoje em dia: a exposição da soma de todas as dependências da realidade da vida do estado de tecnificação correspondente. A história da técnica terá de ser também, e antes de mais, a história da saída da técnica do âmbito da história. O tema de se - e como - a partir de uma determinada nova compreensão da realidade e do lugar do homem no quadro dessa realidade surge uma vontade de técnica terá de ser o tema de uma história do espírito da técnica que não só reúna e registe autointerpretações da atividade e autoria técnicas, mas que faça com que se tornem compreensíveis as motivações de um estilo de vida que aponta e que se sustenta na técnica.

Tudo isto parece plausível, mas a dificuldade começa quando nos pomos a esboçar esta história do espírito da técnica. //14 Os testemunhos que se oferecem como fontes dão a impressão, à primeira vista, que se podem tornar demonstráveis as motivações dos procedimentos e da produção de ordem técnica. Mas uma análise mais precisa de tais fontes - por exemplo, dos séculos XVII e XVIII - não tarda a despertar a dúvida se aquilo que parece abrir-nos o acesso ao transfundo dos estímulos intelectuais não deverá a sua origem, antes, à necessidade de justificar o que já se tornou realidade. E em vez de um testemunho das origens o que teríamos seriam resquícios de uma ideologia do técnico.

Servindo-me de três exemplos, gostaria de explicar um pouco mais detalhadamente a ambiguidade que aqui se pode gerar.

O primeiro exemplo faz referência ao conceito de invenção, isto é, ao conceito de uma produção originária de uma concreção até agora desconhecida. Na passagem citada de O capital de Karl Marx fica claro que o inventor só parece, por assim dizer, como o funcionário e ajudante de realização do processo objetivo de industrialização. ${ }^{5}$ Mas a insistência no mero carácter reprodutivo da invenção só será compreensível, na sua tendência, se se recorre ao conteúdo relativo à propriedade que encerra o conceito de invento na Idade Moderna. A objeção - já desenvolvida na Antiguidade contra a propriedade privada - de que a natureza teria posto tudo //15 à disposição de todos não respeita ao que é o invento; daí que a autoria se tenha convertido na plasmação, pura e inexpugnável, do que é a propriedade. Não obstante, a instituição jurídica da proteção dos direitos de propriedade do inventor sobre a sua obra, que só experimentará o seu pleno desenvolvimento por volta de finais do século XVIII, não goza, em absoluto, da obviedade que, entretanto, foi adquirida

${ }^{5}$ Ibid.: "Uma história crítica da tecnologia mostraria quão pouco uma qualquer invenção do século XVIII pertence a um só indivíduo." A restrição ao século XVIII não é, neste contexto, insignificante, pois permite que haja, em princípio, uma outra conceção teórica para os primórdios da técnica. 


\section{Textos traduzidos}

O direito de propriedade sobre as invenções desenrola-se no curso da discussão sobre a limitação do direito do príncipe a conceder privilégios, diferenciando-se o outorgamento de um monopólio comercial - algo prototípico do absolutismo - sobre uma mercadoria acessível, no fundo, a quem quer que seja, da patente como direito adquirido do primeiro inventor real de um novo produto. Desse modo se protege, não se fundamenta, o âmbito natural do seu direito. A conceção do invento como uma propriedade protegida, referida não a uma coisa, mas à ideia de uma coisa, tem uma série de pressupostos de ordem intelectual e histórica em que se tornam questionáveis as conceções tradicionais sobre a realidade e o ser humano. Aqui aparece pela primeira vez no horizonte da possibilidade que possa haver propriamente objetos que antes não estavam na natureza e para os quais já não valia a definição aristotélica das capacidades humanas como uma imitação da natureza. Basta recordar que a expressão "ideia”, usada também comumente por nós para designar uma ocorrência humana, no seu primitivo significado platónico só valia para os modelos primigénios de tudo aquilo que se encontra na natureza, que é o conjunto de todas as reproduções. É impossível que a ideia possa aqui designar um plano conceptual independente do dado. //16 Se intentamos captar a viragem histórica que se realizou na história do conceito de "ideia" deparamos, como figura chave desta viragem, em meados do século XV, nos Diálogos de Nicolau de Cusa, com a figura do laico. Essa criação foi concebida pelo filósofo para enfrentar o tipo de intelectual escolástico e a sua imagem tradicional sobre a natureza e o homem. Trata-se do homem da experiência quotidiana, que sabe medir, contar e pesar, um artesão que produz utensílios de madeira para uso caseiro. E precisamente nesses utensílios demonstra ele, no diálogo "sobre a mente humana", que a sua produção não pode ser explicada mediante a fórmula da imitação da natureza. "As formas essenciais de colheres, tigelas e jarras foram realizadas exclusivamente por uma arte humana». ${ }^{6}$ Numa época, pois, em que a teoria das artes ainda estava dominada pelo princípio aristotélico da imitação, a atividade pouco apreciada do artesão encontra uma interpretação na qual não só não se esquiva, mas precisamente se busca, a comparação da atividade do homem com as obras da criação divina.

Porém, ao mesmo tempo, essa tendência para apresentar o laico como figura antagónica ao tipo escolástico torna um problema o valor testemunhal da prova. Aqui não tem lugar primordialmente uma valoração do ser humano, para a qual se teriam tido provavelmente que buscar as formas de atividade mais valorizadas naquela época, mas o artesão é introduzido, contra a soberba do intelectual, como figura representativa da modéstia e, ao mesmo tempo, desvalorizada na //17 tradição das artes liberales. O que o laico faz e o que é, parece necessitar de uma justificação. O que se considera um novo valor, o do seu trabalho de invenção, serve para colocar em destaque uma atitude, uma forma de vida menosprezada no sistema social medieval, e não para uma nova fundamentação da origem das criações técnicas enquanto tais. Com ele se torna compreensível que esta certificação que Nicolau de Cusa fez no século XV permanecesse isolada, e de momento, inefetiva. Até às aplicações que o exemplo do laico de Nicolau de Cusa encontra na essência do espírito humano permanecem confinadas ao âmbito epistemológico, não indo, no fundo, além do que a própria Escolástica da última época medieval tinha dito sobre o surgimento dos conceitos. O conceito, tal como foi entendido pela escola nominalista, já não reproduz a

${ }^{6}$ Idiota de mente, c. 2. 
coisa, somente a capta, integrando-a numa rede de estruturas concebidas pelo próprio homem. No fundo, os conceitos são, para o nominalismo, invenções, e o seu sistema um dispositivo da mente humana para compreendê-las face ao inabarcável do concreto. Mas essa invenção mental não é nada majestosa, é uma solução de emergência, uma função da impotência e indigência do intelecto humano, que já não é capaz de reproduzir a razão que sustenta a natureza. Nicolau de Cusa deu a esse facto, na sua figura do laico, um signo diferente: o que era indigência converteu-se numa distinção. A história do espírito da técnica girou, em essência, até hoje, em torno de signos e valorações //18 onde parece que não se decidiu ainda que valor corresponde definitivamente à técnica.

Um segundo exemplo em que queria mostrar a equivocidade do transfundo intelectual e histórico da tecnificação incipiente é a importância, para este processo, da representação do que é uma lei natural. Na história inicial da mecânica da Idade Moderna e do novo interesse pelas chamadas máquinas simples desempenha um papel relevante o tratado falsamente atribuído a Aristóteles sobre a Mecânica. Os mecanismos simples, nos quais uma pequena força move um grande peso, são apresentados sob o ponto de vista da produção de efeitos extraordinários obtidos ludibriando a natureza. Este pensamento estava já oculto na origem grega da expressão "mecânica". No século XVII esta mecânica, entendida como estratagema ou truque, entra em colisão com a representação da lei natural, que, prioritariamente, encerrava uma metafórica de claro cunho político. Este conteúdo metafórico desapareceu na nossa conceção das leis naturais, que só continuam a significar algo como os conceitos genéricos das mudanças da natureza ou as delimitações que nós atribuímos, por experiência, às nossas expectativas teóricas e práticas. A representação do cosmos, desenvolvida na época helenística como um Estado universal, tinha entendido a lei natural por analogia com a lei política, imposta a todos os membros do mundo como um código legislativo ao mesmo tempo físico e moral e que exige a todos eles obediência. Mas esta analogia deixa aberta a possibilidade de que a lei possa ser transgredida, de que se possa, //19 com manha, contrariá-la e retirar, com enganos, um proveito vedado ao comum dos seres. A Mecânica era como uma síntese de tais truques. É verdade que, para o verdadeiro Aristóteles, este pensamento teria sido ainda impossível, pois, para ele, tanto a técnica como a arte eram, enquanto imitações, dependentes precisamente da natureza e do inerente a ela; além disso, para o homem não existia, em absoluto, a necessidade de criar ele mesmo algo que, de todo o modo, a natureza, com o seu finalismo, já lhe proporcionava.

Para o cristianismo isto já não era tão óbvio. A natureza já não era o paraíso onde o ser humano tinha podido, noutro tempo, viver sem preocupações e sem enganos. E aí estava - como um efetivo inalienável da história das origens do cristianismo e seu companheiro constante - o milagre, no qual se comprovava como o próprio Deus manipulava o vinculante da sua criação, como o extraordinário se elevava, como algo reservado a Ele, acima da ordem da natureza e podendo ocorrer nela a qualquer momento. Não é por acaso que o cristianismo primitivo apareceu, aos olhos do mundo circundante, como uma conjura contra as leis da natureza; nos autores cristãos encontram-se múltiplas pistas de uma atitude de defesa contra essa censura. O facto de a magia não só poder continuar a subsistir na era cristã, mas, nalgumas ocasiões, expandir-se sem ser perturbada em absoluto e como algo óbvio, foi propiciado, sem dúvida, pela circunstância da ordem natural aparecer como algo, por princípio, quebrável. 


\section{Textos traduzidos}

$\mathrm{Na}$ época da forma de estado absolutista, que pressupunha uma arbitrariedade do legislador convertida quase em algo natural, a metáfora da lei natural pôde tornar mais plausível o pensamento de enfraquecer e //20 menosprezar a ordem graças à própria habilidade, como uma autoafirmação face a qualquer classe de lei. Não surpreende, pois, que o escrito pseudoaristotélico sobre problemas mecânicos topasse com uma afinidade de interesses pelo raro, o estranho e o prodigioso. Tanto a natureza como o Estado tinham-se convertido na encarnação de uma ordem estabelecida mediante decretos soberanos, onde o interesse e a felicidade do homem não apareciam como algo previsto para ele; o único que lhe dava esperanças era o prodigioso, ou a habilidade de autoafirmar-se. O escrito acerca da mecânica, sancionado com o nome de Aristóteles, parecia abrir a porta à produção humana de coisas prodigiosas com base na destreza. O tratado define o prodigioso, por um lado, como aquilo que acontece, certamente, segundo a natureza, mas cujas causas não podem ser explicadas, e, por outro, como algo que tem lugar, graças à indústria humana e a favor do homem, contra a própria natureza. E para não deixar que isto pareça mera soberba, o interesse que o homem possa ter para atuar contra a natureza é fundamentado no fato da própria natureza atentar, de múltiplas maneiras, precisamente pela regularidade do seu curso, contra as necessidades do homem, as quais são, por seu turno, muito variáveis. ${ }^{7}$ A Mecânica de Guidobaldo del Monte, aparecida em //21 1577, ainda permanece determinada pela suposta dupla tradição aristotélica, segundo a qual a técnica pode ser tanto uma imitação da natureza como uma transgressão das suas leis, estando permitido ao ser humano servir-se desses dois caminhos para aligeirar a sua "carga" (no sentido literal). Ambas as vias levariam a um único fim: que o homem tenha plenos poderes para dominar a natureza e dispor dela.

O conceito de lei natural, "falso" na perspetiva da história da ciência, exerce uma função historicamente importante: impulsiona o fator da autoafirmação como motivador do interesse pela técnica frente a uma natureza que tornaria o homem inseguro. As máquinas lúdicas e os aparelhos mágicos do barroco dão-nos ainda o reflexo do truque mecânico. ${ }^{8} \mathrm{O}$ que pôde ser importante para o desenvolvimento //22 da consciência da necessidade de uma relação técnica com o mundo evidenciava-se um beco sem saída para a história da técnica no sentido mais estrito. Em nenhum outro lugar se manifesta de uma forma tão plástica o final do mundo barroco de curiosidades técnicas como no relatório que produziu

\footnotetext{
7 Quaestiones mechanicae, edição "Akademie" das obras de Aristóteles, ed. I. Bekker, 847a 11-18. Para o esclarecimento da distância entre "natureza" e "técnica" é instrutiva a passagem que cita o poeta Antifonte (a 20): "dominamos através das técnicas aquilo que nos domina a partir da Natureza”. Cfr. a classificação da Mecânica transmitida por Proclo, no seu comentário a Euclides (ed. de Friedlein, 41, 5ss.), onde surge em primeiro lugar a "organopoike", a construção da máquinas de guerra, seguida em segundo lugar pela "thaumatopoike", a produção do prodigioso, em forma de autómatos e outras figuras que se movem por si próprias.

${ }^{8}$ Nos gabinetes de curiosidades do século XVI que tinham exposto quase na exclusividade rariora naturalia, introduziram-se pouco a pouco artificia rariora. O célebre "museu" de Athanasius Kircher (1601-1680), em Roma, terá sido um imponente exemplo de exposição tanto de prodígios produzidos pela Natureza como também das potencialidades naturais exploradas pelo homem "contra a própria Natureza". O plano para um "novo tipo de exposição", esboçado por Leibniz em 1675, evidencia impressionantemente a homogeneidade dos interesses em raridades naturais e técnicas (“Drôle de pensée touchant une nouvelle sorte de représentations ...", ed. E. Gerland, em Abhandlungen zur Geschichte der mathematischen Wissenschaften, XXI, Leipzig 1906). No catálogo dos objetos de exposição constam animais raros, ilusões óticas, adivinhadores meteorológicos, calculadoras, novos jogos de tabuleiro, autómatos de músicas, fogos de artifício e máquinas voadoras. A utilidade e a finalidade programática do museu foram desenhados assim: "Abriria os olhos ao público, impulsionaria novos inventos, ofereceria belas vistas e instruiria a gente através de um número infinito de novidades úteis e cultas. Quem tivesse uma invenção ou uma proposta engenhosa, teria a possibilidade de a tornar pública e de tirar lucro dela. Criar-se-ia um verdadeiro mercado de inventos. Quem se preocupasse com a sua formação e quem fosse curioso, visitaria o museu para falar disto nas conversações, e mesmo as senhoras cultas gostariam de ser vistas ali, e mais do que uma vez." Uma marginália a este plano, por ventura já respondendo a objeções internas ou externas, é de maior significância: "Poderá algo ter maior legitimação do que usar o extraordinário para servir a ordem?" O inventor Leibniz, ele próprio, costumava frequentemente realçar, através de formulações paradoxais dos seus projetos, o lado "negativo" do prodigioso, como demonstra, a título de exemplo, uma anotação datada de 24 de dezembro de 1678: "Navigar adverso flumine ipsa fluminis vi." - para não falar da produção do motus perpetuus (Cfr. E. Bodemann. Die Leibniz-Handschriften der Königlich öffentlichen Bibliothek zu Hannover, Hannover 1895, 331-333).
} 
Goethe, nos seus Annalen, sobre uma visita que ele próprio fez, em 1805, ao professor Beireis de Helmstedt e ao seu famoso gabinete de curiosidades. Aquelas coisas prodigiosas tinham-se transformado, no início do século XIX, em simples olarias. Goethe escreve a esse respeito: «Não poucos dos seus haveres anteriores, que ainda se tinham até então mantido vivos pelo nome e a fama adquiridos, encontravam-se em condições lastimáveis; os autómatos vaucansonianos encontramo-los completamente paralisados. Num velho pavilhão estava sentado o flautista, com a sua modesta vestimenta, mas já não tocava... O pato, sem penas, estava ali como um esqueleto, continuava a comer, animado, a sua aveia, mas já não digeria: Beireis, contudo, não se mostrava de modo algum confuso, mas falava destas coisas antiquadas e semidestruídas com um regozijo tal e uma expressão de tanta importância //23 como se desde aquela sua época a mecânica superior não tivesse produzido nada de novo mais relevante». Não há dúvida de que agradava a Goethe um pouco essa caducidade quase orgânica dos mecanismos.

Seria erróneo crer que alguma via, direta ou indireta, tinha podido conduzir do famoso pato de Vaucanson que Goethe contemplou no gabinete de Beireis num estado já agónico aos modelos autoimpelidos da cibernética moderna, como, por exemplo, a tartaruga, hoje já famosa, de Shannon. O frutífero do conceito de lei natural não residia nos seus supostos prodígios, como demonstração contra o carácter vinculante da natureza. O primeiro a vê-lo foi Galileu. A sua Física representava já, no fundo, o final da magia naturalis, a opinião definitiva de que a natureza não se deixa enganar e que representa um sólido equilíbrio, onde todo o ganho em força significa uma diminuição de tempo. A introdução da matemática na mecânica supôs o final da metafórica política que o conceito de lei natural encerrava, e das ilusões dimanantes do mesmo.

Quando Galilei escreveu, em 1593, o seu tratado inicial Intorno aggli effetti degl instrumenti meccanici, estava totalmente familiarizado com o antigo tratado citado sobre os problemas da mecânica, em torno dos quais ainda dava lições na Universidade de Pádua em 1597-1598. Mas ele mesmo partiu, resolutamente, da posição contrária: os efeitos da técnica não podem conseguir-se contra as leis da natureza, mas unicamente de acordo com as leis da natureza. Galilei invoca a experiência, a partir da qual teria chegado à firme convicção de que a natureza não pode ser nem superada nem enganada pela arte. ${ }^{9}$ //24 Contudo, isto não significa um retorno à teoria imitativa da técnica, pois atuar sob leis é algo totalmente distinto de atuar segundo modelos prefigurados.

A sua formulação mais combativa, ainda que não seja o seu melhor argumento, encontrá-la-á este mesmo pensamento um quarto de século depois, com Francis Bacon: não se poderá dominar a natureza senão submetendo-a. Isto representaria uma fórmula de compromisso entre as duas tendências iniciais do conceito de lei da natureza, uma fórmula que iria parecer plausível durante muito tempo, talvez porque, mais que fazer reconhecer, esconde a problemática inerente ao conceito.

Galilei tinha reconhecido, de modo sereno e pleno, a inviolabilidade da lei da natureza, diferentemente da lei política. As máquinas e os dispositivos com que se deparou no Arsenal de Veneza constituíam, a seus olhos, modelos simplificados, não superações, da

\footnotetext{
9 Intorno aggli effetti degl 'instrumenti meccanici (Opere, ed naz. VIII, 572): "E perchè io, già gran tempo fa, mi era formato un concetto, e per molte e molte esperienze confermatolo, che la natura non potesse esser superata e defraudata dall'arte, nel veder si fatta maraviglia restai ammirato e confuso: e non potendo quietar la mente nè deviarla dal meditare sopra questo caso, ho fatto un cumulo di vari pensieri...”
} 


\section{Textos traduzidos}

natureza. A lei da natureza já não lhe aparecia como um decreto da vontade divina imposto à natureza, mas como determinação das dependências ínsitas nas coisas, dada necessariamente com a natureza das mesmas. Esta seria a definição geral da lei que Montesquieu colocará no princípio da sua obra, de 1748, O espírito das leis, onde tenta, ao invés, derivar a lei política partindo da definição das leis da natureza desenvolvida por Newton. ${ }^{10}$ //25 Mas o conceito consequente de lei não será alcançado até ao século XVIII, cuja ilustração cimentará nele, sobretudo, a sua crítica dos milagres. ${ }^{11}$

Galilei ainda considerava a lei da natureza como um decreto divino, mas o seu Deus não era um Deus que pudesse contradizer-se a si próprio na sua obra e que quisesse tornar com isso impossível o conhecimento da natureza. Numa perspetiva teórica, o lugar atribuído a este conceito de lei natural era o de indicar que o conhecimento é o único pressuposto para a solução dos problemas, oferecendo a própria natureza as soluções, mas não mediante uma mera imitação. A compreensão da lei da natureza não só tornava possível a técnica, como o apelo à lei da natureza legitimava as suas prestações. A representação da lei da natureza tinha sido concebida, desde a sua origem, como uma barreira à atuação demiúrgica do homem; agora convertia-se na sua habilitadora, ao revelar-se a lei da natureza como a quintessência daqueles conhecimentos que permitiam ao ser humano levar a cabo inclusive e precisamente, o que a própria natureza na sua existência dada não executava nem propiciava. Ao não serem vistas as leis da natureza de maneira prioritária como descrições dos processos na sua //26 regularidade, mas como normas que estavam por cima dos processos, o conceito daquelas induziu a pensar que era possível outra forma de realidade, ainda que esta fosse, certamente, em termos estruturais, do mesmo género. Só com a consideração de todas as formas da natureza segundo a sua génese iria conseguir esta conceção a sua plena confirmação, quando o visível se revelava como o resultado momentâneo de uma série de processos determinados por leis.

Na estreita vinculação das origens da técnica da Idade Moderna com o pensamento da lei natural se revela uma necessidade de justificação, que recebe, uma e outra vez, novos impulsos da antiga antítese entre o natural e o artificial. O sucesso ou fracasso na tarefa de legitimação da técnica constitui uma alternativa decisiva para a articulação da consciência moderna. Ninguém quererá nem poderá afirmar que os séculos da acelerada e crescente tecnificação do mundo que nos circunda tenham bastado para estabilizar uma relação, por assim dizer, normal e óbvia do homem moderno com o âmbito tecnológico. O próprio progresso técnico parece impedi-lo, ao encobrir o equilíbrio alcançado em cada caso entre os meios técnicos e os modos de comportamento humano, submetendo a uma sobre-exigência, no lapso de cada geração, as formas de reação orgânica e as capacidades incorporadas. Esta dificuldade subjacente ao próprio assunto em questão busca determinados modos de expressão do mal-estar, oscilando entre o otimismo e o pessimismo extremos, a idolatria e a demonização. Em tudo isso a nossa tradição europeia coloca à disposição, de forma preponderante, uma série de categorias que implicam uma valorização negativa, por ser ela mesma uma //27 tradição onde se identificou a natureza e a realidade. Mas é justamente a função da tradição no mal-estar moderno que converte em duvidosos e equívocos para uma

${ }^{10}$ L'esprit des lois I, 1: "Les lois dans la signification la plus étendue sont les rapports nécessaires qui dérivent de la nature des choses." 11 Voltaire, Artigo "Miracle", em Dictionnaire Philosophique, ed. Naves, p. 314 e ss.: "un miracle est une contradiction dans les termes ...". Em Deus, lei e graça são uma e a mesma: "ses faveurs sont dans les lois mêmes ..."; cfr. Artigo "Grace", op. cit., p. 227: o homem não pode reclamar para si uma exceção perante as leis, se Deus não confere esta exceção nem sequer aos astros. 
história do espírito da técnica os termos da argumentação: o mal-estar que busca a sua expressão numa formulação tradicional não precisa ter tomado a sua origem da própria tradição. Mas por outro lado, pode, ou poderia ser assim, e o historiador da técnica incorre no perigo de confundir - ou, pelo menos, não diferenciar claramente - entre uma argumentação defensiva e uma motivação conducente ao impasse. Em qualquer caso, a tradição filosófica coloca à disposição do mal-estar pela tecnificação os meios linguísticos mais plausíveis; e, em contrapartida, o intento de fazer da consciência uma pátria para técnica, de criar uma confiança na técnica ou de impor o postulado de dispor criticamente da técnica carece de meios categoriais que nos sejam familiares e que estejam sancionados no património cultural. A esfera da tecnicidade sofre de carências de linguagem, de defeitos categoriais. Isto foi expresso também dizendo que os nossos ideais e conteúdos culturais não oferecem nenhuma ajuda para a obtenção de uma postura moderada em relação à técnica, coisa que pode palpar-se precisamente entre aqueles que procuram reconciliar-se com o espírito da técnica partindo de uma perspetiva cristã e invocando o mandamento bíblico da subordinação da Terra. Mas o caso é que este mandamento é contíguo a essa negra condenação que condiciona a submissão da Terra ao trabalho e ao suor, colocando com isso tudo aquilo sob suspeita que acaba por interpolar entre o ser humano e a Terra todo um instrumental de dominação que, pelos seus //28 propósitos e pelos seus efeitos progressivos, garantiria a submissão da Terra com o mínimo de trabalho e suor.

Se é certo que hoje vivemos num mundo talhado pela ciência e pela técnica, mas com um tipo de consciência em grande medida pré-científica e pré-tecnológica, isso teria que ver não pouco com o facto de ainda não nos temos desembaraçado da antítese entre natureza e técnica. O conceito de natureza foi sendo acompanhado sempre na nossa tradição por um fator de sanção da realidade dada de antemão ao ser humano. O natural foi entendido como correspondendo à vontade da natureza. Mesmo um grande apreciador da nossa tradição humanística tão pouco poderá ignorar que este conceito de natureza mergulha as suas raízes precisamente nela. Sempre continua a haver aí algo que se corresponde com aquele antigo pensamento fundamental e que simpatiza com ele, um pensamento que fez com que a Ésquilo e a Heródoto lhes parecesse um sacrilégio que Xerxes atravessasse o Helesponto. ${ }^{12}$ O primeiro guia de viagens pela Grécia, elaborado no século II por Pausânias, contém um catálogo inteiro de mudanças importantes da paisagem produzidas pela ação humana, qualificando-o de atos de violência perpetrados contra os deuses. ${ }^{13}$ Aquilo a que nós chamamos hoje crítica da cultura serviu-se desde a Antiguidade //29 do ideal da inviolata terra, conforme à representação utópica da Idade de Ouro, que se teria visto livre da fadiga e da preocupação precisamente pelo desconhecimento de todo o tipo de destreza técnica. ${ }^{14}$ Se para esta consideração negativa do progresso a agricultura aparecia já como uma rutura da sanção da terra, será a exploração mineira que se converterá de verdade no caso modelar do confronto com essa relíquia míticas.

\footnotetext{
${ }^{12}$ Ésquilo, Os Persas, 746ss.; Heródoto VII, 33-35. Cfr. Aríston de Quios, frag. 13, VII (ed. Wehrli, Schule des Aristoteles VI, 36, 9-11). ${ }^{13}$ Pausânias, Periegesis II 1, 5. A raiz mítica deste postulado da Natureza intacta terá sido de caráter dúbio: os deuses a invejar o poder dos homens (cfr. Burckhardt, Griechische Kulturgeschichte III, 2; Gesammelte Werke VI, 97ss.). Será que ainda se encontram vestígios desta raiz na consciência coletiva hodierna?

${ }^{14}$ Como exemplo típico cfr. a fórmula de Dicearco (frag. 49, Wehrli, op. cit. I, 24): “... necesse est humanae vitae a summa memoria gradatim descendisse ad hanc aetatem ... et summum gradum fuisse naturalem, cum viverent homines ex his rebus, quae inviolata ultro ferret terra...”. Cfr. também outra passagem de Dicearco citada por Porfírio, De abstinencia, IV, 2 (frag. 49, ed. Wehrli), que associa o estádio originário, onde não havia ainda agricultura, com o ócio livre de fadiga e de preocupação.
} 


\section{Textos traduzidos}

Quando por volta de meados do século XVI Georgius Agricola se viu confrontado, no seu De re metallica, com essa argumentação, formulou-a do seguinte modo: «A terra não oculta e também não subtrai aos olhos aquelas coisas que resultam úteis e necessárias para o género humano, mas que as dispensa espontaneamente com maior liberalidade, como uma boa mãe, fazendo com que apareçam diante do olhar e à luz do dia ervas aromáticas, legumes, frutos e frutas silvestres. Em contrapartida as coisas que se têm que retirar escavando empurrou-as para as profundezas e, por isso, não devem ser extraídas (...)».15 Entre os problemas típicos da //30 época destaca-se, com uma importância, tanto teórica como prática, a questão do direito que possa ter o homem sobre o que a terra lhe oculta. Em tudo o que se escondia debaixo da terra e no afastado do firmamento - o extremamente pequeno e o extremamente grande -, a natureza parecia ser cada vez menos uma bondosa protetora dos seus segredos, convertendo-se, antes, num desafio para a curiosidade humana e para o trabalho de apropriar-se finalmente daquilo que até então tinha permanecido oculto. Ficava patente que o que impedia o homem de ultrapassar os seus limites fortuitos e aprender a estar orgulhoso da sua força não era uma natureza que escondia os seus tesouros, mas o tranquilizador pensamento do finalismo da natureza. Já em 1719 a Academia de Bordéus pôde estabelecer num concurso a tarefa de elaborar uma história da terra e de todas as transformações nela produzidas, tendo em conta não apenas os terremotos e as catástrofes das inundaç̃̃es, mas também o realizado pela mão do homem. A comprovação do poder do ser humano sobre a natureza ficou traduzido em formulações filosóficas que até então estiveram totalmente fora do expressável. Campanella escreve: «Para imitar a Deus o homem anseia poder tudo, saber tudo e querer tudo, não deixando que nada lhe resista. No cume da sua inteligência, mostra-se facilmente inclinado a acolher qualquer teoria das artes mecânicas, para não permanecer ignorante em matéria alguma.»16 O Santo Ofício condenava expressamente, mediante o decreto de 23 novembro de 1679, //31 a afirmação de que Deus tinha deixado ao homem, para que a use, a sua omnipotência, de um modo similar a alguém que deixa que outro utilize a sua casa ou lhe empresta um livro. ${ }^{17}$

$\mathrm{O}$ conflito pelo direito da natureza a manter-se reservada ainda não foi superado, e talvez não tenha chegado ainda ao seu ponto limite. E agudizar-se-á, se for certo que a biologia atual se encontra apenas nos primórdios de um desenvolvimento cujas consequências poderiam ser a crescente disponibilidade até mesmo das estruturas orgânicas, para ir ao núcleo da substância genética, de tal maneira que a tecnificação do orgânico mais não teria que começado. No entanto, é certo que o conceito de natureza da nossa tradição está orientado, sobretudo, para os fenómenos e as propriedades da esfera orgânica. Não deve ignorar-se que a preocupação ante esta fase de tecnificação que talvez entre agora na sua fase decisiva tem também as suas razões objetivas - mas, se for esse o caso, ela apontará mais do que para a questão de se com isso se viola um suposto direito da natureza a que o homem se abstenha de intervir até ao fundo, para esta outra questão: quem disporá deste novo poder do homem e como este poderá ser circunscrito em prol da humanidade. Só recentemente a

\footnotetext{
15 O incêndio da camada de carvão em Zwickau no ano de 1505 que na altura chamou grande atenção e tornou aguda a questão da legitimidade da apropriação do escondido na terra. A atenção a este caso parece estar ainda percetível, 23 anos após o sucedido, na obra Bermanus sive de re metallica de Agricola.

${ }_{16}$ Realis Philosophiae Epilogisticae partes quattuor. 1623, 357: "Ut autem Deum imitetur, omnia posse cupit, omnia scire, et omnia vellet, nihilque sibi adversari. Unde optimus serenitate ingenii, omnem artium mechanicarum facile addicit theoriam, ut nulla in re sit indoctus."

17 Denzinger-Umberg, Enchiridion Symbolorum, ed. 23, Freiburg 1937, nº 1217: "Deus donat nobis omipotentiam suam, ut ea utamur, sicut aliquis donat alteri villam vel librum."
} 
biologia foi perdendo o seu carácter de ciência descritiva e classificatória, aproximando-se cada vez mais da química e da física. Não obstante, o facto da física e da química serem ciências da natureza não impediu até hoje que //32 o uso linguístico continua a entender como o "natural" aquilo que tem devir e consistência sem a ciência nem a técnica. As fundamentais representações orgânicas desempenharam, desde o romantismo, como metáforas usadas na linguagem da teoria do Estado e da teoria política, uma função dirigida contra o pensamento racional e construtivo, adquirindo, a partir desta esfera, um reforço da antítese entre o naturalmente existente e a obra humana. Uma história do espírito da técnica terá de trazer, de forma crítica, à consciência, precisamente em relação a tais determinações linguísticas, quais são os pressupostos que nos rodeiam e o que poderia impedir-nos de ter uma visão da própria coisa. Não só na própria técnica, mas também na atitude a respeito dela resultará necessário o mais elevado grau de consciencialização de todos os condicionamentos da questão. Lichtenberg assinalou numa ocasião: «Fazemos a todo momento algo que não sabemos, até que, finalmente o ser humano fará tudo sem saber, convertendo-se, no sentido próprio da expressão, num animal pensante (...)».18

Chegamos assim ao terceiro dos exemplos que queria aduzir para ilustrar as dificuldades de uma história do espírito da técnica. O interesse histórico pela técnica compete sempre com um aspeto distinto, que eu chamaria antropológico. De uma perspetiva biológica, o ser humano entrou no cenário do mundo como um ser deficientemente equipado e adaptado e teve que desenvolver, desde o princípio, para a //33 sua autoafirmação e para assegurar a satisfação das suas necessidades, uma série de meios auxiliares, baseado em instrumentos e procedimentos técnicos. Mas o instrumental requerido para a sua autoconservação permaneceu estável durante longos períodos e com uma margem de variantes mínima, e parece que o homem não viu a sua situação no mundo, ao longo de extensos períodos da sua história, como uma situação de essencial carência e penúria. A imagem que forjou de si próprio estaria, antes, determinada pelas características próprias de um ser bem-dotado pela natureza, mas que fracassa na distribuição dos bens daquela; daí que o problema da justiça tenha sido formulado, predominantemente, como um problema de medidas idóneas de distribuição. Por conseguinte, a nossa tradição está dominada, em grande medida, pela ideia de que a natureza constitui uma ordem estabelecida por causa do homem e orientada para o homem. É fácil ver como, no marco desta representação, as habilidades e performances técnicas do ser humano só podiam desempenhar uma função complementar, que coadjuva a natureza e executa a sua finalidade. O abandono da confiança naquela estrutura de ordem do kósmos amigo do homem por parte de uma ideia da natureza que cumpre unicamente as leis que lhe são imanentes teve que significar uma viragem sobretudo pragmática na compreensão do mundo e na relação do ser humano com aquele. Daí que a capacidade de transformação técnica e sobretudo de dominação da realidade tinham que adquirir um novo sentido.

Esta mudança brusca do que poderia chamar-se o carácter "humano" do mundo até converter-se este num mundo que parece não ter consideração alguma com o homem ocorre na fase de transição da Idade Média para a Idade Moderna. A Idade Média chegava //34 ao seu fim ao não poder manter-se crível para o homem, dentro do seu sistema espiritual, que a criação era algo providencial para ele. O estádio moderno da história da tecnicidade humana

${ }^{18}$ Lichtenberg, Georg Christoph, Vermischte Schriften. Göttingen 1800/1806, I, 158. 


\section{Textos traduzidos}

pode ser considerado, por isso, não só do ponto de vista do incremento quantitativo das performances e dos recursos de índole técnica. Antes, por detrás do crescimento acelerado do âmbito tecnológico há uma vontade, conscientemente enfrentada com a realidade alienada, de forçar mediante a técnica um novo "carácter humano" da realidade. O ser humano reflete sobre as carências da natureza e sobre a sua própria indigência vendo-as como movens de todo o seu comportamento.

Ninguém expressou de um modo tão claro e com tanta dureza como Nietzsche este pensamento do ser humano abandonado pela providência da natureza e entregue à sua própria responsabilidade. Mas também em nenhum outro como ele se torna assim mesmo palpável a ambiguidade dessa relação - e com isso o perigo da compreensão histórica. Não é que Nietzsche coloque sob a suspeita do ideológico essa relação de fundamentação entre um mundo sem ordem e o poder do próprio homem, mas ele próprio usa essa relação como ideologia, potenciando como programa o que lhe parece uma tendência histórica. Nietzsche não vê no facto de que desapareça e se torne questionável o mundo ordenado e que resultava familiar a grande deceção e angústia do ser humano que o teria forçado, contra a sua vontade, a colocar tanta atenção na sua autoafirmação teórica e prática e a criar na ciência e na técnica o instrumental de dominação sobre a realidade alheia e adversa. //35 Para Nietzsche, a destruição da sossegada confiança no mundo seria, antes, a condição do incremento criativo da valorização do criativo e do autodesenvolvimento do homem. Só agora este se teria libertado do atrofiamento fatal da sua atividade. A ideia de providência e finalismo da natureza seria a «crença mais paralisadora que alguma vez existiu para a mão e para a razão» do homem, que o teria conduzido a uma "absurda confiança na marcha das coisas». Somente a interpretação mecanicista do mundo da incipiente ciência da natureza teria despertado e libertado a vontade demiúrgica do ser humano, entregando-lhe o mundo como material para a sua própria "construção do mundo". Aqui já não se trata da mera autoconservação ou da necessidade de autopreservação do homem, mas do seu autoincremento, disso que Nietzsche chama a «mais elevada evolução do ser humano como a mais elevada evolução do mundo». Para o homem não teria sentido algum continuar a perguntar o que é o mundo, pois no que este possa tornar-se depende dele próprio.

Assim se chega, para Nietzsche, ao ponto culminante da indiferença do conceito tradicional de verdade, que significava uma adequada captação da realidade: «O filósofo não busca a verdade, mas a metamorfose do mundo no homem».

Ora, poderia muito bem pensar-se que esta formulação atingiria exatamente a autocompreensão de um século entregue aos seus triunfos tecnológicos. Mas o próprio Nietzsche negligenciou esta possibilidade de interpretação do seu pensamento fundamental, provavelmente porque entendia a técnica como esta acreditava que devia autoentender-se, //36 a saber, como uma ciência da natureza aplicada e uma forma de obediência às leis naturais, como uma derivação, por conseguinte, daquela ideia de verdade que Nietzsche queria em concreto superar, o último resto do carácter vinculante do mundo. Para ele, tanto o lugar da verdade como o lugar da técnica ficam ocupados pela arte, chamada a representar a veracidade do ser humano "numa natureza mendaz». A técnica ainda não se tinha apresentado, nem tão pouco entendido a si mesma, como uma nova realidade; mais, temia até abandonar aquele pensamento, justificador e familiar, de que todo o técnico é uma imitação do natural. Daí que, para Nietzsche somente a arte podia ostentar o nível 
paradigmático do que é uma nova autoconsciência, e à arte dedica a sua obstinada expressão: «A nossa salvação não está no conhecimento, mas na criação! (...) Se o universo não nos diz respeito queremos ter o direito a desprezá-lo.»19 O carácter suspeito da ideologia converteu-se em certeza quando a instrumentalização da ideia celebra o seu próprio engano. A ideia é produzida para obrigar o homem a não deixar estar o mundo como é, fazendo-se com que ele próprio se torna mais do que alguma vez o foi. Onde isto aparece com maior clareza é no pensamento do eterno retorno do mesmo, que ao último Nietzsche lhe parece o meio idóneo para selecionar o super-homem: «Proponho a grande prova: quem aguenta o pensamento do eterno retorno? Tudo o que seja suscetível de ser aniquilado com a frase "não há nenhuma salvação” deverá extinguir-se (...)».20 O pensamento //37 filosófico constitui aqui, por um lado, um fator de atraso característico face ao desenvolvimento real, ao formular com uma exacerbação sistemática o que a realidade fez para desafiar o homem, por outro, desempenha uma função de reforço, aceleração e acrescentamento excessivo de um processo que há já muitíssimo tempo estava em marcha. O que é em si uma consequência do desenvolvimento histórico quer converter-se de novo em motor do próprio. A ambiguidade existente na autoafirmação e no autocrescimento dos motivos da tecnificação dos tempos modernos deve ser transposta para uma dependência funcional: a destruição do valor de ordem e previsão do mundo a respeito do homem aparece como a primeira característica, ainda não diáfana para si mesma, de uma vasta revolta histórica. A teleologia da natureza é substituída por uma teleologia da história. Mas o diagnóstico histórico nega-se a servir para que o tornem no prelúdio da chegada do super-homem. A situação em que o ser humano entende a realidade como desordem e carência tem de ser tomada a sério como uma situação de angústia e necessidade de autoafirmação. O conjunto da teoria filosófica do Estado da Idade Moderna tinha-se fundamentado nos pressupostos de uma situação assim, como também quase todas as teorias da vida económica humana e, em grande medida, as teorias sobre a própria teoria, isto é, as teorias sobre a necessidade do conhecimento enquanto desempenho que cria a sua própria face a uma realidade que já não se apresenta como ordem. O modo como se responde aqui à questão de prioridade da ideia ou da situação depende de haver ou não uma experiência //38 das situações que seja, por assim dizer, pura e não interpretada. A humanidade reconheceu em todos os tempos a miséria de uma natureza premente e a carência, mas a generalização de tais experiências como uma valorização da totalidade da realidade tem pressupostos adicionais, não dados já juntamente com aquelas experiências.

Gostaria de explicar isto um pouco mais. Quando o jovem Agostinho se desprendeu da gnósis maniqueia - que tinha atribuído o mal do mundo a um princípio primigénio absoluto do mal - teve de encontrar uma nova solução para o problema desse mal no mundo, uma solução que desonerava o seu Deus, como princípio do bem, de toda a responsabilidade pela degradação do mundo. Esta teodiceia, esta justificação de Deus, significava que os males do mundo constituíam um equivalente, exato e justo, da maldade do próprio homem. ${ }^{21}$ Conforme a este modelo conceptual, o ser humano ver-se-ia neutralizado

\footnotetext{
${ }^{19}$ As citações de Nietzsche são de “Der letzte Philosoph” (1872/75), Ed. Musarion, VI, 16, 18, 31, 35, 50, 58.

${ }^{20}$ Esboços e ideias acerca das partes não acabadas do Zaratustra, Edição Musarion XIV, 187.

${ }_{21}$ Após De libero arbitrio (I 1; II 3), onde esta teodiceia é desenvolvida, lemos a seguinte fórmula em Confessiones X 4,5: "bona mea instituta tua sunt et dona tua: mala mea delicta mea sunt et iudicia tua ...”. Esta representação com a sua intenção antignóstica exclui, ao mesmo tempo, uma qualquer demonização de uma esfera material, inclusive a esfera não natural: "Verissimum est, non res ipsas, sed homines qui eis male utuntur esse culpandos." (De libero arbitrio I, 33).
} 


\section{Textos traduzidos}

como ser tecnológico precisamente pela circunstância de ter que atribuir a si próprio a consternação que lhe produz a realidade, que tem de entender como a manifestação de uma justiça universal, e tratar de detê-la com a suas próprias forças parece uma ação tão desesperada quanto vituperável. Sem o homem e a amplitude dos seus pecados o mundo seria, segundo Agostinho, bom e perfeito. Esta é a antítese exata daquela famosa constatação de Kant no $\S 86$ da Crítica do juízo, que diz que «sem o ser humano //39 toda a criação não é mais do que um mero deserto». Se a inclemência do mundo não reveste, para o homem, as características da justiça, mas é algo fáctico e não explorável de um modo racional, o ser humano não se vê apenas provocado, mas inclusive legitimado, a transformar a realidade com que se depara.

O modo como se perceba e interprete a debilidade de ordem que apresenta o mundo e a sua carência fundamental a respeito das necessidades do homem, não é imputável, portanto, simplesmente à constatação de determinadas circunstâncias físicas, económicas e sociais, mas seria uma questão que tem que ver com as antecipações vinculadas às experiências de tudo isso. A suspeita, a inferência do que pode significar a experiência precede o diagnóstico empírico e muda-o.

Isso aparece com especial clareza num motivo da história do espírito da Idade Moderna que, até então, era desconhecido: a ideia da superpopulação, do crescimento do número de seres humanos para além do âmbito espacial e alimentício natural, pensado com algo constante. Já antes dos números da população humana começarem, de facto, a disparar angustiadamente agudiza-se o medo do crescimento da população e converte-se num tema imperioso a discussão dos seus problemas. Na Utopia de Tomás Moro, de 1516, o problema tinha ainda um carácter regional; pondera-se a possibilidade de uma superpopulação daquela ilha utópica, mas apontando de forma simultânea, como válvula de escape, a colonização do continente próximo. Nos Ensaios de Francis Bacon, cuja primeira edição é de 1597, a simetria natural entre bens e necessidades é substituída pela regulação política, //40 no marco da entidade estatal, cujos instrumentos económicos e jurídicos manteriam o crescimento da população em limites que excluiriam todo o perigo de instabilidade política. ${ }^{22}$ A justiça ética da distribuição dos bens é substituída pelo cálculo político. Em 1642 Hobbes inclui nas suas reflexões o pensamento da superpopulação, numa passagem característica da sua obra, como último sentimento de insegurança capaz de abalar a confiança nos efeitos futuros da filosofia moral: no prólogo dedicatório da sua obra Sobre o cidadão afirma que se os filósofos morais tivessem chegado a explicar alguma vez a questão dos motivos da atuação humana já não haveria mais guerras, com exceção daquelas que teriam de levar-se a cabo, no caso de crescer a população, para buscar um espaço vital ( «nisi de loco, crescente scilicet hominum multitudine»). Uma das controvérsias dos eruditos, em cujo marco costumavam desenvolver-se tais problemas, era a discussão sobre a relação entre o número da população no mundo antigo e no moderno. Montesquieu acreditava na diminuição da população total desde os primórdios da Antiguidade. ${ }^{23}$ A fundação da estatística por parte de William Petty ocorreu no contexto desta questão controversa. ${ }^{24} \mathrm{~A}$ controvérsia alcança, por volta de meados do século XVIII, o seu ponto culminante com os

\footnotetext{
${ }^{22}$ Essays XV, "Of seditions and troubles": "Generally, it is to be foreseen that the population of a kingdom (especially if it be not mown down by wars) do not exceed the stock of the kingdom which should maintain them."

${ }^{23}$ De l'esprit des lois, XXIII, 19.

${ }^{24}$ Essay concerning the multiplication of mankind, 1686. A sua Political Arithmetic foi publicada postumamente, em 1691
} 
tratados sobre esta temática //41 publicados por Hume e Wallace. ${ }^{25} \mathrm{O}$ ceticismo de Hume, profusamente documentado, perante a hipótese de uma maior quantidade de população da Antiguidade foi um argumento importante a favor da teoria da ameaça da sobrepopulação. Na Alemanha, o filósofo ilustrado Hermann Samuel Reimarus acrescentava um argumento inesperado a favor da lei do crescimento da população mundial: só admitindo este pressuposto se poderia demonstrar matematicamente que o género humano começou com um único par de seres humanos. ${ }^{26}$ Mas o que, deste modo, podia resultar consolador para //42 o fortalecimento da religião natural tinha, contudo, como efeito colateral que se vislumbra para o futuro uma lei certamente angustiante: «O aumento do mesmo [do género humano] baseia-se na sua natureza e estende-se à totalidade; a diminuição neste o naquele lugar é casual (...)». Este pensamento do carácter autónomo da lei do incremento da população encontrava, no Essai on the Principle of Population, de Malthus, em 1798, a sua exposição mais rica em consequências para o século XIX. O tratado sobre a lei do aumento da população tornou plausível, como nenhuma outra obra, o processo de tecnificação, na forma de industrialização, enquanto autoafirmação do ser humano. Inclusive a invenção do fertilizante artificial - até hoje uma moléstia contra o natural - encontrava aqui o seu apoio. A carência constitutiva do mundo tinha sido elevada, mais além da suspeita e independentemente da questão sobre as circunstâncias fácticas do momento, ao estatuto de lei natural. Mas enquanto a intenção de Malthus e seus seguidores era exercer um influxo refreador sobre o próprio desenvolvimento da população e superar com o duro regulativo da necessidade a velha ideia do direito da humanidade inteira aos meios de subsistência, o efeito que, de facto, teve essa lei de população foi o desenvolvimento do outro lado do problema: o incremento das possibilidades de subsistência. O progresso técnico demonstrou que a margem de subsistência não era uma constante natural. Para isso contribuiu, antes de mais, a repercussão //43 da lei do aumento da população sobre Darwin: nele, a pressão excessiva e a luta pela existência no seio de uma população biológica conduz a uma evolução do equipamento orgânico do ser vivo, sendo este o modelo em que o progresso técnico encontrou um novo tipo de legitimação natural.

Num apontamento no seu diário, de 1844, Grillparzer formulava de forma conclusiva a conexão entre superpopulação e progresso teórico e técnico: «A característica da nova época é o espírito de investigação. Em parte as ciências avançadas da natureza, em parte a necessidade material, incrementada pela sobrepopulação, empurram-nos irremissivelmente para a análise, para que mediante o conhecimento dos motivos e dos seus

\footnotetext{
25 Hume, David. Essays, Moral, Political, and Literary. Part II, 1752. XI: "Of the Populousness of Ancient Nations. - Dr. Wallace, A Dissertation on the Numbers of Mankind in ancient and modern times: in which the superior Populousness of Antiquity is maintained." 1753. Hume classifica esta questão como "the most curious and important of all questions of erudition" (The Philosophical Works, eds. Green, Grose, Londres 1882, III, 58). O interesse da teologia na asseguração tranquilizadora da correspondência teleológica entre natureza e humanidade anuncia-se na Alemanha no tratado de J.-P. Süßmilch, Über die göttliche Ordnung in den Veränderungen des menschlichen Geschlechts, Berlim 1742.

${ }^{26}$ Reimarus, H. S., Abhandlungen von den vornehmlichen Wahrheiten der natürlichen Religion. Hamburgo 1754 (citado segundo a $6^{\text {a }}$ ed. de 1791), I, 13: "E esta observação conduzir-nos-á necessariamente ao ponto onde temos de reconduzir o género humano em última instância ao número absolutamente mínimo e à sua origem e começo primordial. Pois não é possível que o género humano seja eterno, porque, neste caso, teria que existir, desde tempos infindáveis, pelo menos um número igual de homens ao de agora ...”. Reimarus relata a controvérsia entre Hume e Wallace, encontrando o seu próprio interesse em plena sintonia com o do cético Hume: "Ele argumenta a favor da maior quantidade nos tempos recentes, e torna suspeitas e ridículos muitos dos testemunhos dos antigos historiadores sobre o elevadíssimo número de pessoas nos tempos de então." Mas também Wallace é elogiado pela sua erudição e as suas observações políticas: "Talvez se alcance melhor a verdade quando se compara os dois autores, ambos preocupados em povoar o seu respetivo mundo."
} 


\section{Textos traduzidos}

componentes possamos continuar a progredir, aqui, para novas descobertas, ali, para novos inventos e outros meios de satisfazer a população». ${ }^{27}$

O significado do exemplo da lei da população em relação com os problemas de uma história do espírito da técnica poderia reduzir-se à questão se o pensamento da formulação em leis do risco do crescimento da população deu impulsos e pressupostos à aceleração do processo de tecnificação, //44 ou se foi o próprio facto da pressão da população que se impôs a si mesmo uma regulação técnico-industrial. Esta questão não poderá ser respondida de forma global, tendo que ser abordada, no plano metodológico, de um modo muito diferenciado. Voltando ao exemplo da teoria do fertilizante artificial, cujos fundamentos foram dados por Justus Liebig em 1840 com a sua química agrícola, podemos assinalar que a aplicação do nível teórico alcançado pela química precisamente a esse problema só se torna compreensível pela preocupação de se adiantar ao crescimento da população.

Queria agora, com a ajuda do que procurei ilustrar mediante os meus três exemplos, retirar uma conclusão. As posições ideológicas fundamentais do enfoque e da metodologia de índole histórica - que hoje em dia podem associar-se em grande parte com determinados sistemas políticos e de mundividência - revelam-se como alternativas metodológicas que se têm de decidir, não mediante um fundamentalismo dogmático, mas considerando o próprio material histórico caso por caso. O assunto histórico que há que considerar-se não permite uma clara coordenação entre fatores intelectuais e circunstâncias materiais, conforme ao esquema, por exemplo, de infraestrutura e superestrutura, motivações e consequências, projeto e realização. O intento de abordar uma 'história do espírito da técnica' coloca em relevo isto com uma nitidez muito maior que a série de tarefas colocadas na "história da técnica" e que fazem referência ao contexto de aparecimento dos próprios fenómenos técnicos ou analisam os efeitos das realizações tecnológicas sobre as realidades económicas, sociais, políticas, militares //45 e estéticas. Aqui o historiador continua a estar mais próximo do modelo cronístico de historiografia, poupando nos escrúpulos e nas dificuldades de ordem metodológica em relação à possibilidade da sua tarefa. O pluralismo de modelos com os quais trabalhar uma história do espírito da técnica produziria, à primeira vista, uma impressão dececionante, ao apresentar o aspeto de um ceticismo histórico. Mas a exigência de manter abertas as vias de interpretação das conexões existentes entre a história do espírito da técnica e a história da técnica, e de não se decidir de antemão por um determinado modelo de correspondências, deve precisamente impedir que no enfoque histórico fiquem alojados determinações ideológicas. Talvez haja questões que não possam decidir-se, mas até mesmo esta forma de ver as coisas seria preferível a uma constatação dogmática que ou parte de uma escala de valores, petrificada, segundo a qual a técnica não pode ser nunca outra coisa senão um fenómeno secundário e dependente de um conjunto de decisões fundamentais ideais, ou fica assente no dogma de que a maior proximidade dos fenómenos técnicos a respeito das estruturas materiais, sociais e económicas remete os documentos da história do espírito que possam obter-se à simples função de uma superestrutura

\footnotetext{
${ }^{27}$ Sämtliche Werke, ed. Frank, Pörnbacher, III, 1141. Hoje, o ponto de vista parece ser o oposto: o progresso tecnológico exerce aquela 'pressão' que impulsiona o desenvolvimento da população nos países tecnologicamente mais desenvolvidos, e justamente como mecanismo preventivo contra a diminuição da necessidade de trabalhar. Dennis Gabor ("Zivilisation und Erfindung", in Merkur XV, 1961, 214s.) compara as leis de Malthus (incremento da população) e de Parkinson (incremento do trabalho): "O trabalho alcança, automaticamente, uma quantidade tal que preenche o tempo disponível." "Não creio que a população nos países altamente civilizados cresça de tal maneira que alcance o limiar da fome. Parece-me, no entanto, que tenha, sim, a tendência de crescer até um nível suficiente para afastar o pesadelo de uma vida de ócio para todos."
} 
justificatória e uma apropriação a posteriori. Pela minha parte, tentei mostrar que mesmo nesta orientação da investigação há, ao fim e ao cabo, posicionamentos justificáveis e que permitem tomar uma decisão pelos quais se pode optar.

Talvez um caso-limite, de conclusividade, que, após este cúmulo de dificuldades expostas, gostaria de alegar como uma reprise tranquilizadora é o aparecimento da ideia e das primeiras realizações da máquina de calcular, //46 obra de Pascal e Leibniz. ${ }^{28} \mathrm{O}$ facto, que, em princípio, parece paradoxal, de que precisamente tenham sido os filósofos entre os matemáticos - e não os técnicos - que se preocuparam com a construção das primeiras máquinas de cálculo, torna-se plausível se a nova conceção da filosofia sobre o carácter lógico-operativo e o funcionamento automático do pensamento humano é entendida como um pressuposto que obteve na ideia da máquina de cálculo a sua, diríamos, demonstração palpável. O que ativou o desejo construtor não foi, primordialmente, a utilidade de aligeirar de forma mecânica as operações de cálculo, mas o propósito de fornecer o modelo explicativo para essas operações da mente. Queria aduzir, a esse respeito, uma passagem da biografia que Gilberte Périer, a irmã de Pascal, escreveu sobre o seu irmão. Ao falar da invenção daquele jovem de dezanove anos, disse-nos o seguinte: «Com esta máquina aritmética não só podem levar-se a cabo com uma segurança infalível todo o tipo de cálculos sem penas para escrever nem fichas, mas até desconhecendo qualquer regra aritmética. Uma obra assim foi vista como algo inovador no âmbito do natural, ao transpor uma ciência inerente apenas e exclusivamente ao espírito a um determinado mecanismo, dando como resultado um instrumento capaz de realizar, com total //47 segurança e sem necessidade de reflexão, todas as operações. ${ }^{29}$

A traduzibilidade, que assim ficava demonstrada, da teoria num mecanismo refletese num novo conceito da dignidade da mente humana. A máquina automática assume aqueles desempenhos que não necessitam apresentar a suprema qualidade do original, tal como o faz o próprio invento. A tecnificação mostra-se, de forma paradigmática, como o processo em que o ser humano se descarta de trabalhos, que exigem o seu esforço apenas uma única vez.

${ }^{28}$ Cfr. Fleckenstein, J. O., "Die Einheit von Technik, Forschung und Philosophie im Wissenschaftsideal des Barock", in Technikgeschichte 32, 1965, 19-30, particularmente 28.

${ }^{29}$ Vie de Blaise Pascal, ed. E. Havet, Paris 1897, 43: “... cette machine d'arithmétique par laquelle on fait non seulement toutes sortes de supputations sans plume et sans jetons, mais on les fait même sans savoir aucune règle d'arithmétique, et avec une sûreté infaillible. Cet ouvrage a été considéré comme une chose nouvelle dans la nature, d'avoir réduit en machine une science qui réside toute entière dans l'esprit, et d'avoir trouvé le moyen d'en faire toutes les opérations avec un entière certitude, sans avoir besoin de raisonnement." 

Peter Sloterdijk 



\section{O Antropoceno - Estado de um processo à margem da história da Terra? ${ }^{1}$}

\section{$\S 1$ Humanidade sem peso}

Quando o holandês Paul J. Crutzen, químico da atmosfera, propôs, no ano 2000, o termo “Antropoceno" - valendo-se do projeto análogo do geólogo italiano Stoppani (1824 - 1891), formulado em 1873 - para demarcar a era presente a partir do ponto de vista da história da natureza, era de esperar que este termo se mantivesse parte de um discurso hermético, pronunciado no recinto fechado de institutos para a análise de gases ou institutos de geofísica.

Devido a uma série de acasos desconhecidos, este sintético vírus semântico terá conseguido passar as portas bem isoladas dos laboratórios e ter-se-á espalhado no mundo da vida comum - ficando-se com a impressão de que este vírus se reproduz com particular facilidade nos contextos da crítica literária e crítica da arte, dos museus, da macrossociologia, dos novos movimentos religiosos e da literatura ecológica de alerta.

A proliferação do conceito dever-se-á sobretudo ao facto de que ele transmite, sob as vestes da neutralidade científica, uma mensagem de uma urgência moral e política inigualável, uma mensagem que em linguagem explícita é a seguinte: o homem tornou-se responsável pela habitação e gestão da Terra na sua totalidade, a partir do momento em que a sua presença deixou de se realizar no modo de uma integração que, grosso modo, não deixa vestígios. //8

O conceito "Antropoceno", com aparente relevância geológica, implica um gesto que se iria caracterizar, em contexto jurídico, como designação de uma entidade responsável. Ao atribuir responsabilidade, cria-se um endereço aonde se pode dirigir potenciais queixas. É justamente isto que acontece hoje em dia, quando atribuímos "ao homem" - sem acrescento de demais predicados - imputabilidade das suas ações em dimensões geo-históricas.

Quando falamos de "Antropoceno", parece que estamos num seminário académico das geociências, embora, na verdade, nos encontremos num processo no tribunal, mais precisamente, numa audiência preliminar do próprio julgamento, onde está em questão a responsabilidade penal do réu.

Trata-se nesta audiência preliminar da questão se de todo faz sentido abrir um inquérito ao réu quando este ainda é menor. Nestas audiências chamar-se-ia ao tribunal, entre outros, o autor Stanislaw Lem, que parece ilibar "o homem" ao adscrever-lhe, no contexto telúrico, o estatuto de uma quantité négligeable. Citando as próprias palavras de Lem:

${ }^{1}$ Traduzido a partir de: Sloterdijk, P. (2016). Das Anthropozän - Ein Prozeß-Zustand am Rande der Erd-Geschichte? In P. Sloterdijk, Was geschah im 20. Jahrhundert? (pp. 7-43). Frankfurt/M.: Suhrkamp [nota dos editores]. 
Se reuníssemos (...) a humanidade inteira, encurralando-a e comprimindo-a num único sítio, então ocuparia um espaço de trezentos biliões de litros, ou seja, pouco menos de um terço de um quilómetro cúbico. Parece ser muito. Mas os oceanos do mundo contêm um bilião e duzentos e cinquenta e oito milhões de quilómetros cúbicos de água. Portanto, se lançássemos toda a humanidade, estes cinco biliões corpos humanos, ao oceano, o nível do mar subiria menos de um centésimo milímetro. Com este breve salpicar, a Terra estaria de uma vez por todas esvaziada de homens. ${ }^{2} / / 9$

Estando assim como está, em termos quantitativos, não faria diferença se substituíssemos os cinco biliões de homens do cálculo de Lem pelo número atual de sete biliões, ou pelos oito ou nove biliões que alcançaremos em 2050. Sob o aspeto da bio-massividade, a humanidade, seja qual for a velocidade e ratio do seu crescimento, manter-se-á sempre uma quantidade diminuta - posto que se poderia afogá-la toto genere no oceano. Porquê então abrir um processo contra uma espécie que, em comparação proporcional com a principal massa material do sistema Gaia, a água do mundo, apresenta um quase-zero? A posição de Lem está, aliás, em boa companhia com outros clássicos do desprezo do homem - relembro apenas o reparo depreciativo de Schopenhauer sobre a massa humana como estirpe de bolor efémera na superfície do planeta Terra.

A estas objeções, o advogado geral do processo retorquirá que a humanidade agregada não se reduz, no estádio atual da sua evolução, apenas à sua biomassa. O motivo principal de a levar ao banco dos réus é antes o facto de ela representar uma agência metabiológica, cujo potencial de ação é capaz de exercer um impacto sobre o ambiente que não mantém qualquer relação proporcional com a falta de peso físico.

Naturalmente, pensa-se neste contexto logo nas revoluções tecnológicas da era moderna e nos seus efeitos colaterais, colocados não sem razão na conta do coletivo humano. $\mathrm{Na}$ verdade, fala-se aqui apenas da civilização europeia e da sua elite tecnocrática. É esta última que lançou um novo ator ao jogo das forças globais, através do uso de carvão a partir dos séculos XVII e XVIII, e mais tarde de petróleo, em máquinas motrizes de todo o tipo. Para além disso, foi a descoberta e conceptualização da //10 eletricidade pouco antes de 1800 e a sua dominação tecnológica no século XIX que gerou um novo universal no discurso energético, sem o qual já não seria possível imaginar o metabolismo entre homem e natureza - para relembrar a definição de "trabalho" no sentido marxiano. O coletivo, hoje em dia caracterizado com expressões como "humanidade", consiste sobretudo de agentes que se apropriaram, em menos de um século, de tecnologias desenvolvidas na Europa. Quando Crutzen fala do "Antropoceno", estamos então perante um gesto de cortesia - ou de receio de conflitos - neerlandesa. Quanto à causa em questão, seria mais apropriado falar de um "Euroceno" ou de um "Tecnoceno" iniciado pelos europeus.

Que há um impacto do homem sobre a natureza, e não só da natureza sobre o homem, não é nenhuma novidade. Já na Antiguidade houve, na Grécia e na Itália, desflorestamento devido à quantidade necessária de madeira para a construção de navios. Também o desenvolvimento das paisagens culturais europeias é impensável sem ter em conta a influência da agricultura, vinicultura e pecuária. Sobretudo a última é, tanto ontem como hoje, um elemento contabilístico explosivo na conta que o ecossistema "Terra"

2 Stanislaw Lem. Eine Minute der Menschheit. Eine Momentaufnahme. Aus Lems Bibliothek des 21. Jahrhunderts. Übersetzt von Edda Werfel. Frankfurt am Main 1983. 
apresentará ao homem. Mas apenas em tempos recentes se expôs a relação que existe entre o domínio pastoral do homem e o expansionismo político. ${ }^{3}$ Ao que parece existe então um nexo causal entre criação de gado e política imperial que tem vindo a vigorar, do ponto de vista da macro-história, apenas recentemente, ou seja, nos últimos 3000 anos. Não foram poucos os impérios na história - como o dos romanos, dos britânicos, dos Habsburgos e dos americanos - cujo poder se devia ao cultivo dos rebanhos de gado que disponibilizaram aos seus pastores um excedente importante em força de trabalho, //11 mobilidade, proteínas e couro, para não falar do nexo entre garantir da ração diária de calorias e expansionismo político. Desde tempos mais recentes também se sabe que os rebanhos de gado exercem um impacto considerável sobre o ambiente por causa das suas funções metabólicas.

Estima-se o número atual de animais da espécie bovina na Terra em aproximadamente 1,5 biliões. Se os afogássemos a todos eles no oceano, a subida do nível do mar seria o quíntuplo da subida que resultasse do afogamento de todos os homens: ainda que alcançássemos a dimensão de décimos de milímetros, não sairíamos do espectro do peso quasi-nulo.

Contudo, o impacto ambiental indiretamente antropógeno que advém da criação de gado é imponente. Nos três anos da sua vida, cada vaca criada pelo homem liberta, por causa da flatulência gastrointestinal ordinária, uma quantidade de gases de estufa que corresponde ao percurso de 90000 quilómetros, feito com um carro com motor de gama média.

Ao apontar para o poder pastoral humano nas dimensões atuais do seu exercício, saímos do espectro das quantidades negligenciáveis. Enquanto produtora de emissões indiretas em quantidades enormes, a "humanidade" tem, não obstante a falta de peso em termos da sua biomassa, talvez mesmo um papel geo-histórico decisivo, nomeadamente na sua qualidade de operadora de frotas gigantescas de automóveis, aviões e navios à base de motores de combustão, mas também no que respeita à sua gestão térmica em regiões do planeta onde invernos rigorosos obrigam a compensações pirotécnicas e arquitetónicas. Admite-se a abertura do processo judicial sobre o litígio “Antropoceno". //12

\section{$\S 2$ Doutrinas sobre eras mundiais}

Usando o conceito “Antropoceno", a geologia contemporânea reaviva o hábito epistemológico do século XIX que procurava historizar os objetos, quaisquer que fossem, e dividir todos os campos historizados em éones, eras e épocas. A marcha triunfante do historicismo ganhou ainda mais força devido à ideia da evolução que permitia ser aplicada a todos os campos da realidade - dos minerais até aos macro-corpos compostos que se chamam "sociedades" humanas.

Daí que Marx e Engels possam afirmar, em consonância com as ideias do seu tempo: «Conhecemos somente uma única ciência, a ciência da história.» ${ }^{4}$ Portanto, na sua perspetiva, a história da humanidade constitui apenas um caso específico da história da natureza, na medida em que o homem per se é o "animal" que deve assegurar a sua existência por meio da produção. A história das "relações de produção” seria assim nada

\footnotetext{
${ }^{3}$ Jeromy Rifkin, Beyond Beef. The Rise and Fall of Cattle Culture, New York 1993.

${ }^{4}$ Karl Marx, Friedrich Engels, Die deutsche Ideologie. Marx-Engels-Werke 3, Berlin 1969, p. 18.
} 
mais do que a continuação da história da natureza num registo diferente. O metanaturalismo humano seria apenas a história da natureza tecnologicamente alienada. Aquilo que chamamos "natureza" interior do homem, seria então o impulso, designado por Espinosa de conatus, da autopreservação a qualquer preço que impõe a toda a vida os moldes de uma fuga para a frente.

A visão do mundo marxista deu, durante um certo tempo, popularidade à saga das relações de produção - inclusive os seus macro-estádios que vão da era dos caçadores e recoletores, das sociedades esclavagistas, do feudalismo e do capitalismo até ao "comunismo". A este mito cabe o grande mérito de ter substituído as antigas doutrinas dos tempos do mundo ou //13 éones - descendendo da era dourada à era férrea - e a doutrina dos impérios segundo o livro bíblico de Daniel por uma teoria epocal pragmática. Segundo esta leitura, as épocas distinguem-se umas das outras pelo modo como os homens organizam o seu "metabolismo com a natureza".

O conceito "Antropoceno" pertence, no que à sua gramática lógica diz respeito, às teorias pragmáticas dos tempos do mundo. Ele compreende e constata um estado do metabolismo telúrico no qual as emissões efetuadas pelo homem começaram a ter um impacto no curso da "geo-história". O conceito "emissão" dá a entender que a influência se tenha realizado, até agora, no modo do "efeito colateral" - caso contrário falar-se-ia de uma "missão" ou de um "projeto". O "e" da palavra "emissão" assinala o carácter involuntário do impacto antropógeno sobre a dimensão exo-humana. O conceito "Antropoceno" contém daí nada menos que a tarefa de examinar se a agência "humanidade" está em condições de fazer de um ejeto (ejeção) um projeto, ou seja, de transformar uma emissão numa missão.

Quem usa, portanto, o termo "Antropoceno", apela a uma "Crítica da razão narrativa” ainda mal existente. Visto que narrativas eficazes apenas podem ser construídas a partir do seu desfecho, o ponto de vista da narrativa antropocénica tornar-se-á idêntico a uma forte opção moral. Na tradição narrativa do Ocidente, esta posição estava reservada exclusivamente à literatura apocalíptica. Entenda-se por apocalíptica a tentativa de avaliar o mundo a partir do seu fim, ou seja, o Apocalipse implica um processo de triagem cósmicomoral onde se separam os bons dos maus. Separar os bons dos maus não quer dizer outra coisa do que separar os dignos de sobrevivência //14 dos não dignos de sobrevivência: ao que se chama vida eterna não é senão uma expressão metafisicamente sobreaquecida para "ter licença para continuar", ao passo que condenação eterna significa que um determinado modus vivendi não tem futuro, podendo ser descartado da série das formas de viver dignas de trasladação.

Destarte, tudo aponta para que o conceito "Antropoceno" deva ser entendido como expressão que apenas faz sentido nos moldes de uma lógica apocalíptica. Apocalipse significa então: evidência obtida a partir do fim. Mas visto que nós, enquanto entidade coletiva, nunca podemos estar definitivamente no fim, tendo, por enquanto, que continuar de uma forma qualquer, a inteligência humana não pode acabar o estudo retrospetivo da história de forma conclusiva. Apenas pode ensaiar este estudo por meio de antecipações diversas - o que foi demonstrado na ilustre série de simulações, ora sublimes ora profanas, que começa com os Livros dos Mortos egípcios e estende-se ao primeiro relatório do Club of Rome. 
A atual interferência do homem na história da natureza demonstra que a ideia inicial de Heidegger de entender o ser como tempo era inteiramente correta. A esta intuição heideggeriana faltava, porém, um momento essencial: que só se atenta no tempo enquanto tempo quando este for perturbado no seu fluxo homogéneo.

O tipo de perturbação em que os antigos repararam primeiro foi o atraso - que fornece uma das formas fundamentais da tragédia. Também a humanidade atual é ameaçada por atrasos, nomeadamente no que respeita à tomada de medidas na "política ambiental". Em geral, porém, atenta-se no fenómeno do tempo, nomeadamente na época moderna, devido a acelerações. Aceleração até ao limite extremo do curso do movimento é o movens do Apocalipse enquanto figura lógica do tempo. Heidegger derivou desta figura o conceito intelectual do "percorrer antecipativo da própria morte" - aceitando o encurtamento existencialista como preço a //15 pagar por esta antecipação do fim. A verdadeira tarefa para o pensamento, no entanto, teria sido já no tempo de Heidegger analisar por que é que a modernidade, devido a razões imanentes, se orienta na antecipação de um fim completo. Esta análise teria exigido, por seu turno, uma investigação dos motivos para a aceleração dos processos em geral que impôs ao modus vivendi dos modernos a forma de um adiante absoluto.

\section{$\S 3$ Modernos círculos de sucesso}

Quem perguntar pelo movens da aceleração tipicamente moderna, reparará nos mecanismos do feedback positivo para os quais o sociólogo americano Robert K. Merton sugeriu o termo "efeito Mateus", aludindo a uma passagem conhecida do Novo Testamento. Na palavra de Jesus, «Àquele que tem, dar-se-lhe-á mais, e terá em abundância; mas ao que não tem, até o que tem, ser-lhe-á tirado.» (Mt, 25,29), é antecipada intuitivamente a lógica do sistema de um feedback auto-intensificador. Efeitos deste tipo impõem às modernizações típicas a forma de um circulus vitiosus ou, respetivamente, de um círculo de sorte. Embora a modernidade seja também marcada pela ocorrência de circuli vitiosi horrendos, o conjunto e respetivo desenvolvimento de todos os círculos apontará para a predominância das conexões do tipo de círculos de sorte, cujo efeito resulta numa nova aperceção do tempo.

Mencionemos seis destes processos de feedback auto-intensificadores imbricados entre si em múltiplos processos de efeitos recíprocos: as belas artes, o crédito bancário, a engenharia mecânica, o sistema político, a investigação científica e o sistema jurídico. //16

No que respeita às belas artes, verifica-se no espaço europeu, a partir do século XIV, o surgimento de uma organização historicamente inédita e completamente nova. Ao que se chama Renascença é a consequência de um processo secular de auto-intensificação da habilidade do artífice, nas oficinas de arte do norte de Itália, na Flandres e na Alemanha, chegando ao cume, graças à continuidade de círculos positivos de efeitos recíprocos e intensificado pela concorrência vigente e pela espionagem, nos séculos XVI e XVII, quando se alcança um nível supremo de mestria inigualável - basta mencionar nomes como Ticiano, Caravaggio ou Rembrandt para entender como a destreza artesanal penetrou no estratosférico. Após a sua instalação nas oficinas de modestos mestres do século XIV, o círculo vicioso tomou o seu feliz rumo ascendente nas artes da modernidade, desde que 
fossem artes virtuosas. Com as artes contemporâneas e a sua entrada na era da arte global impuseram-se, no entanto, os padrões do mercado mundial das produções pós-virtuosas.

Ocorrências análogas podemos encontrar no campo dos efeitos recíprocos positivos ao que se costuma chamar economia. Também neste campo foi ativado, a partir dos séculos XIV e XV, um poderoso circulus vitiosus. Foi devido a ele que se formaram da relação entre crédito e talento - entendida a última palavra na aceção moderna - grandes fortunas, e de modestos capitais iniciais empresas de alcance internacional.

A dinâmica auto-intensificadora da arte de gestão empresarial nesta parte do mundo teria, no entanto, parado no nível de uma economia manufatureira, tal como aconteceu na China tradicional, se não tivesse havido, na viragem do século XVII para o XVIII, a cooperação com o impulso de uma dimensão adicional //17 de processos recíprocos autointensificadores. Estamos habituados a atribuir a esta esfera nomes abreviados como engenharia mecânica ou construção de máquinas, e quem preferir manter-se na irreflexão, pode simplesmente dizer "técnica". A estreita aliança entre os segundo e terceiro círculos de sorte, ou seja, entre a economia impulsionada pelos juros e a engenharia mecânica impulsionada pelas inovações, teve como resultado o monstro dinâmico ao qual se deu, devido a uma preguiça acostumada desde o século XIX, o desajeitado nome de "capitalismo" - que teria de ser substituído, desde o início, por "creditismo" ou "invencionismo", se o facto de encontrar um nome certo tivesse sido importante. Deste monstro que se auto-procria fala Schumpeter quando, no ano de 1912, anota a frase aparentemente inócua, mas no fundo profundíssima: «O desenvolvimento cria, sempre de novo, mais desenvolvimento.»

Esta constatação deixa-se relacionar igualmente bem com o seguinte círculo autointensificador, que se formou no sistema político moderno. Desde os seus penosos começos na época das guerras confessionais o moderno Estado administrativo, social e fiscal tem criado um efeito Mateus de um tipo próprio, ao gerar, obedecendo à lógica da feliz expansão da auto-atividade, incessantemente novas responsabilidades e competências, novas autorizações de intervenção para si próprio. Neste âmbito, convém lembrar a lei de Wagner, também conhecida como "lei da quota crescente do Estado" ou "lei da constante expansão da ação de Estado" - duas observações que aliás foram consideradas positivas na opinião do seu criador, o bem conservado otimista do progresso e professor numa cátedra berlinense Adolph Wagner (1835-1917). Wagner, protótipo dos mais tarde fortemente polemizados "socialistas de cátedra", teve //18 o dom de enquadrar a expansão autógena das ações de Estado nos moldes da satisfação das necessidades das comunidades, ao passo que nós, hoje em dia, não podemos evitar uma certa distância cética face ao emaranhado entre estatismo, fiscalismo e intervencionismo que nos parece ser cada vez mais um espetáculo absurdo de uma macro-instituição contra-produtiva que se serve a si própria.

Para além disso, merece uma menção própria o círculo auto-intensificador da hodierna indústria cognitiva. Hoje em dia, cada criança em idade escolar sabe que os nossos tempos são tempos de investigação - e são-no desde que Bacon escreveu o seu Novum Organon [sic.], apelando à deusa da experiência para aumentar o conhecimento nononsense e os saberes comprovados da humanidade, e desde Leibniz se propôs promover a criação de academias para que a investigação tivesse um lar próprio comprometido exclusivamente com a busca de novas verdades. De facto, não há característica mais influente do mundo em que vivemos do que o facto de nos ter tornado num país de 
imigração para conhecimentos recentemente adquiridos. Por muito esquisito que soe, isto deve ser dito assim porque a investigação moderna não se compara a um armazenamento de conhecimentos distintos e separados para o agrado de almas contemplativas. Investigação significa per se a geração de um acréscimo de conhecimento através do conhecimento. O típico conhecimento moderno que circula em circuli vitiosi para se reproduzir constantemente é, para além disso, sobretudo conhecimento prático e daí um tipo de verdade que procura ser aplicada. Está à espera de se infiltrar, no momento oportuno, nos mundos da vida das populações modernas. Existimos num tipo de realidade que se caracteriza pela imigração mal controlada de aliens epistémicos e tecnológicos; esperemos //19 que estes novos concidadãos do environment cognitivo provem, a longo prazo, que são vizinhos civilizados.

Com isto chegamos ao último circulus vitiosus da nossa enumeração, se bem que não seja o último ou mais fraco de acordo com o seu efeito. É do sistema jurídico na sua constituição sistémica atual que falamos. Apenas na Europa agitada pelos tempos modernos, já envolvida em jogos auto-intensificadores de toda a espécie, podia surgir a arrojada e aventurosa ideia de que os homens são seres com direitos inalienáveis - mais ainda, que a própria vida é nada mais do que a fase de sucesso dos titulares de direitos ao fazerem valer estes direitos. Embora os homens desde sempre tenham procurado proteção em construções locais de justiça, é certo que somente na Europa, terra-mãe do efeito Mateus, se podia desenvolver o círculo que advém do meta-direito por excelência, o "direito a ter direitos", para citar uma formulação de Hannah Arendt que capta exatamente aquilo que é o germe da expansão da esfera jurídica. Apenas numa civilização onde o direito a ter direitos se tornou atitude interiorizada e instituição suportada por órgãos estatais, se podia pôr em marcha a espiral de uma juridificação cada vez mais extensa que se tem tornado o padrão por excelência da dinâmica social nos últimos séculos. Esta expansão do campo de tudo aquilo sobre o que se pode adquirir um direito lança, no entanto, uma sombra problemática crescente. Através do intenso efeito recíproco entre a ilimitada criação de direitos e o sistema auto-intensificador gargantuesco das estruturas do Estado foi-se criando, nos nossos dias, um monstro de uma jurisdição regulamentadora nacional e internacional para a qual não há comparação na história. //20

Todos estes mecanismos dão o seu contributo para a crescente significância da dimensão temporal, na medida em que colocam a inteligência previdente perante a tarefa de realizar o percorrer antecipativo da morte não apenas individualmente, enquanto seres mortais individuais, mas antes para o conjunto das configurações no seu todo, ao que se chama a "sociedade moderna".

\section{$\S 4$ A crise da forte externalização}

Cunhar o conceito "Antropoceno" obedece, portanto, inevitavelmente a uma lógica apocalíptica: indicia o fim da despreocupação cosmológica que constitui o fundamento das formas históricas do estar-no-mundo humano. Poder-se-ia descrever a tradicional "posição do homem no cosmos" - para lembrar o tratado de Scheler - como uma espécie de ontologia 
paisagística. Nesta, o homem age como animal dramático perante o maciço de uma natureza destinada ao seu papel de pano de fundo onde decorrem as operações humanas. $\mathrm{O}$ pensamento nos moldes desta ontologia paisagística ainda se mantém em vigor após a revolução industrial, se bem que a natureza "pano de fundo" passe a ser entendida como depósito integral de recursos e aterro universal.

A possibilidade de os recursos esgotarem é tida em conta apenas muito tarde: foi o químico alemão Wilhelm Ostwald (1853-1932) o primeiro a considerar explicitamente, na sua obra Der energetische Imperativ ${ }^{5}$ de 1912, a limitação dos recursos terrestres, implicando desde já uma viragem do ponto de vista ao criticar a indústria e o Estado: uma vez que não se pode criar numa base finita um superestrutura infinita, deve apelar-se à humanidade a orientar-se a partir de agora num ethos novo do uso da natureza - o //21 imperativo energético chama-se frugalidade: "Não desperdices nenhuma energia, mas usaa!” E uma vez que as guerras constituem a pior forma de desperdício de energia, deveriam ser eliminadas do repertório das atitudes da humanidade - um argumento a que não falta a ironia dois anos antes do começo da Primeira Guerra Mundial. No tratado de Ostwald começa a fazer-se sentir aquela "analítica da finitude" que será transferida pouco depois, por Heidegger, da esfera das ciências naturais para a dimensão existencial. Também a frase mais conhecida de Max Weber que consta da parte final de Die protestantische Ethik und der Geist des Kapitalismus ${ }^{6}$, de 1920, contém uma resposta indireta à ética da frugalidade para seres finitos num mundo finito de Ostwald: Max Weber constatava que a ordem económica de então aprisionava os seres humanos num «invólucro de aço», determinando-os «com uma força coerciva insuperável, não só agora, mas talvez até ao momento em que queimará o último quintal de combustível fóssil.» 7 O testemunho de Werner Sombart fornece-nos uma versão mais dramática da mesma ideia: Weber, assim relata Sombart, ter-lhe-ia dito, aquando das suas conversas, que o capitalismo não terminaria antes de se ter fundido «a última tonelada de mineiro com a última tonelada de carvão.»8 Quão presa ao seu tempo esta constatação é - e não apenas pelo facto biográfico de se tratar de um diálogo interior com Ostwald - revela-se na identificação do capitalismo com a indústria pesada de estilo antigo e na omissão dos novos agentes que ganharam os primeiros contornos por volta de 1920 no palco sócio-industrial: petróleo, química, capital financeiro, tecnologia solar e telecomunicação. A fala das "últimas toneladas" //22 mostra bem claramente a lógica apocalíptica do raciocínio weberiano: graças ao seu veloz percorrer antecipativo da morte do sistema, o nosso sociólogo melancólico alcança uma visão sinóptica sobre o "capitalismo" enquanto fatalidade de dimensão mundial.

A substituição da tradicional ontologia paisagística por uma lógica ecológica remonta aos meados do século XIX. Já em 1845/47, Marx e Engels postularam no seu tratado Die deutsche Ideologie ${ }^{9}$ de uma forma sumária uma história comum do homem e da natureza, embora tenham logo a seguir excluído a história da natureza das suas considerações, visto que bastaria concentrar-se no estudo das formações históricas das "relações de produção". Esta exclusão é característica para uma época em que a diferença entre produtos

\footnotetext{
${ }^{5}$ O imperativo energético [nota dos editores].

${ }^{6}$ A Ética Protestante e o Espírito do Capitalismo [nota dos editores].

${ }^{7}$ Max Weber, Die protestantische Ethik. Eine Aufsatzsammlung, München und Hamburg 1965, p. 188.

8 Werner Sombart, Das Wirtschaftsleben im Zeitalter des Hochkapitalismus, München / Leipzig 1927, p. 1010.

${ }^{9}$ A Ideologia Alemã [nota dos editores].
} 
intencionalmente feitos e efeitos colaterais não intencionados ainda não se mostrou em toda a sua profundidade e polémica, o que iria acontecer apenas no final do século XX. No seu gaio produtivismo, Marx e os seus sucessores continuavam a sustentar uma ontologia paisagística, segundo a qual a natureza interpretada como recurso seria capaz de absorver também no futuro a externalização dos efeitos da produção industrial, sem que se desse conta disso. A assunção feita sobre a tolerância ilimitada da natureza externa fez com que a despreocupação cosmológica dos homens após a revolução industrial tivesse sobrevivido muito mais tempo do que seria oportuno devido à alvorada da crescente consciencialização da problemática ambiental. Com o fim da despreocupação, também a ontologia paisagística e com ela a distinção habitual e há muito petrificada entre primeiro plano e segundo plano deixará de ser plausível. //23

\section{$\S 5$ Gestão da ignorância}

No seu célebre Manual de Instruções para a Nave Espacial Terra, publicado no original em 1968, Buckminster Fuller sustentou a suposição arrojada e, de facto, utópica, de que chegou o momento de tirar as competências de governação aos políticos e financeiros e entregá-las aos designers, engenheiros e artistas. Esta suposição baseava-se no diagnóstico segundo o qual os membros do primeiro grupo olham para a realidade, tal como todos os "especialistas", sempre apenas através de um pequeno buraco, o que não permite ver mais do que um setor parcial. Ao invés disso, os últimos desenvolveriam, devido à sua profissão, perspetivas holísticas, tendo em conta o panorama da realidade inteira.

Era como se o lema "A fantasia ao poder!" tivesse atravessado o Atlântico e, ao chegar à outra costa, tivesse sido decifrado como "O design ao poder!". A ousadia da publicação de Buckminster Fuller, que rapidamente se tornou a Bíblia da "cultura alternativa" e doravante dos "movimentos sociais", não se caracterizou pelo desprezo dos grandes e poderosos do mundo. Estes, assim Buckminster, "passaram a transformar-se em sombras de si mesmo.» A verdadeira ousadia residia antes na nova e revolucionária definição do nosso planeta: a partir de então já não se deve representar a nossa velha Terra como unidade natural, mas antes como uma gigantesca unidade artificial. Deixou de ser fundamento e tornou-se constructo, deixou de ser base e tornou-se meio de transporte.

Fala em abono da desmesura e irresistibilidade da metáfora de Buckminster Fuller como esta invadiu, em pouco menos de meio século, a nossa consciência coletiva. //24 É também sintomático para o atual estado de emergência a bordo da nave espacial Terra que este não permita socorrer-se de vaguidades poéticas na falta de conceitos mais precisos, facto corroborado pelo inegável insucesso das numerosas "cimeiras climáticas". A metáfora constitui, neste caso, a forma superior do conceito. A sua verdade mostra-se pela adequação das suas implicações face à situação real. Sendo a Terra uma nave espacial, a sua tripulação deve focar o seu interesse em primeiro lugar na manutenção das condições de sobrevivência no interior do veículo - os engenheiros aeronáuticos falam neste âmbito do Life Support System (LSS) que a bordo de estações espaciais desempenha o controlo das constantes biosféricas reproduzidas. Gestão da atmosfera passa a ser a partir de então o primeiro critério da arte de governação da nave espacial integral, arte essa que se deve tomar em 
consideração a partir de agora, nomeadamente em relação ao seguinte: nesta nave não há máscaras de oxigénio que caem do teto automaticamente na "escassa eventualidade" de haver falta de ar; seria igualmente absurdo dizer que há faixas iluminadas no chão que indicam o caminho para as saídas de emergência, pois a nave espacial Terra não dispõe de portas de saída, nem para casos de emergência nem para a situação normal. E no que respeita às faixas iluminadas no chão, que mais é que são do que uma hipnose suave para passageiros com medo de voar? O medo dos passageiros a bordo da nave espacial Terra precisa de remédios mais concretos. Tratar deste medo necessita de procedimentos cognitivos e tecnológicos revolucionários.

Buckminster Fuller designou muito precisamente a condição até agora mais importante da estadia de homens a bordo da nave espacial Terra: os passageiros não possuem nenhum manual de instruções, talvez porque devam eles mesmos descobrir o segredo da sua situação. De facto, a Terra tem sido habitada, desde há quase dois milhões de anos, //25 por homens e predecessores de homens que «nem sequer sabiam que estavam a bordo de uma nave.»10 Dito de outro modo: no passado, as navegações dos homens eram compatíveis com uma elevada percentagem de ignorância uma vez que o sistema permitiu a existência de graus elevados de desorientação humana. Mas na medida em que os passageiros começam a descobrir o segredo da sua situação e exercer através da tecnologia o domínio sobre o seu meio ambiente, diminui a margem de tolerância do próprio sistema relativamente à ignorância, até que se chegue ao ponto em que certas formas de atitudes ingénuas já não são compatíveis com a estadia dos passageiros a bordo. $\mathrm{O}$ estar-no-mundo do homem, do qual falou a filosofia do século XX, revela-se afinal como um estar-a-bordo de um veículo cósmico sujeito a avarias. Propus recentemente o conceito de "monogeísmo" para a representação adequada da relação cognitiva entre o homem e esta configuração, um termo que designa, por assim dizer, o mínimo da relação atual e ao mesmo tempo não ignorante perante a primazia da Terra. Constitui, simultaneamente, o axioma de uma ontologia política da natureza.

Do ponto de vista atual, a história do pensamento no planeta revela-se como experimentação cognitiva e pragmática finalizada, no âmbito da qual a verdade sobre a situação global tinha de vir à luz. Quem a bordo da nave espacial tiver a coragem de usar a sua própria razão, deverá mais cedo ou mais tarde prestar contas relativas ao facto de que somos autodidatas da aeronáutica. Daí o verdadeiro conceito da conditio humana ser: autodidática - questão de vida ou de morte. O autodidata tem de aprender as lições essenciais //26 sem a ajuda de um professor. E devo acrescentar que o mero recurso a tradições religiosas se revela neste âmbito como meio de ajuda insuficiente porque vinculado sem exceção a um entendimento do mundo pré-astronáutico, e mesmo Jesus não pôde contribuir em nada para um manual de instruções da nave espacial Terra.

Associada a estas observações encontra-se uma afirmação sobre a relação entre ser e conhecer: o conhecimento tradicional está essencialmente em atraso em relação à realidade, ou seja, podemos dizer que chega por princípio atrasado. Sendo assim, somos levados à pergunta se o principal atraso do conhecimento nos obriga a inferir que este, também no que respeita aos problemas futuros, virá necessariamente tarde demais. Felizmente estamos em

${ }^{10}$ Buckminster Fuller, Bedienungsanleitung für das Raumschiff Erde [Manual de Instruções para a Nave Espacial Terra], Dresden e Amsterdão 1984, p. 46. 
condições de dar uma resposta negativa a esta pergunta. Há uma inteligência prognóstica que se faz valer exatamente na lacuna que existe entre "tarde" e "demasiado tarde". É esta inteligência que se deveria articular aqui e agora vigorosamente. Quando até agora valia, para a maior parte da aprendizagem humana, a lei de que aprendemos apenas "à custa dos danos”, urge que a inteligência prognóstica se torne prudente antes de haver danos, o que é algo inédito na história da didática. Para penetrar na lógica de tais processos de aprendizagem é necessária uma crítica da razão profética. Esta não se deve deixar intimidar pelo paradoxo basal do profetismo apocalíptico: caso tenha sucesso, parecerá ex post como uma advertência desnecessária, simplesmente porque devido à sua interferência não aconteceu nada daquilo para que fomos alertados. Esboços de uma tal crítica apresentou, em 2004, Jean-Pierre Dupuy em Pour un catastrophisme éclairé. Segundo este estudo, apenas os apocalípticos experientes podem fazer uma //27 política de futuro por que são suficientemente corajosos ao pensar o pior como possibilidade real.

Tornar-se prudente significa hoje sobretudo: que o expressionismo cinético dos últimos séculos deve ser mudado radicalmente, ainda que não possa ser sustido. Por expressionismo cinético entendo o estilo da vida dos modernos que foi tornado possível devido à fácil disponibilidade de combustíveis fósseis. Desde que estes recursos chegaram às mãos de praticamente cada um, levamos uma vida como se Prometeu tivesse roubado o fogo pela segunda vez. O que isto significa torna-se claro quando admitimos que estes fogos secundários não só acionam os nossos motores, mas que ardem também nas nossas motivações existenciais e nos nossos conceitos vitais de liberdade. Já não podemos pensar em liberdade sem incluir sempre também a liberdade para acelerações arriscadas, a liberdade de livre movimentação até aos lugares mais longínquos, a liberdade de exagerar e desperdiçar, e ao fim e ao cabo também a liberdade para fazer explodir e para a autodestruição. O expressionismo cinético já falou quando o jovem Goethe da fase de Sturm und Drang escreveu, em 1776, numa carta a Lavater: «Embarquei definitivamente na onda do mundo - inteiramente determinado a descobrir, vencer, lutar, naufragar, ou acionar os explosivos que, junto com a carga toda, me reduzem a pó.» Já falou quando Nietzsche exclamou em Ecce Homo: "Não sou homem, sou dinamite.» E vemo-lo em ação, quando Phileas Fogg, o herói em A Volta ao Mundo em 80 Dias de Jules Verne, na última parte da sua circunavegação da Terra - na travessia do Atlântico de Nova Iorque a Inglaterra começa a derrubar todas as construções de madeira do seu navio quando esgotou o carvão, usando-as para alimentar as câmaras de combustão das maquinas a vapor. Jules Verne encontrou com a imagem do navio que se queima a si mesmo //28 nada menos do que uma metáfora mundial para a era industrial, evocando a autorrefencialidade fatal de um trânsito que queima os seus próprios recursos. Temos de remontar ao poeta romântico Novalis e à sua visão crítica do "moinho que se mói a si mesmo" para encontrar uma imagem de semelhante pregnância para a descrição do modus vivendi atual. Mas o expressionismo cinético está, já antes, presente no gesto da rainha Elisabete I da Inglaterra quando repousa, como mostram os famosos desenhos à estampa do século XVI, a sua mão de soberana no globo do mundo, como se quisesse mostrar que começou uma era na qual os donos do mundo já não se contentam com os seus próprios terrenos, querendo estender o seu poder até aos cantos mais longínquos do mundo. $\mathrm{O}$ expressionismo torna-se político quando o sujeito que se quer autorrealizar reclama os bens da Terra inteira para os seus desejos e o seu 
consumo. O princípio do crescimento, constitutivo para as formas de vida modernas não é senão expressionismo cinético em ação.

\section{$\S 6$ "Estamos numa missão"}

«Estamos numa missão: somos chamados à formação da Terra.» Novalis

O expressionismo dos modernos baseia-se numa suposição que era para os homens de tempos anteriores tão evidente que praticamente nunca chegou a ser formulada explicitamente. Para eles, a natureza era uma entidade exterior com ilimitada robustez, absorvendo todas as descargas e ignorando todas as explorações humanas. Esta ideia espontânea sobre a natureza determinou a história da humanidade até muito recentemente, //29 e ainda hoje há inúmeros contemporâneos que não podem e não querem imaginar que neste aspeto seja necessária uma mudança de atitudes. O desenfreado traço expressionista do estilo de vida das civilizações ricas contemporâneas tornou, porém, claro que a indiferença da natureza face às agitações humanas foi uma ilusão típica para a era da ignorância. Há limites para a expressão, limites para as emissões, limites para a tolerância da ignorância, e uma vez que existem tais limites, ainda que não saibamos onde traçar exatamente as linhas fronteiriças, começou a abalar a ideia imemorial da natureza como exterioridade omni-absorvente. De repente vemo-nos obrigados a acolher a ideia aparentemente antinatural de que a esfera terrestre se transformou devido à praxis humana num único gigantesco interieur. Buckminster Fuller quis outorgar a responsabilidade para esta viragem aterradora às mãos dos designers dos quais exigiu um modo de pensar "abrangente" e "antecipatório". Um tal pensar deveria possibilitar o "planeamento do mundo" no "sistema comunicativo total do homem" na nave espacial Terra.

Passados quarenta anos após a publicação do manifesto de Buckminster Fuller verifica-se que não foram os designers os mais importantes na realização da ideia do mundo qua macro-interior, mas antes os meteorologistas. Para nós é evidente: não é o design, mas a meteorologia que chegou ao poder. Ela obteve reconhecimento político e científico porque oferece o modelo atualmente mais sugestivo do interior global: trata do contínuo dinâmico da esfera gasosa da Terra a que chamamos, desde os dias dos físicos gregos, atmosfera, o que literalmente significa esfera vaporosa. As conversas sobre o tempo deixaram de ser conversações inócuas //30 desde que os cientistas do clima demonstraram que a atmosfera tem uma memória: ainda não esqueceu completamente o fumo das chaminés da primeira revolução industrial e não vai ignorar nada daquilo que as centrais de carvão dos países desenvolvidos, as centrais de aquecimento das megacidades, os aviões, os navios, os carros dos abastados e as inúmeras chamas de todos os continentes emitem, ainda que mais de metade destas emissões costumem ser absorvidas pelos oceanos e pela biosfera. De facto, estes não são os únicos relictos da natureza duvidosa do homem que a Terra guarda: ainda hoje em dia se encontram ferraduras na lama do norte da Alemanha que provam a passagem da cavalaria romana. O solo alemão não se importará muito com a presença das ferraduras romanas. A atmosfera terrestre, no entanto, é um aterro sensível, pois está inclinada a responder a emissões passadas e atuais com um aumento de temperatura. Se os 
meteorologistas dizem a verdade, a expectável alteração do clima levará em muitas partes do globo a condições não compatíveis com a existência humana assim como a conhecemos.

Destarte, os meteorologistas passaram a desempenhar a função de reformadores. Transmitem aos homens dos países industrializados e das nações emergentes o apelo à inversão do seu estilo de vida. Exigem nada menos do que uma descarbonização da civilização a médio prazo e o abandono de praticamente todas as amenidades do modus vivendi baseado na energia fóssil.

A cisão que estes postulados implicam é tão profunda que me parece legítimo estabelecer analogias em sentido lato: a mudança das atitudes exigida vai muito além das reformas do século XVI, //31 ainda que nestas se tenha procedido a uma revisão das regras do intercâmbio entre Terra e Céu. Relembra muito mais a voz de João Batista que apela a uma mudança radical. A voz no deserto exigia nada menos do que uma metanoia capaz de incentivar à substituição do ethos egoísta do dia-a-dia pelo estado de emergência moral do coração. Este chamamento veio a desencadear a revolução à que chamamos cristianismo. Além disso, o apelo atual à mudança de atitudes lembra também a observação sutil de Platão no seu diálogo O Sofista, de que a disputa entre os amigos das ideias (vulgo os idealistas) e os amantes dos corpos sensíveis (vulgo os materialistas) sobre o sentido do ser se compara a uma luta entre gigantes, uma luta que, devido à natureza controversa do assunto, dura tanto tempo quanto há homens que tomam esta ou outra posição.

A luta atual pelo clima já não tem por objeto o “domínio sobre a Terra”, assunto preferido dos comentadores políticos da era imperialista. Trata-se antes da possibilidade de manter aberto o processo da civilização e garantir a sua continuidade. Após a descoberta recíproca das culturas através das deslocações de longo curso entre os séculos XVI e XX, este processo teve como impacto uma síntese provisória dos agentes globais através do comércio e da diplomacia. Parte-se do pressuposto que este processo será intensificado no próximo futuro, no sentido de uma colaboração positiva das culturas em instituições operacionais comuns, deixando de lado a questão se "a humanidade" de todo será capaz de formar um "nós" coerente ou uma volonté générale apta a agir.

Neste momento, apenas duas coisas são certas: por um lado, //32 que as reformas, cujos começos estamos a viver, abrem uma perspetiva para uma era de maiores conflitos; por outro lado, que o século XXI entrará na história como feira de vaidades da redenção, e quando terminar, os homens aspirarão por uma redenção da redenção e por serem salvos dos salvadores. Este século anuncia-se também como era da hipocrisia e duplicidade moral. Não obstante o imperar da vaidade, do pânico e da retórica hipócrita, tratar-se-á nesta era sempre da questão séria se é possível instaurar na nave espacial Terra algo como um regime estabilizador global. Contudo, teremos de ter em conta que as expectativas associadas ao conceito de estabilização devam, desde o início, manter-se moderadas. A evolução cultural não conhece nenhum equilíbrio estável. Na melhor das hipóteses, pode transitar de um estádio de desequilíbrio, sustentável para a vida, ao seguinte.

Já hoje se mostram os contornos da futura gigantomaquia. Nela, o partido idealista ganhará o seu perfil pelos representantes de uma nova sobriedade. Desafiarão os seus adversários materialistas através da exigência de reduzir todas as formas do expressionismo cinético a um mínimo geopoliticamente tolerável. Quando compreendemos que este 
expressionismo é idêntico ao modus vivendi das culturas de bem-estar deste planeta, que permeia a totalidade do nosso "metabolismo com a natureza", do nosso produzir, consumir, habitar, trânsito, das nossas artes e comunicações e que as premissas em todas estas áreas ainda estejam, imperturbavelmente, comprometidas com o crescimento e a superação de metas, então percebemos uma coisa imediatamente: a ética futura, adversa ao expressionismo e às emissões, conduz diretamente à meta da inversão do rumo que a civilização até agora tem perseguido. Exige a diminuição onde o crescimento estava no plano, //33 exige a minimização onde se pretendia a maximização, quer a contenção onde estava permitida a explosão, prescreve a frugalidade onde vigorava o desperdício como estímulo máximo, reclama a autolimitação onde se festejava a autolibertação. Se pensarmos estas inversões até ao seu fim, chegaremos no decurso desta reforma meteorológica a uma espécie de calvinismo ecológico que se baseia no axioma seguinte: a humanidade dispõe apenas de uma única Terra. Daí que não deva exigir dela mais do que é capaz de dar, sob pena da autodestruição. Destarte, a globalização surte paradoxalmente efeitos que contrariam a sua própria tendência base: ao impor em toda a linha as expansões, ela obriga em toda a linha a restrições. Ao querer generalizar a prosperidade, ela descobre que, afinal, apenas o seu contrário é praticável: a frugalidade para todos.

Estas observações já deixam prever quais os gigantes que se combaterão no século XXI. Presenciaremos a luta entre expansionismo e minimalismo, e estaremos impelidos a escolher entre a ética pirotécnica e a ética ascética. Sentiremos como as alternativas contendentes se refletem nos nossos sentimentos vivenciais e como oscilamos entre o desperdício maníaco e a frugalidade depressiva. Nietzsche fez ocasionalmente o reparo de que a Terra deveria parecer a uma inteligência externa como "astro ascético" onde lidera uma elite de espiritualistas depressivos movidos pelo ressentimento. Desde o século XX vivencia a parte abastada da Terra um intermezzo hedonista que antes do fim do século XXI já terá terminado.

Se a anunciada reforma levasse a um socialismo meteorológico, //34 enxergar-se-ia a Terra, a partir da perspetiva externa, como astro frugal. Cada indivíduo teria permissão para gerir um modesto saldo de emissões, como shareholder da atmosfera e dos restantes elementos. Visto que Nietzsche era ao mesmo tempo perito na questão das lutas entre deuses e gigantes, ele sabia que não há, nos conflitos desta escala, lugar para a neutralidade: «Ah! É o encanto destas lutas que, quem a elas assiste, também as deve fazer!», escreve Nietzsche em Die Geburt der Tragödie aus dem Geiste der Musik [A Nascença da Tragédia no Espírito da Música]. Cada cidadão travará esta batalha entre gigantes no seu próprio coração, e, através das suas decisões de consumo, tornará público em que lado está.

\section{$\S 7$ "O que o corpo é apto a fazer"}

«Ninguém descobriu, até agora, o que o corpo é apto a fazer.»

Espinosa

Chegado a este ponto da nossa análise, parecerá que o puritanismo ecológico é a única moral sensata a bordo da nave espacial Terra. Seja como for que se ajuíze o assunto, uma coisa é 
indiscutivelmente certa: no século XX entrou uma nova figura de imperativo absoluto no mundo: "Tens de mudar a tua vida!" Desde então, esta frase imprimiu-se com irrepreensível autoridade nas intuições éticas de muitos concidadãos. Ela impermeabiliza a nossa consciência com a tarefa vinculativa de criar um modus vivendi que corresponde aos atuais conhecimentos ecológicos e cosmopolíticos da nossa civilização e alcança um nível //35 de evidência comparável com aquele das éticas budistas, estoicas, cristãs, islâmicas e humanísticas que conseguiram e ainda conseguem obter reconhecimento e valorização nos indivíduos e comunidades profundamente arrebatados pelas mesmas. Visto que o novo imperativo apela, como todas as grandes evidências éticas, a todos, a prognóstica de que haverá uma onda crescente de entusiasmo ético é certamente realista. Neste entusiasmo ético unir-se-ão a respetiva vontade de viver com a respetiva sensibilidade para o que é bom e certo, conduzindo a um poderoso entusiasmo porventura de efeito global, dentro e fora das religiões tradicionais. Mas igualmente realista será contar também com uma onda complementar de resignação, de derrotismo e do cínico "depois de nós, o dilúvio".

Uma primeira leitura leva-nos então ao aparente resultado de que o atual imperativo deva conduzir forçosamente à conclusão de uma ética da moderação global. A única questão aberta parece ser se a mudança para a modéstia se efetuará voluntariamente pelas populações das culturas de emissões intensas, ou se os governos dos países ricos - os únicos macro-sistemas aptos a agir enquanto falta uma global governance - mais cedo ou mais tarde se verão obrigados a proclamar no seu território uma espécie de direito ecológico à guerra que permite obrigar àquilo que voluntariamente é impossível de conseguir.

Uma segunda leitura, porém, mostra-nos que as exigências de uma ética da moderação global, para não falar das esperanças por um socialismo climático, são ilusórias. Não apenas nadam contra a corrente poderosa da civilização expressionista, como também não se deixam coadunar com os nossos saberes sobre os impulsos que movem as culturas superiores. Pois estas não são concebíveis a não ser como juntando dois impulsos, o impulso da auto-preservação e o do auto-crescimento. Nesta ligação entre auto-preservação //36 e auto-crescimento está implicada a decisão a favor de uma cultura que confere o direito de cidadania ao excesso, ao desperdício e ao luxo. Já mesmo Platão se viu obrigado, aquando das suas reflexões sobre a instalação da comunidade ideal, a desistir da hipótese da polis frugal. O mais sábio dos gregos simplesmente não soube responder quando Gláucon, confrontado com a descrição de uma refeição na cidade sem necessidades, retorquiu: «Se tivesses fundado uma cidade para porcos, ó Sócrates, o que é que lhes darias para comer a não ser aquilo que descreveste agora?» Face a esta objeção, Sócrates tem de dar-se por vencido e permitir a conceção de uma cidade de abundância. Analogamente estamos obrigados a tomar em conta, nas nossas estimativas e nos nossos projetos de um mundo futuro, que os homens das nações ricas tomarão a sua prosperidade e as suas premissas tecnológicas por conquistas das quais já não querem abrir mão. Continuarão convencidos de que é a tarefa da evolução globalizar o bem-estar material e os privilégios expressivos que eles próprios gozam, através de um crescimento constante. Irão recusar aceitar a ideia de um futuro que se fundamenta em decrescimento e contenção.

Contra isto, os partidários da nova modéstia retorquiam que os abastados de hoje, mais cedo ou mais tarde, não terão outra opção a não ser acomodar-se aos factos ecológicos. Na medida em que um elevado número de produtores e consumidores se juntará ao clube 
dos esbanjadores, os limites para as emissões e as expressões vão-se fazer sentir mais cedo e de forma mais dramática. E é aqui que entra em jogo o axioma de todos os argumentos acerca dos limites de crescimento: //37 a Terra existe como exemplar único, e mesmo assim as nações ricas vivem como se pudessem explorar uma Terra e meia ou duas Terras. Se o seu estilo de vida fosse extensível a todos os cidadãos do planeta, a humanidade necessitaria nada menos que quatro Terras. Mas visto que a Terra é uma mónada única e não multiplicável, devemos aceitar a primazia do limite em detrimento do impulso do excesso.

À primeira vista, este argumento parece irrefutável. Partindo do princípio que a Terra e a sua biosfera são uma singularidade incapaz de ser aumentada, a civilização moderna da expressão e do conforto não pode deixar de avaliar a atitude explorativa como irracionalidade imperdoável. O tratamento que o homem confere ao seu planeta parece-se, assim, com um filme de catástrofe, onde dois bandos da máfia, a bordo de um avião numa altitude de doze mil metros, se envolvem em combates mortíferos com armas de grande calibre.

Mesmo assim será legítimo perguntar se tirámos da visão monadológica da Terra as consequências corretas e adequadas. Será que entendemos bem a nossa situação quando interpretamos o planeta e a sua biosfera como unidade não multiplicável, e esta como um fixum inultrapassável? Deveríamos ter em conta o seguinte: já não lidamos somente com o originário dado cosmológico Terra e o originário fenómeno evolutivo Vida, pois a estes dois dados básicos juntou-se, no decorrer da evolução social, a tecnosfera, a qual, por seu lado, é incentivada e tutelada por uma noosfera. Estas duas dimensões de acréscimo na mira, é legítimo transpor o dito de Espinosa que ninguém descobriu, até agora, o que o corpo é apto a fazer - relacionado, em Espinosa, com o corpo humano - à própria Terra. Até agora, ninguém descobriu o que o corpo da Terra é apto a fazer. //38 Ainda não sabemos quais os desenvolvimentos que se poderão efetuar se o desenvolvimento da geosfera e biosfera for impulsionado pela inteligência da tecnosfera e da noosfera. Não se pode excluir a priori a hipótese de que este impulso surta efeitos equivalentes a uma multiplicação da Terra.

A tecnologia ainda não teve a sua derradeira palavra. Se perspetivamos a tecnologia, como tem sido hábito até hoje, apenas sob o aspeto da destruição do meio ambiente e da atividade biogénica, então isso mostra apenas que ela está ainda, sob vários aspetos, no seu início. Alguns anos atrás fez-se a proposta de distinguir entre heterotecnologia e homeotecnologia ${ }^{11}$, baseando-se a primeira na violação e no engano da natureza, e a segunda na mimesis da natureza e na continuação de princípios naturais de produção num patamar artificial. Com a modificação da tecnosfera segundo padrões homeotecnológicos e biomiméticos iria surgir, paulatinamente, uma imagem totalmente diferente da interação entre ambiente e tecnologia. Experienciaríamos o que o corpo da Terra é apto a fazer se mudássemos, no nosso lidar com este corpo, da exploração para a cooperação. No caminho da mera exploração, a Terra jamais abandonará o seu papel de mónada limitada. No caminho da coprodução que se dá entre Terra e tecnologia, a Terra poderá tornar-se num planeta híbrido onde se abrirão muito mais possibilidades do que geólogos conservadores estão dispostos a acreditar.

11 O próprio autor, em Nicht gerettet. Versuche nach Heidegger [Ainda não salvos. Esboços na esteira de Heidegger]. Frankfurt/M. 2001, pp. 212s. 
Ideias análogas conceberam as mentes mais criativas do movimento ecológico em todo o mundo. Apresentaram cálculos que mostraram que, a nível mundial, se pode reduzir para metade o consumo de recursos e mesmo assim conseguir duplicar o nível de prosperidade. Na mesma direção vai uma observação excêntrica de Buckminster Fuller que estabelece uma ponte //39 entre a milagrosa multiplicação dos pães no Novo Testamento e a história da tecnologia metafisicamente interpretada: «Ao aplicar a lei da alavanca (...) torna-se literalmente possível (...) conseguir mais ao usar menos. Talvez tenha sido este enriquecimento intelectual (...) que Jesus Cristo queria ensinar no Sermão da Montanha, aquela narrativa enigmática sobre os pães e os peixes.» ${ }^{12} \mathrm{O}$ desfecho do seu Manual de Instruções destina-se por isso a um apelo ao ethos da criatividade:

Portanto, planificadores, arquitetos e engenheiros, tomais a iniciativa! Lançais mãos à obra, e acima de tudo, trabalhais juntos e não escondereis nada, e não tentareis ganhar à custa dos outros. Cada sucesso que não considera isso será efémero, e cada vez mais. São estas as leis de sinergia segundo as quais a evolução se dá e que esta nos quer mostrar. Não são leis feitas pelo homem. São as leis infinitamente generosas da integridade intelectual que governam o universo. ${ }^{13}$

Devemo-nos precaver de reduzir estas enunciações à ingenuidade que certamente está presente nelas. Se a grande autodidática chegasse ao ponto de manter dentro de limites as emissões da ignorância, então isto só aconteceria graças à integridade intelectual de todos os que atualmente assumem a responsabilidade pelo seu saber positivo e pelos seus prognósticos nefastos. //40

\section{§ Uma política para a Terra}

No subtítulo deste ensaio apelidou-se o conceito "Antropoceno" como um "estado" de um processo à margem da história da Terra. Agora tornou-se claro que a expressão "estado" fica, neste contexto, esvaziada por uma ironia radical. A situação antropocénica é, devido à sua lógica apocalíptica (referente à qual o percorrer antecipativo da morte mantém a vinculação com o regresso ao instante presente), o contrário de tudo aquilo que os homens ao longo da história associaram com consagrados conceitos de estado, seja o que for que assim se chama, o Estado, o que está em vigor, "o corporativo e o constante", a instituição ou a "com-posição" ("Ge-stell”). Foi Bruno Latour quem chamou à colação, numa parte incisiva da sua quinta Gifford Lecture, proferida em 2013, que o lendário par de conceitos da autoria de Thomas Hobbes, o "estado de natureza" - state of nature - e a sua superação pelo estado de sociedade, sofreu uma inesperada deslocação do seu sentido: nasceu um novo estado de natureza que nenhum Leviatã será capaz de domesticar. Desencadeou-se uma nova guerra de todos contra todos, cujos protagonistas deixaram de ser meramente lobos e ovelhas, ou seja, povos armados e ideólogos dispostos a matar. Os novos protagonistas que se combatem uns aos outros numa batalha com frentes mal definidas, pertencem a um conjunto de agentes que, junto com as "sociedades" humanas, povoam o campo de batalha e o campo de

${ }^{12}$ Buckminster Fuller, op. cit., p. 51.

${ }^{13}$ Ibid. 
acontecimentos: o $\mathrm{CO}_{2}$, a altura do nível do mar, as algas, os computadores, os micróbios, o atum, os meteoritos, os antibióticos, os algoritmos, o gás metano, os direitos humanos, as turbinas eólicas, o milho geneticamente modificado, o rim transplantado. O ironicamente renovado "estado de natureza" nem é idêntico com o //41 caos da criação nem pode oferecer algo que fosse parecido com o que se associava com o conceito moderno de estado.

Segue daí que a situação antropocénica exige um novo debate sobre a constituição que poderá resultar, na melhor das hipóteses, num processo que implica uma ordem não leviatã ou, dito melhor, numa rede de tais processos. Nesta rede, os órgãos constitucionais e as entidades jurídicas seriam definidas nos moldes de uma relação jurídico-política de uma "cidadania da Terra" ainda por estabelecer; para além disso, também a convocação do coletivo dos cidadãos da Terra enquanto tal deveria realizar-se em moldes novos e sob formatos diversos, aquém e além da Declaração Universal dos Direitos Humanos. É óbvio que estes processos equivalerão a uma titanomaquia. Nesta, os cidadãos da Terra reunir-seiam sob o lema da batalha que o poeta Friedrich Grabbe lançou em 1836: "Já só o desespero nos pode ainda salvar."

Quão desesperado é o clima antropocénico em geral mostra o facto de que alguns dos seus mais importantes comentadores se socorrem de recordações de movimentos de reforma religiosos para incentivar os agentes da civilização hodierna à necessária mudança de atitudes. É nesta linha que se alinhavam, nos anos 70 e 80 do século passado, autores como Ivan Illich, Rudolf Bahro, Hans Jonas, Carl Friedrich von Weizsäcker, René Girard e Carl Amery; mais recentemente, juntaram-se a estes as vozes de Robert N. Bellah, Bruno Latour e do Papa Francisco, entre outros.

A nenhum destes autores se ouviu o tom do desespero tão claro como a Carl Amery, publicista e romancista da ala esquerdista do catolicismo. Amery, um dos fundadores intelectuais do partido dos Verdes na Alemanha, chegou a afastar-se mais tarde deles, //42 desiludido das suas estratégias de adaptação pragmática. Amery promoveu, face ao seu prognóstico de competições de extinção e de guerras de recursos para o século XXI, uma mobilização de forças fundadoras de religiões, numa dimensão que ultrapassaria todas as práticas religiosas até agora conhecidas. Do seu ponto de vista - desenvolvido nomeadamente na obra A mensagem do século. Sobre a vida, a morte e a dignidade, de 1994 -, deveria ser sobretudo a parte da humanidade com um nível de tecnologização elevado a primeira a aprender a superar o pânico biologicamente determinado e terrestre demasiadamente terrestre - da luta pela sobrevivência. Esta parte da humanidade estaria perante a tarefa de criar uma ars moriendi nova e religiosa, querendo isto dizer no sentido do nosso autor: meta-biologicamente fundada, capaz de contribuir para o surgimento de uma atitude que fosse sensível para a distribuição justa de oportunidades de vida entre os povos e as espécies.

Quão desesperadas que pudessem parecer estas observações, a intervenção de Amery elucidou-nos ao menos sobre o seguinte aspeto: a ontologia política da cidadania da Terra traz consigo a exigência de que deva haver uma antropologia política segundo a qual os homens se entendem, como nos tempos da poesia épica e da tragédia ática, do fundo da sua raiz como mortais. O seu ponto de referência já não seria o olimpo habitado por deuses que não se preocupam com o mundo, mas a Terra ela mesma, comum a todos os mortais, com todas as suas regiões diferentes, uma Terra que é demasiado real para desempenhar o papel 
de uma instância transcendental habitual, mas, por outro lado, também demasiado transcendente para se tornar posse de um único poder imperial. Nesta perspetiva, a visão de Hölderlin segundo a qual o homem habita poeticamente a Terra, continua a ser vinculativa. A conceção do Antropoceno contém as minima moralia espontâneas da época presente, pois implica o cuidado para com a coabitação dos cidadãos da Terra, sejam estes humanos ou //43 não humanos. Apela à participação na construção da rede dos círculos de vida simples e complexos, nos quais os agentes do mundo atual geram o seu existir no modo da co-imunidade. 



\section{II}

Textos críticos 



\title{
Traumatology and Technology - On Sloterdijk and Anders
}

\author{
Bernhard Sylla*
}

\section{Introduction}

This paper brings together slightly edited material from previously published articles in which I looked at both Sloterdijk and Anders in direct connection to Heidegger. In those articles I attempted to draw attention to an aspect not only of Heidegger's, Sloterdijk's and Anders's work, but also of the work of authors such as Adorno, Beckett, Derrida, Lacan, and, more recently, Žižek - the aspect of the traumatic. My reflections on the traumatic contained in those articles, tied to Heidegger as they were, were largely concerned with metaphysical or ontological questions. They did not attempt to answer the question of how to establish an ethics of technology. I will now, at the end of this paper, provide some scattered hints on how to address this question in connection with my previous reflections.

\section{What do I mean by Traumatology?}

What should we take the term Traumatology to mean? Given this paper's natural constraints, I must content myself with only a brief outline of my arguments in this regard.

First of all, traumatic experiences have a distinct "logic" or "structure." A first characteristic of these experiences is that they create a tension that is eminently radical namely, the tension between the two farthest existential poles, being and nothingness. A second characteristic, which follows from the initial tension, concerns the problem of immunization, its success or lack thereof and the reasons for either.

On a second level the question arises of what trauma is and under which perspective are we to consider or understand the phenomenon of trauma. The two aspects are linked what we mean by trauma is largely dependent on the perspective from which we consider it. There are three fundamental perspectives or types of perspectives that seem noteworthy to me: the psychological, the sociological and the philosophical. These perspectives often overlap to a lesser or greater extent. The reason for this overlap is that there could hardly be a greater variety of ways in which scholars have understood the concept of trauma. This diversity and heterogeneity of approaches has itself led to the creation of distinct trauma concepts. And these distinct concepts do not map neatly onto the three kinds of perspective. In order to make this introductory caveat clearer, I shall simplify a bit: one can make a rough distinction between an individual trauma, a collective trauma - and here between a

* Centro de Ética, Política e Sociedade, Universidade do Minho, Braga, Portugal. 
collective trauma experienced individually or directly and one experienced only indirectly and a "humanity trauma." ${ }^{1}$ Though it would seem intuitive to link the first form of trauma to psychology, the second to sociology and the third to philosophy, this would be too reductive. Psychology, sociology and philosophy often refer to two or even three of the forms in their analysis.

All three forms of trauma are concerned with the actually experienced or otherwise imagined intrusion of an external, violent power in an entity, resulting in the collapse, either real or imagined, of that entity's immune system. The collapse of this entity's immune system is experienced as a kind of powerlessness, i.e. as a capital inability to safeguard the security, the life and the existence of said entity. As Freud nicely put it, it is an experience similar to the breaking of a dike or a rampart (see Freud 1940a, 27ff.). At the individual level, experiences such as rape, torture, car accidents, etc. can be traumatic. These usually lead to severe dissociation of the personality. As to the collective level, I will limit myself to two hints of possible instances. First, works such as those of Volkan² show that trauma narratives can aid in the creation of collective (cultural, religious, national, etc.) identities, and $a$ fortiori also include a potential for violence by designating a common external enemy, an act intimately connected with the idea of sesecurity and hence connected to the immunity of the group or collective entity. Regarding individually experienced collective traumas, the relevance of two questions was discussed early on, questions which are not unimportant for our purposes. According to Freud's speculations an individually experienced collective trauma had a higher "chance of recovery" when the victim managed to identify with collective ideals or ideals concerning a representative leader figure. This, however, said Freud, often resulted in the removal of ordinary, rationally motivated inhibitions, such as the willingness to commit brutally violent acts (see Freud 1940b). At the philosophical level, it comes down to the question of the "traumaticity" of our "Being." Texts from Adorno, Benjamin, Derrida, Rorty, Heidegger, and, indeed, Sloterdijk and Anders, show that the issue of "traumaticity" in philosophy is virulent.

Were we to limit our philosophical perspective on the phenomenon of trauma to its "metaphysical" or "anthropological" aspects, three aspects would strike me as essential: (i) the pursuit of immunization, of safety for oneself or for another "equivalent" entity. This pursuit presupposes the awareness of something threatening - otherwise the quest for immunization would lack any motivation. It is therefore about Being and Nothingness, or Being and a potential "nihilating" force; (ii) a radical pursuit of immunization contains in itself the moment of violence, which is therefore itself a "nihilating force," oriented however to its very own Being. Herein lies a dilemma that can manifest itself "phenomenologically" in different ways. (iii) The "dialectic" of Being and Nothingness, which in (i) and (ii) manifests itself in a being or entity, may nevertheless expand beyond this entity. This can be conceived in entirely distinct ways depending on the philosopher. For Heidegger it would concern the question of in what way is the traumaticity inherent in the history and logic of Being. For Adorno, traumatical would be the false effort to ignore the negative dialectic inherent in history.

\footnotetext{
${ }^{1}$ For more on the topic, with references to the relevant literature, see Sylla (2015)

${ }^{2}$ See, above all, Volkan (2004).
} 
After these admittedly stenographic preliminary remarks, I would like to go into some further traumatological aspects, such as those discussed in the writings of Sloterdijk and Anders.

\section{Sloterdijk}

\subsection{Some background theses}

In the first volume of his Spheres-trilogy, entitled Bubbles ${ }^{3}$, Sloterdijk develops a philosophical project directly opposed to theories that start from the unreflective primordiality of the "I" as a knowing and sentient subject. This critique bears not only on post-Cartesian philosophy, but in principle on all philosophy, even when the philosophical starting point is not the self, the subject, or even "human beings" as a whole. For Sloterdijk, not only is the "I" a postnatal phenomenon but so are those experiences that in Heidegger are linked with "nothingness." First is the primordially given Being-With (Mitsein), as Being-In (In-Sein) of the fetus in the mother's uterus and as co-dyad (Mit-Dyade) of fetus and placenta - a Being-In (In-Sein), which has first and foremost ("zuerst und zunächst", to use another Heideggerian expression) a spatial quality and a certain subsequent spatial sensitivity that may awaken before any temporal experience is underwent. Nothingness and the I come into the fore only at birth - and so there is here already a first traumatological moment. With birth, the already nine-month old human being is thrown out of the absolutely given Being-In into the outside world. The primordial Being-In, which, according to Sloterdijk, exhibits a tri-partite structure of "Something is with Something in Something," now undergoes the fundamental fragility both of Being-With (Mitsein) and Being-In (Insein). Being-With (Mitsein) loses the character of immediacy and is now mediated, and the "In" loses the character of the "familiar" (Heimliches) and now becomes the "uncanny" (Unheimliches), the monstrous (Ungeheures). It is the first, and indeed the first spatiallysensitive experience of Nothingness. The Being-In, according to Sloterdijk, is now "coupled" to the "outward bound" tension, where "outward" has the connotation of both a spatial and temporal «ecstatic provisional going ahead»: Being-In becomes «the inhabiting in the monstrous.» (Sloterdijk 1998, 643).

The putative Heideggerian objection, that here the approach should be fundamentalontological rather than anthropological, is, according to Sloterdijk, misguided and reveals an unfounded aversion to the intertwining of empirical and anthropological aspects with apparently pure metaphysics or ontology. The Dasein is finite and begins as finite, and its beginning had always been an especially blind spot of "universal and pure" philosophy. If I understand Sloterdijk properly, then it is precisely this factual-empirical finitude which gives us insight into "the metaphysical" in the sense of fundamental Being and Nothingnessstructures (Nichtsstrukturen - may Carnap pardon me for this apparent pseudo-concept), for Sloterdijk calls this spatial and anthropological awareness of the «inhabiting in the monstrous» a «metaphysical premise» (Sloterdijk 2001, 157) of our Dasein.

${ }^{3}$ Sloterdijk (1998); the other volumes in the trilogy are: Sloterdijk (1999) and Sloterdijk (2004). 
As to the identifying and structural marks of the monstrous, there are even more powerful analogies with Heidegger here. For Sloterdijk, the sensibility towards the phenomenon of the monstrous arises first out of the postnatal possibility of the separation between the inner and the outer. The inner corresponds to the postnatal need to provide external uteri, living spaces that serve simultaneously as protected spaces (Schutzzonen), as immunological places. The outer in turn relates to the adversarial, the completely uncontrolled, that which a fortiori can endanger the protected spaces, that which is both universal but also highly vague (it includes all that is outside) and perhaps because of that, fear inducing. As danger, it symbolizes the possibility of the collapse of the protected space, and thus the possibility of my death, of nothingness belonging to me. On the other hand, this is a "general Nothingness" due to its fundamental indeterminacy. In this sense, it corresponds to a certain extent to Heidegger's "Überwältigung." The Heideggerian aspect (here with positive connotations) of violent action (Gewalt-tätigkeit) in turn corresponds to the phenomenon that Sloterdijk, in one of his texts, called the «revolution of beginning oneself (Revolution des Selberanfangens) against the being-already-begun (Angefangensein)» (Sloterdijk 1988, 46). While no "I" activity is yet required in the state of fetal clinging to being-already-begun, it becomes increasingly more so after birth. This revolution, however, and here too there are obvious parallels with Heidegger, is not only a revolution against the being-already-begun in prenatal symbiosis, but also against the postnatal being-already-begun determined by the interpretations of others, particularly those which are linguistically articulated; or in other, Heideggerian words, against the "fallenness" which is simultaneously necessarily existential. On the other hand, as in Heidegger, this violent action is also coupled with the desire, the "metaphysical urge" to be at home everywhere, as Heidegger put it (Heidegger 1976, 118). Sloterdijk's entire Spheres project outlines a story of the desire to build protected spaces, second uteri - and here the dimension of the temporal enters significantly into the foreground -, a history of homeconquests (Heim-Eroberungen) which could be understood as Sloterdijk's version of the 'History of Metaphysics.' Viewed from a structural perspective, metaphysics begins with the prenatal Being-With (Mitsein), then finds a new foundation in the anthropological and biological conditions of the so-called neoteny (see Sloterdijk 2001, 188ff.; 2004, 756ff.), according to which man, from a philo- and ontogenetic perspective, is/was not exposed to permanent developmental pressures due to social protected spaces. And so he could develop into a luxurious Being, whereby he would acquire the ability to creatively design new protected spaces, new forms of "inhabiting" (Wohnen). Further milestones (Wegmarken) on the historical road are given by the protection spaces conceived by traditional metaphysical and religious thought, which represent a boost toward generality and universality and which will be replaced by the dissociated "foam forms" of inhabiting, the protection spaces in the present. Sloterdijk's book You Must Change Your Life: On Anthropotechnics (Sloterdijk 2012) can be read from an historical perspective as an advanced analysis of the intensive training attempts that have been made to build stable immune spaces with controlled external interactions.

Like in Heidegger, Sloterdijk's use of the term "metaphysics" is ambiguous. On the one hand, as already said, it is concerned with the anthropological onto- and phylogenesis of the "metaphysical premise," the "inhabiting in the monstrous," the spatial Being-In of Man, 
whose structure undergoes an historical development. Any insight in this context would be cataloged under "positive" metaphysics. On the other hand, Sloterdijk also uses the term "metaphysics" in a pejorative sense, namely the sense which denotes the now expiring, defeated historical stage of the "inhabiting of the monstrous," namely the phase in which one desperately tries to maintain religious-metaphysical constructions, dogmas and ideologies in order to hold on to the possibility of establishing global, universal protection. ${ }^{4}$ According to Sloterdijk, Heidegger and others, "metaphysical" in the negative sense is predicated of all the thinkers who have not yet rid themselves of this paradigm. Here the relationship with and stance towards technological phenomena also comes into play. Heidegger's technophobia is a kind of understandable defense against a metaphysical transformation (Wandlung) that already has taken place. It perhorresces the loss of self, the loss of the old humanism, the objectification of the subject, but it does not understand that the challenge of man is precisely the new marriage with technology. ${ }^{5}$ This "anti-technological hysteria" (Technikhysterie) is, according to Sloterdijk, a decadent product of a false metaphysical defensiveness. ${ }^{6}$

\subsection{Traumatological aspects in Sloterdijk}

Sloterdijk's traumatology has a clearly anthropological character, though one should add that Sloterdijk's anthropology is certainly bound up with ontological and metaphysicalcosmological claims, though not, as we have already mentioned above, in Heidegger's sense, since Heidegger was indeed counted among those in the class of the "last metaphysicians." According to Sloterdijk, the real drama of traumatological struggle between Being and Nothingness reveals itself phenomenologically in the history of the human "inhabiting" in the monstrous, and this history is that of the rise of the technological. Much of the focus of Sloterdijk's work, especially in the Spheres, as well as in You Must Change Your Life: About Anthropotechnics, is devoted to the "intermonadic" (intermonadischen) conflicts between competing quests for and competing systems of immunization. Behind the latter lies what could be described as "the history of metaphysics," provided one were to extend the precision and scope of the Heideggerian concept. And this history is again highly traumatological. This is because the collapse of certain epochal forms of searching for immunization is always a traumatic experience.

In an essay entitled "Offence by Machines" (Sloterdijk 2001, 338-366), Sloterdijk explicitly returns to the concept of trauma. Offences (Kränkungen), says Sloterdijk, are challenges (Herausforderungen) to the immune system. Offences need not be traumatic, but they can be. This happens when the offence is not really overcome or when, though one knows better, one employs outdated immunization strategies to deal with it. The issue raised in this text is that of "the offences against mankind." In other words, we are, so to speak, positioning ourselves in the field of the history of metaphysics. In addition to the offences detected by Freud, who saw the three major offences against mankind in the history of science as that which Copernicus inflicted on cosmological narcissism, the one Darwin

\footnotetext{
${ }^{4}$ Sloterdijk (1999), see also Sloterdijk $(2004,868)$, where Sloterdijk provides a brief description of the different phases outlined here.

${ }^{5}$ See Sloterdijk (2001, 222ff.).

${ }^{6}$ On Heidegger as the last philosopher of the "metaphysical" epoch, see also Sloterdijk (2004, 24f. and 515f.).
} 
inflicted on human narcissism, and that which Freud himself inflicted on narcissistic reasoning via his psychoanalysis, one must, according to Sloterdijk, add a number of other dramatic offences which he lists as either having already occurred or as occurring in the foreseeable future. I cite here only the last three which, according to Sloterdijk, are bound to be of great concern in the near future: the computer offence, where the "mechanical" double embarrasses human beings due to its higher intellectual capacity; the environmental offence, where the nature of man's incapacity is revealed; and the offence caused by robotics, genetics and bionics, where «the most intimate egological manifestations of human existence such as creativity, love and free will perish like will-o'-the-wisps scattered across a swamp of reflexive technologies, therapies and power games» (ibid., 345). From this gloomy and, looking ahead to Blumenberg, techno-demonizing panorama full of present and future offences, Sloterdijk derives the conclusion that man or the Being of man can also be understood as a traumatological cogito: «I am offended, therefore I am» (ibid., 351).

Turning now to Sloterdijk's account of the traumatological structure of the history of metaphysics, I believe one can detect a kind of duplicitous or double discourse. The first discourse distances itself strongly from Heidegger and seems to hold a position diametrically opposed to him. According to him, it is wrong and therefore traumatic, to hold on to old, outdated strategies to combat trauma. Instead of clinging to infantile or religious forms of "primary narcissism," man must ascend to the developed forms of "able narcissism" (Könnensnarzißmus) (ibid., 346). This is also the point at which the concepts of "technology" and "metaphysics" short-circuit. A backward, erroneous defensiveness against offences is, according to Sloterdijk, "reactionary," leads to technophobia, yet the demonization of technology falling out of an «already robust metaphysical transformation» is a «decadent product» of an outdated «metaphysical defensiveness» (ibid., 223). On the contrary, what is necessary is a fundamental acceptance of technology. This relies on an ever more globalizing networking of living spaces and living forms and their increasing virtualization (ibid., 131-135). More importantly, however, is that in the new "foam-form" of inhabiting the dream of inner and outer immunological control becomes technically feasible. But this in turn is connected to the most radical metaphysical change, namely that which, according to Sloterdijk, man must become acquainted with: the fact that technology engages with the "metaphysical," "formerly apparently autonomous field» of the subject's constitution (ibid., 220f.). In contrast, it is understandable that the old metaphysical paradigms in a somehow paralyzed manner experience this metaphysical transformation as loss of self, as a loss of the old humanism, as the objectification of the subject (ibid., 222f.). The thesis, that man must confront himself with this new challenge, which should however be accompanied by a changing understanding of technology - rather than the old understanding of technology as domineering, technology must be conceptualized as homeotechnology - has, as is known, since 1999 given rise to the most violent polemical debates. Seen through an Heideggerian perspective, one could characterize this discourse so that here the loss of the essence of man is accepted voluntarily and the forgetfulness of being (Seinsvergessenheit) is complete. From Sloterdijk's perspective, however, the difference between beings and Being is different. If it exists at all, it is that there are certain epochal ("metaphysical") "modes of being" (Wesensweisen) of the traumatologically founded BeingIn of man, whose development leads to a new essential mode of being with a new 
immunological concept of Being-In. The age of technology is distinguished from the preceding, "metaphysical" (understood in the pejorative sense) age by the fact that Being-In concepts ("Inhabiting-projects") are increasingly dissociated and de-ideologized, leading, in the long run, to a challenge to the "essentializing" (Wesen) (verbally understood) of the Dasein itself. But that in turn can be understood as a change in the mode of being (Seinswandel), both of "Being" (Sein) as well as existence (Dasein), whose task becomes to deal with the most extreme forms of its self-production and the phenomenon of death. Sloterdijk's look into the future can therefore be interpreted as an insight into the nature of this venture, which one, despite a sometimes naive optimism, cannot charge with lacking a sense of the perversity, abysses and dangers that are contained in this challenge. ${ }^{7}$ By contrast, Heidegger commits the old Hegelian mistake of seeing his own time as the end time, as the climax of historical development. Because of the forgetfulness of Being is total, there is no longer any development, but only an either-or. And so too the counterpart of the forgetfulness of Being, the rescue of Being (Seinsrettung), acquires a character of finality. Should the humans succeed, one would have to imagine the world as a scenario of ecumenical serenity, a kind of union of spectacle of nature and artistic world in which everyone cooperates peacefully and inspirationally in the development of one's authenticity and that of others, be it things or people.

This "charge" of an unreflective and thus dangerously naive dichotomy - inscribed in the back of each traumatology - is precisely one that Sloterdijk too can raise. In a long paragraph of the introduction to "Domestication of Being" (ibid., 145-154), Sloterdijk proposes a brief diagnosis of the philosophy of the 20th century, which started as an attempt to escape a false mediocrity, which continued after the experience of the negative radicalism of the Second World War, at least in the minds of those which understood themselves as avant-garde (here Sartre's appeal to a "literature of extreme situations" is mentioned, as well as existentialism in general, but also the neo-Marxist left). Instead, it was necessary to free themselves from this obstinate adherence to radicalism. Radicalism leads to hyper-morality, which in turn evokes phenomena of anti-hypermorality. On the other hand, the deradicalization understood by postmodernism (global networking, disempowerment of the aggressor mentality) brings with it the risk of a new mediocratization. Given the new developments, that the organ for reception of the radical modernism of the 20th century had become virtually deaf and that no real platform was given for their adequate renovation, a new tendency to mediocrity arose which runs the risk of treating everything according to the norms of the academic routine (academic autism). And sight of the fact was lost, especially after the apparent defusing of the nuclear bomb threat, the East-West arms race, etc., that the monstrous is still among us. That is precisely the point I want to emphasize here: the traumatology also overtakes Sloterdijk. The primal fear of total nothingness, which was seemingly easily ousted by introducing the magical term "homeotechnology", now rears its head again. And as with Heidegger it is the blindness of their radicalism and of the latent danger due to the false sense of security in an environment of thorough mediocrity that can be most dangerous. Sloterdijk's catalogue of current monstrosities has different versions. In

\footnotetext{
7 The list of publications in the polemical German debate about Sloterdijk's technophilia is already very long and does not need to be mentioned here. Of some special interest, however, is the contribution of Félix Duque (Duque 2002), since it presents an intense contrastive analysis of Sloterdijk and Heidegger. Duque is one of the numerous proponents of the opinion that Sloterdijk's understanding of technology is quite dangerous.
} 
the paragraph mentioned above he identifies three scenarios: were the global networks to collapse, the fall would be steep; the new biological nuclear technology could make all of humanity its hostage; the primacy of the economic over the political could trigger a new counter-revolution of the political. Approximately a decade later, Sloterdijk resumes the criticism already begun in Eurotaoism - Sketch for the Project of a Critique of Political Kinetics (Sloterdijk 1989) against the destruction of the environment, now to warn against the "big disaster" (Sloterdijk 2012, 702) and to do so prior to any availability of technical means to avoid it, prior to the withdrawal of the "Being-base" for all other Being-Indevelopments, i.e. before all life and Being on this planet is destroyed once and for all. And so, I think, we can easily find in Sloterdijk a sort of blending of two aspects, the same aspects that some decades before had been disavowed by Blumenberg as a consequence of demonizing forms of argument: first the aspect charged with manic-depressive undertones, a black and white drawing of conjured danger and, second, the naïve, speculative or even megalomaniac belief that we will be able to deal with this danger without any further accommodations. As far as I can see, this diagnosis still stands even when considering Sloterdijk's 2016 article, translated in this volume, entitled "Das Anthropozän - Ein ProzeßZustand am Rande der Erd-Geschichte?" ("The Anthropocene: A Process-State at the Edge of Geohistory?"). Building on an on-going debate, begun 15 years ago, about the legitimacy of the term "Anthropocene" in philosophical and cultural discourse, Sloterdijk characterizes the contemporary scene as one governed by an "apocalyptic logic" (Sloterdijk 2016, 20), the latter caused in part by a "kinetic expressionism" (ibid., 15) - a concept clearly taken from the theses of the Eurotaoist book -, a logic consisting in self-reinforcing acceleration processes that lead to a self-destructive collapse. Or, in other words, that lead to a state of all or nothing, one in which we can hardly hope to answer adequately the challenges of life and death given the status quo of an ignorant managerial class both in the political and the scientific establishment. All the essential traumatological elements are here easily identifiable. Sloterdijk's response can be read as a variation on the responses given in earlier works. Sloterdijk's hope hinges on a new view of technology already denoted by the term homeotechnics, one which does not want to rape or conquer nature, but rather one that wishes to make use of the potentialities of Nature actualized through biomimetic methods at the artificial level. This harmless sounding program is of course not without its dangers, for without an account of its actual content, this program could be used for evil just as much as for good. The fact that applied homeotechnics promises a more effective (because relying on co-operation between human beings and between human beings and nature) immunity, a new "co-immunity" (ibid., 43), shows again, in conclusion, how strongly the logic of trauma informs even the aforementioned article.

\section{Günther Anders}

I now want to show how distinctive features of the traumatological can also be found in the work of Anders.

\subsection{Some background theses}


At first glance, Anders's thought seems to concern itself obsessively with a single theme - that man has become capable of generating the means by which he attains the absolute power to definitively and irreversibly annihilate all of mankind. To have the knowhow to generate such means is all it takes for the threat of definitive death to hover over mankind. This is the idea at the core of a simple and self-evident traumatology, which consists simply in man's powerlessness in the face of this threat. But Anders's philosophy goes farther, and it is that I now wish to develop.

The powerlessness of man at this first ontic level seems exceedingly obvious. Even so it has eluded man's understanding, due, in the first instance, to a phenomenon which Anders calls the promethean discrepancy (Anders 1988, 267ff.). The promethean discrepancy consists in the wide, disproportionate gulf between kinds of abilities: we are able, as homines fabri, of making something whose effects and whose essence we can neither adequately feel nor adequately represent. We are therefore not in a position to be able to relate ethically and morally with the product of our making. For this reason, contemporary man lives, according to Anders, in a permanent schizophrenic state. He makes something which he can no longer affectively understand or even adequately represent. This discrepancy between distinct human faculties is therefore increasing. While the ability to make and produce may grow without limit, our emotional and representational faculties cannot. Hence the gulf between our different faculties is increasingly and irreversibly widened.

Anders does not restrict himself to the ontic threat of man's annihilation posed by the atomic bomb. Behind this threat there is another, less obvious, more hidden, and if we were to use the old distinction between essence and existence, we would call it a threat to the essence of man. This threat is tied to a human behavior, which, Heideggerianly speaking, happens in the realm of Man. In the first volume of Die Antiquiertheit des Menschen, in a separate chapter, Anders addresses the so-called promethean shame (Anders 1992, 21-95). This shame resides, once again, in a profound discrepancy, that is, in a disproportion. In the face of the increasing perfection of his products, man feels something like an inferiority complex. He measures himself with the measure of his increasingly more powerful and perfect products, which instills in him the feeling of not being able to compete with them. Consequently, he feels shame for his physical, psychic and intellectual human condition, shame for not being a being who was made but merely one who was born. One way of fighting this shame is to idealize the unattainable: man wants to become like his machines, and if he is unable to do so, he wants at least to be able to create the false appearance of being just as perfect as his products. Anders believes this phenomenon can be identified in a variety of day-to-day domains such as the practice of putting on makeup, our reaction to automated labor, the obsessive concern with photography and other modes of representation, etc.

The wish to become the same as one's products has been interiorized in the behavior of the modern man to such an extent that not only does he not understand what is happening, he does not even want to be confronted with the suspicion that it may be happening. On the contrary, he invests all his energy, all his resolve, in order to attain the unattainable ideal. The respective approaches to this phenomenon reveal some parallels 
with those of Sloterdijk regarding the anthropotechnical exercises, and may in fact have influenced Sloterdijk directly, since Sloterdijk explicitly refers to Anders's work. ${ }^{8}$ Anders uses the term Human Engineering to denote these exercises, which appear innocuous and are socially valued. What in fact happens is that these exercises lead to the emptying of man's being, precisely because it puts into practice the leveling of man and machine. This will lead directly and inevitably to the technologically planned production of man himself, which, according to Anders, is already taking place (Anders 1988, 20).

The integration of man and machine, which leads to the replacement of man with machines, reveals itself, according to Anders, at a variety of levels, of which I will name but a few.

The foundations of ethics, politics, economics, etc., are, according to Anders, sabotaged and corrupted by the logic of the superiority of the technical device. Technical devices are the ones which makes demands to man. It is they that ask what man has to offer so that they can show and fulfill all their potential, the full spectrum of their features. When economic or political decisions must be made, either at the national or the international level, one cannot trust the limited capacities of man. Rather, one ought to delegate major decisions to the calculus of data processing devices. To trust man with the decision of when to launch nuclear weapons is highly risky, and already in the last century, such decisions were largely delegated to computer programs. In what concerns consumerism, Anders stresses, as does Heidegger, that it is the products themselves that demand an attitude of fast consumption, an attitude of Schonungslosigkeit, i.e. of deliberate carelessness. To preserve, fix and repair devices and things is more expensive than simply throwing them away and buying newer models.

\subsection{Traumatological aspects in Anders}

Behind this phenomenology of carelessness and the gulf between man and the technical device, something else is hiding, and this something else leads me once again to the logic of trauma. I shall focus on four fundamental aspects through which this traumatology is made manifest.

(i) Man strives to overcome clearly serious and existential threats yet, by doing it, he cooperates with his own annihilation. This concerns not only nuclear weapons and the ontic survival of man, but, at bottom, it concerns his essence.

The wanting-to-be-like-machines reveals a lack of measure from several perspectives: it is a false Anmaßung, a superbia (arrogance) or false presumption which longs for its own perfection, in turn caused by a false Anmessung, a false integration which takes as its standard the logic of the product, of that which is technically achievable. In a hidden dialectic, the longed for perfection reveals itself as a self-inflicted humiliation

\footnotetext{
${ }^{8}$ E.g., in "Die Domestikation des Seins" (Sloterdijk 2001, 208), where already appears the core idea of anthropotechnics largely developed only later in Sloterdijk (2012).
} 
resulting in extinction. This extinction is of a new, unheard sort, far graver than any suicide or fatality. The exact interchangeability which exists in the realm of products - which man envies, experiencing his own "uniqueness" as a flaw - encloses in itself the idea of the overcoming of natural "death," and hence the overcoming of an existential necessity, possibility and "capacity" of the human being. Not knowing and not being able to die, in the sense also delineated by Heidegger, happens when the phenomenon of death is no longer among the realm of the possible; in other words, when it's modality, in its threefold Kantian sense, seems to be delegated, indelibly, to the arbitrary deliberation of the "new" man. And hence, not only to Heidegger but also to Anders, man's overcoming of death leads to the death of the essence of the human species (Anders 1988, 47-56) and, consequently, to the death of the human species as such.

\section{(ii) The almost complete ignorance of these events.}

Like Heidegger, Anders too believes there is a tremendous lack of awareness concerning the growing emptying of the being of man. According to Anders, we have lost the capacity to be afraid, and, more fundamentally, the capacity to feel anguish. The absence of anguish is related to the inability to keep up affectively with the world of fabricated devices; this lack acquires dimensions never before imaginable the more the emptying of the human being advances. According to Anders, nihilism has entered a new stage. It is no longer either apocalyptic or suicidal but rather, as Samuel Beckett has brilliantly shown, a nihilism which is itself unable to be a nihilism. ${ }^{9}$ It is a state in which man, in his profound feeling of meaninglessness, has become incapable of feeling either fear or boredom. Whenever man still shows residual signs of his proper nature, when, for instance, he feels a strong rebellious impulse of rage against the machines or against the conditions of labor, he does not usually unleash this rage directly upon those who cause it. Rather he throws himself into those other machines or socio-technological offerings conceived for that purpose - video games, arcades, etc. - or he mutilates himself so to obtain proof of his own flesh and blood existence. ${ }^{10}$

(iii) Man's inability to face this death threat is part of his nature. To fight this inability is an enterprise doomed to fail, for it itselfleads even more surely to death.

Promethean shame is not a shame felt by this or that individual. It is the shame of humanity, that is, of man as such. Just as the child that hides behind her mother once visitors arrive feels simultaneously embarrassed and afraid of being exposed to the world as an individual, of not being able to hide in the being-with-others, promethean shame is the embarrassment and fear of not being able to do anything against the fact of not being a nonI. Freud called the longing to be freed from the ego the death drive; nevertheless, unlike Anders, he did not connect this drive with the longing to become a device.

${ }^{9}$ In this regard, see the text "Sein ohne Zeit. Zu Becketts Stück < En attendant Godot>” (Anders 1988, 213-231).

${ }^{10}$ Slavoj Žižek presents a nearly identical account of the nature of selfmutilation, cf. Žižek / Daly (2006, 147). 
(iv) Escaping into the everyday worsens our ignorance.

Here Anders's reflections come very close to Heidegger's. The escape or flight into the everyday, the day-to-day humdrum and the ordinary, the perfect adaptation to the common opinions and stereotyped behaviors, all those worsen one's ignorance of traumatology. One of the traumatological structures related to the everyday is the irresolvable aporia in which products ask of us the impossible: either, following the stream of dominant opinion, we give in to its demands, which, however, results in our long term extinction as human beings; or we do not give in, but then we are reduced to nothing, to a destroyed entity, undeserving of either self-esteem or that of others. The vague feeling of not being able to deal with this situation, of being its hostage, is traumatic (Anders 1988, 44). The perspective of those who criticize consumerism, the doctrines of the necessity of progress and the marvelous advances of medicine, is wide and well known. Anders believes, however, that there is a growing tendency of immunization against these disquieting critiques. Those voices which alert us to the growing loss of reality due to the growing immersion in a world of technological devices and their demands are often ridiculed (Anders 1992, 44). Perhaps particular to Anders is his stress on the "tabooization" and punishment of this critique. Even in those cases in which this critique is accepted and seriously considered, the assumption is that all we need to address it is to employ technological or politically controllable measures. A discussion that would get to the heart of the matter is still, according to Anders, either forbidden or simply mocked.

\section{Final Remarks}

How can these reflections be linked to our concern about liquid technoethics?

One could first establish a kind of commonality between Sloterdijk and Anders. Any general ethics, and in particular an ethics of technology, falls short if it does not see that it is a kind of theoretical reflection dominated by a sub-conscious pursuit of immunization or perfection, which is suicidal in the final analysis, or, as Derrida would say, which unconsciously follows an auto-immunizing tendency. A higher ethics is first an ethics of technology because the pursuit of immunization or perfection is linked to technical perfecting in a fundamental way. On the other hand, this higher ethics is also liquid, namely because it cannot fundamentally find a firm. Their efforts, both Anders's and Sloterdijk's, are nothing but again the self-preservation of the human species, even though they are done at an allegedly reflective level. Anders provides us with an ethical recipe for this target: the observance of new categorical imperatives, which are nevertheless merely necessary propaedeutic workouts, in form of aesthetic and gymnastic exercises designed to expand our emotional and representational capacities. ${ }^{11}$ For Sloterdijk, the term homeotecnology is strongly underdetermined and looks more like a pipe dream. Both in Anders and Sloterdijk one also misses that the risk of suicidal overreaction is taken into account by the somewhat naïve "meta"-solutions. From the perspective of Adorno, one could argue that these negative

\footnotetext{
${ }^{11}$ By way of example, see Anders (1988, 308-313), where he deliberately employs sports vocabulary, transposing it to the realm of the arts, which he takes to be the last domain in which the growing emptying of the human being may yet be stopped.
} 
dialectics has not yet been taken to its logical conclusion. Another type of general objection would be to unmask the dramatic dichotomy of Being and Nothingness, which underlies the concept of trauma - a position that can be attributed to Blumenberg. There is much more to be said about this - a task I would like to carry out in another paper.

Translated by Luís Manuel Pinto de Sá

\section{References}

Anders, G. (1988). Die Antiquiertheit des Menschen. Vol. 1: Über die Seele im Zeitalter der zweiten technischen Revolution (7th ed.). München: Beck

Anders, G. (1992). Die Antiquiertheit des Menschen. Vol. 2: Über die Zerstörung des Lebens im Zeitalter der dritten industriellen Revolution (4th ed.). München: Beck

Duque, F. (2002). En torno al humanismo. Madrid: Tecnos

Freud, S. (1940a). Jenseits des Lustprinzips. In Idem, Gesammelte Werke. Chronologisch geordnet. Bd. 13 (pp. 1-69). Ed. by Marie Bonaparte with the cooperation of Anna Freud. London: Imago

Freud, S. (1940b). Massenpsychologie und Ich-Analyse. In Idem, Gesammelte Werke. Chronologisch geordnet. Vol. 13 (pp. 73-161). Ed. by Marie Bonaparte with the cooperation of Anna Freud. London: Imago

Heidegger, M. (1976). Wegmarken. Ed. by Friedrich-Wilhelm von Herrmann. Frankfurt/M.: Klostermann [GA 9]

Sloterdijk, P. (1988). Zur Welt kommen - Zur Sprache kommen. Frankfurter Vorlesungen. Frankfurt/M.: Suhrkamp

Sloterdijk, P. (1989). Eurotaoismus - Zur Kritik der politischen Kinetik. Frankfurt/M.: Suhrkamp

Sloterdijk, P. (1998). Sphären I - Blasen. Frankfurt/M.: Suhrkamp

Sloterdijk, P. (1999). Sphären II - Globen. Frankfurt/M.: Suhrkamp

Sloterdijk, P. (2001). Nicht gerettet. Versuche nach Heidegger. Frankfurt/M.: Suhrkamp

Sloterdijk, P. (2004). Sphären III - Schäume. Frankfurt/M.: Suhrkamp

Sloterdijk, P. (2012). Du mußt dein Leben ändern. Über Anthropotechnik. Frankfurt/M.: Suhrkamp.

Sloterdijk, P. (2016). Das Anthropozän - Ein Prozeß-Zustand am Rande der ErdGeschichte?, in Idem, Was geschah im 20. Jahrhundert? (pp. 7-43). Frankfurt/Main: Suhrkamp.

Sylla, B. (2015). Trauma coletivo - notas sobre um conceito disperso. In Ana Gabriela Macedo, Carlos Mendes de Sousa \& Vítor Moura (orgs.), Conflito e Trauma (pp. 461-476). Vila Nova de Famalicão: Húmus 
Volkan, V. (2004). Chosen trauma, the political ideology of entitlement and violence. Available online at <http://www.vamikvolkan.com/Chosen-Trauma,-the-PoliticalIdeology-of-Entitlement-and-Violence.php> [Last accessed: 23. 1. 2015]

Žižek, S. / Daly, G. (2006). Arriscar o impossível. Conversas com Žižek (transl. Vera Ribeiro). São Paulo: Martins Fontes. 


\section{Connecting the dots: History, Technology and Work in Günther Anders`The Obsolescence of Man II}

João Ribeiro Mendes*

1. The title briefly explained.

\subsection{Dots $=$ concepts.}

Common reference works - such as the widely used Oxford English Dictionary and Merriam-Webster - have collected two most frequent uses for the word "dot": (a) first (in grammar, orthography): a small rounded mark used to indicate the end of a declarative sentence (or in oral speech a pause); (b) second (in mathematics, geometry): also a small rounded mark, but used to indicate a location in space. In those same reference works we can learn that the words "dot" and "point" are synonymous and can be used interchangeably. Some suggest the first (dot) is favoured in American English and the second (point) is preferred in British English.

We do not have that semantic doublet in most of the languages. Nevertheless, it could be claimed that both words maintain between each other a sort of an ontophenomenological relationship. If a "point" is a kind of negative concept - as either its etymology ("punctum" in Latin refers to a small hole made by a pointed instrument) and its mathematical typical definition (a dimensionless entity whose locus has to be described as "a place where two lines meet" or are only identifiable by an ordered pair of coordinates) ${ }^{12}$ both indicate - then its supposed counterpart has to be a "dot", a visible mark that brings it forth and positively reveals it. Therefore, although a point tends to remain by its very nature not ostensive, it works as an ontological condition for a dot to come up and, inversely, though a dot is just an effect, it works as a phenomenological condition for a point to become known.

In this article, however, "dots" are to be understood in a more metaphorical sense, i.e., as selected (dense and interweaved) concepts (or focal points) on Günther Anders philosophical landscape (or intellectual quilt).

1.2. Connecting the dots $=$ interpretation(s).

* Centro de Ética, Política e Sociedade, Universidade do Minho, Braga, Portugal.

12 Contrary to what Euclides have claimed, "point" is not a primitive notion, one that does not require explanation and may work as basis for complex geometrical objects such as lines. 
"Connecting the dots", on the other hand, is a rather well known Anglophone idiomatic expression. A more literal meaning can be attributed to it: a sort of puzzle-solving activity usually carried out by children in which, after a series of dots on a paper have been connected in a specific order, lines are drawn to join them, and a picture can be seen. By extension it can also receive some more figurative meanings, as for instance: (a) the intellectual ability to draw a rather obvious conclusion from something relatively evident; (b) the cognitive process through which different ideas are interrelated to arrive at a comprehensive or holistic understanding - a "big picture" - of a complex challenging issue.

It is not only the dots that have a sort of ontological primacy. A supposed picture, artfully arranged, also pre-exists in a latent mode. They are both already there waiting to the puzzle solvers or the interpreters to make the connections to reveal them as such.

We cannot prevent, of course, the puzzle solvers or the interpreters from making totally wrong connections, perchance by accident, nor is desirable preclude them from connecting the dots in any reasonable way they intend. That is precisely the prolificacy of the metaphors here invoked: to suggest or even to induce alternative modes to mesh (the same) concepts, different legitimate interpretations to organize them or make them creatively intelligible.

The metaphor "connecting the dots", therefore, builds upon the "dots" as metaphor. In other words: I will try to show in the following that three specific concepts - Technology (Technik), Work (Arbeit) and History (Geschichte) - particularly explored by Günther Anders in his The Obsolescence of Man $I I^{13}$ are closely linked and offer an interpretation that will allow us to have a reliable picture of our anthropological condition in the present; that same interpretation could also be used as guide for us to devise what to expect in the decades to come.

Briefly explained the title and the general aims of this article, in the following I will attempt: (a) an analysis of the referred selected concepts (or focal points); (b) an interpretation on how they are connected; (c) a discerning of some major consequences for our near future that can be withdrawn from them.

\section{Analytics of the concepts.}

\subsection{Technology: how it became totalitarian?}

I believe it will be correct to say that Anders chief thesis is this: Technology underwent such a remarkable qualitative change after the Second World War to the point of having rendered man obsolete in his faculties and unbefitting for his world - the so-called "Promethean gap" 14 or "Promethean shame"15 explored by the author in the first chapter of the first volume of The Obsolescence of Man ${ }^{16}$.

\footnotetext{
${ }^{13}$ I will translate Antiquiertheit (that who has the property of being old or antique) not by "Outdateness" (being out of fashion or out of time), as sometimes is found, but by "Obsolescence", i.e., not something in disuse or lapsed, but something that can no longer be.

${ }_{14} \mathrm{~A}$ discrepancy between the capacities humans have for innovation and creation and for foreseeing its moral consequences, in which the later outpaces the former.

15 The feeling of insufficiency that derives from the awareness of the referred "discrepancy" or "gap".

${ }^{16}$ Although I use here the word "Technology" to translate "(Die) Technik" (in the original) I am aware of the risks of doing that because

"Technik" (as the French equivalent "Technique"), more commonly used in German (and French) studies is more generic or has a broader
} 
According to Anders this transformation of the nature of Technology, a modification of its essence, didn 't happen suddenly but as a result of a relatively long process. He described it in the introductory part he wrote to the second volume of his The Obsolescence of Man as a process having undergone three distinct phases corresponding to three industrial revolutions.

The first industrial revolution started with the appearance of the machine, or, better, with the iteration of the principle of the "machinic", that is, the possibility of producing machines exclusively through mechanical means; in Anders words: «(..) you can speak of a real "industrial revolution", that is, the first industrial revolution, only at the moment when the principle of "machinery" began to be iterated; that is, by producing machines, or at least parts of machines, by way of machines» (15) ${ }^{17}$.

That revolution, as often said, had its beginning in Europe around the middle of the 18th century. It has generated three new possibilities evolving ever more effective and efficient since then: (a) a constantly larger and more diverse repertoire of tasks previously done by humans being replaced by machines; (b) the increasing automation (work out without human intervention) of the processes of production; (c) and the unbridled exploitation of natural resources necessary to feed the machines.

Mechanization, automation and more recently robotization (tasks and processes being carried out by machines with artificial intelligence and mechanisms of self-control, learning and self-enhancement) may be said to represent three internal moments of that first industrial revolution.

The most distinctive feature of that revolution, as Anders insightfully discerned, is to have made coeval the replacement of instrument by machines and the beginning of human obsolescence, or, in other words, to have left the human being nolens volens irrevocably at the mercy of external forces. In fact, the instruments, although conceived as extensions of human faculties, remain dependent on human will, under its power and usage control. The machines, however, are provided with some degree of autonomy (i.e., do not depend on human agency) to function and infinitely expand, or, in other words, to produce not only products for consumption, but mostly means of production that, regardless of their purpose, are used primarily to keep the production going on. «It is not legitimate to claim with regard to these final products that they are exclusively products and not also means of production", says Anders, «since these final products, for their part - the iteration does not undergo any interruption at all - by being used, produce something, that is: situations in which the production - again via machines - of subsequent products is required.» (15-16)18

At a given time, supposedly, man `s participation in this process started being discarded and ultimately reduced to happen only at its beginning as a manual worker or/and at its end as a consumer. In turn, we may say that that process evolved as if it was driven by an immanent logic of boundless self-maintenance and ceaseless iteration.

meaning than the Anglo-Saxon “Technology”, which (to make short a long story) is much more specific and refers only to more advanced stages of modern devices or machines.

17 «(...) Von einer wirklichen "industriellen Revolution”, also von der ersten, kann erst in demjenigen Augenblick gesprochen werden, in dem man damit begann, das Prinzip des Maschinellen zu iterieren, das heißt: Maschinen, oder mindestens Maschinenteile, maschinell herzustellen.». Page numbers refer to the German edition.

18 «Aber selbst von diesen Finalprodukten zu behaupten, daß sie ausschließlich Produkte, keine Produktionsmittel seien, ist unerlaubt. Denn auch diese letzten sollen ja - die Iteration kennt keine Unterbrechung- durch ihr Verbrauchtwerden wiederum etwas produzieren: nämlich Situationen, in denen eine, wiederum maschinelle, Erzeugung weiterer Produkte erforderlich wird.». 
That allows us to move to Anders ' second chief thesis regarding Technology. He enunciated it, very clearly, in the footnote (nr. 2, p. 439) hereinafter reproduced:

I advocate the thesis which holds that the tendency towards totalitarianism is part of the essence of the machine, and originally proceeded from the realm of technology; that the tendency, inherent to every machine as such, to subjugate the world, to parasitically seize upon the fragments that have not yet been subjugated, to merge with other machines and to operate with them as pieces of a single, total machine: I maintain that this tendency represents the fundamental fact (...).19

The "fundamental fact" is the twofold tendency of the machines, i.e., their inner technical omnivorous and domineering logic, to depredate the world and to place everything and everybody under their dependency. Some, of course, remain sceptical about its veracity, about the factualness that Technology has consummated in contemporary age its totalitarian vocation. It was thinking of them that Anders recalled in the first paragraph of chapter 7 ("The obsolescence of machines", 1969) of The Obsolescence of Man II the power outage that occurred in North America (north-eastern United States and south-eastern Canada) in 1965, which caused millions of people to become disoriented, paralyzed and even fearful that the end of the world had arrived (117).

In that same chapter the author tried to disclose the density of the referred thesis, how it results from an assemblage of other theses. Taken together with the referred broader ones, they represent the kernel of Anders reflections on the ontology of the machines and apparatus and on the nature of Technology in general.

Let us give them a quick review stressing how they are logically interrelated. The first two, both describing well confirmed trends, work in tandem:

«First thesis: The machines are spreading» (ibid.), ${ }^{20}$

«Second thesis: The expansionist impulse of the machines is insatiable.» (118). ${ }^{21}$

The next three, although apparently contradicting the first two, are indeed to be understood as consequences of them:

"Third thesis: The number of existing machines is declining.»;22

«Fourth thesis: The machines are "in decline".»; (119)23

«Fifth thesis: The machines are being transformed into a single machine.» (120). ${ }^{24}$

Machines, i.e., discrete, independent machines, are being degraded either quantitatively or qualitatively, because they are all becoming «(...) pieces of the apparatus, pieces of larger machines; that is, they become inferior because the dignity of the pieces is inferior to that of the whole of which they form a part» (ibid.). ${ }^{25}$ This is the price they have to pay to fulfil what Anders calls its "dream", "the dream of the machines" ("Der Traum der Maschinen"; see $\S 1$ of chapter 7): to gradually adjust each one another and reach an "ideal" stage in which

\footnotetext{
19 «Im Unterschiede dazu wird hier die These vertreten, daß die Tendenz zum Totalitären zum Wesen der Maschine gehöre und ursprünglich dem Bereiche der Technik entstamme; daß die jeder Maschine als solcher innewohnende Tendenz, die Welt zu überwältigen, die nicht überwältigten Stücke parasitär auszunutzen, mit anderen Maschinen zusammenzuwachsen und mit diesen zusammen als Teile innerhalb einer einzigen Totalmaschine zu funktionieren - daß diese Tendenz die Grundtatsache darstelle (...)».

20 "Erste These: Maschinen expandieren.".

21 "Zweite These: Der Expansionsdrang der Maschinen ist unersättlich.».

22 "Dritte These: Die Zahl der existierenden Maschinen nimmt ab.».

23 "Vierte These: Maschinen "kommen herunter".".

24 "Fünfte These: Die Maschinen werden zu einer einzigen Maschine.»

25 «(...) zu Geräteteilen werden, zu Teilen von Großmaschinen; also deshalb geringer werden, weil die Dignität von Teilen stets geringer ist als die des Ganzen, dem sie zugehören.».
} 
there is only one perfect apparatus, a sort of "utopian Megamachine (or Total Machine)" that encompasses all the apparatuses and at the same time surpasses them all.

The next set of four theses, again, although seemingly counter-intuitive, not to say inconsistent, reveal key aspects of the "inner logic" of techn(olog)ical development:

Sixth thesis: The bigger the machine, the more seriously endangered are its parts, which had operated individually before their merger into the larger machine. (122) ${ }^{26}$

Seventh thesis: Despite the integration of the parts into a whole, the part has to protect itself from the whole just as the whole has to protect itself from all the separate parts: the part, from the breakdown of the whole; and the whole, from the breakdown of the parts. (124) ${ }^{27}$

Eighth thesis: The superior machine, to which the individual machines are annexed in such a way that they only perform as parts of a machine, as long as it functions, must concede to each one of these parts an emergency reserve that must serve them when the superior machine breaks down. (125) 28

Ninth thesis: One of the main tasks for all planning (and this means: of the centralization of thousands of activities and machines, of their orientation towards a single goal) will consist in the future in an evaluation of the optimal size of the superior machine complexes (125-126)29.

The referred 1965 electric grid power failure in North America illustrates well how megastructures like this are remarkably vulnerable, how they are at greater risks due to its dimension, complexity and sophistication (thesis 6) needing to have inbuilt security mechanisms (thesis 7), decentralization of functions (thesis 8) and to be in constant reassessment and readjustment (thesis 9).

Here Anders seemed to have anticipated the possibility of what Paul Virilio called "Integral Accident", revealed in the form of a hazy fear. In fact, the French cultural theorist claimed that "[e]very technology carries its own negativity, which is invented at the same time as technical progress», meaning that «[w] hen you invent the ship, you also invent the shipwreck; when you invent the plane you also invent the plane crash; and when you invent electricity, you invent electrocution...» (1999: 89).

The last thesis has to do with the limits of technology, with the necessity and difficulty of weighing the benefits and harms it generates, and of how this is the hard task the philosopher of technology chiefly has to accomplish; we can condense it as follows:

Tenth thesis: What is characteristic of the current situation of the world is (...) the fact that the inhabitants of the various highly privileged regions are obliged to adopt a totally different position with regard to technology. (127)30

That tendency machines have for expansion and towards totalitarianism is thus a sort of euphemism for saying that technology has proclivity for totalitarianism. Expansionism outdoes the strict technical limits and mobilizes society in its complexity. "World", as Anders says, «(...) is the name for a virtual occupation zone; energy, things, and

\footnotetext{
26 «Sechste These: Je größer die Großmaschine, um so ernster sind ihre Teile gefährdet, die, ehe sie zusammengeschlossen wurden, als Einzelstücke funktioniert hatten.».

27 «(...) siebente These: Trotz der Integration der Teile zum Ganzen muß sich sowohl der Teil vor dem Ganzen wie das Ganze vor den Teilen schützen - der Teil vor dem Versagen des Ganzen, das Ganze vor dem Versagen der Teile.».

28 «Achte These: Der Großapparat, an den die individuellen Apparate so angeschlossen sind, daß sie nur noch die Rolle von Geräteteilen spielen, hat, so lange er funktioniert, jedem dieser Apparatteile eine eiserne Ration mitzugeben, eine Uberbrückungsration, die so lange vorzuhalten hätte, als er, der Großapparat, ausfällt.».

29 «Neunte These: Eine der Hauptaufgaben aller Planungen (und das heißt ja: der Zentralisierung von tausend Aktivitäten und Apparaten, ihrer Ausrichtung auf ein einziges Ziel hin) wird künftig in der Dosierung der Größe von Großmaschinen bestehen.».

30 «Zehnte These: Charakteristisch für den heutigen Zustand der Welt ist (...) daß die Bewohner der verschieden stark begünstigten Regionen zu ganz verschiedener Einstellung gegenüber der Technik verpflichtet sind.».
} 
men are exclusively materials subject to requisition.» (112). ${ }^{31}$, That means that nothing and nobody (things, human beings) can escape being demoted to just feedstock in standing reserve, or, in other terms, everything and everybody is doomed to sooner or later become part of the machinic process, reduced to become a mere mean: «The triumph of the world of machines", says the author, "consists in the fact that the distinction between technical and social structures has been abolished and the distinction between these two spheres has been deprived of its object. (110). ${ }^{32}$

This first industrial revolution, characterised by the replacement of the instrument by the machine, has to be understood as more than just an episode in the history of our modes of production. It has a deeper meaning and a wider scope: extends to the totality of the human world, which now appears as a world of machines; and since there are no isolated machines, the totality is the true machine, the Megamachine. This last is not a means at our disposal, but our world, a world with no outer, a complete immanence for us all.

A second industrial revolution have been overlapping in time with the first. As the machines became more autonomous, man began to lose its central role as a producer (homo faber) and its activities end up sited only at the bounds of the machine system: upstream as mere inventor or simple manual worker and downstream as just a consumer. That means that man got himself at the mercy of an Industry well aware of the double anthropological fact, of man being a being of needs as much as a highly adaptive creature, and fully capable to impose on him a kind of Sisyphean condition of ceaseless consumer.

What seems to be characteristic of this second industrial revolution is the inversion of the relation between needs and goods (products to satisfy the needs): it is not unfulfilled needs that induce the production of goods, but rather these last that create the former. Its most salient characteristic feature is, according to Anders, the instrumentalization of human needs or, in other words, that the main condition for the industrial production system keep growing (in accordance with the technological principle of expansion) or existing is that the field of human needs (limited in nature) never ceases to be artificially enlarged by the manufacture of second order (more or less superfluous) goods.

Anders calls "advertising" the industry specialized in transmuting our natural appetite for goods in an artificial hunger for buyable short-lived goods. It aims the production of goods that once used (as quickly as possible and at an increasingly faster rate) assure the perpetual iteration of their own production. It has, therefore, an ambivalent purpose: to endow the technological artefacts with an ontological status similar to those of natural things and at the same time appeal to their (rapid) destruction, their hasty replacement by more modern and fashionable versions of them. "Every advertisement is an appeal for destruction.» (41) ${ }^{33}$ he said; but immediately added: "Humanity, which treats the world as a world to use and then throw in the trash, also treats its own kind as humanity to use and then throw in the trash.» (42). ${ }^{34}$

\footnotetext{
31 «(...) "Welt” ist mithin der Titel für ein virtuelles Besatzungsgebiet; Energien, Dinge, Menschen sind ausschließlich mögliche Requisitionsmaterialien.».

32 «Der Triumph der Apparatewelt besteht darin, daß er den Unterschied zwischen technischen und gesellschaftlichen Gebilden hinfällig und die Unterscheidung zwischen den beiden gegenstandslos gemacht hat.».

33 «Jede Werbung ist ein Appell zur Zerstörung.».

34 «Die Menschheit, die die Welt als "Wegwerf-Welt" behandelt, behandelt auch sich selbst als "Wegwerf-Menschheit".".
} 
Finally, according to Anders, the third industrial revolution differed from the previous two ones, not by the prolonging of the dominance of instrumental rationality, which had become more and more evident from the mid-19th century to the mid-20th century, but by its total and exclusive ruling.

The historical turning point to this new circumstances, where the means-ends relationship is completely inverted, started to happen around the end of World War II and the beginnings of Cold War. Since then it was no longer the products to have lost the character of ends, as in the $1^{\text {st }}$ industrial revolution, but also man (with his needs) to have been assimilated into the process of production and to have become a means of production.

In fact, it can be said that the world created by the first two industrial revolutions is entirely artificial: a universe of means; a universe, in Anders words, «(...) we are condemned to live in (...)»35 (364) and «(...) there is no longer any act or object that is not a means or that does not have to be a means and whose purpose does not consist in guaranteeing the production or maintenance of other means, which in turn have the purpose of producing or rendering necessary other means, etc.» (ibid.) ${ }^{36}$; a universe after all from where any final ends and everything that is not functionalizable is evacuated or mistrustful.

In contemporary age the production of the means has thus become an end in itself, or, in other words, the means justify the purposes. As the well-known Latin aphorism says "extrema se tangunt" (extremes meet), or, in this case, exploring instrumental reason to its limits (or beyond them) led to transform it into irrationality. To Anders, the invention of the atomic bomb is perhaps the most paradigmatic instance of something produced without need or rational justification, only because the technological means were available. It is also, according to him, an emblematic example of the normative (tyrannical) power Technology have reached and how it caused us to enter an historical final era that unprecedentedly «(...) put humanity in the position of producing its own destruction (...)» (19). ${ }^{37}$

Nevertheless, the transfiguration of man from homo faber into homo creator didn 't just empowered him to produce threatening doomsday machines. It also enabled him to transform himself into raw material, i.e. homo materia (21) or, more generally, to (re)create nature if not ex nihilo at least ex existendo, stirring decisively the natural/artificial boundary and enriching the world with new hybrid entities. Technology has thus given man a God-like power for doing good or doing evil.

With the arrival of the third industrial revolution, as already said, Anders believed we have entered in the last conceivable era for humanity. Beginning to connect the dots, we will analyse hereafter two major consequences of the above mentioned "totalitarianism of the technology" characteristic of this era: (a) the end of work; (b) and the end of History.

\subsection{Work: is its near end in sight?}

\footnotetext{
35 «(...) daß wir dazu verurteilt sind, in einem "Mittel- Universum" zu leben.».

36 «(...) in der es keine Akte o der Gegenstände mehr gibt, die nicht Mittel wären, die nicht Mittel sein sollen, deren Zweck nicht darin bestünde, die Produktion oder Wartung weiterer Mittel zu gewährleisten, weiterer Mittel, deren Zweck wiederum darin besteht, weitere Mittel zu erzeugen oder erforderlich zu machen usw.».

37 «(...) das die Menschheit zum ersten Male dazu instandgesetzt hat, ihren eigenen Untergang zu produzieren (...)».
} 
Work isn `t yet extinct. Far from that. But there is an apparent trend being set in place towards the promotion of its disappearance which can no longer be ignored. Jobs are being destroyed every day and the indicted is automation or, what gives the same, automated machines. These are being charged to have been stealing them aplenty and to continue doing so until none have been left for man.

To understand how we arrived at this situation and if we have good reasons to fear it (and its consequences) it will be helpful to consider some of the thoughts Anders dedicated to announce its coming.

Near the end of his essay (chapter 22: "The obsolescence of space and time") he says:

(...) the function of every technological apparatus consists precisely in being a mediation. This includes the function of technology as a whole. (...) Naturally, this mediating character of technology is undeniable.

But it is likewise undeniable that we invent and utilize machines so that, by their means, we can abbreviate or eliminate that distance, reduce or set aside the impediments that are interposed between need and its fulfilment, between desire and its realization, and that, by their being-in-the-middle, they postpone or impede satisfaction. The mediation of technology attempts to make mediation superfluous. (336-337). ${ }^{38}$

In other words, Anders claims that Technology is at the service of humanity's utopic dream of returning to the immediate and unmediated, that is, to an original pristine paradisiacal state. However, at the same time, and again in a seemingly paradoxical way, he also claims man was made "by his own nature" to work.

What he had seemingly in mind was the restating of the claim that work (particularly that involving real physical effort) has an irreplaceable role in the development of the man `s personality and that if he gets deprived of it, his "voluptas laborandi" (101) he no longer will be able to experience the world, to intervene in it, to transform it and ultimately to create it.

This process of alienation from work begin to happen, according to him, with the rise of the system of industrial production, the introduction of the machine and the division of labour. Those three technologies, the last one in particular (of organizational kind), decisively contributed to make man `s presence (with his labour efforts) increasingly less relevant and more residual in the material and intellectual spheres of production.

To Anders that process evolved gradually: (a) first, preventing the worker from knowing and envisioning how (or even what) the final product in whose manufacturing he participates will exactly be, not to say who will use it, benefit from it, or be a possible victim of it; in short: differently from the artisan in the past the industrial worker remains basically unconscious, or rather blind, about the ultimate goal of his work; (b) second, with the work in automated factories progressively limited to functions of production control, the worker begins to intervene only occasionally, that is, just in circumstances when something was malfunctioning or having failures; (c) eventually man ended deprived of any physical effort, simply waiting for it to appear, in a state of inactivity or odd kind of unemployment.

38 «(...) die Funktion jedes technischen Einzelgerätes gerade in Vermittlung besteht. (...) Dieser Vermittlungscharakter der Technik läßt sich natürlich nicht bestreiten.

Aber ebensowenig läßt sich bestreiten, daß wir die technischen Geräte deshalb erfinden und verwenden, um, eben vermittels dieser, jene Distanz zu verkürzen oder auszulöschen, diejenigen H indernisse zu verkleinern o der auszuräumen, die sich in der Mitte zwischen Bedürfnis und Bedürnnisstillung, zwischen Wunsch und Verwirklichung breitmachen, und die durch dieses ihr In-der-MitteLiegen die Erfüllung verzögern oder verhindern. Was Technik zu vermitteln versucht, ist, die Vermittlung überflüssig zu machen.». 
As Franz Schandl properly summed up in his paper "Arbeit macht nicht frei. Eine kommentierte Zusammenschau zu Günther Anders” (Work will not set you free - Notes on Günther Anders):

Although it may not be apparent at first sight, Günther Anders implicitly supports the analyses of Karl Marx (...) Men conceived as parts appurtenant to the machine and repetitive processes is also precisely the theme addressed by Anders. In Marx value determines itself as "automatic subject". This also means, however, that the value of the commodity known as "labor power" creates automatic subjects in the form of men (2007/2014). ${ }^{39}$

In fact, we may say that Anders didn `t share Marx`s optimism on the supposed liberating effects the automation process will have on the workers, nor on the socially progressive character of Technology. He found that the pervasion of instrumental reason (rationalization) in more and more spheres of life was an unstoppable trend that ultimately will liquidate man as homo faber, replacing his work with the automation of the equipment, or, in short, will make him superfluous, obsolescent.

Nevertheless what seems to worried him the most was not so much the social consequences of massive technological(ly caused) unemployment - a problem that, at least in principle, can be overcome by some piecemeal social engineering - but rather the possible effects it could have on the worker 's psychology or mental health: being condemned to a life of total leisure or complete idleness is being doomed to an empty life. As Anders put it:

The question, "What is to be done?", that the best men of the past century and the beginnings of the 20th century tried to answer, will be replaced by this question: "What do we and our fellow men have to do to keep ourselves busy?" I doubt very much, and indeed refuse to believe, that millions of people can fill the ocean of empty free time with entertainment, "education", sports or sex. And not because I am an intransigent and jealous fanatic of the work ethic (...) What I think is that man cannot live without labor, to which he was once condemned; that he is incapable of entertaining himself around the clock. (98). ${ }^{40}$

\subsection{History: an outdated notion?}

As previously referred, to Anders a major consequence brought by the third industrial revolution was the so-called "end of History". Not in the Hegelian sense that inspired Francis Fukuyama in his widely read essay The End of History and the Last Man: «(...) "the end point of mankind 's ideological evolution" (...)» (1992: ix) and the universalization of Western liberal democracy, after the beginning of the Cold War as, «(...) "the final form of human government" (...)» (ibid.).

The "end of History", according to Anders, coincides with the dawn of Technocracy. In the first page of the second volume of The obsolescence of man he wrote:

By "technocracy" I am not referring to the supremacy of the technocrats (as if they were a group of specialists who dominate contemporary politics), but to the fact that the world in which we

\footnotetext{
39 «Auch wenn es nicht gleich ins Auge springt, schließt Günther Anders implizit an die Analysen von Karl Marx an (...) Menschen als verlängerte Glieder des Maschinellen und Seriellen, das genau ist auch Anders` Thema. Bei Marx wird der Wert als "automatisches Subjekt” gesetzt. Das sagt allerdings auch, dass der Wert der Ware Arbeitskraft automatische Subjekte in Menschenform kreiert.».

40 "Die Frage "Was sollen wir tun?", die die besten Männer des vorigen und angehenden 20. Jahrhunderts zu beantworten versuchten, wird abgelöst werden durch die "Womit sollen wir uns und die Mitmenschen beschäftigen?” Daß die Millionen die ozeanische Leerzeit mit Unterhaltung oder „Bildung" oder Sport oder Sex werden ausfüllen können, das bezweifle und bestreite ich. Und das nicht etwa deshalb, weil ich ein sturer und mißgünstiger Zelot der Arbeitsethik wäre. (...) Aber was ich glaube, ist, daß der Mensch ohne die Arbeit, zu der er nun einmal verflucht ist, nicht leben kann, daß er unfähig ist, around the clock Unterhaltung auszuhalten.».
} 
live and which surrounds us is a technological world, to such an extent that we are no longer permitted to say that, in our historical situation, technology is just one thing that exists among us like other things, but that instead we must say that now, history unfolds in the situation of the world known as the world of "technology" and therefore technology has actually become the subject of history, alongside of which we are merely "co-historical". (9).41

Technology to him is, then, the force that shapes our era in the strong sense of being its creator but also its eventual destructor. He suggested (in the epigraph of chapter 17, The Obsolescence of History I) that that "turning event" was inscribed within the historical process and, therefore, in our destiny much like the "turn to politics" that happened around 1815 (with Napoleon) and "turn to economy" occurred around 1845 (with Marx).

That, he claimed, is «(...) the decisive novelty of our time», i.e., "(...) the fact that, today, technology has become the subject of history» and, therefore, «that we are only cohistorical with that history» (286). ${ }^{42}$

Co-historical, then, means that we are no longer the protagonist of History, «[s]ince now we are all co-historical, regardless of the class to which we belong (...) but rather with another class of history, that is: with the history of the current subject of history, with technology» 289). ${ }^{43}$

The dots of Technology (as totalitarian) and History (as an ended political and economic process) can be here connected. Especially in $\S 5$ ("Technology, the subject of history) of chapter 17 Anders have claimed the two events are coeval, that they start at the same time as if the first have caused the other. He gave the following interpretation for that (the death of the proletarian class and of the utopia embodied in it of emancipation through technological progress, and thus for the rise of super-powerful and ultra-wealthy elite class oppressively ruling the world of tools, machines, devices and apparatuses):

(...) we (...) who live in industrialized countries-have renounced (or have allowed ourselves to be influenced by this renunciation) considering ourselves (as nations, classes, or as humanity) as the subjects of history; we have abdicated (or we have allowed ourselves to be deposed) and we have replaced ourselves with other subjects of history or, more accurately, with a single subject: technology, whose history is not, like that of art or music, just one among other "histories", but the history, or at least it has become the history over the course of recent history, which has been confirmed in the most terrible way by the fact that the existence or nonexistence of humanity hinges on its development and use. (279). ${ }^{44}$

\section{Attempt at a critique}

\footnotetext{
41 «Unter "Technokratie” verstehe ich dabei nicht die Herrschaft von Technokraten (so als wäre es eine Gruppe von Spezialisten, die heute die Politik dominierten), sondern die Tatsache, daß die Welt, in der wir heute leben und die über uns befindet, eine technische ist - was so weit geht, daß wir nicht mehr sagen dürfen, in unserer geschichtlichen Situation gebe es u. a. auch Technik, vielmehr sagen müssen: in dem "Technik" genannten Weltzustand spiele sich nun die Geschichte ab, bzw. Die Technik ist nun zum Subjekt der Geschichte geworden, mit der wir nur noch "mitgeschichtlich" sind.».

42 «(...) die entscheidende Neuigkeit des heutigen Zeitalters», i.e. «(...) die Tatsache, daß heute die Technik das Subjekt der Geschichte geworden ist; daß wir mit dieser Geschichte nur noch "mit-geschichtlich" sind (...)» (286).

${ }^{43}$ Denn "mit-geschichtlich" sind nunmehr wir alle, gleich, welcher Klasse wir angehören ; und das sind wir nicht mehr mit der Geschichte einer anderen Klasse, sondern mit einer anderen Klasse von Geschichte: nämlich mit der Geschichte des heutigen Geschichts-Subjekts: mit der der Technik. (289)

44 «(...) wir (...) daß wir darauf verzichtet haben (oder uns zu diesem Verzicht haben zwingen lassen) uns selbst (oder die Nationen oder die Klassen oder die Menschheit) als die Subjkte der Geschichte zu betrachten, daß wir uns entthront haben (oder haben entthronen lassen) und an unseren Platz andere Subjekte der Geschichte, nein: ein einziges anderes Subjekt gesetzt haben: die Technik, deren Geschichte nicht, wie die der Kunst oder der Musik, eine unter anderen "Geschichten”, sondern nun die Geschichte ist, mindestens die Geschichte im Laufe der jüngsten Geschichte geworden ist - was durch die Tatsache, daß von ihrer Entwicklung und Verwendung (...)».
} 


\section{1. "Obsolescence" as a transcendental}

Mathias Rollot (2015) very insightfully claimed the deep meaning of "obsolescence" lies in being an instance of temporal discontinuity (discontinuité temporelle), of breach in time (rupture dans le temps).

Understood as a token of that category of more or less radical change or essential metamorphosis, the invoked term signals a disturbance in the established order and the coming into being of something other, a novelty.

As Rollot also perceptively pointed out, if the underlying fundamental meaning of the notion is unclear, it is perhaps because the prefix "dis" in dis-continuity remains ambiguous, denoting either a spacing or a disturbance or a negation, and that relative indistinctiveness eventually extends to the idea of obsolescence itself.

In that sense it can be used to speak of Modernity as an inevitable result of the obsolescence of tradition or of Postmodernity as an inexorable outcome of the obsolescence of modernity. Putting it differently: obsolescence will be synonymous of condition of possibility for the emergence of the new (in this case, new eras).

Therefore, the term "obsolescence" refers not only to what no longer is (ce quì n 'est plus), but to «(...)what can no longer be, that which is inadequate, has no more reason to exist (ibid.; 4) 45 ; and conjoined with "Man" - Obsolescence of Man - it effectively depicts the maladjustment of humanity to its world and, more terrifyingly, its anachronism in this new context-environment.

We face today an unprecedented essential tension, pointed out Rollot again, caused by an unbearable "dialectic (dis)continuity" between a subject (Man, Humanity) whose nature hasn 't basically have changed, instead remained unaltered, and a contextenvironment that has been radically transformed by Technology to become Technosphere.

To Anders this is perhaps the most serious challenge a philosopher can meet in nowadays. It is in fact a double challenge: (a) How to find a meaning for our lives in an unheard, unexpected and unthought-of situation where the entire human race may disappear seconds after a nuclear Armageddon have been triggered? How have we to deal with this ongoing scandalous novelty? and (b) How to find a new ethics to manage this new situation, that is, an ethics for the age of Technology, a Technoethics, one able to take the place of the outmoded Aristotelian Nicomachean Ethics.

3.2. "Can imply ought" as a moral imperative.

In the second volume of The obsolescence of Man, more precisely to the end of $\S 4$ in chapter 17 ("Technology as historical subject") with the title "There is no future" (Die Zukunft hat schon geendet), we can find placed between parentheses (suggesting in some way to be negligible) the following thesis: «(...) today - and this defines our epoch -

45 «(...) mais plutôt à ce qui ne peut plus être, ce qui est inadapté, n'a plus de raisons d'être.»- 
technological possibilities are considered to be entirely binding, since facibile faciendum est, that is, what we can do, supposedly we also must do and thus we effectively do it. (278). ${ }^{46}$

Anders explored that thesis in the "Introduction" to his essay - v. § 2 "What can be made must be made" (Das Gekonnte ist das Gesollte) - describing it as «(...) the idée fixe of the third industrial revolution-the possible is generally accepted as the compulsory and what can be done as what must be done.» (17). ${ }^{47}$

In fact, as he promptly added, "[t]oday's moral imperatives arise from technology and render the moral postulates of our ancestors ridiculous (...)» (17). ${ }^{48}$ While the conventional image of morality typically is based on a supposed consensus that there must be moral rules and directions governing the exploitation of the possibilities offered to us by technical progress, Anders, in turn, radically reinterpreting the moral condition, claimed that it is not our moral maxims that are to regulate the use of technological artefacts, but the commandments of the latter to give us the directives for our actions. This means not only that all that is technically possible must be done, but also that what is to be permitted, mandatory or forbidden depends solely on what Technology allows.

A most terrible example he gave to illustrate that claim was the massacre of the Vietnam villagers of My Lai by American Special Forces under the command of Lieutenant William Calley in 1968: the complete extermination of the inhabitants of My Lai, as Lieutenant Calley confessed in court, was pursued through massive helicopter bombing and napalm throwing, not because the GIs (under his command) have been authorized to do that or because it were necessary, but just because it was a possibility they had in their hands they feel compelled to perform or accomplish (291-293).

Examples like that allowed Anders to come to the conclusion (also a thesis) that in this age of Technology the new - and unspoken, at least before him - "categorical imperative" is one which determines Man `s behaviour more cogently than any other known moral law. In his words:

If there were to be a categorical imperative today, it would not refer to our relation with our fellow men or the community or society, but to our relation with the present or future status of technology. And it would sound like this:

Act as if the guiding principle of your action could be that of the machine, a part of which you are or will be;

or, expressed negatively:

Never act in such a way that the guiding principle of your action would contradict the guiding principles of the machines, part of which you are or will be. (289-290). ${ }^{49}$

In other words: Technology became morally compelling at two different but complementary levels: (a) imposing the way we ought to behave; (b) and enforcing us to unceasingly transcend the possible.

\footnotetext{
46 «(...) heute - und das definiert unsere Epoche - technische Möglichkeiten durchweg als verbindlich gelten, weil "facibile faciendum" ist, weil wir, was wir machen können, angeblich auch Machen sollen oder müssen, und deshalb auch effektiv machen. (278)

47 «(...) die fixe Idee der dritten industriellen Revolution - das Mögliche durchweg als das Verbindliche, das Gekonnte durchweg als das Gesollte akzeptiert ist.».

48 «Von der Technik gehen die moralischen Imperative von heute aus; und diese lassen die moralischen Postulate unserer Vorväter (...).» 49 «Wenn es heute einen kategorischen Imperativ gäbe, er würde nicht unser Verhältnis zum Mitmenschen oder zur Gemeinschaft oder zur Gesellschaft betreffen, sondern unser Verhä!tms zum bestehenden oder künftigen Status der Technik. Er würde lauten: "Handle so, daß die Maxime deines Han delns die des Apparats, dessen Teil du bist oder sein wirst, sein könnte" oder negativ: widerspricht".».

"Handle niemals so, daß die Maxime deines Han delns den Maximender Apparate, deren Teil du bist oder sein wirst,
} 
It is more or less irresistible to add some few more general remarks. Philosophers are familiar with what Anders claimed to be the old "Ought implies Can" thesis, aimed at establishing a necessary relation between duties and actions - having a duty would imply the possibility for action - became obsolete in the age where Technology is the subject of History. Kant, for instance, strongly advocates it every time he said that - differently from an obligation that arises out of a set of rules aimed at maintaining some order - an act of duty always stems from moral law.

However, since obsolescence can be also understood as a transcendental, i.e., a condition of possibility for something new take the place of that that became out of use - in this case out of intellectual use - it should constitute no surprise that the best candidate for the purpose is the "Can implies Ought" thesis.

Oddly enough defenders of both theses may concur that, as the well-known Latin motto says, "ad impossibilia nemo tenetur" (nobody is held to the impossible) or that "impossibilium nulla obligation est" (nobody has any obligation to the impossible). But precisely what the "Can implies Ought" thesis states is that we should abide the possible as certainly feasible.

It is «because it forms part of the essence of our technological existence», claimed Anders, «(...) that we not only cannot or are not permitted to refrain from producing what we can (...)»(19-20). 50 We must accept technological advances simply because of their feasibility. Turkish American systems scientist Hasan Özbekhan (1921-2007) wrote in his 1968 seminal paper "The triumph of technology: 'can' implies 'ought." that means and feasibility determines the goals, and that anything that can be done or produced will -indeed should - be done or produced as a matter of need.

But of course, that is what was criticized. Giving just two examples: Ilkka Niiniluoto (1990) in "Should technological imperatives be obeyed?" contended that the principle "Can implies ought “ - all technological possibilities should be carried out - is always conditional on some value premises and therefore invalid; and Hans Lenk (2008) claimed the "ideology of technocratic feasibility" has been overstated and remarked that «[w]hether or not humans are allowed to, or even ought to make, or they can make, apply, produce, initiate, carry through everything they have been able to make or they can make and do in the future, certainly comprises a specific and precarious ethical problem (...)» (50).

\section{References}

Anders, G. (1992). Die Antiquiertheit de Menschen. Bd. 2: Über die Zerstörung des Lebens im Zeitalter der dritten industriellen Revolution (pp. 91-109). 4. Aufl.München: Beck.

dot. 2017. In Merriam-Webster. Retrieved March 8, 2017, from https://www.merriamwebster.com/dictionary/dot

dot. 2017. In Oxford English Dictionary. Retrieved March 8, 2017, from https://en.oxforddictionaries.com/definition/dot

50 «(...) weil es zum Wesen unserer technischen Existenz gehört, daß wir dasjenige, was wir erzeugen können (...)». 
Fukuyama, F. (1992). The End of History and the Last Man. New York: Free Press.

Lenk, H. (2008). The problems of progress: The concept of progress and characteristics of traditional and new technologies. In Wenchao Li \& Hans Poser (Eds.), Ethical Considerations on Today's Science and Technology. A German-Chinese Approach (pp. 4461). Münster: LIT.

Niiniluoto, Ilkka (1990). Should technological imperatives be obeyed? International Studies in Philosophy of Science, 4(2): 181-9.

Özbekhan, Hasan (1968). The Triumph of Technology: "Can" implies "Ought”. In Stanford Anderson (ed.), Planning for Diversity and Choice (pp. 204-219). Cambridge, Mass.: M.I.T. Press. 1968.

Rollot, M. (2015). L’obsolescence, figure de la discontinuité ? Sphères, 3:1-9.

Schandl, F. (2007, December 31) Arbeit macht nicht frei. Eine kommentierte Zusammenschau zu Günther Anders. Available at: http://www.krisis.org/2007/arbeitmacht-nicht-frei (English translation: 2014 January 12. Available at: https://libcom.org/library/work-will-not-set-you-free-notes-g\%C3\%BCnther-anders\%E2\%80\%93-franz-schandl)

Virilio, P. (1999). Politics of the Very Worst. New York: Semiotext(e). 


\section{Blumenberg: Against the Demonization of Technology}

Bernhard Sylla*

I want to propose that Blumenberg's work on technology be read as an expression of deep skepticism against any kind of unilateralism. The term uniliteralism can be understood here as denoting a basic feature of a worldview that has not yet given up hope of arriving at ultimate foundations and which - and I would like to focus on this aspect the most - makes the further mistake of suppressing the opposing side in any dialectic in order to preserve its own side and establish a firm support for further interpretation. This suppression of the opposing side also means that any sort of relationality between the two sides is either entirely effaced or it is expressed in a confused, attenuated form. This relationality and its qualities, i.e. relational properties (or, in Cassirer's terminology: functional terms and functional properties instead of substance terms and substance properties), is thereby rendered inadmissibly fragmented or even completely ignored, leading to a false dogmatism.

To look at things from only one side is blindness. In the philosophy of technology, one form of blindness is the hasty condemnation of the evil specter of technology (Heidegger, Anders, Blumenberg himself in his early writings). But an unreflective technophilia would also be narrow or blind (Kapp, Dessauer, the common-sense belief in the Idea of Progress).

When it comes to the topic of technology, Blumenberg is concerned not only with understanding the grounds for a proper attitude or response towards technology but also with understanding technology itself as an actual phenomenon. A similar picture emerges here, even though the conceptual structure naturally shifts. For here too I take Blumenberg's conviction about the need to overcome unilateralism and recognize bi- or plurilateralism to be an indispensable condition for an understanding of the phenomenon of technology, for a mature understanding that would be able to shed light on the network of complex relations involved in the phenomenon of technology. In various texts Blumenberg goes so far as to call this the task of philosophy (ST 18, 193/94, 202). A first aim of my considerations is to argue for the theses presented above and to show how they can be found in Blumenberg's work.

It is also the case, or so it seems to me, that we have not yet brought to the fore another, complementary aspect of Blumenberg's philosophy of technology. I would argue that it is precisely this aspect, which is especially attractive to situate Blumenberg in the context of Anders - Heidegger - Sloterdijk - Blumenberg. This aspect has to do with what crosses the boundaries of what is known to us, beyond the knowable and the sayable, and which extends from the metaphysical as well as the epistemological, the linguistic, and the

* Centro de Ética, Política e Sociedade, Universidade do Minho, Braga, Portugal. 
ethical point of view to the fundamental questions which never completely lose their grip on us. In my opinion, Blumenberg holds, on the one hand, an extreme, or, as an article in Die Zeit ${ }^{51}$ puts it, a "skeptical skepticism", i.e., a position that can be understood as an antidote against an irrational readiness to engage in radical speculations or dogmatic apocalyptic hysteria. On the other hand, I would argue, Blumenberg is fascinated by metaphysical questions, or, to put it more modestly, he cannot and will not ignore the fact that threads of arguments from the complex force fields of the knowable reach into the realm of the speculative, and that the latter plays a noteworthy contrastive role. In my opinion, the most important points of contact with the basic theses of Anders, Sloterdijk, and Heidegger are to be found here. I will not deal with this last aspect in detail, but only raise it as a question in anticipation of further work.

False unilateralism

False unilateralism can manifest itself in various forms or expressions. A first form, often referred to by Blumenberg, shows itself in a one-sided conception of the dependence relation that obtains between the overly broad and hence vague concepts of mind (Geist) and technology (Technik). Instead of a one-sided dependence, this relation is actually one of reciprocal interaction. This interaction can be expressed in a somewhat broad outline: technology is founded not only on motivations, on the development of ideas, on spiritual causes, but all of these are also supported precisely by technology itself. They are based on a technical-material state of reality, which serves at least in part as the material basis for the history and production of ideas. Blumenberg summed it up in a simple formula (GT 78/79): It is not just about the mind (Geist), which produces technology (Technik), but also about technology (Technik), which produces mind (Geist). The logical structure of this formula not only... but also... - is both, put negatively, vague enough and, put positively, developed enough to serve as the basis for a criticism that reveals the narrow-mindedness of theories that start from unilateral premises. As already mentioned, the first and main error of more limited or narrow-minded theories would be the neglect of the fact that technology also produces the mind rather than strictly just the other way around. According to Blumenberg, it is often overlooked that a certain factual state of material development was a necessary condition for the very origin and development of certain ideas. The invention of the elevator and the telescope can be used as illustrative examples, rendering this premise obvious. As Blumenberg (GT 74) notes, the invention of the elevator, for example, the development of vertical transportation, came about only when there were already high-rise buildings. It can be understood as the result of an attention to certain problems which came to the fore only by the prompting of specific factual circumstances (high-rise buildings) that did not exist before. Likewise, the invention and construction of the telescope is not the result of the desiderata of astronomical research, but of a new technological-material facticity arising from entirely different motivations. It is only when these become a given, a fact, and only because they become a given, that certain ideas can gain a foothold in technological

${ }^{51}$ Nordhofen, Eckhard, “Zum Tode des Philosophen Hans Blumenberg”, in Die Zeit, 12. 4. 1996. 
advancement, and in some cases, such as the telescope, cause a "spiritual-historical leap" (GT 44/45).

When, in the first section (ST 165-171), of his essay "Lifeworld and Technologization according to Phenomenology" ("Lebenswelt und Technisierung unter Aspekten der Phänomenologie"), Blumenberg criticizes two approaches in the philosophy of technology as too short-sighted, he means to correct not only his own earlier position, but also a fundamental shortcoming prevalent in the philosophy of technology of his day. Blumenberg takes two distinct fundamental assumptions to be false or at least too shortsighted: on the one hand, the assumption of an antithesis between nature and technology, on the other, the closely related thesis of the natural technicity of man. Both theses, I would assert, show the basic trait of a false unilateralism. It is wrong, according to Blumenberg, to conceive of technology as the arsenal of manufactured products, machinery, devices, as a "world-of-things/artifacts" ("Dingwelt") or "universe of things/artifacts" ("Universum von Dingen") (ST 165). The error lies in a coarse narrowing of perspective on the phenomenon of technology, since technology is seen in its artifact-character in contrast to non-artificial, natural things. Nature is conceived as the more fundamental, still unadulterated, real principle, as the basis and the forgotten arche of the derivative realm of an artificially produced second nature. Blumenberg notes self-critically in a footnote that this position had been defended in his earlier writings. At least as far as the valuing of the physis-principle is concerned, Blumenberg's critique of this position is directed especially at Heidegger, as well as at any technophobic philosophy which takes the distance to a primordial 'ur'-nature as the basis for a hostility towards the artificial. According to this first theoretical critique, what is unilateral here is an understanding of technology according to which technology plays a purely dissociating and derivative role ultimately always leading back to nature.

The second way in which this view of the phenomenon of technology is narrowminded also has to do, albeit in a different way, with the presupposition of an antithesis between nature and technology, insofar as techne is conceived as a capacity for action, as man's ability to define man via a knowledge that discloses itself in praxis and one which makes techne, as understood above, the prevailing and fundamental basis of a theoretical account of technology. It would be misguided here to look at manufacturing as the essential mark of technology and to think of the specificity of man as homo faber as a prior or even exclusive condition for a theory of technology. Blumenberg has Ernst Kapp particularly in mind. According to Kapp, human history can be fully explained in terms of the history of the development of better tools (ST 165). In my opinion, this is where it starts becoming difficult to understand Blumenberg's critique. Theories in which technology is understood as a capacity of Man for technical production, in which practical forms of knowledge play a decisive role in some way or another, have appeared in very different and, in some cases, widely distinct forms during the twentieth century, so that an adequate and even strongly negative analysis of those theories cannot limit itself to attacking this simple criterion which in fact they all satisfy. I do not wish to assert here that Blumenberg himself has proceeded from the premise that this criterion was full-blooded. I wish only to be cautious, to make Blumenberg's argument stronger than it actually is. For the theoretical focus on the elevation of practical know-how and the production and craft that follows from that know-how could be attributed to those anthropological theories that see humans as deficient beings 
(Mängelwesen), theories in the vein of Herder, Scheler, Gehlen, Plessner, etc., but also, in a certain sense, the theories of Anders, Heidegger, and Sloterdijk. However, the differences between all these different theories would be lost in such a reductive view. I would like to return to this point at the end of my analysis.

As the argument progresses, an argument which Blumenberg presents in "Lifeworld and Technologization according to Phenomenology", the two forms of false unilateralism are, so to speak, gradually revealed. For this purpose, Blumenberg relies on Husserl's concept of lifeworld ("Lebenswelt"). Although Blumenberg distances himself from the transposition of a non-theoretical beginning into the course of history, as attempted by Husserl in several drafts of his The Crisis of European Sciences and Transcendental Phenomenology, he nevertheless appreciates the synchronous meaning of the Husserlian lifeworld, the «always underlying ground layer of life differentiated by different interest gradations» (ST 177) or, in other words, the «universe of self-evidence» (ST 178) or «the inexhaustible supply of unreflective and immediate existing, intimate, and unknown precisely in this intimacy» (ST 178). What Blumenberg appreciates in the late Husserl's understanding of the nature of philosophy, is, if I may say so, this "synchronous" lifeworld concept that is tied to the retrogressive telos of the disclosure qua clarification of self-evident truths, truths which are given to us, just because of their fundamental self-evidence, only in a non-theoretical or pre-theoretical way, and which therefore can only be made reflectively available through theoretical effort. What he rejects as a dogmatic prejudice in the late Husserl is Husserl's obsessive focus on the thesis that the work of understanding of pretheoretical premises in the modern age is always already on the way in the narrow course of scientific interpretation, without the modern man being aware of this. The irony in Blumenberg's critique is that he denounces Husserl's criticism of the unilateralism of his (Husserl's) day, one which is unilaterally influenced by natural science, as unilateral. And that is how we arrived at Blumenberg's own premise. Technology is not a result of an explanation of pre-theoretical certainties, which is reduced to naturalistic thought patterns and therefore both semi-consciously and semi-unconsciously explained, but technology emerges already in advance of science, i.e., in the pre-theoretical area of lifeworld experience and action. In Blumenberg's own words: «But the sentence: The simple experience in which the lifeworld is given is the ultimate basis for all objective knowledge, ${ }^{52}$ is the basic requirement to understand the transformation of the lifeworld into an object-world as itself arising out of the lifeworld and not as a kind of 'original sin' in the form of a voluntary act of the will [the will of the natural sciences; B. S.] which can no longer be investigated.» (ST 183). The bilateralism suggested by Blumenberg consists in placing the reciprocal interplay of the pre-theoretical, the "unknown" factual given, the basic motivations and basic interests on the one hand, and the patterns of models of cognitive interpretation, which are to be found in the complex structure of personal, socio-collective, and epochal dogmatics on the other. This is the precondition for a new theoretical reflection on technology.

The willingness to admit of and engage in reciprocal perspectives - the lifeworld establishes the groundwork for theory, the theory works itself back onto the lifeworld and changes it - does not mean that one is ipso facto automatically protected from all unilateralism, as the example of Husserl shows. Nevertheless, for Blumenberg this

52 Blumenberg cites this sentence from Husserliana VI, p. 229. 
willingness remains the central antidote against premature radicalisms. These radicalisms, in order to develop their dogmatics of alarm, always require an inaccessible moment which, because of its inaccessibility, has a fatal impact. In Husserl, the unilateralism of a scientistic reason plays the part of the unknown and inaccessible crisis factor. Blumenberg, on the other hand, appeals to an attitude, which is skeptical and sober towards every hasty dogmatization. This skepticism can be put into practice in a number of ways. Thus, it is not necessarily disastrous, but in fact quite understandable, that certain research results and discoveries need not be arrived at via a continuous effort, but rather via a crystallized, formulaic form which determines both scientific methodology and daily practice. When I turn on the light switch or use a calculator, I do not necessarily need to be able to have the theoretical knowledge behind it. But that does not necessarily mean being at the mercy of the technical methods of dealing with things, but also the opening up of a room for new and free ideas and transformations in the forcefield of practice (praxis), theory and method. Nor does it mean that theory would be reduced to one definite theoretical methodology, i.e., a particular practice-oriented form of theory. If every such practice-oriented form of theory is recognized and taken seriously in its interwovenness with the lifeworld, then it can also be analyzed and corrected.

The methodological aspects of this needed bilateralism would be further developed in the four years that followed the essay "Lifeworld and Technologization according to Phenomenology", and presented in a clearer fashion in the essay "Methodological Problems of an Intellectual History of Technology" (ST 230-253 / GT 49-86). Methodology is theoretical practice (praxis), and, in the best case, practice, whose theoretical premises are reflectively accessible. If we are to write an intellectual history (Geistesgeschichte) of technology from the unilateral premise that mind is realized in the phenomena of technology, then all that remains for such history to do is ask about the source of motivation (the intellectual (geistige) origins) for putting the ideas into technological practice, or for providing a post factum justification or legitimization of this technological implementation of ideas. Instead Blumenberg suggests:

(...) that the history of facts itself presented as a sequence of facts, thought of in temporal terms, not only 'accompanies' the reflective formation of ideas, but consists of a system of mutuallyrelated effects resulting of the interaction between ideas and reality. It is necessary to see how open the questions here are and also what is to be demanded of the methodology which, by contrast to its precedent, is free from the prejudice of choosing between these alternatives. (GT 54).

According to Blumenberg, one consequence of this openness would be that the questions be asked in a "smaller" (GT 57) way, that is, that the interaction between theory, which is itself practice, and practice, which is theory laden, should not be hidden by assuming large scale premises which are often hastily assumed as foundational, for example, by assuming that practice is always the result of certain previous scientific methods of inquiry.

This suggestion also contains a warning, which I have indicated here with the term "large scale premises". This warning, which could be interpreted as a false bilateralism, should now be briefly discussed. 
Difficulties with bilateralism

In 1961, Blumenberg gave a graduation address at the Justus Liebig University in Gießen entitled "World Images and World Models" ("Weltbilder und Weltmodelle"). The title itself already points to a kind of bilateralism. Blumenberg explains at the beginning of his address how he intended to use these terms:

I must explain these two terms. By "world model" I mean the total representation of the empirical reality as given by the state of the natural sciences and which incorporates the totality of scientific statements. By "world image," I intend to denote the whole concept of reality in which and through which man understands himself, orientates his evaluations and action goals, grasps his possibilities and necessities, and shapes himself according to his essential needs. The world image has "practical power (praktische Kraft)," as Kant would say. (ST 128-129).

As far as the bilateralism of world image and world model is concerned, an intact bilateralism still prevailed until the modern age, although it should be noted that the world image occupied the guiding role:

The world image contained the meaning and, so to speak, the "instruction manual" for all conceivable world models. But this meant at the same time that no adequate understanding could be found within the world model concerning Man's knowledge in itself. Science, having lost sight of the horizon of its own foundations, was unable to be reflectively aware of what it itself was doing. (ST 129)

On this point very close to Husserl, Blumenberg asserts that «the subordination of the world model to the world image is suspended» (ST 131). Not only that, but now the world model has taken over the place of the world image and is sapping the latter of its residual substance completely (ST 131). But here Blumenberg presents a decisive argument, one which brings him into a striking contrast with Husserl. According to Blumenberg, the function of the world image was "monistic" by nature (ST 133), and what ultimately led to the disappearance of a monistic world was the emergence of a plurality of world image surrogates. This historical "disaster (Unfall)" (ST 131) was irrevocable and irreversible. But what made this situation even more difficult was the fact that competition between the world images (or their surrogates) had been imperceptibly dominated by interests from "more commonplace areas (handfesteren Bereichen)" (ST 134). According to Blumenberg, «the discovery of how world images can be misappropriated and used as ideological instruments (...) definitely discredited the representation of the world as world images and made it impossible as a philosophical task» (ST 134). It would be false bilateralism therefore, if we were not to abandon the search for a final monistic world picture, or at least not to abandon the uncritical claim to being able to produce such a picture. This accusation would also have to be made to Husserl, but it likewise serves as an argumentative basis for the rejection of all those philosophers who still thought until the 1960s that such a comprehensively monistic interpretation of our "being-in-the-world" would be achievable. Nevertheless, according to Blumenberg, this does not mean that philosophy remains entirely without a task. 
Philosophy has the task, in a certain way reminiscent of Adorno, of critically reflecting on these interconnections. Furthermore, according to Blumenberg, theoretical insight into these interconnections has the positive function to make us immune to the unilateral temptation (cf. ST 136). A good dose of optimistic confidence lies here in the power of reason not only to resist the seduction of radical monisms, but also in its power to counter the undeniable dangers of an unreflective approach to technological development. This fundamental conviction may very well be regarded as the aspect in which Blumenberg distances himself most clearly from the dark, resigned philosophy of Adorno. The fact that Heidegger is to be counted among one of the main representatives of the radical monists, is something that the Blumenberg of the 1960s leaves no room for doubt, even though Blumenberg had had a quite positive attitude towards Heidegger in the 1950s.53 One of Blumenberg's clearest and most devastating critiques can be read in his 1966's book The Legitimacy of The Modern Age. In it, Blumenberg claims that Heidegger's "pseudo theology"

(...) gets its orientation from both the temporary and provisional status assigned to the age, as prior to a new and then perhaps final event in the "history of Being" - its turning to parousia [presence] - and the compellingly imposed, negative evaluation of the age, in which mythical rejection by the substitute for divinity, on the one hand, and the arrogance of the subjectivity that is a failure as far as "authenticity" is concerned, on the other, make up a single integral state of affairs. The epoch appears as an absolute "fact" [Faktum] - or better: as a "given" [Datum]; it stands, sharply circumscribed, outside any logic, adapted to a state of error, and in spite of its immanent pathos of domination (or precisely on account of it) finally permits only the one attitude that is the sole option that the "history of Being" leaves open to man: submission. The absolutism of "Being" is in truth only the continuation of the medieval result by other means. (LMA 192)

The «stigmata of domination, of the serviceability of theory for technicity, of man's selfproduction» (ibid.) would be read precisely not as a response to an epochal challenge whose outcome is still undecided and which demands the careful vigilance of reason, but rather as the stigmata of an era of «the un-"graced" confusions surrounding the "Being" that has been withdrawn and concealed since the time of the Pre-Socratics.» (ibid.).

Blumenberg's ambivalent philosophical pathos

Until now, I have tried - with the help of the concepts of unilateralism and bilateralism I have introduced - to show the development of a theoretical understanding of the phenomenon of technology as first postulated by Blumenberg in the 1960s. Having made Blumenberg's views explicit, in the next section of my analysis I would like to evaluate this view insofar as it bears some relation to the views of Anders, Heidegger and Sloterdijk.

By entitling this section "Blumenberg's ambivalent philosophical pathos," I implicitly intend to assert the following: From the 1960s onwards, Blumenberg develops a

${ }^{53}$ See, in particular, "The Relationship of Nature and Technology as a Philosophical Problem" (ST 17-29), from 1951, and "Technology and Truth" (ST 42-50), from 1953. In the latter essay there are striking parallels with Heidegger's identification of the first stages of the decadent history of metaphysics. 
sweeping aversion to any theory that essentially espouses any sort of reductive reductionism. If one were to bring the predicate 'fluid' in the sense of Zygmunt Bauman's 'liquid' into play here, one could also understand Blumenberg's anti-radical plea as a strong appeal not to remetaphysicize the fluid in a reductive manner and in a false fear of un-determinateness. Nevertheless, Blumenberg remains highly aware of the attraction, or in Heideggerian terms, of the risk (Wagnis), of borderline thought. These borderline thoughts appear both in positive and negative forms. One should therefore not make of borderline thought a kind of fetish. On the other hand, it cannot be denied that, like every phenomenon lying outside our horizon, the crossing of boundaries exerts a strong attraction. Curiosity (curiositas/cura) ${ }^{54}$, which had always - as Blumenberg masterfully shows in The Legitimacy of the Modern Age- been seen as a threat to willingly surrender to excess, reaches beyond its territorial boundaries into the realm of the insane, the lou-cura, 55 especially if it carries the exciting task of taking on the inherent potential of the "technical" Creator. In short, this means that in Blumenberg there remains a dilemma between a sober and objective endeavor for the nonreduction of complexity and rationality, an anti-dogmatism and anti-ideology, on the one hand, and a preserved sensitivity for the unworkable, the incomprehensible, the unspeakable and its explosive force, on the other. I would now like to briefly present some textual evidence for this thesis, in order to ultimately draw a final and problematizing conclusion.

Sensitivity to the "Dangers" of Technology

There are three weighty objections, that Blumenberg himself invokes, against his reasonably moderate maxim of philosophy as a kind of watchdog. All three arguments come from the camp of the "radical monists".

The first objection claims the following: Technical development naturally acquires a certain momentum and tends to escape human control. This is also due to the fact that technical development does not take place solely on the basis of "endogenous motivations", but is also increasingly a consequence of "exogenous motivations." At first glance this seems to be a thesis that Blumenberg considered only in his early writings, writings such as "Atomic Morality - A Counterpart of the Nuclear Strategy" ("Atommoral - Ein Gegenstück zur Atomstrategie") from 1946, where we find, among other things, the statement that each power potential displays the immanent (and I stress immanent here) tendency to actualize itself qua potential (ST 12). Five years later, in 1951, Blumenberg is already turning against positions that "demonize" technology. Still, he nevertheless affirms as an unmistakable fact that technology is increasingly acquiring characteristics that are threatening to "autonomy," which manifests itself in its «increasing unavailability for man» and in "drowning out his decisions, desires, needs through a dynamics of the object» (ST 18). This fundamental idea

\footnotetext{
54 The close relationship between the two terms (curiositas and cura) is made explicit in The Legitimacy of the Modern Age (see LdN, especially pp. 356 and 404); where Blumenberg considers curiositas to be a specific form of cura.

${ }_{55}$ See LdN 363ff., where the predicate of foolish-insane joins the two other predicates of curiositas, excessiveness and profligacy. The wordplay, that establishes a connection between cura and lou-cura, only works in Spanish (locura) and Portuguese (loucura), and apparently also lacks a sound etymological basis. Still, it seems to me that there is some justification for the connection, in a kind of Heideggerian or Derridarian manner.
} 
also appears repeatedly in later writings. In The Legitimacy of the Modern Age, it is, for example:

But there are phases of objectivization that lose themselves from their original motivation (the science and technology of the later phases of the modern age provide a stupendous example of this!), and to bring them back into their human function, to subject them again to man's purposes in relation to the world, requires an unavoidable counterexertion. (LMA 177)

In "Lifeworld and Technologization according to Phenomenology", Blumenberg speaks of a "pathology of technology," which is, in principle, that the motivation inherent in technology is exogenous, it is "supplied from the outside,» but actually requires an endogenous motivation, which, when the day comes when there is a "global scale desideratum» ("Desiderat in Weltmaßstab»), will have to catch up. One could argue that the last two quotations make it clear that in later writings Blumenberg minimizes the autonomy of technology and characterizes it as ultimately reflectively manageable. This is undoubtedly the case, but we are now, figuratively speaking, faced with a strong headwind brought about by a second objection, one which Blumenberg himself brings into question.

The second objection is found in a particularly pure form in Günther Anders. It expresses the concern of an ever-widening discrepancy between the possibility of reflective control, the reflective or imaginative human capacity, and the dynamic development of the productive capacity. According to Anders, the gap between the rational capacities and the development of technological products becomes unclosable. In 1946 Blumenberg had launched the thesis that «this [the growing advances in atomic technology, B.S.] means an increase, a definiteness, and even an absolute ultimateness of technological autonomy, in such a way that exceeds the possibilities of even the liveliest and most consistent imagination.» (ST 11). Yet seventeen years later, in 1963, in "Lifeworld and Technologization according to Phenomenology," Blumenberg, following Husserl, sketches a scenario according to which the technology implanted in the lifeworld suppresses not only reasonable questioning, but also reasoned reflection and the posing of questions about meaning:

Technologization not only tears apart the foundational context from which theoretical questions emerge in the lifeworld, but it also starts to regulate the lifeworld by levelling all distinctions between that sphere in which we do not yet ask questions and that in which we no longer ask questions, and in which the occupation of this object-space is controlled and motivated by the immanent dynamics of the technically always-already-finished ("Immer-Fertigen"), by the irrefutability of production which is identified with natural power. (ST 190)

Although Blumenberg is encouraged by the hope that reason can overcome this relationship and the inevitability of inaccessibility, the objection as such becomes visible as a kind of negative film on which reason has to work, although the success of this work is by no means guaranteed. The situation is similar when in 1966/67 Blumenberg diagnoses part of the malaise of his era, which is that «today we live in a scientific-technological world with a largely pre-scientific and pre-technological consciousness» (GT 28), which is because we have not yet emerged from the antithesis between nature and technology. Here, too, it is indisputable that Blumenberg hopes that this "emergence" is possible, but it is not 
guaranteed. But Blumenberg's diagnosis of our era is a fact, something that no doubt is true in our space.

The third objection offers as a thesis an idea that is particularly prominent in Anders's work, and which Anders thinks through to its ultimate consequences. Technology becomes an enemy of Man, one that not only competes with human beings but also makes them dependent on itself. In other words, technology makes demands on people, even if these are basically only internalized human demands. The key point here is that Man is not able to see through this logic of internalization. This thesis can be found in its purest and clearest form in a very early text by Blumenberg, "Atomic Morality - A Counterpart of the Nuclear Strategy" 1946:

The qualitative and quantitative progress of technological production, however, leads to the growing differentiation and ultimate separation of the planning and production processes, whereby the clear focus on predefined purposes and intentions, the full insight into the overall structure of individual production is lost. The impulses and demands no longer depend on the human and social prerequisites, but on the technical product in itself, which is strongly supported by the related autonomous structure of the economy. It overturns its servile role, turning Man into the technician, entrepreneur and worker in its (i.e. technology's) service. Indeed, it dictates to the whole of human society the needs and the purposes which are no longer the ones which Man has given himself. (ST 10-11)

Even in this text, Blumenberg makes it clear that despite this diagnosis of the dangers of technological progress, which had also revealed themselves to a terrible extent after the atomic bombs over Hiroshima and Nagasaki in 1946, he rejected the one-sided technophobic demonization of technology (see ST 11). The insight and formulation of this idea, however, does not simply disappear with the Blumenberg of the 1960s, but rather appears again and again in work of this period. In 1957, Blumenberg observes that the physical constitution of Man «is frustratingly unable to meet» the demands imposed on it by «technical work» (ST 95). And in 1963, in "Lifeworld and Technologization according to Phenomenology," Blumenberg tells us that the already finished product in turn imposes needs and meanings, for instance by «artificially creating a whole layer of fictional motives and values, which are themselves created by technical effort» (ST 190). What must be kept in mind is the fact that Blumenberg is by no means blind to those correlations that are at the center of technophobic arguments. Blumenberg does not demonize these correlations, but he notes them and shows that they are to be billed. One could also express the difference as follows: according to Blumenberg, we are not hopelessly at the mercy of these correlations (though this is hardly the case according to a philosophical technophobic), which does not mean that they do not exist. The quasi-paradoxical ambivalence of this mode of reflection lies in the fact that these correlations point at their core to something a fortiori uncontrollable - and the word "uncontrollable" means here that the possibility of control is simply not given nor exists - but which is nevertheless, at bottom, still controllable.

The ambivalence of this specific argument can, I think, be tied to a broader ambivalence present in Blumenbergian reflection, one already stated above: on the one hand, its sober and objective endeavor for rationality and anti-dogmatism, on the other, its sensitivity towards the uncontrollable and that which transcends reason. 
I would now like to show that Blumenberg's aforementioned sensitivity towards the uncontrollable or inconceivable also presents itself in an inverted, positive form. One of Blumenberg's central theses in The Legitimacy of the Modern Age, one which in other writings he explicitly ties to the phenomenon of technology, is that the dissolution of the tight connection between the "God's natural world and Man's world of work (Werkwelt)" and the lack of faith in God as finis omnium naturalium is the "basic presumption of modernity and its essential technicity» (GT 126/127). In an alternative, perhaps more precise, formulation, one can say that at the end of the Middle Ages a technological will first consciously encounters an estranged reality in order to bring about a "new humanity" through the force of technology (GT 33/34).

In many of his texts, Blumenberg now appears to affirm the ancillary thesis that man at the beginning of the modern age is now free to undertake the infinite task of self-assertion and self-definition. This becomes especially clear in "Lifeworld and Technologization according to Phenomenology," when Blumenberg adds his own voice to Husserl's critical commentary. The context is the following: In contrast to Husserl, Blumenberg advocates that we shouldn't stigmatize the mechanization (i.e. a formalization or functionalization) of knowledge as a simple deficiency (since once mechanical knowledge is attained it returns into obscurity), but as a legitimate and necessary tribute, the price that is necessary to pay, if one, like Husserl, dreams of the "realization of the mankind of infinite tasks» (ST 194). Methodization, according to Blumenberg, is enforced by the fact that science in the modern age understands itself as an entity that embodies the "infinite claim[s] of a finite being». Curiositas, formerly condemned as the greatest evil, is now freed from any dogmatic shackles and is thus able to take up defiantly the gulf between infinity and finitude. This is a hallmark of the new, modern technicity (Technizität), which sees lou-cura (madness), as a limit case of cura / curiositas, as an exciting attraction rather than as a mortal sin. In this way, Man is freed to engage in the limitless exploration both of his own potential and of nature. With Francis Bacon, Blumenberg tells, we see the task of «leading the human spirit from what is to what can be» raised «to the task of historical reflection» par excellence (GT 60). This liberation oriented towards the realization of one's own possibilities is closely linked to Blumenberg's understanding of philosophy and technology. As Blumenberg tells us at the beginning of "World Images and World Models", the usefulness of philosophy in history can be summed up in one basic formula: "Philosophy is Man's nascent awareness (Bewusstsein) of himself» (ST 127), and this awareness is the more complete, the more capable it becomes to realize all human possibilities. But it is not simply a matter of theoretical self-assurance, but also an active implementation in practice. Man, as Blumenberg had already stressed in 1953, is not only the being which produces technological structures, but rather «a being that realizes himself technologically, and whose "truth" is fundamentally technological» (ST 49). The publishers of Intellectual History of Technology, Alexander Schmitz and Bernd Stiegler, stress in the book's epilogue, entitled "Editorial Note," that this insight into the nature of human beings as auto-technological beings still or even especially applies to Blumenberg after he had turned towards a moderate 
anti-demonization stance regarding technology. This is because this insight does nothing but draw out the consequences from the bilateral interaction between mind and technology, theory and practice, which is the foundation for Blumenberg's critique of false unilateralism (cf. ST 140/141).

But the fact is, while connecting the auto-technological nature of Man to the still unexhausted, unrecognized and uncontrolled not-yet ("Noch-Nicht"), the reflection on bilateralism as fundamental is nevertheless insufficient to wipe the table clean from both the charms and dangers of this not-yet. That Blumenberg too repeatedly shows himself to be open to the appeal of the speculative and the unanswerable questions, is visible not only at certain stages of his thinking, but is indeed a basic feature of his work. A good example of this is the rather early essay entitled "Imitation of Nature': Toward a Prehistory of Creative Man" ("Nachahmung der Natur' - Zur Vorgeschichte des schöpferischen Menschen"), which culminates in the speculative thesis that particularly in the originating-creative acts of art - and one may very well add the closely related technological creativity - one comes to an ascertainment of the potential of Being, which ultimately becomes a path in which the eternally existent is manifested and revealed in the totality of its possibilities, including its contingencies. Man, and especially the artistic man, as a vehicle for the disclosure of cosmological and ideal potentialities - that is, according to Blumenberg, an idea that underlies the thought of great philosophers like Kant and Leibniz, and great artists such as Paul Klee, an idea whose appeal is quite rationally grounded. It is in my view no contingency, but perhaps a sign of his time, that Blumenberg ultimately assigns to art the role of being a replacement for metaphysics. In the aforementioned article, art is called a "metaphysical activity," namely one that is not committed to any specific dogma, although this thesis can itself be charged with being dogmatic on a meta level. Closely related to this issue are Blumenberg's later works on metaphorology, and this not just because it is there that Blumenberg calls "the loss of metaphysics" a "putting the metaphorical back in its place» (AEMS 144). Rather, the concept of metaphorology in Blumenberg is based on the question of whether the seemingly infinite number of combinations and recombinations of metaphors is a kind of exhaustion of a predefined boundary of potentialities or whether it leaves room for the idea that something completely new could arise from this predetermined material. This question seems to get lost not only in the realm of metaphysical speculation, but it also seems to motivate, in various ways, some of the major technophobic ideas such as those of Heidegger or Derrida. I cannot investigate this question further, but I would now like, in conclusion, to offer some questions and problems that may arise from the analysis I presented.

\section{Concluding Remarks}

The analysis I have presented thus far should, as I have expressed above, show that there is an "ambivalent philosophical pathos" underlying Blumenberg's philosophy. On the one hand, Blumenberg understands, especially from the 60s on, when he embraces antidemonization and begins to trust in the power of reflective reason, that the bilateral interaction of practice and theory is of the utmost importance, especially for an ethical 
assessment of technological progress. This ethic is therefore fluid (or "liquid," using the term introduced by Bauman) because it has to decide on a case-by-case basis, because it has to resort to specific contexts and because it lacks a general and universal metaphysical foundation qua worldview. It would be wrong to interpret this shortcoming as a demonic fatum and so to declare a priori that the enlightening function of reason is bankrupt.

On the other hand, Blumenberg's option to defend anti-demonization does not imply that he denies the existence of the crucial conditions that the "demonologists" point to. That technological advances can escape the control of people, that they are placed at a distance that can hardly be bridged by the human imagination and feeling, that technical objects can present themselves to Man with their own paraethical demands, all of that is stated by Blumenberg, though all of it is seen through the lens of a "hope and trust in reason." Ethical demands for reasonable control, when they take in account real dangers, are fluid because they are located in a boundary area in which the ethical is at risk of saying something only to the most enlightened, while the general public no longer understands the crucial point.

As to Blumenberg's subdued fascination with the full exploitation of human and possibly natural potentialities, there seems to be an understandable sympathy for what Blumenberg himself has worked out as the fundus and engine of modern curiositas: the freedom to pursue these without a bad conscience, even if their opponents continue to peddle the negative anti-image, that of curiositas which slides into madness - lou-cura. I conclude here with a metaphor: The ethics would be fluid here because it dares to enter the 'slippery' terrain of what, due to its indeterminacy and inaccessibility, eludes a sound ethical debate.

The fundamental question that pervades most demonological discourses on technology, is whether man has the capacity to meet the requirements of technological development, or, in other words, whether he lags so hopelessly behind technological development that he can only remediate his increasing inferiority by applying his technological know-how to himself as a species, with the result that he would in fact become something other than what he is. This is a concern Blumenberg cannot really defuse.

Translated by Luís Manuel Pinto de Sá

\section{References}

Blumenberg, Hans (1985). The Legitimacy of the Modern Age. Cambridge, Mass.: MIT Press. [LMA]

Blumenberg, Hans (1997). Die Legitimität der Neuzeit. 3. Aufl., Frankfurt/M.: Suhrkamp [LdN]

Blumenberg, Hans (2009). Geistesgeschichte der Technik. Aus dem Nachlass hrsg. v. Alexander Schmitz und Bernd Stiegler. Frankfurt/M.: Suhrkamp [GT]

Blumenberg, Hans (2015). Schriften zur Technik. Berlin: Suhrkamp [ST]

Nordhofen, Eckhard (1996). Zum Tode des Philosophen Hans Blumenberg, in Die Zeit, 12.

4. 1996 
Bernhard Josef Sylla: Blumenberg: Against the Demonization of Technology

Schmitz, Alexander \& Stiegler, Bernd (2015). Nachwort. In Hans Blumenberg, Geistesgeschichte der Technik. Aus dem Nachlass hrsg. v. Alexander Schmitz und Bernd Stiegler. Frankfurt/M.: Suhrkamp, 137-150 


\title{
Sloterdijk: Da Crítica da Cinética Política à Consciência da Cidadania da Terra
}

\author{
Felizardo António Pedro*
}

Introdução

Neste artigo propusemo-nos a tecer algumas considerações sobre o texto de Peter Sloterdijk A Mobilização Infinita: Para uma Crítica da Cinética Política, publicado, originalmente, em 1989 com o título Eurotaoismus: Zur Kritik der politischen Kinetik, e estabelecer uma ligação com as posições do seu artigo "The Anthropocene: A Process-State on the Edge of Geohistory?”. Vários motivos atiçaram o nosso interesse nos textos: o primeiro, pela presença de uma crítica assente no sujeito histórico o que se enquadra, deste modo, nas discussões da Filosofia da História, nossa área de interesse; segundo, pelas teses sobre o estatuto da técnica na relação com o real, levantando-se, assim, questões tecnoéticas que assentam na relação entre Homem e Natureza, questões que nos têm preocupado nos últimos anos; terceiro, pela proposta do restauro da Natureza através da técnica.

O texto de Sloterdijk A Mobilização Infinita é uma crítica à modernidade como um projeto histórico que jaz num fulcro cinético. Isto pode depreender-se, conforme o autor, nos conceitos cinéticos caraterísticos da modernidade - progressivo e progresso. O conceito progresso, para a modernidade, significa mobilidade para a frente, uma autossuperação, uma ultrapassagem de obstáculos no movimento até atingir o estágio de crescente movimento (Sloterdijk, 2002: 32-33). O substrato do movimento é o sujeito autointensificado, i.e., o sujeito histórico que no seu agir se torna propulsor do movimento. A ação do sujeito histórico consiste no esforço para a construção de espaços ${ }^{56}$ habitáveis dentro do macro-espaço da Terra. No entanto, a Terra oferece limites aos esforços do sujeito pois ela não só é um ecossistema como também é finita.

1. A crítica do movimento ou crítica da cinética política

Se a Crítica da Razão Cínica de Sloterdijk (2011a: 145) visa mostrar a insatisfação com a modernidade como um ser de duplo rosto ${ }^{57}$, propondo o resgate do kinismo; a crítica

\footnotetext{
* Estudante de doutoramento na Universidade Pedagógica de Moçambique; Estágio Científico Avançado na Universidade do Minho Inverno de 2014 a 2015 pela Bolsa da Fundação Gulbenkian.

56 Sloterdijk dedica-se exaustivamente, para além do capítulo III da Mobilização Infinita, ao estudo fenomenológico do ser-no-espaço em sua trilogia Esferas.

${ }^{57}$ Entenda-se, aqui, com Sloterdijk, a dupla moral da modernidade que, a meu ver, é bem expressa pelo binómio conceptual emancipação e violência. Pensadores como Enrique Dussel (1993) expressam tal violência com o conceito de encobrimento do Outro; José P. Castiano
} 
da cinética política, no texto A Mobilização Infinita, tem o propósito de mostrar quanto a modernidade, como projeto histórico, arrastou a humanidade e a Terra para uma situação de crise. Pois, segundo Sloterdijk (2002: 24), a modernidade, enquanto projeto, determinou não só que os acontecimentos passariam a ser tais em conformidade com o pensado pelos homens através dos seus génios e engenheiros, mas também definiu que todo o movimento do mundo deveria passar a ser realizado a partir do plano dos homens. Esta utopia cinética moderna tem a Europa como seu centro. É deste centro geográfico onde sujeitos autointensificados partiram para todo o mundo como missionários da modernidade. Este êxodo missionário ocorreu desde os "descobrimentos".

Ademais, no bojo do plano dos sujeitos modernos não só estava a ideia de fazer história como também a de fazer Natureza. No entanto, Sloterdijk considera que o planificado não veio a correr como tal em virtude das falhas nos cálculos, ou seja, quando se fez a ignição para o movimento primordial pôs-se em marcha o imprevisto, o que não foi contabilizado.

Esta posição dos homens modernos resulta da renegação da aguda perceção prémoderna de que a vida dos homens é um sofrimento e que pouco ou nada pode fazer-se contra o destino. A modernidade caracteriza-se por uma revolta tanto contra o pensamento pré-moderno - enquanto aceitação corajosa do fardo existencial58 - como contra a imprevisibilidade do futuro enquanto destino.

Assim, a modernidade melhor pode ser entendida como revolta, como uma busca de emancipação, um libertar-se dos fardos que a Natureza impõe ao homem. Decorre disto que, para uma melhor perceção deste livrar-se-do-fardo, Sloterdijk defende uma «crítica do serno-mundo a partir de uma analítica do vir-ao-mundo» (2002: 18). Isto para significar que a crítica a fazer deve partir da fase que precede ao nascimento do homem e não apenas da fase pós-natal.

A teoria do fim da história de Fukuyama (1999), por exemplo, parte da fase pósnatal do homem. Aquilo que mobiliza o homem à ação é a vontade tímica de se ver reconhecido por outrem na sua justa medida. Isto originou aquilo a que o autor de O Fim da História e Último Homem chamou por batalha primordial que, não obstante, não teve lugar pois um dos beligerantes resignou-se com o receio de perder a sua vida tornando-se, deste modo, servo e o outro, senhor. O que sucede, por conseguinte, é a dispersão dos horizontes de busca de reconhecimento, sendo que o senhor não encontrando o devido reconhecimento no servo entra em sucessivos ciclos de batalhas com os outros senhores e o servo, por sua vez, busca reconhecimento dominando a Natureza através do cultivo da ciência e da técnica.

Porém, o que se pode interrogar a Fukuyama é como é que após a Revolução Francesa de 1789 (o que denominou de última batalha), não havendo nem senhores nem servos, os homens se uniram para o domínio da Natureza? Isto residiria, para Fukuyama, no facto de que os homens precisam de satisfazer os seus desideratos ou apetites que só o podem ser através da ciência e da técnica.

(2010), filósofo moçambicano, expressa-o com o conceito de violência epistêmica quando desmascara a relação objetificadora das etnociências com os sujeitos epistêmicos africanos.

58 Cfr. Camus (1985). O mito de Sísifo é paradigmático quanto à questão da relação do homem com os vários determinismos sejam naturais sejam sociais. Com Camus a posição do homem a este respeito é expressa pelo conceito revolta caracterizada pela consciência do peso existencial e desprezo pelo destino. Para o moderno, não basta a aceitação, mas importa, sobretudo, a busca tecnológica do alívio ao fardo existencial. 
É possível entender as razões psicopolíticas das diferenças sociais e da mobilização, em Fukuyama, para o progresso sociopolítico dos homens com o escopo nas sociedades de democracia liberal. No entanto, estaríamos ainda no quadro da modernidade como também foi objetivo de Fukuyama ao refundar a história universal.

Com Sloterdijk, poderíamos afirmar que esta perspetiva não elucida os debates sobre a modernidade e a pós-história pois Fukuyama parte do meio do percurso histórico ao propor uma busca do reconhecimento dos homens e não se interrogando sobre os processos cosmogónicos anteriores.

Assim, para Sloterdijk (2002: 18), uma crítica radical deve partir da indagação da "cosmogonia do indivíduo", ou seja, deve debruçar-se sobre o homem no seu "vir à Terra" e no seu esforço para "criar mundos" habitáveis. Portanto, para o autor da Mobilização Infinita, o indivíduo antes de ser homem habitou o seio materno (um mundo intra-uterino) onde os mimos confortaram o seu estar. Assim, o seu nascimento constitui uma rutura com aquele interior que se caracteriza por uma perda de uma série de mimos e confortos para vir a um exterior aberto onde para cá estar é preciso criar mundos que sejam habitáveis. É preciso empreender esforços para a criação desse mundo habitável pois quem passa para o exterior ganha o fardo existencial que o convocará reiteradas vezes para um exercício de libertação.

O nascimento físico do homem é o contrário de um vir-ao-mundo, é um cair para fora de tudo quanto é "conhecido", uma queda no inquietante, um achar-se-exposto numa situação não segura. (Sloterdijk, 2002: 122)

Como se pode notar no excerto, o vir-ao-mundo não é caracterizado apenas pela rutura com os apanágios de conforto proporcionados pelo mundo intra-uterino, mas é, ademais, caracterizado por uma situação completamente diferente onde a inquietude ante o aberto e o inseguro permeia o recém-chegado. Por isso, Sloterdijk (ibidem) aponta para três significados do nascimento do homem: 1. Rutura com o seu mundo intra-uterino, quiçá o único espaço que constitui verdadeiramente uma terra natal; 2. Chegar à incerteza, em virtude de o mundo não ser dado, mas exigir do homem investigá-lo e defini-lo; 3. Chegada precoce imprópria para fazer sucesso ao real, o que causa uma "desorientação, impotência e perplexidade".

Em virtude da rutura da vida intra-uterina e da chegada ao mundo caracterizada pelo inquietante, pela incerteza e insegurança, os habitantes mais antigos socorrem-se de promessas para tranquilizar os recém-chegados. Deste ponto de vista, conforme Sloterdijk (2002: 123), o mundo torna-se "promessa", porém uma promessa "predestinada a ser quebrada" por causa da "instabilidade da situação terrena". Não obstante, os homens agarrados às promessas avançam a todo custo e todo esforço até às últimas consequências no intuito de realizá-las.

Com efeito, dada a rutura com o mundo intra-uterino, o homem se faz tal à medida que empreende esforços para não só trazer-se ao mundo como também para cumprir com a promessa de criação de um mundo confortável semelhante ao do intra-uterino. É a partir do esforço para crescente esforço que se constrói a subjetividade enquanto "esforço-que-soueu”. Eis que, para Sloterdijk (2002: 127), o esforço-que-sou-eu caracteriza-se pelo trazer, 
erguer, manter, isto é, aquele que vem ao mundo faz-se sujeito trazendo-se ao mundo, erguendo-se e mantendo-se através da criação de um mundo habitável.

Deste modo, como o mundo é promessa, o esforço-que-eu-sou tendo-lhe sido prometido o mundo, então torna-se herdeiro da promessa. Daí que, em virtude do sujeito ser o esforço-que-eu-sou e garante das promessas, a história torna-se narração dos esforços do sujeito na tentativa de executar as promessas que fez a si mesmo. É neste âmbito em que se enquadra a modernidade como mobilização através de éticas, políticas cinéticas coadjuvadas pelas filosofias da história; e é dentro deste contexto que o estatuto da técnica pode ser percetível. É a partir destas áreas de saber que o sujeito moderno foi intensificado até à situação em que as coisas se vislumbram, hoje; é uma situação de autêntico matricídio caracterizada pela «campanha de extermínio contra o que está imediatamente presente: o cósmico, o exterior, o diferente» (Sloterdijk, 2002: 245). Disto pode aferir-se a pertinência da busca do tao (caminho) antes de se chegar ao colapso total. O tao, para Sloterdijk, é a desmobilização que pode consistir na desaceleração para efetuar o recuo estratégico para trás ou para as laterais. Mas a possibilidade do recuo para trás ou para a lateral poderia partir do exercício da crítica cinética.

Karl Marx e Friedrich Nietzsche são apontados por Sloterdijk (2002: 50) como importantes referências na teoria crítica do movimento. As suas posições convergem na ideia da "vontade" do sujeito que, para o primeiro, trata-se da «vontade de auto-produção que se apropria a si própria» e, para o segundo, da «vontade de poder enquanto iniciativa para impor uma interpretação do mundo». Pode dizer-se, deste modo, que são a "vontade de auto-produção" e a "vontade de poder" que estão por detrás da redução do real à matériaprima para o suporte das ações históricas. No entanto, para o autor da Mobilização Infinita, a crítica daqueles pensadores permanece no terreno da auto-intensificação do movimento para mais movimento; a crítica marxiana, por exemplo, é mais clara neste sentido.

A teoria crítica de Marx, segundo Sloterdijk, parte da descoberta que a mobilidade do mundo se deve ao movimento do capital que, não obstante, permanece no controlo de poucos indivíduos o que possibilita a acentuação da divisão de classes. Deste modo, para Marx, só uma revolução que se apropria dos meios de produção e do controlo do capital pode permitir, através do incremento da produção e da produtividade, a real emancipação do homem. Pode notar-se que, em Marx, ocorreu a deslocação do polo de propulsão do movimento para o proletariado e não o desvio, nem a desaceleração do movimento, pois para ele a economia sendo a chave de leitura da realidade é com ela e através dela que se pode ultrapassar a questão do conflito de classes. Assim, o proletariado - o sujeito marxista auto-intensificado - repousa no mesmo terreno cinético da modernidade pois herda os conceitos modernos de progresso e progressivo assumindo-os, deste modo, como baluarte da emancipação do homem. Com a apropriação dos meios de produção, o proletariado incrementa a produção e a produtividade o que permite a resolução da grande questão - a da justiça social expressa, conforme Sloterdijk (2002: 40), «na riqueza generalizada e na produtividade ilimitada».

Como se pode notar, a economia, como Marx a concebe na sua crítica, não pode ser a chave para a crítica da modernidade como mobilização pois, segundo Sloterdijk (2002: 49), apesar do "processo económico" ser «certamente o meio mais dócil, o motivo mais 
autoritário e o cúmplice mais multifacetado (...) não passa de apenas um meio para o fenómeno cinético».

Portanto, se o processo económico59 assenta na "acumulação primitiva do capital", então é preciso, defende Sloterdijk, encontrar as raízes estruturais da tal acumulação. Assim, a "acumulação primitiva do capital" encontra suas raízes na "primitiva acumulação da subjetividade" enquanto "primitiva acumulação da energia cinética”. Pode dizer-se, assim, que o processo económico resultante da acumulação primitiva do capital encontra sua razão de ser nas energias cinéticas acumuladas do sujeito.

Para o autor da Crítica Cinética, a relação entre o homem e o mundo pode ser entendida a partir da subjetividade dado que o homem «se destaca do mundo, enquanto primeira natureza, através de iniciativas de índole subjetiva, para sobre esta, que então se torna inteiramente matéria-prima, fonte de energia e suporte», edificar uma segunda natureza. Portanto, para Sloterdijk, a subjetividade é a fonte da auto-mobilização e autointensificação. Por isso, por detrás do mundo mobilizado está o sujeito que através do seu esforço, da sua atividade, auto-mobiliza-se, auto-intensifica-se para suplantar os limites da Natureza e erguer-se, através dela, acima dela. Com efeito, uma crítica que pretenda apreender o atual curso do mundo deverá ser crítica da mobilização, ou seja, "crítica da cinética política" (Sloterdijk, 2002: 51).

A crítica da cinética política, segundo Sloterdijk (2002: 55), é uma «teoria crítica dos tempos modernos, na qual a problemática da supressão das realidades do antigo mundo pela mobilização é descrita em termos de movimento e criticada por meio de exercícios de desmobilização». Se a modernidade é ser-para-o-movimento em resultado do sujeito ser o esforço-que-sou-eu, então os exercícios de desmobilização consistirão no esforço de travagem e recuo ou de movimentos não para frente, mas para os lados (Sloterdijk, 2002: 16).

Desta forma, defende Sloterdijk, a missão da filosofia, nos dias de hoje, devia ser a de ver, refletir sobre o sujeito e os limites dos seus esforços.

Se o rigor ainda tem algum sentido nesta disciplina suspeita, será o de se imaginar entrando na exaltação do esforço mais extremo, a fim de averiguar quais os limites do esforço (Sloterdijk, 2002: 141).

Os sintomas de uma relativa exaustão do sujeito ativo, ou seja, do sujeito moderno, são visíveis nos desafios dos fenómenos quotidianos que, de certa forma, denotam os limites da cinética moderna. O ativo é desafiado pelo passivo pós-moderno que se pode notar, conforme Sloterdijk, nos engarrafamentos dos automóveis em algumas grandes autoestradas da Europa ${ }^{60}$. O sujeito ativo cujo lema é a intensificação dos movimentos é desafiado pela inércia das grandes filas de carros.

Para diagnosticar os limites dos esforços do sujeito, Sloterdijk parte da ideia de Nada de Nietzsche e de Michael Ende. O Nada de Nietzsche significa a negação da vida que se

\footnotetext{
${ }^{59}$ A crítica da mobilização da Natureza entendida a partir do prisma económico, nos nossos dias, é também feita pelo economista francês Serge Latouche com o seu Petit Traité de la Décroissance Sereine (2007) onde por decrescimento entende não a inversão mecânica do crescimento, mas a construção de uma sociedade autónoma, mais sóbria e, sobretudo, mais equilibrada (p. 27).

60 Os engarrafamentos ocorrem também em Moçambique com as longas filas de automóveis usados, isto é, da segunda mão com um grau elevado de poluição como as que caracterizam as primeiras horas das manhãs e o final das tardes de Maputo, a capital moçambicana.
} 
encontra na época moderna pela aliança entre o historicismo e o cristianismo. Assim, para este pensador, escreve Sloterdijk:

A história do Ocidente cristão revela-se como a de um suicídio retardado. Nela, os impulsos negadores da vida penetram todas as formas de pensar, todas as maneiras de sentir, artes e instituições, com uma profundidade que mete medo (Sloterdijk, 2002: 115).

Conforme Sloterdijk, Ende apresenta em A História Interminável um Nada devorador que no seu percurso empalidece e devora tudo à sua volta. Este Nada tão aterrador mostra quanto seriam inúteis os esforços humanos diante da corrente cuja ignição foram, sobremaneira, os homens seus mentores. Tanto o Nada de Nietzsche como o de Ende são tentativas de um diagnóstico dos limites do sujeito. No entanto, defende Sloterdijk, o significado profundo do Nada é melhor apreendido partindo da ideia do vir-ao-mundo.

Como se deu a notar anteriormente, o mundo é promessa cuja efetivação não tem garantia em virtude da própria instabilidade estrutural do real. Nesta ordem de ideias, o Nada significaria, por um lado, a não-promessa de mundo aos recém-chegados e, por outro, a discrepância entre os recém-chegados e as condições de sua chegada, ou seja, o mundo mantém-se tal inseguro, inquietante, pois:

(...) que nada se promete àquele que vem ao mundo, de modo que este também não pode esperar muito da sua existência e, por conseguinte, desenvolve a tendência para voltar donde veio, para o regaço, para a morte, para o todo-nada monista (...) o nada seria, por consequência, uma designação de algum modo exacta para a incongruência notória entre aqueles que chegam ao mundo e as condições de chegada. Essa incongruência torna-se perceptível na medida em que o mundo nada promete aos seus viajantes de chegada ou nada cumpre das suas promessas feitas. O lado inquietante no humano vir-ao-mundo tem o seu fundamento, portanto, na falta de seriedade das promessas humanas (Sloterdijk, 2002: 123).

O Nada identifica-se com a ideia de "vazamento ontológico da subjetividade", usada por Sloterdijk para indicar os limites dos esforços excessivos do ser humano. Neste sentido, após tanto esforço para ereção, o ser humano vê-se apoderado pelo cansaço, extenuam-selhe as forças e é tentado a "voltar" para a Natureza (o que está deitada, o Outro) que é o fundamento do erguer-se (Sloterdijk, 2002: 144). Ora, seria o momento de consciência do fracasso a altura oportuna para os homens pensarem na sua salvação ante a crise provocada pelos excessivos esforços cinéticos que arrastaram consigo o que não devia ter sido arrastado (a Terra e seus ecossistemas)? A nossa salvação, defende o Sloterdijk da Crítica Cinética, só pode ser possível mercê a «um recuo espontâneo da onda da maré cinética "para dentro de nós" (ibidem). E o que foi arrastado indevidamente será que também poderá recuar com o vazar da maré cinética? É na resposta à questão em que Sloterdijk se distancia de algumas das suas posições do texto Mobilização Infinita como pode notar-se nas suas análises ao conceito Antropoceno, o que será objeto de nossa consideração.

2. Da cidadania da Terra 
Como se referiu antes, para Sloterdijk, a filosofia poderá restabelecer a sua pertinência quando, de facto, reabraçar a sua tarefa ginecologista. Esta, segundo Sloterdijk, entende-se não apenas como o exercício de perscrutação de interiores, mas também como acompanhamento dos processos de cosmogonia do sujeito e, ademais, como compreensão e crítica do sujeito enquanto esforço-que-sou-eu que, ao trazer-se ao mundo, procura suplantar o carácter inquietante do mundo e esforça-se por remendar as imperfeições da sua natureza. É no quadro do trazer-se, erguer-se e manter-se no inquietante que é possível entender tanto a modernidade como a relação do Homem com a Terra (ou a Natureza).

A modernidade é um projeto de mobilização dos homens para um constante apartarse da Natureza através da crescente ereção; aliás, os homens em estado de ereção mobilizaram as suas forças de tal modo que a Terra foi também mobilizada. Assim, a modernidade como projeto histórico de mobilização constitui-se no terreno da antisimbiose, isto é, no terreno da autoprodução do homem através da técnica formando uma segunda natureza (a cultura) ${ }^{61}$ que pouco reconhece a sua primeira. Portanto, na sua autoprodução e construção de mundos, os homens modernos reduziram a Natureza a um theatrum cosmopoliticum, isto é, a um palco do acontecer histórico e pura fonte de matériaprima. Foi, precisa Sloterdijk (2002: 230), «pelo processo histórico e pelos seus dois acontecimentos, a alta tecnologia e a missionação dos direitos humanos ${ }^{62}$, que a Terra foi desestabilizada na sua função sustentadora».

Entretanto, estes acontecimentos foram antecedidos pelo casamento de dois sistemas no princípio de realidade da era cristã, a "geopolítica catolizante e o ioga protestante do lucro» que, tendo estabelecido liames entre as "forças terrenas de comércio" e as "motivações sacras", tornaram possível o desenfreio daquilo que Sloterdijk (2002: 231232) chamou panteísmo cinético moderno «que, por meio de capitais, textos, veículos e ondas de rádio, se esforça por conseguir a liquefação total do "duradouro e do permanente"».

O autor da Mobilização Infinita chama atenção para a questão da relativa indiferença dos homens com relação à situação atual da Terra. Este fenómeno releva do facto de que os homens mobilizados ficam atentos aos seus esforços nas ações dramáticas e pouco se interessam pelo estado do seu palco. Só as reiteradas ameaças de ruina do palco - seja através do aumento da temperatura global, cheias ou vendáveis de neve, seja por aparecimento de diversas doenças, isto é, quando se percebe que a Terra perdeu as qualidades de "construtura-sustentadora infinitamente paciente» - tornam possível uma nova auto-perceção dos atores. Assim, para Sloterdijk (2002: 227), só a partir de uma extraversão do ator histórico em relação ao seu palco se vislumbraria a aurora de uma era pós-histórica. A extraversão, aqui, é entendida como «uma dedicação ao que, até agora, foi encarado como mero estrato fundamental».

\footnotetext{
${ }^{61}$ A cultura comporta todo o universo artificial construído pelos homens como o caso das línguas, das máquinas, da ciência, das artes, do Direito. Para Sloterdijk, a autoprodução do homem é graças à técnica. É no estatuto da técnica que encontramos o $1^{\circ}$ e $2^{\circ}$ Sloterdijk. O $1^{\circ}$ Sloterdijk encontra-se na Mobilização Infinita com uma posição quase tecnófoba que imputa a técnica e, fundamentalmente, a maquinização como mentora da crise ecológica; o $2^{\circ}$ Sloterdijk é tecnófilo e lança a sua tese, a título de exemplo, nos artigos "Normas para el Parque humano: Una respuesta a la Carta sobre el Humanismo de Heidegger", "La domesticación del ser: Por uma clarificación del claro" que se encontram, na obra Sin salvación: Tras las huellas de Heidegger (2011b) com o título original Nicht gerettet. Versuche nach Heidegger (2001) e no seu "The Anthropocene: A Process-State on the Edge of Geohistory?" (2015). Nestes artigos, o homem é um ser tecnológico. No entanto, Sloterdijk distingue a técnica que violenta o homem e a natureza (alotécnica) da que coopera com ela (homeotécnica).

62 De modo geral, Sloterdijk compara os sujeitos auto-intensificados com uma bala disparada de uma arma. Napoleão é protótipo de sujeito que, psicopoliticamente motivado, atravessa tudo para levar o novo ideal de humano e seus direitos para o mundo fora.
} 
No entanto, esta dedicação à Terra poderá ser possível, conforme Sloterdijk, desde que, primeiro, o fundamento da crítica transite do eu-sou-para-a-morte para o eu-sou-pornascimento; segundo, aconteça a volta ou a dissidência.

$\mathrm{O}$ eu-sou-para-a-morte constitui o fundamento da metafísica que condiciona o olhar dos homens sobre a existência. Nesta vertente, o eu-sou-para-a-morte oferece à existência humana dois sentidos: o primeiro, o da transitoriedade; o segundo, o de não sentido da própria existência humana no mundo. Tanto a transitoriedade como o não sentido da existência permeia o comportamento do homem que Sloterdijk (2002: 228) chamou cidadão do mundo que se comporta como homo viator, ou seja, aquele para o qual o mundo em que se encontra é apenas um espaço transitório; aliás, como Sloterdijk escreve, "OS cidadãos do mundo mais resolutos já mal vivem nesta Terra - passaram a ser habitantes do país da Complexidade, viajantes da classe grande-vitesse, apressados passageiros em trânsito "neste Hotel da Terra"» (ibidem).

O atual cenário da realidade impõe a superação do eu-sou-para-a-morte através de uma crítica que se funda no eu-sou-por-nascimento. Isto levaria, de acordo com Sloterdijk, a uma consciência de cidadão da Terra com um ethos próprio. O cidadão da Terra rompe com a ideia de que este planeta é apenas um palco e repositório do acontecer histórico e, com efeito, consciente da sua condição ontológica de ser-que-veio-ao-mundo por nascimento, assume a Terra como seu destino. Assim, o cidadão da Terra é empático com o planeta pois com ele forma uma comunidade de fragilidades pelo que, como defende Sloterdijk (2002: 234), a máxima do agir humano «deve, agora, poder levar sempre a que se evitem mais exigências cegas à capacidade da Terra».

Segundo Sloterdijk, as exigências cegas à capacidade da Terra só podem ser evitadas, por um lado, havendo uma Kehre (volta)63; ou, por outro, através de uma dissidência. A volta chega na altura em que os esforços excessivos do agente histórico atingem os seus limites. Com isto, o sujeito reconhece o seu fracasso ao voltar para o amparo daquilo que era seu palco, formando, deste modo, a comunidade de fragilidades, como se referiu acima. Isto comportaria o "vazamento ontológico" da subjetividade entendida como ser-paramovimento que se distende resolutamente para o futuro com o intuito de cumprir as promessas que fez a si próprio para um ser sereno $0^{64}$, mais sóbrio, que toma a precaução como arte contra os esforços erróneos que implicam ações destrutivas. A serenidade, segundo Sloterdijk (2002: 145), «influencia o autorreconhecimento do sujeito que sabe como é ter-se cansado com o impossível».

Não acontecendo a volta, uma outra saída se espelha, como se referiu, a dissidência. Neste ponto, encontra-se o cruzamento entre a crítica da razão cínica com a crítica da razão cinética (crítica da cinética política) em Sloterdijk. A razão cinética mobiliza esforços com o propósito de produzir e caminhar em marés altas de subjetividade. Os esforços mobilizados cooperam para que o sujeito perca a consciência da sua natalidade de tal forma que resoluto declara a si mesmo que para frente é o caminho e é preciso caminhar a toda a velocidade; o importante, desta feita, é a partida e não a chegada. Assim, sem lançar o olhar para trás o esforço-que-eu-sou, na sua forte ereção, caminha com o olhar firme para um utopos que se

${ }^{63}$ Sloterdijk usa o termo Kehre, na esteira de Heidegger, para designar "o relaxamento do sujeito, na sequência das suas distensões autonatais" (2002: 145).

${ }^{64}$ Ser sereno, aqui, lembra-nos o prefácio de Nietzsche no Crepúsculo dos Ídolos onde a serenidade é arte necessária para momentos turbulentos e sombrios. 
pretende topos e perde, deste modo, a sensibilidade para com o topos, onde os seus pés estão assentes.

Para Sloterdijk (2002: 150), "não entrar" tanto na corrente do movimento para mais movimento como na do esforço excessivo pode ser uma saída para a atual situação do mundo. Ora, haveria algum indivíduo, nos nossos dias, que pudesse furtar-se da cinética política globalizante? Houve sempre dissidentes, defende Sloterdijk (ibidem), como Diógenes, que caminham na lateral e na suspeita de tal modo que «não se deixam convencer de que não estão presentes, quando vêm ao mundo (...). Sabem, à sua maneira, o que significa sair para o inquietante»; estes são os dissidentes ou kínicos que, após o sujeito vergar-se sobre si de tanto extenuarem-se-lhe as forças, de tanta humilhação ${ }^{65}$, têm o apanágio de lhe mostrar as evidências da sua derrocada. Na dissidência estão as vozes das «mulheres, crianças, extáticos, pícaros, a gente modesta», convencidas da sua presença no seu vir-ao-mundo.

A Mobilização Infinita de Sloterdijk tem o mérito de ser uma apologia às causas da Terra como um ecossistema cuja saúde depende fundamentalmente da redução da autointensificação do sujeito histórico, pois o movimento impulsionado pela procura do cumprimento das promessas que os homens e as mulheres fazem a si intensifica-os, sobretudo na satisfação das suas necessidades que suplantaram o território do necessário, caindo, desta feita, na híper-satisfação que ignora os limites da Terra. A técnica é mecanismo humano para fazer face ao inquietante e para criar espaços humanos num ecossistema dominado por relações de predação. No entanto, a técnica, ao se acasalar com a economia, levou à prova os limites tanto do sujeito histórico como da Terra.

Não obstante, há que distinguir a partir do modus operandi com relação ao homem e a Natureza, duas espécies de técnica, segundo Sloterdijk. A primeira (alotécnica) é exploradora (do homem e da Natureza) e a segunda (homeotécnica) é cooperativa com o homem e com a Natureza. É a alotécnica, fundada na ignorância, segundo a qual a Natureza é inesgotável e, daí, movida pelos combustíveis fósseis, que levou os homens e a Terra ao novo estágio - o do Antropoceno. Na verdade, para Sloterdijk (2015), trata-se de um estágio de aferição do grau de culpabilidade do homem para a atual crise ecológica e, com efeito, a busca de saídas não apenas condenatórias, conformistas ou fatalistas, mas criativas, pois admite-se que o homem tem uma grande dose de culpa devido à sua psicopolítica de mobilização.

Para o Sloterdijk da Mobilização Infinita, a saída para a crise atual passa pela desmobilização nos movimentos dianteiros e adoção aos movimentos laterais. Mas o que isto significa? O pensamento deste $1^{0}$ Sloterdijk parece-nos não tão claro pois, por um lado, sugere a prossecução da exaltação dos esforços do sujeito até aos seus limites e, por outro, preconiza não só o desvio para a lateral, mas também a não entrada no turbilhão do movimento. Não obstante, está sobejamente claro que da saúde da Terra depende a vida humana, isto é, a prevalência do drama histórico depende da prevalência do palco. E como poderia acontecer isto?

Sloterdijk (2015: 336), socorrendo-se do pensamento de Espinosa, entende que ninguém ainda descobriu o que o corpo da Terra é apto a fazer. Por isso, para além da tese da

${ }^{65}$ Sloterdijk fala em Sin Salvación (2011b: 226) sobre as diversas humilhações ao homem; para além das humilhações das máquinas, o homem sofre a humilhação ecológica que lhe mostra quanto mal interpreta e destrói a longo prazo os ecossistemas ambientais complexos, no entanto, não pode nem os compreender nem os cuidar. 
desmobilização, da sobriedade, da frugalidade no trato com a Terra, o autor defende a abertura de novas possibilidades intentadas, na esteira de Buckminster Fuller, na linha da homeotécnica, pela criatividade das artes, dos engenheiros, da ciência. Ou seja, se ainda há reparos a fazer a mais potencialidades da Terra, tais reparos deverão ser feitos através de uma revolução tecnocientífica. Enfim, para este autor, é preciso dar espaço para a técnica realizar a sua possibilidade de fazer o bem.

De facto, a técnica foi e continuará a ser fator importante na relação entre os homens e destes com a Natureza. Conforme Sloterdijk (2008), ela (a técnica) tornou possível dividir o mundo em duas esferas: a dos ganhadores e a dos perdedores. A esfera dos ganhadores leva metaforicamente o nome de Palácio de Cristal. Este reforça cada vez mais a sua imunidade para não se quebrar a partir de dentro, mas sobretudo para impedir a invasão dos membros da esfera dos perdedores que, vendo a sua imunidade cada vez mais reduzida, vão à procura de alternativas em espaços onde seja possível não só aumentar a sua imunidade, mas também mudar de condição ontológica. Decorre disto que com a técnica, enquanto os ganhadores robustecem interminavelmente a sua imunidade, os perdedores procuram por ela (a técnica) para reconstituir a sua imunidade.

Infelizmente, foi a alotécnica, isto é, a técnica exploradora e nociva ao homem e à Natureza que levou e mantém os ganhadores nos atuais níveis de imunidade mercê à exploração sistemática da imunidade dos perdedores e da Terra. Parece-nos que nos últimos dois séculos da nossa era (Século XX e XXI), apesar de vários esforços de cultivo das técnicas cooperativas com o homem e a Natureza (homeotécnica), há obstinadas lutas em manter as técnicas nocivas e exploradoras. São indícios disso: as múltiplas guerras intermináveis no Congo Democrático, na Somália, no Sudão, na República Centro Africana; as atuais guerras patrocinadas e dirigidas pelos Estados Unidos da América no Afeganistão, no Iraque, na Síria, com o corolário do bombardeamento nas montanhas afegã com a motherbomb americana e as exibições da fatherbomb russa e os reiterados ensaios de mísseis Norte coreanos; e também a recusa do Presidente Trump na assinatura dos Acordos de Paris de 2017 sobre as mudanças climáticas.

Assim, entendemos que, para que a técnica possa realizar o bem almejável (a regeneração do bem da humanidade - a Terra), é preciso resolver o problema da autointensificação do sujeito. Este é o homem que de modo individual e coletivo se autointensifica. Portanto, o problema não está apenas na alotecnicidade da técnica, mas sobretudo no homem que a usa como instrumento.

Concordamos com Sloterdijk que o sujeito é esforço-que-eu-sou, por isso caracterizase pela ofensividade, prontidão combativa, e pelo trauma da sua brevidade existencial e pela esquizofrenia do crescimento económico regulado para as assimetrias. Com isto, somos obrigados a concordar com Byung-Chul Han (2016) que o esforço-que-eu-sou precisa de aprender a "arte da demora", aprender a sentir o "aroma do tempo".

Ora, se é possível concordar com a prossecução do julgamento do homem em virtude do seu poder pastoral desimunologizador no trato com o planeta Terra, como pode ler-se no ensaio sobre o Antropoceno de Sloterdijk, podemos aventar a possibilidade não da condenação do homem, mas da sua reconciliação com a Terra. Esta reconciliação poderia 
partir dos pressupostos da co-subjetividade66 sloterdjkianos coadjuvados com a ontologia reconciliadora ubuntu. Para esta, uma pessoa é porque a (s) outra (s) "é (são) com”, ou ainda, as pessoas são através das outras pessoas. O ser, aqui, não se dissocia do ser-em, do ser-com, do estar-com, ou seja, a ontologia ubuntu é uma ontologia da interdependência. Um alargamento do ubuntuismo67 à esfera da Natureza seria construtivo a partir, em primeiro lugar, da consciência de que Somos através da Natureza e, em segundo, da ideia de que Estamos na Natureza e ela em Nós. Talvez partindo destes pressupostos se possa chegar a uma co-imunidade do Homem e da Natureza que seja menos danosa e que, talvez, seja possibilidade para a definição do modus vivendi et operandi da cidadania da Terra.

\section{Referências}

Camus, A., El mito do Sísifo. Trad. Luis Echávarri. 3ª ed., Madrid: Alianza Editorial, S.A., 1985.

Castiano, J. P., Referenciais da Filosofia Africana - Em busca da Intersubjectivação. Maputo: Ndjira, 2010.

Dussel, E., 1942: O Encobrimento do Outro - A Origem do mito da modernidade. Trad. Jaime A. Clasen. Petrópolis, Rio de Janeiro: Vozes, 1993.

Fukuyama, F., O Fim da História e o Último Homem. $2^{\text {a }}$ ed.. Lisboa: Gradiva, 1999.

Han, Byung-Chul, O Aroma do Tempo - Um Ensaio Filosófico sobre a Arte da Demora. Trad. Miguel Serras Pereira. Lisboa: Relógio D’Água, 2016.

Latouche, S., Pequeno Tratado do Decrescimento Sereno. Trad. Claudia Berliner. São Paulo: WMF Martins Fontes, 2009.

Sloterdijk, P., A Mobilização Infinita - Para uma crítica da Cinética Política. Trad. Paulo Osório de Castro. Lisboa: Relógio D’Água Editores, 2002.

Sloterdijk, P., Esferas III (Espumas) - Esferología plural. Trad. Isidoro Reguera. Madrid: Ediciones Siruela, 2006.

Sloterdijk, P., Palácio de Cristal - Para uma Teoria Filosófica da Globalização. Trad. Manuel Resende. Lisboa: Relógio D’Água Editores, 2008.

Sloterdijk, P., Crítica da Razão Cínica. Trad. Manuel Resende. Lisboa: Relógio D’Água Editores, 2011a.

Sloterdijk, P., Sin Salvación - Tras las huellas de Heidegger. Trad. Joaquín Chamorro Mielke. Madrid: Ediciones Akal, S.A., 2011b.

Sloterdijk, P., Esferas I (Burbujas) Microsferología. Trad. Isidoro Reguera, Ediciones Espanha: Siruela, S.A, 2014a.

\footnotetext{
${ }^{66} \mathrm{Na}$ microesferologia (Esferas I), Sloterdijk defende que o sujeito é sempre resultado de compartilhadas ressonâncias. Sendo assim, 0 sujeito é visto não de forma atomizada, mas na forma molecular, i.e., como co-subjetividade (Sloterdijk, 2014a: 88; 89; 97-98).

${ }^{67}$ Ubuntuismo é uma corrente do pensamento africano que serviu de base para a reconciliação sul africana pós-apartheid. Fazem parte desta corrente de pensamento: Nelson Mandela, Desmond Tutu, Goduka, Ramose, Mkabela e outros. Esta corrente alicerça-se na tese ontológica da relação entre os alteres: we are people through other people.
} 
Sloterdijk, P., Esferas II (Globos) Macroesferología, $3^{\mathrm{a}}$ ed., Trad. Isidoro Reguera, Ediciones Espanha: Siruela, S.A, 2014b.

Sloterdijk, P., "The Anthropocene: A Process-State on the Edge of Geohistory?" In: Davis, Heather and Turpin, Etienne (Eds.), Art in the Anthropocene. Encounters Among Aesthetics, Politics, Environments and Epistemologies. London: Open Humanities Press, 2015. Acessível em: http://openhumanitiespress.org/books/art-in-the-anthropocene. 


